Florida International University FIU Digital Commons

$11-17-2017$

\title{
Selective Sensing of Ions and Ion Pairs of Environmental and Forensic Significance
}

Tosin Mobolaji Jonah

Florida International University, tjona002@fiu.edu

DOI: 10.25148 /etd.FIDC004059

Follow this and additional works at: https://digitalcommons.fiu.edu/etd

Part of the Life Sciences Commons

\section{Recommended Citation}

Jonah, Tosin Mobolaji, "Selective Sensing of Ions and Ion Pairs of Environmental and Forensic Significance" (2017). FIU Electronic Theses and Dissertations. 3498.

https://digitalcommons.fiu.edu/etd/3498

This work is brought to you for free and open access by the University Graduate School at FIU Digital Commons. It has been accepted for inclusion in FIU Electronic Theses and Dissertations by an authorized administrator of FIU Digital Commons. For more information, please contact dcc@fiu.edu. 


\title{
FLORIDA INTERNATIONAL UNIVERSITY
}

Miami, Florida

\section{SELECTIVE SENSING OF IONS AND ION PAIRS OF ENVIRONMENTAL AND FORENSIC SIGNIFICANCE}

\author{
A dissertation submitted in partial fulfillment of the \\ requirements for the degree of \\ DOCTOR OF PHILOSOPHY
}

in

\section{CHEMISTRY}

by

Tosin Mobolaji Jonah 
To: Dean Michael R. Heithaus

College of Arts, Sciences and Education

This dissertation, written by Tosin Mobolaji Jonah, and entitled Selective Sensing of Ions and Ion Pairs of Environmental and Forensic Significance, having been approved in respect to style and intellectual content, is referred to you for judgment.

We have read this dissertation and recommend that it be approved.

José R. Almirall

Bruce R. McCord

Francisco A. Fernandez-Lima

Chenzhong Li

Konstantinos Kavallieratos, Major Professor

Date of Defense: November 17, 2017

The dissertation of Tosin Mobolaji Jonah is approved.

Dean Michael R. Heithaus

College of Arts, Sciences and Education

Andrés G. Gil

Vice President for Research and Economic Development and Dean of the University Graduate School

Florida International University, 2017 
(C) Copyright 2017 by Tosin Mobolaji Jonah

All rights reserved. 


\section{DEDICATION}

I dedicate this dissertation to my family, most especially Tola and Ewaoluwa for all of their love and support. 


\section{ACKNOWLEDGMENTS}

I would like to thank my $\mathrm{PhD}$ advisor, Dr. Konstantinos Kavallieratos for his advice, support and guidance during my $\mathrm{PhD}$ studies. I would like to thank my committee members: Dr. José Almirall, Dr. Bruce McCord, Dr. Francisco Fernandez-Lima, and Dr. Chenzhong Li for providing me with useful feedback during my studies.

I would like to thank all the past and present members of Dr. Kavallieratos's lab. I would also like to thank the University Graduate School for awarding me the Doctoral Evidence Acquisition (DEA) Fellowship Award, which allowed me to collect the data used in this work. I would like to thank the Department of Chemistry \& Biochemistry for providing me funding through teaching assistantships. I would also like to thank my friends: Sauday, Deborah and Olubunmi for all their moral support. I would also want to thank my WOLBM family, without you guys surviving the last two years of my $\mathrm{PhD}$ would have been impossible. You guys are my rock.

Lastly, I would like to express my deepest gratitude to my family, my mother Esther and father Emmanuel Afolabi, and my siblings: Ope, Yemisi, Tobi and Damilare. I thank you all for the advice, support and unconditional love. 


\section{ABSTRACT OF THE DISSERTATION \\ SELECTIVE SENSING OF IONS AND ION PAIRS OF ENVIRONMENTAL AND \\ FORENSIC SIGNIFICANCE.}

by

Tosin Mobolaji Jonah

Florida International University, 2017

Miami, Florida

\section{Professor Konstantinos Kavallieratos, Major Professor}

Dual-host combinations of cation and anion sensors have unique potential for selective detection of ion pairs, such as $\mathrm{NH}_{4} \mathrm{NO}_{3}$, via solvent extraction. Selective sensors for $\mathrm{NH}_{4}{ }^{+}$ and $\mathrm{NO}_{3}{ }^{-}$were synthesized and used together for ion-pair sensing of ammonium nitrate both in organic solvents (using $\mathrm{Bu}_{4} \mathrm{~N}^{+} \mathrm{NO}_{3}{ }^{-}$and $\mathrm{NH}_{4}{ }^{+} \mathrm{PF}_{6}{ }^{-}$) and in extraction of $\mathrm{NH}_{4} \mathrm{NO}_{3}$ from water into dichloromethane. A fluorescent sensor for $\mathrm{NH}_{4}^{+}$based on 1,3,5-triethylbenzene framework shows remarkable binding and sensing selectivity for $\mathrm{NH}_{4}{ }^{+}$vs. $\mathrm{K}^{+}$. Fluorescence and ${ }^{1} \mathrm{H}-\mathrm{NMR}$ titrations reveal surprising differences in sensing properties and binding constants for the tris-(3,5-dimethyl)pyrazole vs. the tris-(3,5diphenyl)pyrazole. X-ray and theoretical DFT studies reveals the role of ion pairing and solvation is revealed by (Chapter 2). We have also demonstrated a unique dual-host extraction-based ion-pair sensing paradigm using Förster Resonance Energy Transfer (FRET), showing selectivity for $\mathrm{NH}_{4} \mathrm{NO}_{3}$. The fluorescence emission of the $\mathrm{NH}_{4}{ }^{+}$sensor tris-(3,5-dimethyl)pyrazole $(305-340 \mathrm{~nm})$, is compatible with the excitation wavelength of the dansyl fluorophore of the nitrate sensor 1,3,5-Tris-(5-dimethylamino-1naphthalenesulfonamido)methyl]-2,4,6-triethylbenzene, thus resulting in FRET emission 
upon combined use of these two sensors for the $\mathrm{NH}_{4} \mathrm{NO}_{3}$ ion pair. Contact of dichloromethane solutions containing the two hosts with aqueous solutions of $\mathrm{NH}_{4} \mathrm{NO}_{3}(1$ $\mathrm{x} 10^{-5} \mathrm{M}$ to $1 \times 10^{-4} \mathrm{M}$ ), resulted in FRET fluorescence enhancements at $510 \mathrm{~nm}$, with increasing concentrations of $\mathrm{NH}_{4} \mathrm{NO}_{3}$, while $\mathrm{NaNO}_{3}, \mathrm{KNO}_{3}, \mathrm{NaCl}$ and $\mathrm{KCl}$ showed only minimal fluorescence responses, under identical conditions (Chapter 3). The ability of the tris-pyrazole framework to bind cations, such as $\mathrm{NH}_{4}{ }^{+}$, was also exploited in a detailed fluorescence and ${ }^{1} \mathrm{H}-\mathrm{NMR} \operatorname{Ln}(\mathrm{III})$ binding study using tris-pyrazole ligands with varying substitution patterns. The dependence of fluorescence responses on pyrazole substitution that had been observed for $\mathrm{NH}_{4}{ }^{+}$(Chapter 2), was also observed for several $\mathrm{Ln}$ (III), indicating the significant role of ion pairing for $\operatorname{Ln}(\mathrm{III})$ binding and fluorescence sensing (Chapter 4). These findings can lead to new selective Lanthanide (Ln) and Actinide (An) extractants and sensors, which are important for nuclear separation and extraction processes and detection of fission products. Likewise, the tris-dansyl nitrate receptor (Chapter 3) was also found to be an efficient $\mathrm{Hg}$ (II) fluorescent sensor, in its deprotonated form, showing fluorescence quenching, with no responses for $\mathrm{Ca}(\mathrm{II}), \mathrm{Ag}(\mathrm{I}), \mathrm{Co}(\mathrm{II}), \mathrm{Cu}(\mathrm{II})$, and $\mathrm{Cd}(\mathrm{II})$, and a fluorescence enhancement for $\mathrm{Zn}$ (II). The responses to $\mathrm{Hg}$ (II) were also observed in the presence of those competing cations, in competitive titration experiments. An X-ray crystal structure showed the ability of this receptor in its trianionic version to bind three $\mathrm{Hg}(\mathrm{II})$ atoms, also containing three $\mathrm{CH}_{3} \mathrm{COO}^{-}$counteranions. The X-ray crystal structure of the same receptor with $\mathrm{HgCl}_{2}$ showed instead a 2:1 complexation pattern, with one $\mathrm{Hg}$ atom complexed by two bis-deprotonated receptor molecules (Chapter 5). 


\section{TABLE OF CONTENTS}

CHAPTER

PAGE

I. A Review: Ion pair receptors and fluorescence sensing $\ldots \ldots \ldots \ldots \ldots \ldots \ldots \ldots 1$

1.1. Ion pair sensing.......................................... 2

1.2. Ion pair receptors......................................2

1.3. Ditopic ion pair receptors................................4

1.3.1. Ditopic receptors based on spatially separated ion...........................4

1.3.2. Ditopic Receptors based on contact ion pairs..................................6

1.4. Dual-host ion pair receptors...............................8

1.5. Ion-pair receptors as sensors.............................. 10

1.6. Ion pair extraction...................................... 12

1.7. Solvation effects in ion pairing.............................. 13

1.8. Fluorescence sensors....................................14

1.8.1. The charge transfer processes..........15

1.8.2. Photoinduced electron transfer (PET)....16

1.8.3. Electronic energy transfer (EET).......17

1.9. Methodology for quantifying supramolecular interactions .....18

1.10. Overview of $\mathrm{NH}_{4}{ }^{+}$receptors.............................21

1.11. Overview of nitrate receptors...........................23

1.12. Overview of mercury (II) sensors.......................25

1.13. Overview of lanthanide receptors........................26

1.14. References..........................................27

II. Remarkably selective $\mathrm{NH}_{4}{ }^{+}$binding and fluorescence sensing by tripodal tris(pyrazolyl) receptors derived from 1,3,5-triethylbenzene.................38

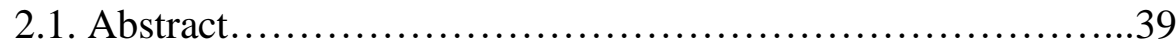

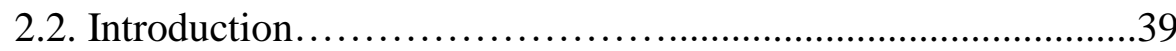

2.3. Results and discussion..................................41

2.4. Conclusion..............................................47

2.5. Experimental...........................................48

2.6. References............................................. 72

III. Selective ion-pair fluorescent sensing of ammonium nitrate by a combination of pyrazolyl and dansyl tripodal extractants...................76

3.1.Abstract..................................................... 77

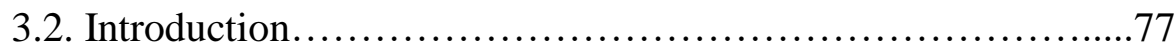

3.3. Results and discussion..................................... 80

3.4. Conclusion...............................................90

3.5. Experimental............................................ 90

3.6. References..........................................93 
IV. Tripodal pyrazole ligands and analogs for selective $\mathrm{Ln}(\mathrm{III})$ sensing..........96

4.1. Abstract..............................................97

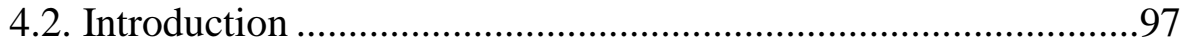

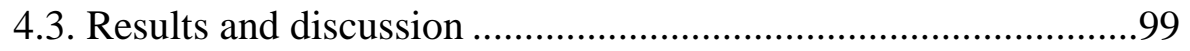

4.4. Conclusion ...............................................................110

4.5. Experimental ............................................................ 110

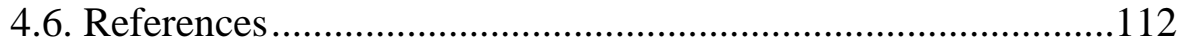

V. $\quad \mathrm{Hg}(\mathrm{II})$ complexation and sensing by a tris-dansylamide derivative of 1,3,5-Tris(2-aminomethyl) -2,4,6-triethylbenzene...................... 114

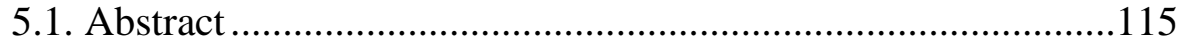

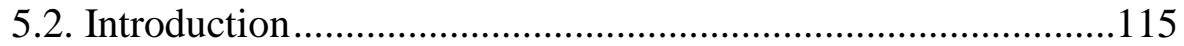

5.3. Results and discussion ......................................................117

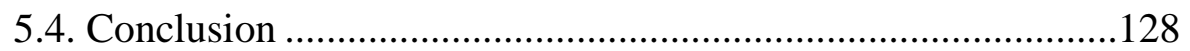

5.5. Experimental ................................................................ 129

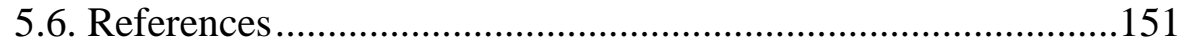

VI. General Conclusion............................................... 154

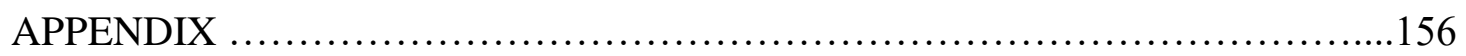

VITA..................................................................... 170 
2.1. Average distances (in $\AA$ ) and corresponding standard deviations.............53

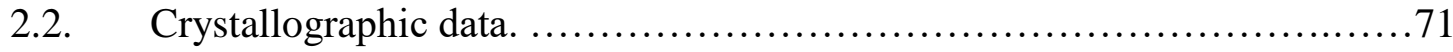

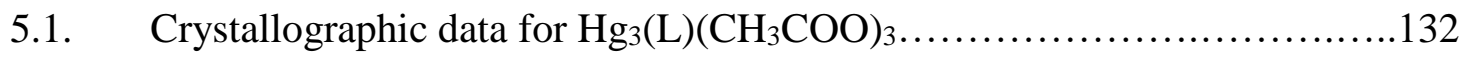

5.2. Fractional atomic coordinates $\left(\times 10^{4}\right)$ and equivalent isotropic displacements parameters $\left(\AA^{2} \times 10^{3}\right)$ for $\mathrm{Hg}_{3}(\mathrm{~L})\left(\mathrm{CH}_{3} \mathrm{COO}\right)_{3}$. $\mathrm{U}_{\mathrm{eq}}$ is

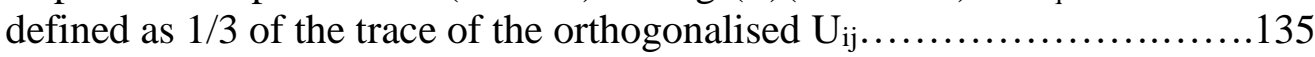

5.3. Anisotropic displacement parameters $\left(\times 10^{4}\right) \mathrm{Hg}_{3}(\mathrm{~L})\left(\mathrm{CH}_{3} \mathrm{COO}\right)_{3}$. The anisotropic displacement factor exponent takes the form: $-2 \pi^{2}\left[h^{2} a^{* 2} \times U_{11}+\ldots+2 h k a * \times b^{*} \times U_{12}\right]$

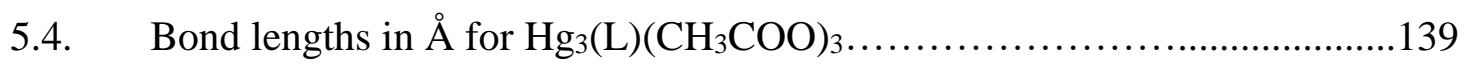

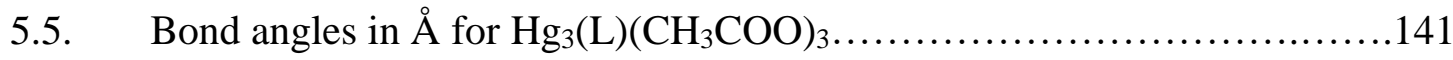

5.6. Hydrogen fractional atomic coordinates $\left(\times 10^{4}\right)$ and equivalent isotropic displacement parameters $\left(\AA^{2} \times 10^{3}\right)$ for $\mathrm{Hg}_{3}(\mathrm{~L})\left(\mathrm{CH}_{3} \mathrm{COO}\right)_{3}$. $\mathrm{U}_{\mathrm{eq}}$ is defined as $1 / 3$ of the trace of the orthogonalised $\mathrm{U}_{\mathrm{ij}}$

5.7. Atomic occupancies for all atoms that are not fully occupied in $\mathrm{Hg}_{3}(\mathrm{~L})\left(\mathrm{CH}_{3} \mathrm{COO}\right)_{3}$

5.8. Crystal data and structure refinement for $\left[\mathrm{Hg}\left(\mathbf{L} . \mathrm{H}_{2}\right)_{2}\left(\mathrm{H}_{2} \mathrm{O}\right)\right] \ldots \ldots \ldots \ldots \ldots \ldots 148$

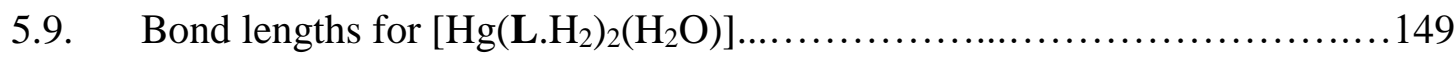

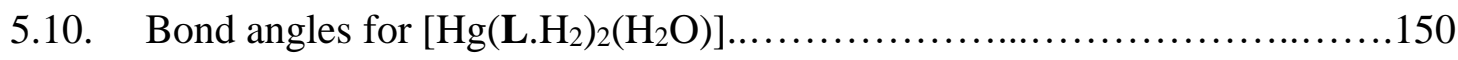

A.1. Hydrogen bond information for RGR534_a.............................165 
1.1 Structure of crown ether-type ditopic receptors $1^{22}$ and $2^{14}$

1.2 Structure of alkylammonium chloride ion pair receptor 3 reported by

Gellman et al. ${ }^{23}$.

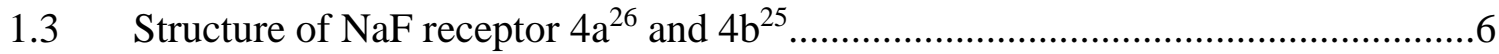

1.4 Structure of ion pair receptor 5 reported by Reinhoudt that binds $\mathrm{NaCl}$..........6

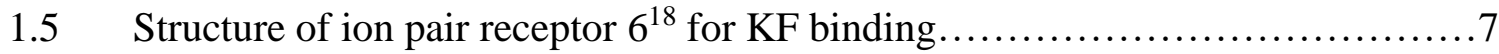

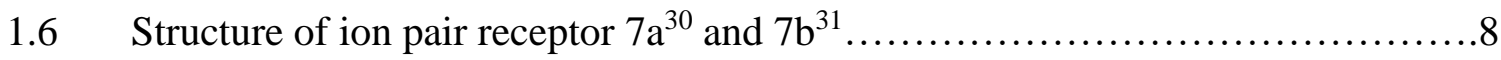

1.7 Structure of dual-host ion pair receptors reported by Das and his group. ...............9

1.8 Structure of 18-crown-6 and calix[6]pyrrole receptors for effective binding of

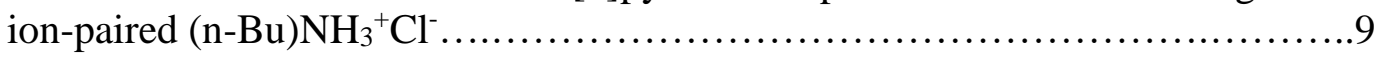

1.9 Structures of 18-crown-6, tripodal amide and the single crystal structure of the encapsulated $\mathrm{F}^{-}$in the cavity of the tripodal amide ${ }^{34} \ldots \ldots \ldots \ldots \ldots \ldots \ldots . . . \ldots 10$

1.10 Structure of ferrocene-based amidopyridine receptor 10 reported by Tucker et al...............................................................

1.11 Structure of ferrocene/imidazopyrene receptor ${ }^{37} 11$ reported by

Molina et al.

1.12 Structure of ferrocene/imidazopyrene receptor 12 reported by

De Silva et al. ${ }^{38}$

1.13 Metal sulfate binding with a salen-based receptor reported by

Tasker $^{42}$

1.14 An all-organic internal charge transfer (ICT) based fluorescent sensor...........16

1.15 A twisted internal charge transfer (TICT) based fluorescent sensor...............16

1.16 A metal-to-ligand charge transfer (MLCT) based fluorescent sensor.............16

1.17 Photoinduced electron transfer (PET)-based fluorescent sensors.................17 
1.18 Calix[4]arene-based electronic energy transfer (EET)-based

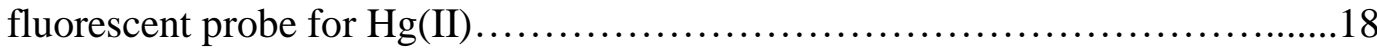

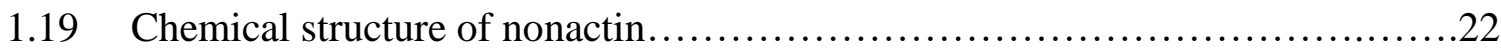

1.20 The cage-type $\mathrm{NH}_{4}{ }^{+}$receptor reported by Kim et al. based on cation $-\pi$ interaction and hydrogen bonding ${ }^{63}$

1.21 A fluorescent probe bearing a diazostilbene chromophore and a benzo-15-crown-5 ether moiety reported by Bekiari et al.

1.22 A tripodal N-anthracen-9-ylmethyl-N7,N7-bis-[2-(anthracen-9-ylmethylthiophen-2-ylmethylamino)ethyl]-N- thiophen-2-ylmethyl-ethane with selective fluorescence enhancement for $\mathrm{Ce}^{3+}$ in dry tetrahydrofuran (THF) reported by Aoki et al.

2.1 Chemical structure of ligands 1 and 2

2.2 Fluorescence titration $\left(\lambda_{\mathrm{exc}}=272 \mathrm{~nm}\right)$ of $1\left(1.0 \times 10^{-4} \mathrm{M}\right)$ with $\mathrm{NH}_{4}{ }^{+} \mathrm{PF}_{6}{ }^{-}$or $\mathrm{K}^{+} \mathrm{PF}_{6}{ }^{-}$in $\mathrm{CH}_{3} \mathrm{CN} / \mathrm{CH}_{2} \mathrm{Cl}_{2}(1: 1)$.

2.3 Fluorescence titration $\left(\lambda_{\text {exc }}=262 \mathrm{~nm}\right)$ of 2 with $\mathrm{NH}_{4}{ }^{+} \mathrm{PF}_{6}{ }^{-}$in $\mathrm{CH}_{3} \mathrm{CN} / \mathrm{CH}_{2} \mathrm{Cl}_{2}(1: 1)$

$2.4 \quad{ }^{1} \mathrm{H}-\mathrm{NMR}$ titration plot of 1 (for $\mathrm{C}_{3} \mathrm{CH}_{2}$ ) with $\mathrm{M}^{+} \mathrm{PF}_{6}^{-}\left(\mathrm{M}^{+}=\mathrm{NH}_{4}^{+}, \mathrm{K}^{+}\right)$in acetone- $\mathrm{d}_{6}$. The concentration of 1 was kept constant at $2 \mathrm{mM}$

$2.5{ }^{1} \mathrm{H}-\mathrm{NMR}$ titration of 1 with $\mathrm{M}^{+} \mathrm{PF}_{6}{ }_{6}^{-}$in $\mathrm{CD}_{3} \mathrm{OD}\left(\mathrm{X}=\mathrm{NH}_{4}^{+}, \mathrm{Na}^{+}\right.$, or $\left.\mathrm{K}^{+}\right)$. The concentration of 1 was kept constant at $2 \mathrm{mM}$

2.6 Jobs plot of $1\left(\mathrm{CH}_{3} \mathrm{CH}_{2}-\right)$ with $\mathrm{NH}_{4}{ }^{+} \mathrm{PF}_{6}{ }^{-}$in acetone- $\mathrm{d}_{6}$. $0.002 \mathrm{M}$ Stock solutions of 1 and $\mathrm{NH}_{4}{ }^{+} \mathrm{PF}_{6}{ }^{-}$were used.

2.7 Jobs plot for 2 with $\mathrm{NH}_{4}{ }^{+} \mathrm{PF}_{6}{ }^{-}$in acetone- $\mathrm{d}_{6} .0 .002 \mathrm{M}$ Stock solutions of 2 and $\mathrm{NH}_{4}^{+} \mathrm{PF}_{6}^{-}$were used.

2.8 Crystal structure of [2] (left) and $\left[2 \cdot \mathrm{NH}_{4}\right]^{+} \mathrm{PF}_{6}{ }^{-}$(right). H-atoms and disorders on phenyl rings are not shown for clarity....

2.9 Crystal structure of $\left[2 \cdot \mathrm{NH}_{4}\right]^{+} \mathrm{PF}_{6}{ }^{-}$showing $\mathrm{NH}_{4}{ }^{+} \mathrm{H}$-bonded to the 2 host. $\mathrm{N}(\mathrm{pz}) \cdots \mathrm{N}\left(\mathrm{NH}_{4}\right)$ distance: $2.950(3) \AA$. The disordered $\mathrm{PF}_{6}{ }^{-}$is not shown for clarity .46

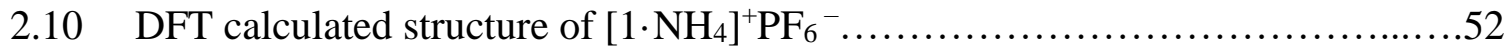




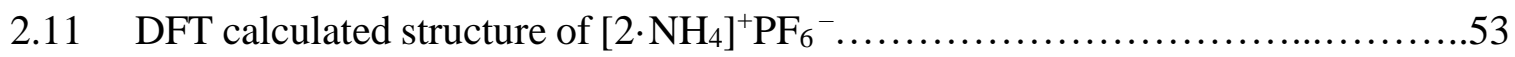

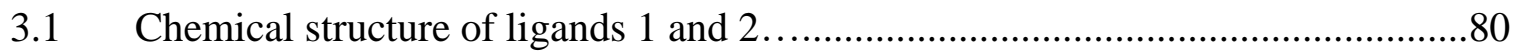

$3.2{ }^{1} \mathrm{H}-\mathrm{NMR}$ titration of 2 with $(\mathrm{n}-\mathrm{Bu})_{4} \mathrm{~N}^{+} \mathrm{NO}_{3}{ }^{-}$in $\mathrm{CDCl}_{2}$. The concentration of 2 was kept constant at $2 \mathrm{mM}$

3.3 Fluorescence titration $\left(\lambda_{\text {exc }}=352 \mathrm{~nm}\right)$ of $2\left(1.0 \times 10^{-6} \mathrm{M}\right)$ with $\left(1.0 \times 10^{-3} \mathrm{M}\right)$ of $(\mathrm{n}-\mathrm{Bu})_{4} \mathrm{~N}^{+} \mathrm{NO}_{3}^{-}$in $\mathrm{CH}_{2} \mathrm{Cl}_{2}$. The concentration of 2 was kept constant.

3.4 Fluorescence emission of an equimolar mixture of 1 and 2 $\left(5.0 \times 10^{-5} \mathrm{M}\right)$ with an equimolar mixture of $\mathrm{NH}_{4}{ }^{+} \mathrm{PF}_{6}{ }^{-}$and (n-Bu) ${ }_{4} \mathrm{~N}^{+} \mathrm{NO}_{3}{ }^{-}$in $\mathrm{CH}_{3} \mathrm{OH} / \mathrm{CH}_{2} \mathrm{Cl}_{2}(2: 8)$...

3.5 Fluorescence titration curve of $1 \& 2$ with $\mathrm{NH}_{4}{ }^{+} \mathrm{PF}_{6}{ }^{-} \&(\mathrm{n}-\mathrm{Bu})_{4} \mathrm{~N}^{+} \mathrm{NO}_{3}{ }^{-}$ $\lambda_{\text {exc }}=272 \mathrm{~nm}, \lambda_{\mathrm{em}}=352 \mathrm{~nm}$. .84

3.6 Fluorescence emission $\left(\lambda_{\text {exc }}=272 \mathrm{~nm}\right)$ of an organic phase $\left(\mathrm{CH}_{2} \mathrm{Cl}_{2}\right)$ containing $1 \& 2(0.05 \mathrm{mM})$ after extraction with $\mathrm{NH}_{4} \mathrm{NO}_{3} . \mathrm{NH}_{4} \mathrm{NO}_{3}$ concentrations are $0 \mathrm{mM}$ (black), $0.01 \mathrm{mM}$ (red), $0.05 \mathrm{mM}$ (blue) and $0.1 \mathrm{mM}$ (green)

3.7 Fluorescence emission of $1 \& 2(0.05 \mathrm{mM})$ after extraction with $\mathrm{KNO}_{3}$ from water into $\mathrm{CH}_{2} \mathrm{Cl}_{2}$ following $272 \mathrm{~nm}$ excitation.

3.8 Fluorescence emission of $1 \& 2(0.05 \mathrm{mM})$ after extraction with $\mathrm{NaNO}_{3}$. Concentration range of $0 \mathrm{mM}-0.10 \mathrm{mM}$ in $\mathrm{CH}_{2} \mathrm{Cl}_{2}$ following $272 \mathrm{~nm}$ excitation. 86

3.9 Fluorescence emission of $1 \& 2(0.05 \mathrm{mM})$ after extraction with $\mathrm{KCl}$ in $\mathrm{CH}_{2} \mathrm{Cl}_{2}$ following $272 \mathrm{~nm}$ excitation

3.10 Fluorescence emission of $1 \& 2(0.05 \mathrm{mM})$ after extraction with $\mathrm{NaCl}$ in $\mathrm{CH}_{2} \mathrm{Cl}_{2}$ following $272 \mathrm{~nm}$ excitation

3.11. Fluorescence emission $\left(\lambda_{\text {exc }}=272 \mathrm{~nm}\right)$ of organic phases $\left(\mathrm{CH}_{2} \mathrm{Cl}_{2}\right)$ containing $1 \& 2(0.05 \mathrm{mM})$ after extraction with various concentrations of $\mathrm{MNO}_{3}\left(\mathrm{M}=\mathrm{NH}_{4}{ }^{+}, \mathrm{K}^{+}\right)$showing selective FRET sensing for $\mathrm{NH}_{4} \mathrm{NO}_{3}$ .88

3.12. Fluorescence emission $\left(\lambda_{\text {exc }}=272 \mathrm{~nm}\right)$ of organic phases $\left(\mathrm{CH}_{2} \mathrm{Cl}_{2}\right)$ containing $1 \& 2(0.05 \mathrm{mM})$ after extraction with various concentrations of $\mathrm{NH}_{4} \mathrm{NO}_{3}$ and $\mathrm{KCl}$, showing selective FRET sensing for $\mathrm{NH}_{4} \mathrm{NO}_{3}$ 
3.13 Fluorescence emission $\left(\lambda_{\mathrm{exc}}=272 \mathrm{~nm}\right)$ of organic phases

$\left(\mathrm{CH}_{2} \mathrm{Cl}_{2}\right)$ containing $1 \& 2(0.05 \mathrm{mM})$ after extraction with various concentrations of $\mathrm{NH}_{4} \mathrm{NO}_{3}$ and $\mathrm{NaCl}$...

4.1 Fluorescence emission for receptor $1\left(\lambda_{\mathrm{exc}}=272 \mathrm{~nm}\right)$ and $2\left(\lambda_{\mathrm{exc}}=262 \mathrm{~nm}\right)$ in

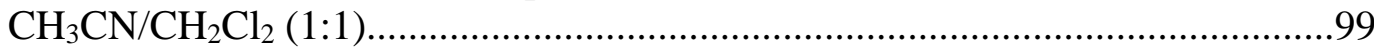

4.2 Fluorescence emission of receptor 3 in $\mathrm{CH}_{3} \mathrm{CN}$ at $\lambda_{\mathrm{exc}}=230 \mathrm{~nm} \ldots \ldots \ldots \ldots \ldots . \ldots 0$

4.3 Fluorescence titrations of 1,2 and $3\left(1.0 \times 10^{-4} \mathrm{M}\right)$ with $\mathrm{Nd}\left(\mathrm{NO}_{3}\right)_{3}$

in $\mathrm{CH}_{3} \mathrm{CN}$.

4.4 Fluorescence titrations of 1,2 and $3\left(1.0 \times 10^{-4} \mathrm{M}\right)$ with $\mathrm{Eu}\left(\mathrm{NO}_{3}\right)_{3}$

in $\mathrm{CH}_{3} \mathrm{CN}$

4.5 Fluorescence titrations of 1,2 and $3\left(1.0 \times 10^{-4} \mathrm{M}\right)$ with $\mathrm{Lu}\left(\mathrm{NO}_{3}\right)_{3}$ in $\mathrm{CH}_{3} \mathrm{CN}$.

4.6 Fluorescence titrations of 1,2 and $3\left(1.0 \times 10^{-4} \mathrm{M}\right)$ with $\mathrm{Ce}\left(\mathrm{NO}_{3}\right)_{3}$ in $\mathrm{CH}_{3} \mathrm{CN}$

4.7 Fluorescence titrations of 1,2 and $3\left(1.0 \times 10^{-4} \mathrm{M}\right)$ with $\mathrm{Sm}\left(\mathrm{NO}_{3}\right)_{3}$ in $\mathrm{CH}_{3} \mathrm{CN}$.

4.8 Fluorescence titrations of 1,2 and $3\left(1.0 \times 10^{-4} \mathrm{M}\right)$ with $\mathrm{La}\left(\mathrm{NO}_{3}\right)_{3}$ in $\mathrm{CH}_{3} \mathrm{CN}$. 104

4.9 Benesi-Hildebrand plot of receptor 1 in acetonitrile in the presence of $\mathrm{La}^{3+}$

4.10 Benesi-Hildebrand plot of receptor 1 in acetonitrile in the presence of $\mathrm{Sm}^{3+} \ldots .105$

4.11 Stern-Volmer plot of $3\left(1.0 \times 10^{-4} \mathrm{M}\right)$ with low concentration of $\mathrm{Sm}\left(\mathrm{NO}_{3}\right)_{3}$ in $\mathrm{CH}_{3} \mathrm{CN}$

4.12 Stern-Volmer plot of $3\left(1.0 \times 10^{-4} \mathrm{M}\right)$ with low concentration of $\mathrm{Lu}\left(\mathrm{NO}_{3}\right)_{3}$ in $\mathrm{CH}_{3} \mathrm{CN}$ 107

4.13 Stern-Volmer plot of $3\left(1.0 \times 10^{-4} \mathrm{M}\right)$ with low concentration of $\mathrm{Nd}\left(\mathrm{NO}_{3}\right)_{3}$ in $\mathrm{CH}_{3} \mathrm{CN}$ 108

4.14 ${ }^{1} \mathrm{H}$-NMR titration plot of 1 with $\mathrm{La}\left(\mathrm{NO}_{3}\right)_{3} \cdot 6 \mathrm{H}_{2} \mathrm{O}$ in acetone- $\mathrm{d}_{6}$. The concentration of 1 was kept constant at $2 \mathrm{mM}$. 
$4.11{ }^{1} \mathrm{H}-\mathrm{NMR}$ titration plot of 3 with $\mathrm{La}\left(\mathrm{NO}_{3}\right)_{3} \cdot 6 \mathrm{H}_{2} \mathrm{O}$ in acetonitrile- $\mathrm{d}_{3}$. The concentration of 3 was kept constant at $2 \mathrm{mM}$.

5.1 Chemical and crystal structures of receptor $\mathrm{LH}_{3}$

5.2 Fluorescence titration of $\mathrm{LH}_{3}\left(1.0 \times 10^{-6} \mathrm{M}\right)$ with $\mathrm{Hg}\left(\mathrm{CH}_{3} \mathrm{COO}\right)_{2}$ in methanol.

5.3 Fluorescence titration of $\mathrm{LH}_{3}\left(1.0 \times 10^{-6} \mathrm{M}\right)$ with $\mathrm{HgCl}_{2}$ in methanol............118

5.4 Stern-Volmer plot of $\mathrm{LH}_{3}\left(1.0 \times 10^{-6} \mathrm{M}\right)$ with low concentrations of $\mathrm{HgCl}_{2}$ in methanol.

5.5 Fluorescence titration of $\mathrm{LH}_{3}\left(1.0 \times 10^{-6} \mathrm{M}\right)$ with $\mathrm{ZnCl}_{2}$ in $\mathrm{CH}_{3} \mathrm{OH}$.

5.6 Fluorescence titration of $\mathrm{LH}_{3}\left(\lambda_{\text {exc }}=350 \mathrm{~nm}, 1 \mu \mathrm{M}\right)$ with $\mathrm{Hg}^{2+}, \mathrm{Ag}^{+}, \mathrm{Co}^{2+}$, $\mathrm{Ca}^{2+}, \mathrm{Cu}^{2+}$ and $\mathrm{Cd}^{2+}(500 \mu \mathrm{M})$ in $\mathrm{CH}_{3} \mathrm{OH}$

5.7 Fluorescence titrations of $\mathrm{LH}_{3}(1 \mu \mathrm{M})$ and $\mathrm{Et}_{3} \mathrm{~N}(3 \mu \mathrm{M})$ with $\mathrm{Hg}^{2+}$ in the presence of other cations in methanol $\left(\lambda_{\mathrm{exc}}=350 \mathrm{~nm}\right)$. The concentration of 1 was stable at all experiments $(1 \mu \mathrm{M})$. Titration with $\mathrm{Hg}(\mathrm{II})$ in the absence of competing ions (red rhombus), in constant concentration of $\mathrm{Ca}$ (II) at $1 \times 10^{-5} \mathrm{M}$, (blue triangles), and in constant concentration $1.0 \times 10^{-5} \mathrm{M}$ each of $100 \mu \mathrm{M} \mathrm{Ag}^{+}, \mathrm{Co}^{2+}$, and $\mathrm{Ca}^{2+}$ (green triangles).

5.8 ${ }^{1} \mathrm{H}-\mathrm{NMR}$ titration experiments of $\mathrm{LH}_{3}$ with $\mathrm{HgCl}_{2}$ in DMSO-d 6 . (i) $\mathrm{LH}_{3}$; (ii) $\mathrm{LH}_{3}$ with 1 equivalent of $\mathrm{Hg}$ (II); (iii) $\mathrm{LH}_{3}$ with 18 equivalent of $\mathrm{Hg}(\mathrm{II})$...

5.9 X-ray crystal structure of $\mathrm{Hg}_{3}(\mathrm{~L})\left(\mathrm{CH}_{3} \mathrm{COO}\right)_{3}$ highlighting the chair conformation of the $\mathrm{Hg}_{3} \mathrm{O}_{3}$ unit.

5.10 X-ray crystal structure of $\mathrm{Hg}_{3}(\mathrm{~L})\left(\mathrm{CH}_{3} \mathrm{COO}\right)_{3}$. Hydrogen atoms are not shown for clarity. Color coding: silver, $\mathrm{Hg}$; red, O; yellow, $\mathrm{S}$; blue, $\mathrm{N}$; dark gray, $\mathrm{C}$

5.11 X-ray crystal structure of $\mathrm{Hg}\left(\mathrm{LH}_{2}\right)_{2}$. Hydrogen atoms are not shown for clarity. Color coding: silver, $\mathrm{Hg}$; red, O; yellow, S; blue, N;

dark gray, $\mathrm{C}$

5.12 Ball and stick representation showing intermolecular $\pi-\pi$ interaction between two centroids. .125

5.13 FT-IR spectrum of $\mathrm{LH}_{3}$. .126

5.14 FT-IR spectrum of crystals of $\mathrm{Hg}_{3}(\mathrm{~L})\left(\mathrm{CH}_{3} \mathrm{COO}\right)_{3}$ 


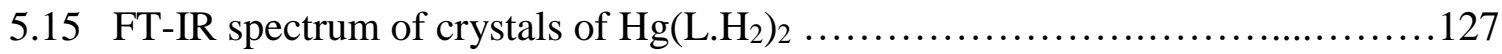

5.16 Overlay of the FT-IR spectra (crystals) of $\mathrm{Hg}\left(\mathrm{L} . \mathrm{H}_{2}\right)_{2}$ and $\mathrm{LH}_{3} \ldots \ldots \ldots \ldots \ldots \ldots$

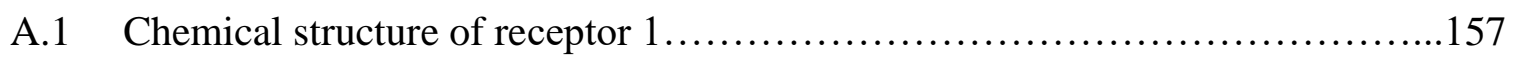

A.2 Fluorescence titration of 1 with $\mathrm{NH}_{4}{ }^{+} \mathrm{PF}_{6}{ }^{-}$in $\mathrm{CD}_{3} \mathrm{OD}\left(\lambda_{\mathrm{exc}}=272 \mathrm{~nm}\right) \ldots \ldots \ldots \ldots .159$

A.3 Fluorescence titration curve of 1 with $\mathrm{NH}_{4}{ }^{+} \mathrm{PF}_{6}^{-}\left(\lambda_{\text {exc }}=272 \mathrm{~nm}\right) \ldots \ldots \ldots \ldots \ldots . .159$

A.4 Fluorescence titration curve of 1 with $\mathrm{K}^{+} \mathrm{PF}_{6}^{-}\left(\lambda_{\mathrm{exc}}=272 \mathrm{~nm}\right) \ldots \ldots \ldots \ldots \ldots \ldots . \ldots 160$

A.5 ${ }^{1} \mathrm{H}-\mathrm{NMR}$ titration plot of 1 with $\mathrm{NH}_{4}{ }^{+} \mathrm{PF}_{6}{ }^{-}$in $\mathrm{CD}_{3} \mathrm{OD}$. The

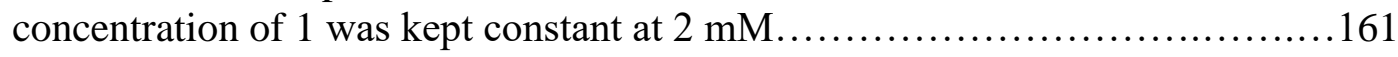

A.6 ${ }^{1} \mathrm{H}-\mathrm{NMR}$ titration plot of 1 with $\mathrm{K}^{+} \mathrm{PF}_{6}{ }^{-}$in $\mathrm{CD}_{3} \mathrm{OD}$. The concentration of

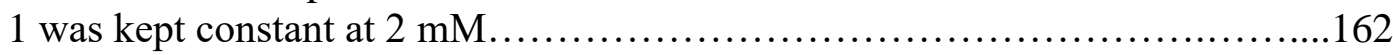

A.7 ${ }^{1} \mathrm{H}-\mathrm{NMR}$ titration plot showing selective binding of $\mathrm{NH}_{4}{ }^{+}$over $\mathrm{K}^{+}$by 1 in

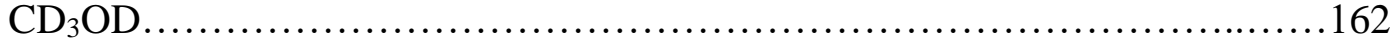

A.8 Job plot of 1 with $\mathrm{NH}_{4}{ }^{+} \mathrm{PF}_{6}{ }^{-}$in $\mathrm{CD}_{3} \mathrm{OD}$. $0.002 \mathrm{M}$ Stock solutions of 1 and $\mathrm{NH}_{4}{ }^{+} \mathrm{PF}_{6}{ }^{-}$were used.

A.9 50\% probability ORTEP thermoellipsoid (left) and PLATO (right) representations of the crystal structure of 2,4,6-triethylbenzene-1,3,5-triacetic acid, with $\mathrm{NH}_{4}{ }^{+}$and alaninol, showing $\mathrm{NH}_{4}{ }^{+}$binding to tricarboxylic acid via $\mathrm{H}$-bonding and cation- $\pi$ interactions.

A.10 Packing diagram of the crystal structure of alaninol $/ \mathrm{NH}_{4}{ }^{+} /$

2,4,6-triethylbenzene-1,3,5-triacetic acid, showing alternate layers of hydrophilic H-bonding networks and organic networks stabilized by hydrophobic interactions and crystal packing. 


\section{ABBREVIATIONS AND ACRONYMS}

\section{1,2-DCE}

An

DFT

EET

FRET

FSR

FT-IR

ICT

Ln

$\mathrm{MeOH}$

MLCT

NMR

PET

TICT

$\mathrm{UV}-\mathrm{Vis}$ 1,2-dichloroethane

Actinides

Density functional theory

Electronic energy transfer

Förster resonance energy transfer

Fluorophore spacer receptor

Fourier transform infrared spectroscopy

Internal charge transfer

Lanthanides

Methanol

Metal-to-ligand charge transfer

Nuclear magnetic resonance

Photoinduced electron transfer

Twisted internal charge transfer

Ultraviolet-visible 


\section{CHAPTER I}

A Review: Ion pair receptors and fluorescence sensing 


\subsection{Ion pair sensing.}

Ion-pair sensing is the simultaneous complexation and detection of both the cationic and anionic components of a salt. Investigations on ion pairing and specific ion-pair interactions have led to an increased recent interest in extraction, separation, and sensing systems that involve co-operative cation and anion binding. ${ }^{1-3}$ The rapid expansion in the field of supramolecular chemistry has opened routes for the uncovering of efficient and selective binding agents for application in ion pair separations and analysis. Ion pairing has found potential applications in salt extraction, ${ }^{4,5}$ membrane transport, ${ }^{6}$ catalysis ${ }^{7}$ and has also been utilized in sensing by ditopic hosts. ${ }^{8-11}$ Despite their simplicity, dual-host approaches that combine separate anion and cation receptors in co-extraction ${ }^{12}$ and sensing of ionic components have received much less attention, as there are challenges in deriving systems for which the signal response for the ion pair is unique and distinct from the signals for the individual anionic and cationic components.

\subsection{Ion pair receptors}

Ion pair binding and sensing has often involved ditopic host molecules that bind both ionic species within the same molecule. ${ }^{13-18}$ The design of ditopic host receptors comes with unique synthetic challenges: The cation-binding site must be separated from the anion binding site in a way that the two sites do not interfere with each other. Selectivity of these sites for the target ion-pair over possible interfering ion pairs must also be considered, when designing a ditopic receptor. The design of the individual binding sites is relatively straightforward, and the methods for creating individual hosts can be applied here. The difficulty lies in linking of the two binding sites, which could be a complex process and a synthetic challenge. 
Another approach to ion pair binding which has been explored by fewer researchers is the dual-host strategy, ${ }^{12,19,20}$ in which two different receptors specific for each ion pair component are used together to achieve combined extraction. The use of the dual host receptors for ion pair recognition can produce synergistic effects and in the case of fluorescent sensing, provide unique sensing signals for the pair, as opposed to the individual components, through close contact of the complexed pair components, presumably because of the lower dielectric constant of the organic solvent. One of the advantages of using the dual-host strategy over the heteroditopic receptor strategy is the avoidance of the laborious steps in synthesis of ditopic receptors.

Aside from the single ditopic host $v s$. the dual host distinction, ion pair receptors have also been classified, structurally, on the basis of how the ion pair is bound within the receptor structure. There may be: i) contact ion-pairing, ii) solvent-bridged ion pairing and iii) host-separated ion pairing. Contact ion pairing allows direct contact of the two components of the ion pair, in contrast to the solvent-separated bridge in which the solvent forms a bridge between the two component ions of the pair. In host-separated ion pairing there is no contact between the bound cation and the co-bound anion of the ion pair.

In terms of mechanism, ion pair receptors can bind the ion pair components sequentially, or in a concurrent fashion. The sequential binding involves initial binding of one of the ionic components. Once bound, the affinity of the receptor for the other ion is increased. The increase in affinity of the receptor for the other ion component in the ion pair can be as a result of either allosteric effects, or a direct or solvent-mediated electrostatic interaction with the counter ion. ${ }^{9}$ The concurrent bind mode involves the receptor forming a complex simultaneously with both the cation and the anion. In this work, we will be 
emphasizing the dual host approach, with binding by two separate hosts, which can form contact ion pairs of the complexed ions upon extraction into an organic phase. The dualhost extraction sensing strategy can take advantage of dehydration-resolvation energetics leading to selective extraction for some anions or cations from the aqueous into the organic medium. As an example, a relatively less hydrophilic anion, such as nitrate, is expected to be more extractable than the more hydrophilic chloride into organic solvents, because the higher the hydrophilicity of the anion, the higher the hydration energy barrier that needs to be overcome for anion transfer from water into an organic solvent. ${ }^{2,21}$

\subsection{Ditopic ion-pair receptors.}

\subsubsection{Ditopic receptors based on spatially separated ions.}

There are several examples of ditopic hosts, often combining crown ether sites for cation binding and hydrogen-bond donor sites for anion binding. In 1994, Reinhoudt and co-workers reported receptor $\mathbf{1}$, which contains a uranyl center, acting as a Lewis acid, which is covalently linked to two crown ether sites. Reinhoudt and co-workers showed that the receptor $\mathbf{1}$, is able to bind to $\mathrm{K}^{+}$and $\mathrm{H}_{2} \mathrm{PO}_{4}{ }^{-}$in a concurrent fashion. A single $\mathrm{K}^{+}$ion binds to both crown ether moieties in a sandwich fashion, while the anion binds to the uranyl center. $^{22}$ 

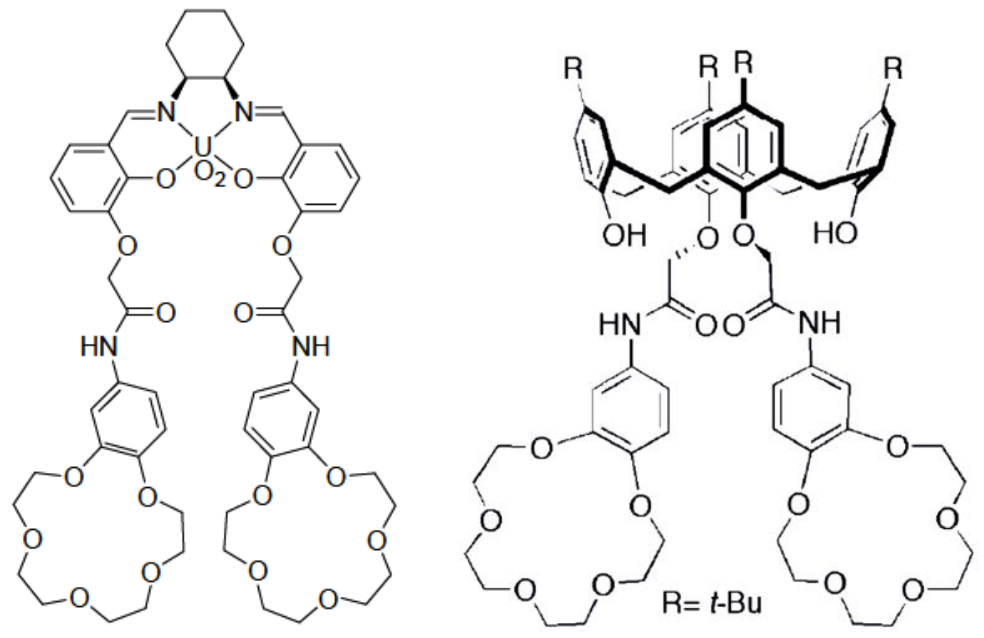

Figure 1.1. Structure of crown ether-type ditopic receptors $\mathbf{1}^{22}$ and $\mathbf{2}^{14}$

An analogous ditopic receptor was synthesized by the Beer group (receptor 2). ${ }^{14}$ The receptor 2 was found to bind potassium and ammonium cations together with several counteranions, such as $\mathrm{Cl}^{-}, \mathrm{NO}_{3}{ }^{-}, \mathrm{HSO}_{4}^{-}$, or $\mathrm{H}_{2} \mathrm{PO}_{4}{ }^{-}$. In 1994, Gellman et al. ${ }^{23}$ reported a phosphine oxide-disulfoxide system (receptor 3) that binds to monoalkylammonium cations together with halide anions. The receptor binds to the alkylammonium ion through hydrogen bonding with the three $\mathrm{P}=\mathrm{O}$ and $\mathrm{S}=\mathrm{O}$ groups. The binding of the alkylammonium ion to the three $\mathrm{P}=\mathrm{O}$ and $\mathrm{S}=\mathrm{O}$ groups led to the polarization and preorganization of the receptor, thereby allowing the cavity to be better suited for binding of the chloride anion on the opposite side of the receptor.

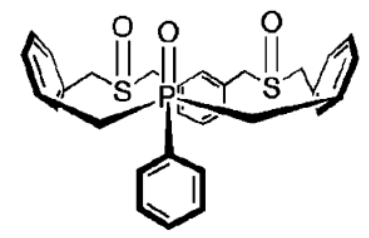

Figure 1.2. Structure of alkylammonium chloride ion pair receptor 3 reported by Gellman et al. ${ }^{23}$ 
An organotin-substituted crown ether receptor $\mathrm{Ph}_{2}(\mathrm{I}) \mathrm{SnCH}_{2} \mathrm{Sn}(\mathrm{Ph})(\mathrm{I}) \mathrm{CH}_{2}-[16]-$ crown-5 capable of binding $\mathrm{NaF}$ in acetonitrile was reported in $2007 .^{24}$ The structure reveals that in $\mathrm{CH}_{3} \mathrm{CN}$, the ion pair is spatially separated by the receptor, whereas in methanol, a solvent separated ion pair was observed, instead, in which the $\mathrm{Na}^{+}$and the $\mathrm{F}^{-}$ ions are separated by a molecule of methanol (Figure 1.3$).^{24-26}$

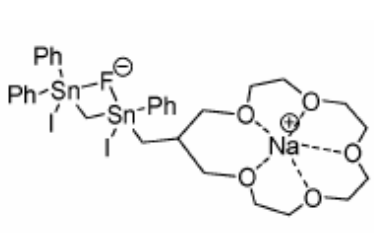

$4 a$

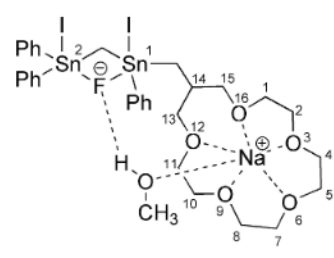

4b

Figure 1.3. Structure of $\mathrm{NaF}$ receptor $\mathbf{4} \mathbf{a}^{26}$ and $\mathbf{4} \mathbf{b}^{25}$

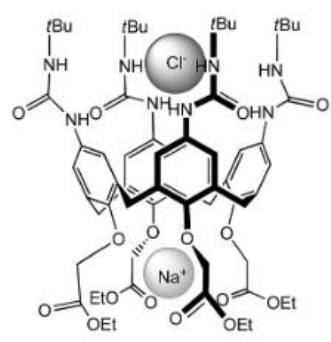

Figure 1.4. Structure of ion pair receptor 5 reported by Reinhoudt that binds $\mathrm{NaCl}^{27}$

A calix[4]-arene based ditopic receptor $5^{27,28}$ reported by Reinhoudt and coworkers was shown to bind $\mathrm{NaCl}$ as a separated ion pair: The sodium ion is bound to the ester cavity of the receptor. The binding of the sodium ion causes the molecule to pre-organize the urea groups for binding of the chloride counteranion.

\subsubsection{Ditopic receptors based on contact ion pairs.}

Ion pair receptors that bind contact ion pairs usually show higher binding affinities than ditopic receptors that separate the ion-pair components. The higher binding affinities 
for contact ion pairs arises from the reduction of the coulombic penalty associated with ion separation due to binding of the ion pair to the host molecule. ${ }^{29}$

Reetz and co-workers demonstrated one of the first examples of a ditopic host, receptor (6) on the basis of binding of an associated ion pair by coupling a crown ether moiety designed for $\mathrm{K}^{+}$recognition to a Lewis-acidic boron center designed for $\mathrm{F}^{-}$ recognition. ${ }^{18}$ The receptor $\mathbf{6}$ contains a crown ether moiety, which is used to coordinate $\mathrm{K}^{+}$, together with a Lewis acidic boron center for covalent binding of the fluoride anion, forming a 1:1 complex with KF. X-ray diffraction revealed close contact between the bound $\mathrm{K}^{+}$and $\mathrm{F}^{-}$, even though the $\mathrm{K}^{+}$is also bound to the crown ether moiety.

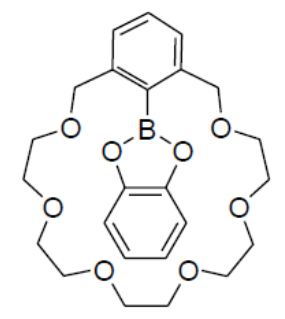

6

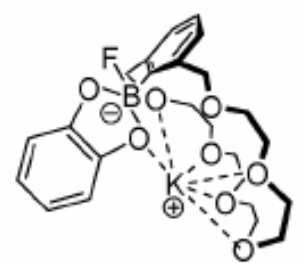

$6 \cdot \mathrm{KF}$

Figure 1.5. Structure of ion pair receptor 6 for KF binding reported by Reetz et al. ${ }^{18}$

Another example of a ditopic receptor reported by Kilburn et al, ${ }^{30}$ combining crown ether and diamide sites (7a), was shown to bind mono-potassium salts of dicarboxylic acids as contact ion pairs in chloroform. The crystal structures show hydrogen bonding interactions and an electrostatic association between the carboxylate anion and the crown ether bound potassium cation. 


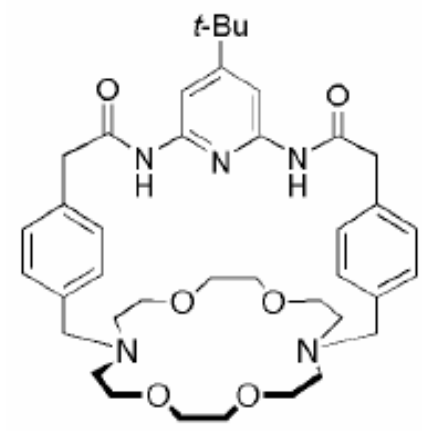

$7 \mathbf{a}$

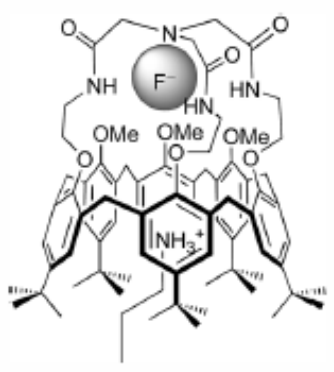

$7 \mathbf{b}$

Figure 1.6. Structure of pair receptors $7 \mathbf{a}^{30}$ and $\mathbf{7} \mathbf{b}^{31}$

A reversible and selective contact ion-pair receptor $\mathbf{7 b}$ that binds alkyl ammonium fluoride as an ion pair was reported in 2010 by Jabin et al. ${ }^{31}$ The receptor is a calix[6] cryptamide with the ammonium ion binding inside the calixarene cavity and the fluoride ion binding to the tris- amino cap present in the receptor. The observed selectivity was attributed to the size compatibility with fluoride and preorganization of the hydrogen bond donor sites.

\subsection{Dual-host ion-pair receptors.}

The dual-host strategy is another approach proposed for ion-pair recognition and sensing. This strategy employs two different receptors, each specific for the cation and anion component. These dual-host systems have found use in membrane transport and extraction of alkali metal salts. ${ }^{12,20}$ Das et al. ${ }^{32}$ have reported a dual host for $\mathrm{K}_{2} \mathrm{CO}_{3}$. In the $\mathrm{K}_{2} \mathrm{CO}_{3}$ system, a crown ether $(\mathbf{8})$ coordinates the potassium ion while a tripodal urea receptor 9 binds carbonate. X-ray diffraction analysis revealed the coordination of the potassium ion to all the ethereal oxygen atoms in the crown ether molecule and also with 
a carbonyl group and a nitro group of the tripodal urea receptor in order to satisfy an 8coordinate environment for the potassium ion.

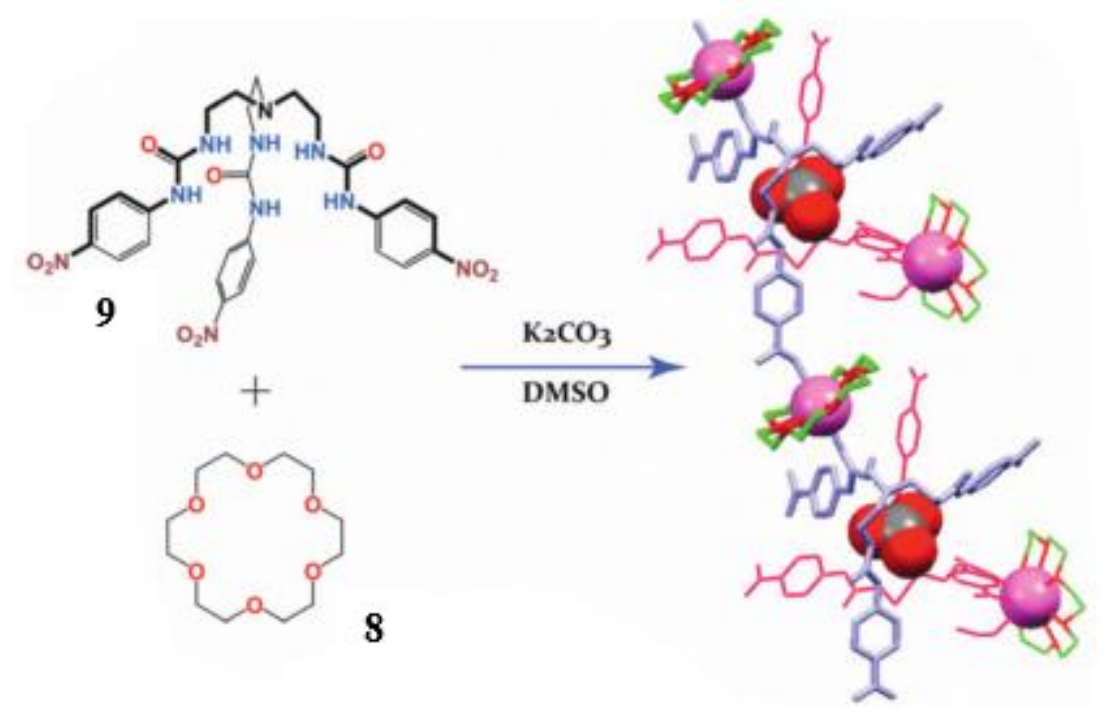

Figure 1.7. Structure of dual-host ion pair receptors reported by Das and his group. ${ }^{32}$

$\mathrm{Cafeo}^{33}$ et al. reported a dual-host combination of cationic (18-crown-6) and anionic (calix-[6]-pyrrole) receptors for effective binding of $(n-\mathrm{Bu}) \mathrm{NH}_{3}{ }^{+} \mathrm{Cl}^{-}$organic salts. Small downfield shifts occurred in the pyrrole NH resonances when 0.5 eq. of (n-Bu) $\mathrm{NH}_{3}{ }^{+} \mathrm{Cl}^{-}$was added to a calix-[6]-pyrrole solution in $\mathrm{CH}_{2} \mathrm{Cl}_{2}$, indicating a weak hostguest interaction.<smiles>C1COCCOCCOCCOCCOCCO1</smiles>

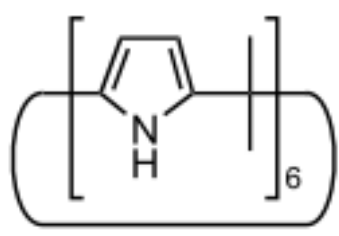

Figure 1.8. Structure of 18-crown-6 and calix-[6]-pyrrole receptors for effective binding of ion-paired $(n-\mathrm{Bu}) \mathrm{NH}_{3}{ }^{+} \mathrm{Cl}^{-}{ }^{-33}$ 
Ghosh et al. have reported $\mathrm{KF}$ and $\mathrm{KCl}$ liquid-liquid extraction into $\mathrm{CHCl}_{3}$ by equimolar amounts of 18 -crown- 6 and a tripodal amide. ${ }^{34}$ The X-ray crystal structure shows that upon binding, the potassium salts self-assemble to form a 1-D coordination polymer.
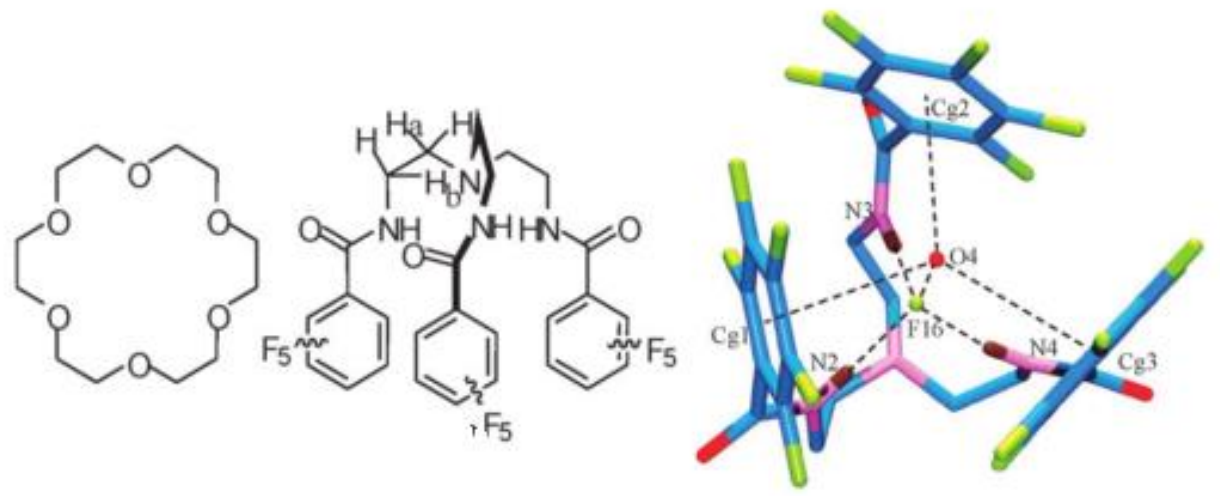

Figure 1.9. Structures of 18 -crown-6, tripodal amide and the single crystal structure of the encapsulated $\mathrm{F}^{-}$in the cavity of the tripodal amide. ${ }^{34}$

\subsection{Ion-pair receptors as sensors}

The utilization of ion pair receptors as sensors has found use in both biological and environmental systems, yet it comes with some challenges: An optical or electrochemical output is needed to be incorporated into the host design in order for a signal to be obtained. A few ditopic receptors have been utilized in ion-pair sensing. ${ }^{35-37}$ These include the ferrocene/amidopyridine type electrochemical L-phenylalanine sensor $\mathbf{1 0},{ }^{35}$ that is capable of binding the carboxylate group through the crown ether moiety and the ammonium group through the amidopyridine moiety. Large ${ }^{1} \mathrm{H}-\mathrm{NMR}$ chemical shifts changes in $\mathrm{CD}_{3} \mathrm{CN}$ were observed upon L-phenylalanine binding. 


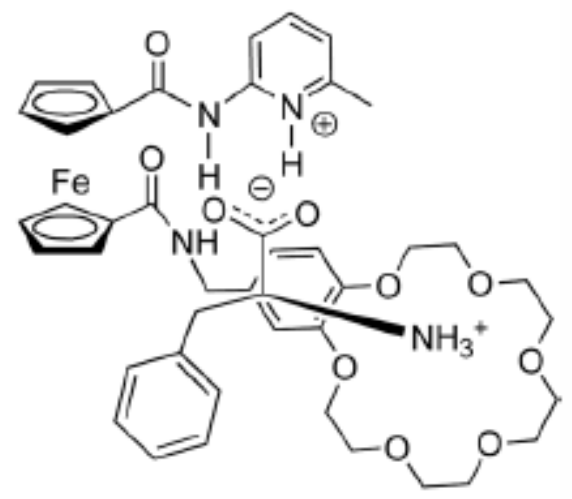

Figure 1.10. Structure of ferrocene-based amidopyridine receptor ${ }^{35} \mathbf{1 0}$ reported by Tucker et al.

Another ion-pair receptor that acts as both a fluorescent and electrochemical sensor is the ferrocene/imidazopyrene compound ${ }^{37} \mathbf{1 1}$, which is capable of binding $\mathrm{Zn}\left(\mathrm{H}_{2} \mathrm{PO}_{4}\right)_{2}$ through the imidazole moeity in the receptor. The electrochemical output signal upon binding was the result of change in the oxidation potential for the ferrocene/ferrocinium redox couple.

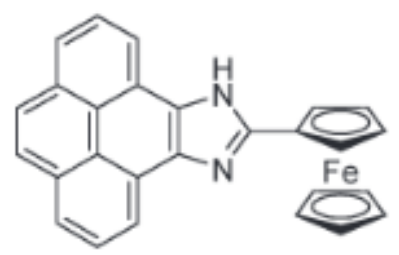

Figure 1.11 Structure of ferrocene/imidazopyrene receptor ${ }^{37} 11$ reported by Molina et al.

De Silva et al. published in the structure of the fluorescent sensor $\mathbf{1 2}$ that is able to detect the presence of sodium and phosphate ion pair simultaneously. ${ }^{38}$ The fluorescent receptor consists of a crown ether known for its high selectivity towards the sodium ion together with a polyamine moiety for phosphate binding. Fluorescence enhancement of the 
anthracene fluorophore was observed at acidic $\mathrm{pH}$ when the $\mathrm{NaH}_{2} \mathrm{PO}_{4}$ ion pair was introduced to the receptor.

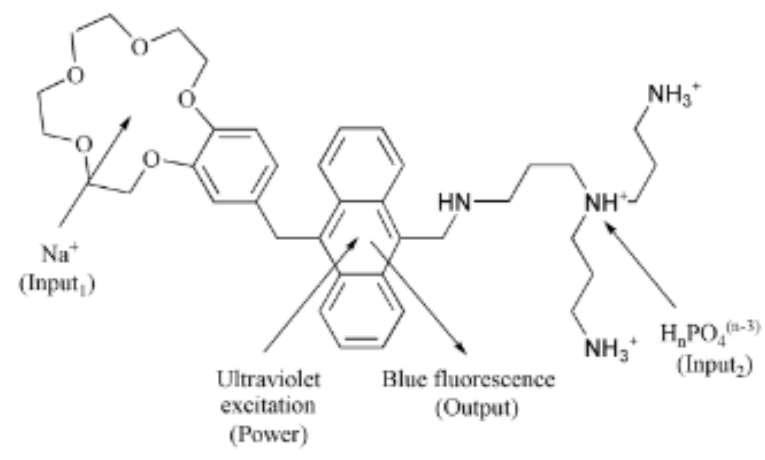

Figure 1.12. Structure of ferrocene/imidazopyrene receptor 12 reported by De Silva et al. ${ }^{38}$

\subsection{Ion-pair extraction}

Ion pair extraction involves three components: The aqueous layer, the organic layer and the interface between the two phases. ${ }^{39}$ Unlike ion-exchange extraction, in which one of the ions is exchanged, in ion-pair extraction the cation and its counteranion are both transported into the organic phase. Two approaches can be utilized in ion pair extraction: One is the use of a ligand system that can extract both the cation and the anion into the organic layer, such as in the salen-type ditopic receptor reported by Tasker et al. ${ }^{40-42}$ (Figure 1.13), in which the binding site for the sulfate anion is covalently attached to the salen metal-complexing moiety. The other approach is the dual host by individual cation and anion receptors. Unlike ditopic receptors, in which binding for both cation and the anion is achieved with a single extractant, in dual-host systems two individual cation and anion hosts, are used together. An example of ion pair extraction using a dual-host system was reported by Moyer et al. ${ }^{20}$, where the combination of an anion host that used the tripodal 
1,3,5-tricarboxamide framework with the $\mathrm{Cs}^{+}$host tetrabenzo-24-crown-8, showed extraction of $\mathrm{CsNO}_{3}$ as an ion pair from water into 1,2-dichloroethane. The $\mathrm{Cs}^{+}$extraction was enhanced by a factor of 4.4 in the presence of the nitrate receptor. The same authors ${ }^{43}$ reported an analogous system using a $\mathrm{Cs}(\mathrm{I})$-selective calix-crown extractant as the cation host together with a disulfonamide anion host for extraction of cesium salts. When the anion host is used together with the selective calix-crown cation receptor it strongly synergizes the extraction of cesium salts in 1,2-dichloroethane. Bates et al. ${ }^{44}$ have also used the dual-host approach in extracting nickel sulfate. ${ }^{42}$
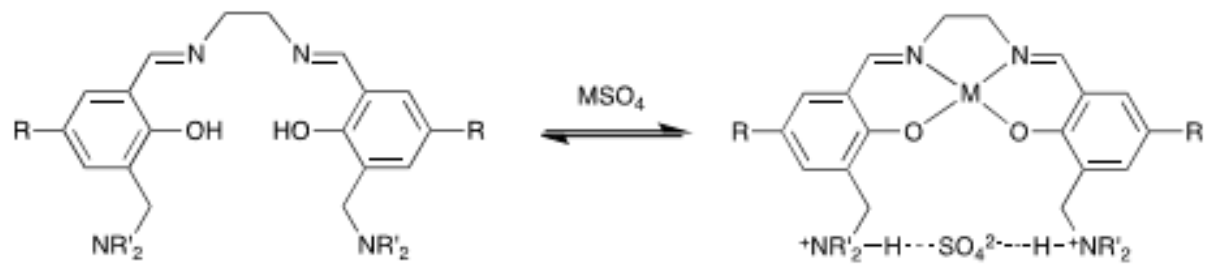

Figure 1.13 Metal sulfate binding with a salen-based receptor reported by Tasker. ${ }^{42}$

\subsection{Solvation effects in ion pairing}

Solvent effects in ion pairing have been studied right from the introduction of the concept of ion pairing. Bjerrum in 1926 has studied the effects of solvation in ion pairing in strong electrolytes. The choice of solvent can affect the energetics of host-guest binding in molecular recognition. Bulk permittivity of the solvent, $\varepsilon$, (the electrostatic attraction between oppositely charged ions in solution that causes them to form ion pairs) has been considered as the main effect solvation has on ion pairing. Another solvent effect on ion pairing is the competition between the solvent and the counterion for space in the presence of an ion in an electrolyte solution. ${ }^{45}$ Diederich and his group have reported the effects of solvent on hydrophobic binding interactions. ${ }^{46}$ Solvent effects can have notable influence 
on the binding propensities of host-guest complexes, which are promoted by electrostatic or hydrophobic interactions. When salts are in aqueous media, they exist as free ions, in organic medium because of the low dielectric constants and because they are charged, we can achieve distinct ion pairing, and can take advantage of intermolecular effects like FRET, which could be unique of the ion pair compared to the signal seen from the individual ions. Ion pair extraction can occur because of low dielectric constant, and having the right fluorophore, unique fluorescence effects can be achieved for the ion pair as opposed to the individual ions.

\subsection{Fluorescence sensors}

In the design of a fluorescent sensor, several approaches can be undertaken. In the fluorophore-spacer-receptor (FSR) approach, a light-emitting fragment is covalently linked to a receptor subunit, which is also a quencher. In the presence of an analyte the quenching no longer occurs and the fluorescence turns on. In the chemosensing ensemble, a fluorescence indicator binds in solution to the receptor through noncovalent interactions. The chemosensing approach ${ }^{47-49}$ is based on competition between the bound indicator and the competing analyte for binding to the receptor. For the chemosensing approach, the interaction between the receptor and the indicator must not be too strong and the optical properties of the indicator when bound to the receptor and when dispersed in solution must be different. Fabbrizzi and coworkers ${ }^{50}$ reported an example in which displacement of the indicator by the competing carbonate ion from the dinuclear $\mathrm{Cu}(\mathrm{II})$ macrobicyclic complex receptor core results in visible light emission. The same group used a dicopper(II) host for sensing pyrophosphate in water at $\mathrm{pH}$ 7. Coupling of the fluorescent indicator to the 
dicopper(II) receptor led to complete quenching of the emission when titrating a solution of the indicator with a standard receptor solution.

There are also other approaches that use fluorescence enhancement or quenching through both covalent or non-covalent interactions, as a result of electron transfer, and other phenomena, such as formation of excimers. Apart from the design considerations, other factors need to be taken into account when designing fluorescent sensors, especially with regard to the fluorophore properties. The choice of fluorophore must show reproducible and quantitative change in the fluorescence properties upon ion binding. Charge-transfer processes, photoinduced electron transfer (PET) processes, or electronic energy transfer (EET) processes could be used to attain this effect.

\subsubsection{The charge transfer processes}

The charge transfer processes include an all-organic internal charge transfer (ICT), ${ }^{51 a}$ a metal-to-ligand charge transfer (MLCT), ${ }^{51 \mathrm{~b}}$ a twisted internal charge transfer (TICT) ${ }^{51 \mathrm{c}}$ and through-bond charge transfer. ICT (figure 1.14) and TICT (figure 1.15) processes involve non-hydrocarbon $\pi$-electron systems where the ground state has a very different dipole moment compared to the lowest energy singlet excited state. Molecules that use TICT have their donor and acceptor portion connected by a single bond. The twisted internal charge transfer (TICT) differs from the MLCT process in that for TICT system, the full charge separation is achieved in systems by twisting the donor and acceptor components of the system by $90^{\circ}$. For the metal-to-ligand charge transfer (MLCT) process, significant changes in the luminescence properties of the receptor are induced when a guest species is bound. MLCT processes are mostly seen in organometallic complexes. ${ }^{51 \mathrm{c}}$ 


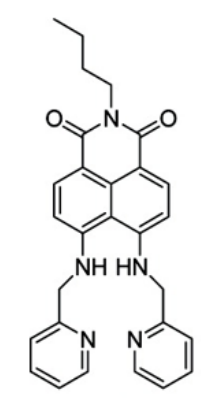

Figure 1.14. An all-organic internal charge transfer (ICT) based fluorescent sensor

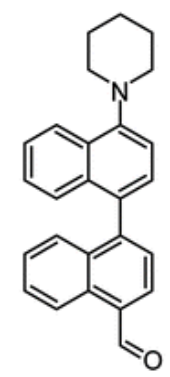

Figure 1.15. A twisted internal charge transfer (TICT) based fluorescent sensor

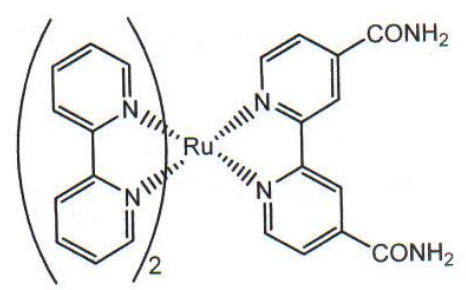

Figure 1.16. A metal-to-ligand charge transfer (MLCT) based fluorescent sensor

\subsubsection{Photoinduced electron transfer (PET)}

Photoinduced electron transfer (PET) process involves the transfer of an electron from a donor to an acceptor photochemically. PET sensors are generally designed using 
fluorophore-spacer-receptor units. The spacer unit links the fluorophore to the guest binding site and acts to preserve the independence of the chromophore and the receptor in the electronic ground state. PET-based sensors are designed as either off-/on- or on-/offfluorescence switches. Fluorescence enhancement is seen in "off-on" switches when guest binding leads to the opening of the fluorescence pathways, while fluorescence quenching is observed in "on-off" switches, when guest binding leads to the closure of fluorescence pathways. Examples of PET fluorescence sensors that use the bis-(2-picolyl) amine receptor, capable of generating a fluorescence signal upon binding zinc ions were previously reported by De Silva and coworkers. ${ }^{52,53}$ The same group has reported a fluorescent PET off-on switch sensor that uses a coumarin chromophore capable of sensing $\mathrm{Zn}^{2+}, \mathrm{Cd}^{2+}$, and $\mathrm{Pb}^{2+}$.
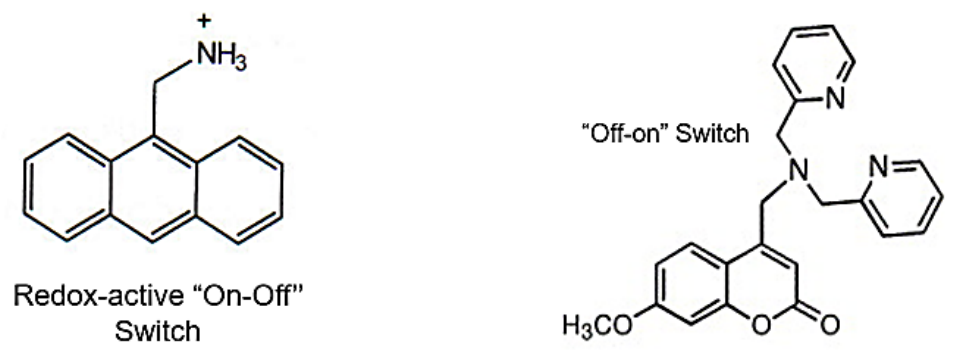

Figure 1.17. Photoinduced electron transfer (PET)-based fluorescent sensors.

\subsubsection{Electronic Energy Transfer or Förster Resonance Energy transfer (FRET)}

Electronic energy transfer (EET) or Förster resonance energy transfer (FRET), involves the transfer of energy between multiple fluorophores. It is a distance dependent nonradiative transfer of energy between a donor fluorophore initially in its electronic excited state, to an acceptor fluorophore. ${ }^{54-56 a}$ FRET is sensitive to slight changes in distance. The 
FRET process requires the donor and acceptor molecules to be in nanoscale distances to each other and the alignment of dipole moments. A critical factor in the process is the overlapping of the excitation and emission spectra of the donor and acceptor fluorophores respectively. FRET efficiency is inversely proportional to the sixth power of the distance between donor and acceptor. These systems frequently depend on guest recognitioninduced conformational changes in the host molecule for the EET process to work efficiently (Fig. 1.18).

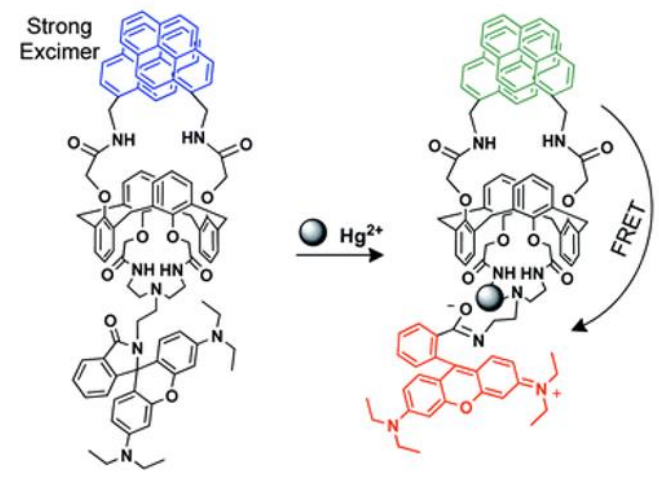

Figure 1.18. Calix[4]arene-based electronic energy transfer (EET)-based fluorescent probe for $\mathrm{Hg}(\mathrm{II}){ }^{56 \mathrm{~b}}$

\subsection{Methodology for quantifying supramolecular interactions}

There are several methods available for the determination of association constants $\mathrm{K}_{\mathrm{a}}$. The general problem is determining accurately a property (variable) of the supramolecular complex and its components that shows a regular variation upon binding, and measure it as a function of the total concentration of the one of the components. In a simple 1:1 equilibrium system, where the receptor $S$ is complexing the ligand L resulting in the $1: 1$ supramolecular complex SL, we have: 


$$
\mathrm{S}+\mathrm{L} \leftrightarrow \mathrm{SL}
$$

The 1:1 binding isotherm can be derived from the equilibrium constant to give:

$$
f_{11}=\frac{\mathrm{K}_{\mathrm{a}}[\mathrm{L}]}{1+\mathrm{K}_{\mathrm{a}}[\mathrm{L}]}
$$

$f_{11}$ represents the fraction of the receptor that has been complexed:

$$
f_{11}=\ldots[\mathrm{SL}] \quad=\ldots[\mathrm{L}]_{\mathrm{t}}-[\mathrm{L}]
$$

$[\mathrm{S}]_{\mathrm{t}} \quad[\mathrm{S}]_{\mathrm{t}}$

The value $\mathrm{L}$ from equation (3) is substituted into equation (2) and solving for $f_{11}$ we get equation 4 that contains total ligand concentration $[\mathrm{L}]_{\mathrm{t}}$, as the only variable. The equation 4 is possible if we assume that experimental conditions $[\mathrm{S}]_{\mathrm{t}}$ is kept stable:

$$
f_{11}=[\mathrm{S}]_{\mathrm{t}}+[\mathrm{L}]_{\mathrm{t}}+\mathrm{K}_{\mathrm{a}}^{-1}-\left(\left(\left([\mathrm{S}]_{\mathrm{t}}+[\mathrm{L}]_{\mathrm{t}}+\mathrm{K}_{\mathrm{a}}^{-1}\right)^{2}-4[\mathrm{~L}]_{\mathrm{t}}[\mathrm{S}]_{\mathrm{t}}\right)^{1 / 2}\right)
$$

$2[\mathrm{~S}]_{\mathrm{t}}$

The $f_{11}$ value is directly related to the measured property, and therefore non-linear fitting of the expression $f_{11}=\mathrm{f}\left([\mathrm{L}]_{\mathrm{t}}\right)$ via equation (4) allows direct determination of the association constant.

In an NMR titration experiment in which the complex and the components are in fast exchange, the chemical shift $c$ observed is the weighted average of the chemical shifts of the components.

Let $a=$ chemical shift of a specific resonance at the start of the titration when $[\mathrm{L}]_{\mathrm{t}}=0$ Then, $[\mathrm{S}]=[\mathrm{S}]_{\mathrm{t}}$ or $f_{11}=0$ 
Let $b=$ the chemical shift of the same resonance at the end of the titration when $[\mathrm{L}]_{\mathrm{t}}=\infty$ Then, $[\mathrm{S}]=0$ or $f_{11}=1$.

By defining $\Delta \delta_{\max }=b-a$

And defining $\Delta \delta=c-a$

And substituting $\mathrm{f}_{11}$ (equation 4 ) into equation 5 ,

Equation 6 can be used in order to fit the data which allows for the calculation of $\mathrm{K}_{\mathrm{a}}$ as and $\Delta \delta_{\max }$. This model can also be used for complicated equilibrium systems. ${ }^{57}$

$$
\begin{gathered}
f_{11}=\Delta \delta / \Delta \delta_{\max }=(\mathrm{c}-\mathrm{a}) /(\mathrm{b}-\mathrm{a}) \\
\Delta \delta=\frac{\left([\mathrm{S}]_{\mathrm{t}}+[\mathrm{L}]_{\mathrm{t}}+\mathrm{K}_{\mathrm{a}}^{-1}-\left(\left(\left([\mathrm{S}]_{\mathrm{t}}+[\mathrm{L}]_{\mathrm{t}}+\mathrm{K}_{\mathrm{a}}^{-1}\right)^{2}-4\left[\mathrm{~L}^{-}\right]_{\mathrm{t}}[\mathrm{S}]_{\mathrm{t}}\right)^{1 / 2}\right)\right)}{\left(2[\mathrm{~S}]_{\mathrm{t}}\right)} \Delta \delta_{\max }
\end{gathered}
$$

For fluorescence spectroscopy, in the case of enhancements the Benesi-Hildebrand analysis can be applied: In a typical fluorescence titrations experiment, the receptor was titrated with the analyte at constant receptor concentration. When addition of analyte to receptor showed an increase in fluorescence upon cation binding, the Benesi-Hildebrand equation was used to fit the data.

$$
\mathrm{I}_{0} / \mathrm{I}-\mathrm{I}_{0}=\mathrm{b} /(\mathrm{a}-\mathrm{b})\left[1 / \mathrm{K}_{\mathrm{a}}[\mathrm{M}]+1\right]
$$

Where $\mathrm{I}_{0}$ is the fluorescence intensity of the sensor in the absence of guest; $\mathrm{I}$ is the fluorescence intensity of the sensor in the presence of guest; $[\mathrm{M}]$ is the concentration of the substrates; and $\mathrm{K}_{\mathrm{a}}$ is the association constant between the receptor and the substrate. In the equation, $a$ and $b$ are constants. The value of $b /(a-b)$ can be found out by plotting 
$\mathrm{I}_{0} /\left(\mathrm{I}-\mathrm{I}_{0}\right)$ against the inverse of the concentration term, $\mathrm{M}^{-1}$. The intercept of the graph gives $b /(a-b) ; I_{0}$ and $I$ are found out experimentally.

In the case of fluorescence quenching, at lower concentrations of the analyte, a plot of $\mathrm{I}_{0} / \mathrm{I}$ vs $[\mathrm{Q}]$ is plotted and the slope obtained gives the Stern-Volmer constant $\left(\mathrm{K}_{\mathrm{sv}}\right)$. Fluorescence quenching is measured quantitatively with the Stern-Volmer equation (8) where, the quencher concentration is $[Q]$, the Stern-Volmer constant is $K_{s v}, I_{o}$ is the measured fluorescence intensity without quencher present, and I is the measured fluorescence intensity with $[\mathrm{Q}]$ present.

$$
\mathrm{I}_{\mathrm{o}} / \mathrm{I}=1+\mathrm{K}_{\mathrm{sv}}[\mathrm{Q}]
$$

\subsection{Overview of $\mathrm{NH}_{4}{ }^{+}$receptors}

Cations and anions play key role in biology and in the environment. Cations play major roles such as maintenance of life processes such as the transmission of nerve impulses and muscle contraction. Synthetic receptors for $\mathrm{NH}_{4}{ }^{+}$have found uses both in the biological (measuring the urea and creatine levels) and the environmental systems. Several ammonium ion receptors have been designed ranging from the crown ethers to nonactin, an antibiotic that can detect ammonium ions at molecular levels. ${ }^{58}$ The major goal in designing these receptors is to overcome the selectivity of $\mathrm{NH}_{4}{ }^{+}$over $\mathrm{K}^{+}$. The selectivity issue arises from the similarity in diameter between these two ions ( $286 \mathrm{pm}$ for ammonium and $266 \mathrm{pm}$ ). Kim et al. reported a thiazolo dibenzo-crown ether that is capable of binding ammonium selectively over sodium or potassium..$^{59}$ 
There are three main forces behind the binding of ammonium ion. These are ion pairs and salt bridges, hydrogen bonds, and cation- $\pi$ interactions. ${ }^{60}$ An example of ammonium binding via hydrogen bonding is nonactin. ${ }^{61}$ Binding is achieved via the four ethereal and four carbonyl oxygen atoms that bind to $\mathrm{NH}_{4}{ }^{+}$through hydrogen bonding.

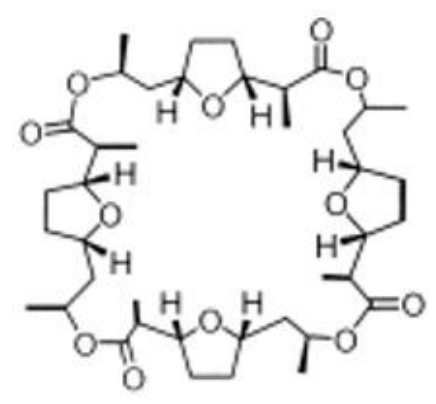

Figure 1.19. Chemical structure of nonactin

Hydrogen bonding has been utilized extensively in recognition of ammonium, with some receptors also utilizing cation- $\pi$ interactions. Kim et al.$^{62}$ reported a tris-(pyrazol-1ylmethyl)-triethylbenzene $\mathrm{NH}_{4}{ }^{+}$receptor exploiting cation- $\pi$ interactions. The receptor, was shown to be selective for binding $\mathrm{NH}_{4}{ }^{+}$over $\mathrm{K}^{+}$. The receptor selectivity towards ammonium was a result of cation- $\pi$ interactions between the substrate and the central benzene ring of the receptor. Kim et al. published a cage-type $\mathrm{NH}_{4}{ }^{+}$receptor ${ }^{63}$ that used cation- $\pi$ interactions and hydrogen bonding. This cage-type $\mathrm{NH}_{4}{ }^{+}$receptor was shown to have sensitivity and selectivity comparable or superior to nonactin over a wide range of $\mathrm{pH}$. Some of these families of receptors have also been shown to sense $\mathrm{NH}_{4}^{+}$by fluorescence with notable selectivity vs. $\mathrm{K}^{+}$(See Chapter 2). Specifically, tripodal oxazolines derived from the analogous 1,3,5-trimethylbenzene framework ${ }^{64,65}$ showed 
significant fluorescence response upon binding to $\mathrm{NH}_{4}{ }^{+}$with little response to $\mathrm{K}^{+}, \mathrm{Na}^{+}$, and $\mathrm{Mg}^{2+}$ in the $305-340 \mathrm{~nm}$ range $\left(\lambda_{\mathrm{exc}}=272 \mathrm{~nm}\right)$.

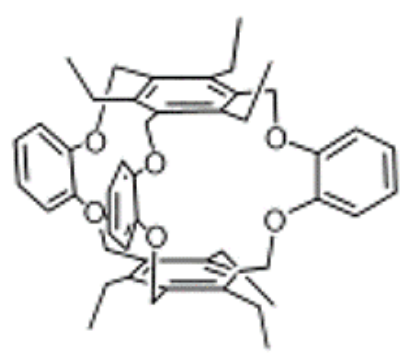

Figure 1.20. A cage-type $\mathrm{NH}_{4}{ }^{+}$receptor reported by Kim et al. based on cation- $\pi$ interactions and hydrogen bonding. ${ }^{63}$

\subsection{Overview of nitrate receptors}

The design and synthesis of anion receptors has garnered extensive interest over the recent years. In particular, selective recognition, sensing and separation of nitrate is important because of the presence of nitrate salts in many common explosives ${ }^{12}$ as well as for its environmental significance of nitrate as a pollutant. ${ }^{66}$ Building selectivity for nitrate into an anion binding host framework poses a significant challenge. The primary force behind anion-receptor binding is hydrogen bonding. Therefore, the design of an anion host should include appropriately arranged hydrogen bonding sites. A nitrate-specific host should contain hydrogen bond donor sites specifically arranged so that all three oxygen atoms of the nitrate will be bound. An example is the amide-linked $\mathrm{C}_{3}$-symmetric bicyclic neutral cyclophane published by Bisson et al. which is capable of binding nitrate exclusively through hydrogen bonding. ${ }^{67}$ Hydrogen bonds between the geometrically matched host and nitrate led to enhanced binding, overcoming the weak coordinative ability of this anion. In order for an anion host to be used as sensor, a molecular group 
whose properties change upon binding must be introduced into the framework, without interference with the actual binding site. Different examples of electrochemical and optical based anion sensors are available in the literature ${ }^{68}$ For optical sensing the most common approach is to modify the receptor with a fluorophore, whose fluorescence intensity and/or emission wavelength changes upon binding. ${ }^{69-71}$

Nitrate-responsive membrane development ${ }^{72,73}$ and other nitrate-selective optical sensors ${ }^{74,75}$ have also been reported. A nitrate-responsive optical membrane was developed by combining a highly fluorescent rhodamine-B octadecylester perchlorate (RBOE), as a dye, together with tridodecylmethylammonium chloride (TDMACl) as an anion exchanger incorporated into PVC or a PVC co-polymer. ${ }^{72}$ The nitrate-responsive optical membrane gave a limit of detection (LOD) of $1 \mathrm{ppm}$ for nitrate ion with a selectivity factor of 200 for nitrate over chloride. The use of various betaine salts in polystyrene-block-polybutadieneblock-polystyrene (SBS) polymeric membranes as nitrate-selective electrodes has also been investigated. ${ }^{73}$ The most effective of these membranes worked over a $\mathrm{pH}$ range of 2-8, with an LOD of $0.02 \mathrm{ppm}$ for nitrate. The selectivity coefficient $\left(\mathrm{K}_{\mathrm{pot}} \mathrm{NO}_{3}{ }^{-}, \mathrm{Cl}^{-}\right)$for nitrate over chloride was $3.4 \times 10^{-3}$. Fluorescent fiber-optic sensors for nitrate have been developed using the fluorescence quenching induced by the irreversible nitration of fluorescein upon exposure to nitrates. ${ }^{75}$ A system has also been reported by Huber et al. which contains a cationic potential-sensitive fluorescent dye incorporated into a hydrogelplasticizer matrix. ${ }^{74}$ This system showed strong fluorescence enhancement upon nitrate exposure and was effective in sensing nitrate in the $0.1-50 \mathrm{mM}$ range, while showing no response to the presence of chloride, even at $200 \mathrm{mM}$. These receptors have a collective effectiveness in the $\mathrm{mM}$ range and considerable selectivity over chloride. 


\subsection{Overview of mercury (II) sensors}

Over the last few decades, many efforts have been undertaken for the design and synthesis of selective $\mathrm{Hg}$ (II) receptors and sensors. The effort, arises from the toxic nature of mercury to both the human health and the environment ${ }^{76,77}$ Mercury is ranked among the priority metals that are of public health significance. ${ }^{78}$ These metallic elements are considered systemic toxicants that are known to induce multiple organ damage. Mercury pollution has been shown to originate from both natural and anthropogenic sources. Minamata diseases ${ }^{79}$ and prenatal brain damage are some of the effects that arise from mercury exposure in humans. ${ }^{80-84}$

Numerous methods have been employed in recent years for the detection of $\mathrm{Hg}(\mathrm{II})$. These include colorimetric sensing techniques, atomic absorption, X-ray fluorescence spectroscopy, and electrochemical sensing. The use of colorimetric and fluorescence sensors for $\mathrm{Hg}(\mathrm{II})$ detection stems from their low cost, operational simplicity and high selectivity. An example is the highly selective and sensitive colorimetric method that uses gold nanoparticles that utilize $\mathrm{Au}$ amalgamation and grown AuNPs for rapid $\mathrm{Hg}$ (II) detection. ${ }^{85-88}$ A number of fluorescence chemosensors have been reported in the literature for $\mathrm{Hg}(\mathrm{II})$ detection: Che et al. ${ }^{89}$ reported a fluorescent 5-bromoindole-3-carboxaldehyde ethylthiosemicarbazone receptor that can detect and remove $\mathrm{Hg}(\mathrm{II})$ from water by extraction. This ligand coordinates directly to $\mathrm{Hg}$ through its $\mathrm{N}$ and $\mathrm{S}$ atoms, and is selective towards $\mathrm{Hg}(\mathrm{II})$, with a detection limit of $1.31 \times 10^{-7} \mathrm{M}$. The rhodamine fluorophore $\mathrm{e}^{90-94}$ has found a lot of use for $\mathrm{Hg}$ detection because of its emissive performance ${ }^{95}$ and emission turn-on effect. The dansylamide fluorophore has also found uses as fluorescent probe 
because it possesses high fluorescence quantum yield and large Stokes shifts. Some dansylbased receptors have been reported for $\mathrm{Hg}(\mathrm{II})$ detection. ${ }^{96-100}$

\subsection{Overview of lanthanide receptors}

The processing and removal of high heat emitters from nuclear waste continuously poses a concern because nuclear waste streams typically contain long-lived radiotoxic minor actinides and fission products. ${ }^{101-103}$ The radiotoxicity and high heat generation in these streams is mainly a consequence of actinide presence. ${ }^{103-110}$ There is a continuous effort in generating ligands that can separate these high heat emitters from lanthanides and fission products. Selectively separating the actinides (An) from lanthanides (Ln) in used nuclear fuel presents an important challenge in closing the nuclear fuel cycle. The challenge comes from the chemical similarities between the actinides and the less harmful lanthanides in their ionic radii and identical oxidation states. Several ligands for selective separation of trivalent actinides from lanthanides, and fission products have been reported:

Gullu et al. ${ }^{111}$ have synthesized macrocyclic receptors based on the lactam ionophore. The observed change in the emission and absorption spectra of these compounds upon lanthanide addition was attributed to intramolecular energy transfer process. A fluorescent diazostilbenzene/benzo-15-crown sensor ${ }^{112}$ capable of detecting lanthanide ions with high sensitivity and resolution has also been reported. Change in ligand fluorescence was observed when equimolar amounts of lanthanide was added to a ligand solution in THF. A cyclen-based fluorescent ligand capable of detecting micromolar concentrations of Y(III) and $\mathrm{La}(\mathrm{III})$ ions in aqueous solutions was reported by Aoki et al. ${ }^{113}$ 


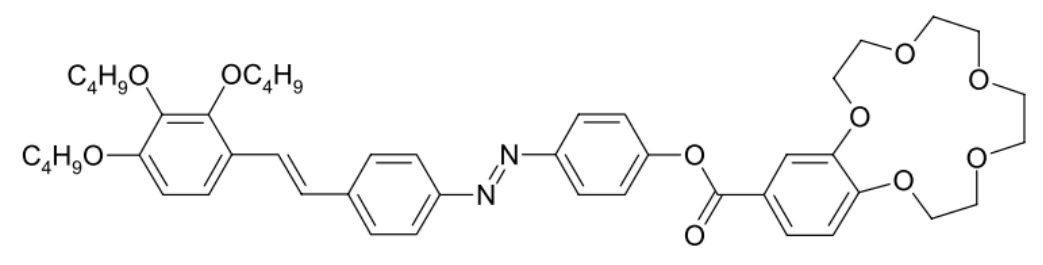

Figure 1.21. A fluorescent probe bearing a diazostilbene chromophore and a benzo-15crown-5 ether moiety reported by Bekiari et al.

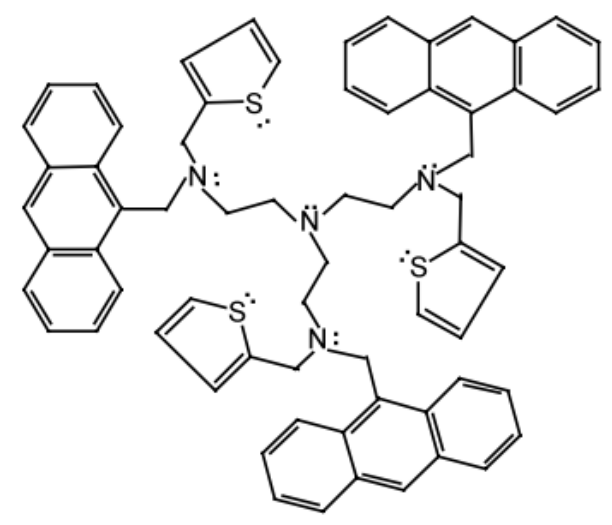

Figure 1.22. A tripodal N-anthracen-9-ylmethyl-N7,N7-bis-[2-(anthracen-9-ylmethylthiophen-2-ylmethylamino)ethyl]-N-thiophen-2-ylmethyl-ethane-1,2-diamine with Selective fluorescence enhancement for $\mathrm{Ce}^{3+}$ in dry tetrahydrofuran (THF) reported by Aoki et al .

The coordination chemistry of lanthanide ions with tripodal ligands has also been explored. ${ }^{104}$ A tripodal fluoroionophore reported by Das et al. ${ }^{104}$ shows selective fluorescence enhancement with $\mathrm{Ce}$ (III) in dry THF. The tripodal ligand, tris-(2benzimidazolylmethyl) amine complexed $\mathrm{Ln}(\mathrm{III})$ with 2:1 ligand-to-metal ratio via intramolecular $\pi-\pi$ interactions. ${ }^{114}$

\subsection{References}

(1) Munshi, M. K.; Gade, S. M.; Rane, V. H.; Kelkar, A. A. Role of Cation-Anion Cooperation in the Selective Synthesis of Glycidol from Glycerol Using DABCODMC Ionic Liquid as Catalyst. RSC Adv. 2014, 4, 32127-32133.

(2) Moyer, B. A. Complexation and transport, in: Comprehensive Supramolecular 
Chemistry, edited by Gokel, G.W. Pergamon, Elsevier, Oxford, 1996, Chap. 10, vol. 1, pp. 401-405.

(3) Evans, N. H.; Rahman, H.; Davis, J. J.; Beer, P. D. Surface-Attached Sensors for Cation and Anion Recognition. Anal. Bioanal. Chem. 2012, 402, 1739-1748.

(4) Akhuli, B.; Ghosh, P. Selective Recognition and Extraction of KBr via Cooperative Interactions with a Urea Functionalized Crown Ether Dual-Host. Chem. Commun. 2015, 51, 1-4.

(5) Wintergerst, M. P.; Levitskaia, T. G.; Moyer, B. A.; Sessler, J. L.; Delmau, L. H. Calix[4]pyrrole: A New Ion-Pair Receptor As Demonstrated by Liquid-Liquid Extraction. J. Am. Chem. Soc. 2008, 130, 4129-4139.

(6) Haynes, C. J. E.; Gale, P. A. Transmembrane Anion Transport by Synthetic Systems. Chem. Commun. (Camb). 2011, 47, 8203-8209.

(7) Brak, K.; Jacobsen, E. N. Asymmetric Ion-Pairing Catalysis. Angew. Chemie - Int. Ed. 2013, 52, 534-561.

(8) Molina, P.; Tarraga, A.; Alfonso, M. Ferrocene-Based Multichannel Ion-Pair Recognition Receptors. Dalt. Trans. 2014, 43, 18-29.

(9) B.D, S. In Ion Pair Recognition by Ditopic Receptors, Macrocyclic Chemistry: Current Trends and Future Perspectives.; Gloe K, A. B., Ed.; Kluwer, London, 2005.

(10) Kirkovits, G. J.; Shriver, J. A.; Gale, P. A.; Sessler, J. L. Synthetic Ditopic Receptors. J. Incl. Phenom. Macrocycl. Chem. 2001, 41, 69-75.

(11) Antonisse, M. M. G.; Reinhoudt, D. N. Neutral Anion Receptors: Design and Application. Chem. Commun. 1998, 443-448.

(12) Kavallieratos, K.; Danby, A.; Berkel, G. J. Van; Kelly, M. A; Sachleben, R. A; Moyer, B. A; Bowman-James, K. Enhancement of $\mathrm{CsNO}_{3}$ Extraction in 1,2Dichloroethane by Tris ( 2-Aminoethyl ) Amine Triamide Derivatives via a DualHost Strategy Pairwise Anion / Cation Separations. 2008, 72, 5258-5264.

(13) Beer, P. D.; Bernhardt, P. V. ferrocene functionalised macrocyclic receptor for cations and anions. J. Chem. Soc., Dalt. Trans. 2001, 1428-1431.

(14) Beer, P. D.; Drew, M. G. B.; Knubley, R. J.; Ogden, M. I. Synthesis and coordination chemistry of a novel bis(benzo crown ether) substituted calix[4]arene that can simultaneously complex cations and anions.. J. Chem. Soc., Dalt. Trans. 1995, 3117-3123.

(15) Cooper, J. B.; Drew, M. G. B.; Beer, P. D. Alkali Metal Cation Cooperative Anion Recognition by Heteroditopic bis(calix[4]arene) rhenium(I) Bipyridyl and Ferrocene Receptor Molecules. J. Chem. Soc. Dalt. Trans. 2000, 2721-2728. 
(16) Cooper, J. B.; Drew, M. G. B.; Beer, P. D. Heteroditopic rhenium(I) and ruthenium(II) bipyridyl calix[4]arene receptors for binding cation-anion ion pairs. J. Chem. Soc., Dalt. Trans. 2001, 392-401.

(17) Rudkevich, D. M.; Mercer-Chalmers, J. D.; Verboom, W.; Ungaro, R.; de Jong, F.; Reinhoudt, D. N. Bifunctional Recognition: Simultaneous Transport of Cations and Anions through a Supported Liquid Membrane. J. Am. Chem. Soc. 1995, 117, 61246125.

(18) Reetz, M. T.; Niemeyer, C. M.; Harms, K. Crown Ethers with a Lewis Acidic Center: A New Class of Heterotopic Host Molecules. Angew. Chemie Int. Ed. English 1991, 30, 1472-1474.

(19) D. Beer, P.; K. Hopkins, P.; D. McKinney, J. Cooperative Halide, Perrhenate AnionSodium Cation Binding and Pertechnetate Extraction and Transport by a Novel Tripodal Tris(amido Benzo-15-Crown-5) Ligand. Chem. Commun. 1999, 12531254.

(20) Kavallieratos, K.; Sachleben, R. A.; Van Berkel, G. J.; Moyer, B. A. Novel DualHost Approach in Ion Pair Extraction: A Simple Tripodal Nitrate Host Facilitates $\mathrm{CsNO}_{3}$ Transfer to 1,2-Dichloroethane by a Large Crown Ether. Chem. Commun. 2000, 187-188.

(21) Moyer, B. A., Bonnesen, P. V. Supramolecular Chemistry of Anions, edited by Bianchi, A.; Bowman-James. K.; Garcfa- Espafia E. Wiley-VCH.; Wiley-VCH: NewYork, 1997.

(22) Rudkevich, D.M., Brzozka, Z., Palys, M., Visser, H.C., Verboom, W.; and Reinhoudt, D.N. A Difunctional Receptor for the Simultaneous Complexation of Anions and Cations; Recognition of $\mathrm{KH}_{2} \mathrm{PO}_{4}$. Angew Chem, Int Ed Engl. 1994, 33, 467-469.

(23) Savage, P. B.; Holmgren, S. K.; Gellman, S. H. Anion and Ion Pair Complexation by a Macrocyclic Phosphine Oxide Disulfoxide. J. Am. Chem. Soc. 1994, 116, 40694070 .

(24) Reeske, G.; Bradtmöller, G.; Schürmann, M.; Jurkschat, K. Solubilizing Sodium Fluoride in Acetonitrile: Synthesis, Molecular Structure, and Complexation Behavior of Bis(organostannyl)methyl-Substituted Crown Ethers. Chem. - A Eur. J. 2007, 13, 10239-10245.

(25) Reeske, G.; Schurmann, M.; Jurkschat, K. Charge Separation by Ditopic Complexation in the Solid State: Molecular Structure of $\left\{\mathrm{Ph}_{2}(\mathrm{I}) \mathrm{SnCH}_{2} \mathrm{Sn}(\mathrm{Ph})(\mathrm{I}) \mathrm{CH}_{2}-[16]-\mathrm{Crown}_{-5}\right\} \mathrm{NaFCH}_{3} \mathrm{OH}$. Dalt. Trans. 2008, 33983400 . 
(26) Reeske, G.; Schürmann, M.; Costisella, B.; Jurkschat, K. Ph(3-n)XnSnCH2-16Crown-5 (X = F, Cl, Br, I, SCN; $\mathrm{N}=1,2)$ : Intramolecular $\mathrm{O} \rightarrow$ Sn Coordination versus Ditopic Complexation of Sodium Thiocyanate. Organometallics 2007, 26, 4170-4179.

(27) Scheerder, J.; Duynhoven, J. P. M. van; Engbersen, J. F. J.; Reinhoudt, D. N. Solubilization of $\mathrm{NaX}$ Salts in Chloroform by Bifunctional Receptors. Angew. Chemie Int. Ed. English 1996, 35, 1090-1093.

(28) Scheerder, J.; Duynhoven, J. P. M. Van; Engbersen, J. F. J.; Reinhoudt, D. N. Solubilisierung von NaXSalzen in Chloroform Durch Difunktionelle Rezeptoren. Angew. Chemie 1996, 108, 1172-1175.

(29) Mahoney, J. M.; Beatty, A. M.; Smith, B. D. Selective Recognition of an Alkali Halide Contact Ion-Pair. J. Am. Chem. Soc. 2001, 123, 5847-5848.

(30) Flack, S. S.; Chaumette, J.-L.; Kilburn, J. D.; Langley, G. J.; Webster, M. A Novel Receptor for Dicarboxylic Acid Derivatives. Chem. Commun. 1993, 399-401.

(31) Lascaux, A.; Le Gac, S.; Wouters, J.; Luhmer, M.; Jabin, I. An Allosteric Heteroditopic Receptor for Neutral Guests and Contact Ion Pairs with a Remarkable Selectivity for Ammonium Fluoride Salts. Org. Biomol. Chem. 2010, 8, 4607-4616.

(32) Chutia, R.; Dey, S. K.; Das, G. A Supramolecular Dual-Host Based Ion-Pair Induced Formation of 1D Coordination Polymer. Cryst. Eng. Comm 2013, 15, 9641-9647.

(33) Cafeo, G.; Gattuso, G.; Kohnke, F. H.; Notti, A.; Occhipinti, S.; Pappalardo, S.; Parisi, M. F. Remarkable Boosting of the Binding of Ion-Paired Organic Salts by Binary Host Systems. Angew. Chemie Int. Ed. 2002, 41, 2122-2126.

(34) Ravikumar, I.; Saha, S.; Ghosh, P. Dual-Host Approach for Liquid-Liquid Extraction of Potassium Fluoride/chloride via Formation of an Integrated 1-D Polymeric Complex. Chem. Commun. 2011, 4721-4723.

(35) Miyaji, H.; Gasser, G.; Green, S. J.; Molard, Y.; Strawbridge, S. M.; Tucker, J. H. R. Selective Electrochemical Sensing of Acidic Organic Molecules via a Novel Guest-to-Host Proton Transfer Reaction. Chem. Commun. 2005, 5355-5357.

(36) McConnell, A. J.; Beer, P. D. Heteroditopic Receptors for Ion-Pair Recognition. Angew. Chemie - Int. Ed. 2012, 51, 5052-5061.

(37) Alfonso, M.; Espinosa, A.; Tárraga, A.; Molina, P. A Simple but Effective Dual Redox and Fluorescent Ion Pair Receptor Based on a Ferrocene-Imidazopyrene Dyad. Org. Lett. 2011, 13, 2078-2081.

(38) De Silva, A. P.; McClean, G. D.; Pagliari, S. Direct Detection of Ion Pairs by Fluorescence Enhancement. Chem. Commun. 2003, 2010-2011.

(39) Brandstrom, A. Ion-Pair Extraction as a Tool for the Study of Mechanisms of Reactions Related to Phase Transfer Catalysis. Pure Appl. Chem. 1982, 54 , 17691782. 
(40) White, D. J.; Laing, N.; Miller, H.; Parsons, S.; Tasker, P. A. Ditopic Ligands for the Simultaneous Solvent Extraction of Cations and Anions Incorporation of a Dianionic Binding Site for Transition Metal Cations and a Dicationic Binding Site for Anions into a Lipophilic Molecule Has Produced a Ligand with a High. Chem. Commun. 1999, 2077-2078.

(41) Galbraith, S. G.; Plieger, P. G.; Tasker, P. A. Cooperative Sulfate Binding by Metal Salt Extractants Containing 3-Dialkylaminomethylsalicylaldimine Units. Chem. Commun. 2002, 2662-2663.

(42) Coxall, R. A.; Lindoy, L. F.; Miller, H. A.; Parkin, A.; Parsons, S.; Tasker, P. A.; White, D. J. Solvent Extraction of Metal Sulfates by Zwitterionic Forms of Ditopic Ligands. Dalt. Trans. 2003, 55-64.

(43) Kavallieratos, K.; Moyer, B. A. Attenuation of Hofmeister Bias in Ion-Pair Extraction by a Disulfonamide Anion Host Used in Strikingly Effective Synergistic Combination with a Calix-Crown $\mathrm{Cs}^{+}$Host. Chem. Commun. 2001, 1620-1621.

(44) Bates, G. W.; Davidson, J. E.; Forgan, R. S.; Gale, P. A.; Henderson, D. K.; King, M. G.; Light, M. E.; Moore, S. J.; Tasker, P. A.; Tong, C. C. A Dual Host Approach to $\mathrm{NiSO}_{4}$ Extraction. Supramol. Chem. 2012, 24, 117-126.

(45) Stockhausen, M. J. M. G. Barthel, H. Krienke, and W. Kunz: Physical Chemistry of Electrolyte Solutions: Modern Aspects (Topics in Physical Chemistry, Vol. 5, Ed. by Deutsche Bunsengesellschaft), Steinkopff, Darmstadt/Springer, New York, 1998, ISBN 3-7985-1076-8, XVII+401. Berichte der Bunsengesellschaft für Phys. Chemie 1998, 102, 1521.

(46) Smithrud D. B., Sanford, E. M. , Chao, I., Ferguson, S. B., Carcanague, D. R., Evanseck, J. D., Houk , K. N., Diederich, F. Solvent Effects in Molecular Recognition. Pure Appl. Chem 1990, 62, 2227.

(47) Niikura, K.; Metzger, A.; Anslyn, E. V. Chemosensor Ensemble with Selectivity for Inositol-Trisphosphate. J. Am. Chem. Soc. 1998, 120, 8533-8534.

(48) Metzger, A.; Anslyn, E. V. A Chemosensor for Citrate in Beverages. Angew. Chem., Int. Ed. 1998, 37, 649-652.

(49) Lavigne, J.; Anslyn, E. V. Teaching Old Indicators New Tricks: A Colorimetric Chemosensing Ensemble for Tartrate/Malate in Beverages. Angewandte Chemie International Edition, Angew. Chemie, Int, Ed. 1999, 38, 3666-3669.

(50) Fabbrizzi, L., Marcotte, N., Stomeo, F. and Taglietti, A. Pyrophosphate Detection in Water by Fluorescence Competition Assays: Inducing Selectivity through the Choice of the Indicator. Angew. Chemie Int. Ed. 2002, 41, 3811-3814.

(51) (a) Xu, Z.; Xiao, Y.; Qian, Z.; Cui, J.; Cui, D. Ratiometric and Selective Fluorescent Sensor for CuII Based on Internal Charge Transfer (ICT). Org. Lett. 2005, 7, 889-892. (b) de Silva, A. P.; Gunaratne, H. Q. N.; Gunnlaugsson, T.; Huxley, A. J. M.; McCoy, C. P.; Rademacher, J. T.; Rice, T. E. Signaling 
Recognition Events with Fluorescent Sensors and Switches. Chem. Rev. 1997, 97, 1515-1566. (c) Sasaki, S.; Niko, Y.; Igawa K.; Konishi, G. Aggregation-induced emission active D- $\pi$-A binaphthyl luminophore with dual-mode fluorescence $R S C$ Adv., 2014, 4, 33474-33477

(52) De Silva, S. A., Kasner, M. L., Whitener, M. A. and Pathirana, S. L. A Computational Study of a Fluorescent Photoinduced Electron Transfer (PET) Sensor for Cations. Int. J. Quantum Chem. 2004, 100, 753-757.

(53) de Silva, S.A.; Zavaleta, A. Fluorescent Photoinduced Electron Transfer Sensor for Cations with an off-on-off Proton Switch. Tetrahedron Lett. 1997, 38, 2237-2240.

(54) Harris, D. "Applications of Spectrophotometry". Quantitative Chemical Analysis 8th ed.; W. H. Freeman and Co.: New York, 2010.

(55) Cheng, P.-C. "The Contrast Formation in Optical Microscopy". In Pawley, James B. Handbook Of Biological Confocal Microscopy; Springer.: New York, 2006; pp. 162-206.

(56) (a) Helms, V. "Fluorescence Resonance Energy Transfer". Principles of Computational Cell Biology.; Wiley-VCH: NewYork, 2008. (b) Lee, Y. H.; Lee, M. H.; Zhang J. F.; Kim, J. S. Pyrene Excimer-Based Calix [4] arene FRET Chemosensor for Mercury (II). J. Org. Chem., 2010, 75, 7159

(57) Connors, K. A. Binding Constants; Wiley: New York, 1987.

(58) Chin, J.; Oh , J.; Jon S.Y.; Park, S. H.; Walsdorff, C.; Stranix , B.; Ghoussoub, A.; Lee, S. K.; Chung, H. J.; Park, S. M.; Kim, K. Tuning and Dissecting Electronic and Steric Effects in Ammonium Receptors: Nonactin vs Artificial Receptors. J. Am. Chem. Soc. 2002, 124, 5374-5379.

(59) Kim, H. S.; Do, K. S.; Kim, K. S.; Shim, J. H.; Cha, G. S.; Nam, H. Ammonium Ion Binding Property of Naphtho-Crown Ethers Containing Thiazole as Sub-Cyclic Unit. Bull. Korean Chem. Soc. 2004, 25, 1465-1470.

(60) Späth, A.; König, B. Molecular Recognition of Organic Ammonium Ions in Solution Using Synthetic Receptors. Beilstein J. Org. Chem.2010, 6, 1-111.

(61) Neupert-Laves, K.; Dobler, M. The Crystal Structure of the $\mathrm{NH}_{4} \mathrm{NCS}$ Complex of Nonactin. Helv. Chim. Acta. 1976, 59, 614-623.

(62) Chin, J.; Walsdorff, C.; Stranix, B.; Oh, J.; Chung, H. J.; Park, S. M.; Kim, K. A Rational Approach to Selective Recognition of $\mathrm{NH}_{4}{ }^{+}$over $\mathrm{K}^{+}$. Angew. Chemie - Int. Ed. 1999, 38, 2756-2759.

(63) Jon, S. Y.; Kim, J.; Kim, M.; Park, S.; Jeon, W. S.; Heo, J.; Kim, K. A Rationally Designed $\mathrm{NH}_{4}{ }^{+}$Receptor Based on Cation- $\pi$ Interaction and Hydrogen Bonding. Angew. Chemie 2001, 113, 2174-2177. 
(64) Ahn, K. H.; Kim, S.-G.; Jung, J.; Kim, K.-H.; Kim, J.; Chin, J.; Kim, K. Selective Recognition of $\mathrm{NH}_{4}{ }^{+}$over $\mathrm{K}^{+}$with Tripodal Oxazoline Receptors. Chem. Lett. 2000, 29, 170-171.

(65) Ahn, K. H.; Ku, H. Y.; Kim, Y.; Kim, S. G.; Kim, Y. K.; Son, H. S.; Ku, J. K. Fluorescence Sensing of Ammonium and Organoammonium Ions with Tripodal Oxazoline Receptors. Org. Lett. 2003, 5, 1419-1422.

(66) Cho, S. J.; Sasaki, S.; Ikebukuro, K.; Karube, I. A Simple Nitrate Sensor System Using Titanium Trichloride and an Ammonium Electrode. Sensors Actuators B Chem. 2002, 85, 120-125.

(67) Bisson, A. P.; Lynch, V. M.; Monahan, M.-K. C.; Anslyn, E. V. Recognition of Anions through $\mathrm{NH}-\pi$ Hydrogen Bonds in a Bicyclic Cyclophane Selectivity for Nitrate. Angew. Chemie Int. Ed. English 1997, 36, 2340-2342.

(68) Valiyaveettil, S.; Engbersen, J. F. J.; Verboom, W.; Reinhoudt, D. N. Synthesis and Complexation Studies of Neutral Anion Receptors. Angew. Chemie Int. Ed. English 1993, 32, 900-901.

(69) Corradini, R.; Dossena, A.; Galaverna, G.; Marchelli, R.; Panagia, A.; Sartor, G. Fluorescent Chemosensor for Organic Guests and Copper(II) Ion Based on Dansyldiethylenetriamine-Modified $\beta$-Cyclodextrin. J. Org. Chem. 1997, 62, 62836289.

(70) Ikeda, H.; Nakamura, M.; Ise, N.; Toda, F.; Ueno, A. NMR Studies of Conformations of N-Dansyl-L-Leucine-Appended and N-Dansyl-D-LeucineAppended $\beta$-Cyclodextrin as Fluorescent Indicators for Molecular Recognition. $J$. Org. Chem. 1997, 62, 1411-1418.

(71) Hamasaki, K.; Ikeda, H.; Nakamura, A.; Ueno, A.; Toda, F.; Suzuki, I.; Osa, T. Fluorescent Sensors of Molecular Recognition. Modified Cyclodextrins Capable of Exhibiting Guest-Responsive Twisted Intramolecular Charge Transfer Fluorescence. J. Am. Chem. Soc. 1993, 115, 5035-5040.

(72) Effects of the Polymer Matrix on an Optical Nitrate Sensor Based on a PolaritySensitive Dye. Sensors Actuators B Chem. 1996, 37, 103-109.

(73) Le Goff, T.; Braven, J.; Ebdon, L.; Scholefield, D. High-Performance NitrateSelective Electrodes Containing Immobilized Amino Acid Betaines as Sensors. Anal. Chem. 2002, 74, 2596-2602.

(74) Huber, C., Klimant, I., Krause, C., Werner, T., Wolfbeis, O. Nitrate-Selective Optical Sensor Applying a Lipophilic Fluorescent Potential-Sensitive Dye. Anal. Chim. Acta 2001, 449, 81-93.

(75) Mahieuxe, B.; Carré, M. C.; Viriot, M. L.; André, J. C.; Donner, M. Fiber-Optic Fluorescing Sensors for Nitrate and Nitrite Detection. J. Fluoresc. 1994, 4, 7-10. 
(76) Renzoni, A.; Zino, F.; Franchi, E. Mercury Levels along the Food Chain and Risk for Exposed Populations. Environ. Res. 1998, 77, 68-72.

(77) Harris, H. H.; Pickering, I. J.; George, G. N. The Chemical Form of Mercury in Fish. Science. 2003, 301, 1203.

(78) Tchounwou, P. B.; Yedjou, C. G.; Patlolla, A. K.; Sutton, D. J. Heavy Metals Toxicity and the Environment. EXS 2012, 101, 133-164.

(79) Akagi, H.; Grandjean, P.; Takizawa, Y.; Weihe, P. Methylmercury Dose Estimation from Umbilical Cord Concentrations in Patients with Minamata Disease. Environ. Res. 1998, 77, 98-103.

(80) Cavalleri, A.; Gobba, F. Reversible Color Vision Loss in Occupational Exposure to Metallic Mercury. Environ. Res. 1998, 77, 173-177.

(81) Grandjean, P.; Weihe, P.; White, R. F.; Debes, F. Cognitive Performance of Children Prenatally Exposed to "Safe" Levels of Methylmercury. Environ. Res. 1998, 77, 165-172.

(82) Henriksson, J.; Tjälve, H. Uptake of Inorganic Mercury in the Olfactory Bulbs via Olfactory Pathways in Rats. Environ. Res. 1998, 77, 130-140.

(83) Mahaffey, K. R.; Mergler, D. Blood Levels of Total and Organic Mercury in Residents of the Upper St. Lawrence River Basin, Québec: Association with Age, Gender, and Fish Consumption. Environ. Res. 1998, 77, 104-114.

(84) Shenker, B. J.; Guo, T. L.; Shapiro, I. M. Low-Level Methylmercury Exposure Causes Human T-Cells to Undergo Apoptosis: Evidence of Mitochondrial Dysfunction. Environ. Res. 1998, 77, 149-159.

(85) Zhou, Y.; Ma, Z. Colorimetric Detection of $\mathrm{Hg}^{2+}$ by $\mathrm{Au}$ Nanoparticles Formed by $\mathrm{H}_{2} \mathrm{O}_{2}$ Reduction of $\mathrm{HAuCl}_{4}$ Using $\mathrm{Au}$ Nanoclusters as the Catalyst. Sensors Actuators B Chem. 2017, 241, 1063-1068.

(86) Tan, L.; Zhang, Y.; Qiang, H.; Li, Y.; Sun, J.; Hu, L.; Chen, Z. A Sensitive Hg(II) Colorimetric Sensor Based on Synergistic Catalytic Effect of Gold Nanoparticles and Hg. Sensors Actuators B Chem. 2016, 229, 686-691.

(87) Zhao, Y.; Gui, L.; Chen, Z. Colorimetric Detection of Hg 2+ Based on TargetMediated Growth of Gold Nanoparticles. Sensors Actuators B Chem. 2017, 241, $262-267$.

(88) Tian, K.; Siegel, G.; Tiwari, A. A Simple and Selective Colorimetric Mercury (II) Sensing System Based on Chitosan Stabilized Gold Nanoparticles and 2,6Pyridinedicarboxylic Acid. Mater. Sci. Eng. C 2017, 71, 195-199.

(89) Che, Y.; Wu, D.; Deng, C.; Liu, L.; Jia, D. 5-Bromoindole-3-Carboxaldehyde Ethylthiosemicarbazone for $\mathrm{Hg}$ (II) Sensing and Removal. Chem. Phys. Lett. 2016, 644, 171-175. 
(90) Angupillai, S.; Hwang, J.-Y.; Lee, J.-Y.; Rao, B. A.; Son, Y.-A. Efficient Rhodamine-Thiosemicarbazide-Based Colorimetric/fluorescent "Turn-On" Chemodosimeters for the Detection of $\mathrm{Hg}^{2+}$ in Aqueous Samples. Sensors Actuators B Chem. 2015, 214, 101-110.

(91) Song, K.; Mo, J.; Lu, C. Hg(II) Sensing Platforms with Improved Photostability: The Combination of Rhodamine Derived Chemosensors and up-Conversion Nanocrystals. Spectrochim. Acta Part A Mol. Biomol. Spectrosc. 2017, 179, 125131.

(92) Wan, D.; Li, Y.; Zhu, P. A Series of Emission "turn-On" Probes Derived from Rhodamine for $\mathrm{Hg}$ (II) Recognition and Sensing: Synthesis, Characterization and Performance. Sensors Actuators B Chem. 2015, 221, 1271-1278.

(93) Nutiu, R.; Li, Y. Structure-Switching Signaling Aptamers. J. Am. Chem. Soc. 2003, $125,4771$.

(94) Jun, W.; Kai, R.; Beijing, H. Synthesis and Sensing Behavior of Fluorescence "turnOn" Chemosensors Based on Rhodamine for Hg(II) Detection. Sensors Actuators B Chem. 2016, 224, 465-477.

(95) Ramette, R. W.; Sandell, E. B. Rhodamine B Equilibria. J. Am. Chem. Soc. 1956, $78,4872-4878$.

(96) Zhou, S.; Zhou, Z.-Q.; Zhao, X.-X.; Xiao, Y.-H.; Xi, G.; Liu, J.-T.; Zhao, B.-X. A Dansyl Based Fluorescence Chemosensor for $\mathrm{Hg}(\mathrm{II})$ and Its Application in the Complicated Environment Samples. Spectrochim. Acta Part A Mol. Biomol. Spectrosc. 2015, 148, 348-354.

(97) Srivastava, P.; Ali, R.; Razi, S. S.; Shahid, M.; Patnaik, S.; Misra, A. A Simple Blue Fluorescent Probe to Detect $\mathrm{Hg}^{2+}$ in Semiaqueous Environment by Intramolecular Charge Transfer Mechanism. Tetrahedron Lett. 2013, 54, 3688-3693.

(98) Wanichacheva, N.; Kumsorn, P.; Sangsuwan, R.; Kamkaew, A.; Lee, V. S.; Grudpan, K. A New Fluorescent Sensor Bearing Three Dansyl Fluorophores for Highly Sensitive and Selective Detection of mercury(II) Ions. Tetrahedron Lett. 2011, 52, 6133-6136.

(99) Li, H.-W.; Wang, B.; Dang, Y.-Q.; Li, L.; Wu, Y. A Highly Selective Fluorescent Sensor for Mercury Ions in Aqueous Solution: Detection Based on Target-Induced Aggregation. Sensors Actuators B Chem. 2010, 148, 49-53.

(100) Métivier, R.; Leray, I.; Valeur, B. Lead and Mercury Sensing by Calixarene-Based Fluoroionophores Bearing Two or Four Dansyl Fluorophores. Chem. - A Eur. J. 2004, 10, 4480-4490.

(101) Hudson, M. J.; Harwood, L. M.; Laventine, D. M.; Lewis, F. W. Use of Soft Heterocyclic N-Donor Ligands To Separate Actinides and Lanthanides. Inorg. Chem. 2013, 52, 3414-3428. 
(102) Bhattacharyya, A.; Mohapatra P.K.; Manchanda, V. K. Separation of Americium(III) and Europium(III) from Nitrate Medium Using a Binary Mixture of Cyanex-301 with N-donor Ligands. Solvent Extr. Ion Exch. 2006, 24, 1-17.

(103) Radioactive Waste Partitioning and Transmutation within Advanced Fuel Cycles: Achievements and Challenges. Prog. Part. Nucl. Phys. 2011, 66, 144-166.

(104) Ghosh, P.; Shukla, A. D.; Das, A. Cerium Ion-Induced Fluorescence Enhancement of a Tripodal Fluoroionophore. Tetrahedron Lett. 2002, 43, 7419-7422.

(105) Panak, P. J.; Geist, A. Complexation and Extraction of Trivalent Actinides and Lanthanides by Triazinylpyridine N-Donor Ligands. Chem. Rev. 2013, 113, 1199-1236.

(106) Demir, S.; Brune, N. K.; Van Humbeck, J. F.; Mason, J. A.; Plakhova, T. V.; Wang, S.; Tian, G.; Minasian, S. G.; Tyliszczak, T.; Yaita, T.; Kobayashi, T.; Kalmykov, S. N.; Shiwaku, H.; Shuh, D. K.; Long, J. R. Extraction of Lanthanide and Actinide Ions from Aqueous Mixtures Using a Carboxylic Acid-Functionalized Porous Aromatic Framework. ACS Cent. Sci. 2016, 2, 253-265.

(107) Edwards, A. C.; Wagner, C.; Geist, A.; Burton, N. A.; Sharrad, C. A.; Adams, R. W.; Pritchard, R. G.; Panak, P. J.; Whitehead, R. C.; Harwood, L. M. Exploring Electronic Effects on the Partitioning of actinides(III) from lanthanides(III) Using Functionalised Bis-Triazinyl Phenanthroline Ligands. Dalton Trans. 2016, 45, $18102-18112$

(108) Macerata, E.; Mossini, E.; Scaravaggi, S.; Mariani, M.; Mele, A.; Panzeri, W.; Boubals, N.; Berthon, L.; Charbonnel, M.-C.; Sansone, F.; Arduini, A.; Casnati, A. Hydrophilic Clicked 2,6-Bis-Triazolyl-Pyridines Endowed with High Actinide Selectivity and Radiochemical Stability: Toward a Closed Nuclear Fuel Cycle. J. Am. Chem. Soc. 2016, 138, 7232-7235.

(109) Geist, A.; Müllich, U.; Magnusson, D.; Kaden, P.; Modolo, G.; Wilden, A.; Zevaco, T. Actinide(III)/Lanthanide(III) Separation Via Selective Aqueous Complexation of Actinides(III) Using a Hydrophilic 2,6-Bis(1,2,4-Triazin-3-Yl)-Pyridine in Nitric Acid. Solvent Extr. Ion Exch. 2012, 30, 433-444.

(110) Zalupski, P. R.; Nash, K. L.; Martin, L. R. Thermodynamic Features of the Complexation of Neodymium(III) and Americium(III) by Lactate in Trifluoromethanesulfonate Media. J. Solut. Chem. 2010, 39, 1213-1229.

(111) Güllü, F.; Bayrakcı, M.; Kursunlu, A. N.; Yiğiter, Ş.; Ertul, Ş. Synthesis and Trivalent Lanthanide Ion Complexation Studies of New Macrocyclic Receptors Based Lactam Ionophores. J. Incl. Phenom. Macrocycl. Chem. 2014, 80, 303-312.

(112) Bekiari, V.; Judeinstein, P.; Lianos, P. A Sensitive Fluorescent Sensor of Lanthanide Ions. J. Lumin. 2003, 104, 13-15.

(113) Aoki, S.; Kawatani, H.; Goto, T.; Kimura, E.; Shiro, M. A Double-Functionalized Cyclen with Carbamoyl and Dansyl Groups (Cyclen $=1,4,7,10-$ 
Tetraazacyclododecane): A Selective Fluorescent Probe for $\mathrm{Y}^{3+}$ and $\mathrm{La}^{3+}$. J. Am. Chem. Soc. 2001, 123, 1123-132.

(114) Wietzke, R.; Mazzanti, M. Strong Intramolecular $[\pi]-[\pi]]$ Interactions Favor the Formation of 2:1 (L:M) Lanthanide Complexes of tris(2Benzimidazolylmethyl)amine. Chem. Commun. 1999, 209-210. 


\section{CHAPTER II}

\section{Remarkably selective $\mathrm{NH}_{4}{ }^{+}$binding and fluorescence sensing by tripodal}

tris(pyrazolyl) receptors derived from 1,3,5-triethylbenzene.

Tosin M. Jonah, Logesh Mathivathanan, Alexander N. Morozov, Alexander M. Mebel, Raphael G. Raptis and Konstantinos Kavallieratos*

Department of Chemistry and Biochemistry and the Biomolecular Sciences Institute, Florida International University, 11200 SW 8th St, Miami, FL 33199, USA

(New J. Chem. 2017, 41, 14835-14838: DOI: 10.1039/c7nj03213g) 


\subsection{ABSTRACT}

A tripodal fluorescent sensor for $\mathrm{NH}_{4}{ }^{+}$based on 1,3,5-triethylbenzene shows remarkable binding and sensing selectivity for $\mathrm{NH}_{4}^{+}$vs. $\mathrm{K}^{+}$. Fluorescence and NMR titrations reveal surprising differences in sensing properties and binding constants for the tris-(3,5-dimethyl)pyrazole 1 vs. the tris(3,5-diphenyl)pyrazole 2. The X-ray structure of 2. $\mathrm{NH}_{4}{ }^{+}$and DFT calculations for 1, 2 and their ammonium complexes highlight the role of ion pairing of $\mathrm{NH}_{4}{ }^{+}$with the $\mathrm{PF}_{6}{ }^{-}$counteranion, in explaining these differences.

\subsection{Introduction}

The design and synthesis of selective $\mathrm{NH}_{4}{ }^{+}$receptors and sensors is of biological and environmental importance. ${ }^{1}$ Synthetic $\mathrm{NH}_{4}{ }^{+}$receptors have found uses in measuring the urea and creatinine levels and in environmental applications. ${ }^{2-4}$ However, achieving selectivity for $\mathrm{NH}_{4}{ }^{+}$over $\mathrm{K}^{+}$remains a challenge due to their similar ionic radii (286 vs. 266 pm, respectively). ${ }^{5}$ Receptors that bind $\mathrm{NH}_{4}{ }^{+}$via hydrogen bonding, including crown ethers and nonactin derivatives, have been reported. $^{5-9}$ Some remarkable examples include a cryptand/crown ether system reported by Shim et al. that binds $\mathrm{NH}_{4}{ }^{+}$with a $\mathrm{K}_{\mathrm{a}}$ two orders of magnitude greater than that for $\mathrm{K}^{+}\left(\mathrm{K}_{\mathrm{a}, \mathrm{NH} 4}{ }^{+} / \mathrm{K}_{\mathrm{a}, \mathrm{K}^{+}}=2.3 \times 10^{2}\right)^{10 \mathrm{a}}$ and a cryptand family with preorganized tetrahedral donor sites developed by Lehn at al. with a $\mathrm{NH}_{4}{ }^{+} / \mathrm{K}^{+}$selectivity of up to $500 .{ }^{10 \mathrm{~b}}$ Tripodal 1,3,5-trisubstituted benzene frameworks have found application in supramolecular chemistry for cation and anion binding and sensing: ${ }^{11,12}$ A polyether cryptand-type receptor derived from 1,3,5-triethylbenzene has shown high sensitivity and selectivity for $\mathrm{NH}_{4}{ }^{+}$, comparable to nonactin in an 
ion-selective electrode; the high selectivity was ascribed to cation $-\pi$ interactions. ${ }^{13}$ Oxazolines derived from the analogous 1,3,5-trimethylbenzene framework, ${ }^{14,15}$ showed selective fluorescence response for $\mathrm{NH}_{4}{ }^{+}$over $\mathrm{K}^{+}, \mathrm{Na}^{+}$, and $\mathrm{Mg}^{2+}$ in the 305$340 \mathrm{~nm}$ range $\left(\lambda_{\mathrm{exc}}=272 \mathrm{~nm}\right)$. Tripodal pyrazoles have been reported as redoxactivated MRI contrast agents, ${ }^{16}$ and ion-selective electrodes modified with tripodal pyrazolyl $^{17}$ analogs, such as 1,3,5-tris-(3,5-dimethylpyrazolyl)-2,4,6-triethyl benzene (1), have shown selectivity for $\mathrm{NH}_{4}^{+}$over $\mathrm{K}^{+}$. However, $\mathrm{NMR}$ and fluorescence studies of $\mathrm{NH}_{4}{ }^{+}$binding with pyrazolyl hosts have not been previously undertaken.

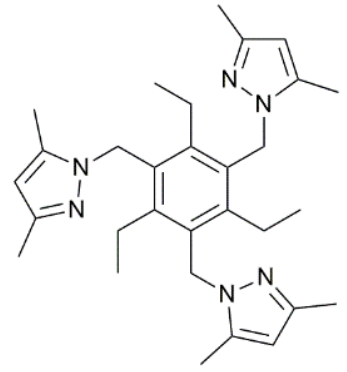

1

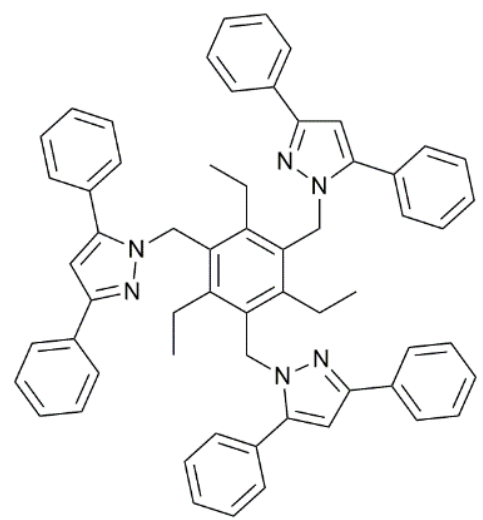

2

Figure 2.1. Chemical structure of ligands 1 and 2.

Herein, we report a new pyrazole receptor (2), based on the 1,3,5-triethylbenzene framework, and for the first time selective fluorescence sensing of $\mathrm{NH}_{4}{ }^{+} v s . \mathrm{K}^{+}$by any pyrazole-type receptor. ${ }^{1} \mathrm{H}-\mathrm{NMR}$ titrations reveal remarkable binding strength and selectivity for $\mathrm{NH}_{4}^{+}$over $\mathrm{K}^{+}$for $\mathbf{1}$, and a surprising difference in binding constants between trispyrazoles $\mathbf{1}$ and 2 . The X-ray structure of $\mathbf{2} \mathrm{NH}_{4}{ }^{+}$and DFT calculations for $\mathbf{1}, 2$ and their corresponding $\mathrm{NH}_{4}{ }^{+}$complexes provide consistent 
information related to the lack of ion pairing of $\mathrm{NH}_{4}{ }^{+}$with the $\mathrm{PF}_{6}{ }^{-}$counteranion for $\mathbf{2}$ that may explain the dramatic $\mathrm{NH}_{4}{ }^{+}$binding differences between $\mathbf{1}$ and $\mathbf{2}$.

\subsection{Results and Discussion}

Both compounds were prepared by modification of previously reported methods. ${ }^{17,18}$ Fluorescence titrations of $\mathbf{1}$ and $\mathbf{2}$ with $\mathrm{NH}_{4} \mathrm{PF}_{6}$ at constant receptor concentration $\left(1.0 \times 10^{-4} \mathrm{M}\right)$ were carried out in $\mathrm{CH}_{3} \mathrm{CN} / \mathrm{CH}_{2} \mathrm{Cl}_{2}(1: 1)$ with $\lambda_{\mathrm{exc}}=272$ $\mathrm{nm}$ for $\mathbf{1}$ and $\lambda_{\mathrm{exc}}=262 \mathrm{~nm}$ for $\mathbf{2}$. Addition of $\mathrm{NH}_{4} \mathrm{PF}_{6}$ to tris-(3,5-dimethylpyrazole) 1 showed an increase in fluorescence upon cation binding, which is significantly higher for $\mathrm{NH}_{4}{ }^{+} v s . \mathrm{K}^{+}$(Fig. 2.2), a pattern similar to the one observed for analogous tripodal oxazolines. ${ }^{15}$ The diphenyl analog 2 did not show such increases and instead showed fluorescence quenching (Fig 2.3). This sharp difference in sensing behavior between the dimethyl and diphenyl analogy is striking.

The cation binding properties of $\mathbf{1}$ and $\mathbf{2}$ were determined in acetone- $\mathrm{d}_{6}$ by ${ }^{1} \mathrm{H}-$ NMR titrations with $\mathrm{M}^{+} \mathrm{PF}_{6}^{-}\left(\mathrm{M}^{+}=\mathrm{NH}_{4}^{+}\right.$, $\mathrm{K}^{+}$, Fig. 2.4). The association constants for the formation of 1:1 complex $\left(\mathrm{K}_{\mathrm{a}}\right)$, were determined by non-linear regression analysis using the 1:1 binding isotherm. For 1, downfield shifts for all proton resonances were observed except for the $-\mathrm{CH}_{2-}$ of the ethyl group, which shifted upfield. Non-linear regression analysis of the binding isotherms obtained from these shifts gave a 1:1 association constant $K_{a}$ of $74000( \pm 900) \mathrm{M}^{-1}$ for the formation of 1. $\mathrm{NH}_{4}{ }^{+}$and a $\mathrm{K}_{\mathrm{a}}$ of $22 \mathrm{M}^{-1}( \pm 1)$ for $\mathbf{1} \cdot \mathrm{K}^{+}$. In order to include $\mathrm{Na}^{+}$in the comparison, and due to the limited solubility of $\mathrm{NaPF}_{6}$ in acetone- $\mathrm{d}_{6}$, the experiments were repeated in $\mathrm{CD}_{3} \mathrm{OD}$ (Fig. 2.5). The association constants, $\mathrm{K}_{\mathrm{a}}$ obtained by NMR show 
the preference of 1 for $\mathrm{NH}_{4}^{+}\left(\mathrm{K}_{\mathrm{a}}=163 \mathrm{M}^{-1}\right)$ over $\mathrm{Na}^{+}\left(\mathrm{K}_{\mathrm{a}}=4 \mathrm{M}^{-1}\right)$ and $\mathrm{K}^{+}$(for which the chemical shift changes were too small to give a reliable binding curve fit).

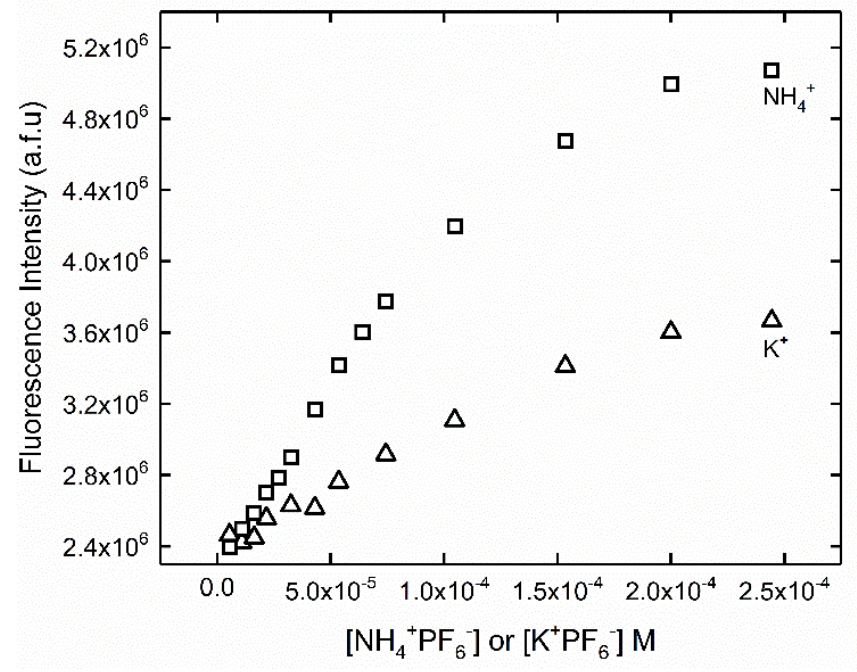

Figure 2.2. Fluorescence titration $\left(\lambda_{\mathrm{exc}}=272 \mathrm{~nm}\right)$ of $1\left(1.0 \times 10^{-4} \mathrm{M}\right)$ with $\mathrm{NH}_{4}{ }^{+} \mathrm{PF}_{6}{ }^{-}$or $\mathrm{K}^{+} \mathrm{PF}_{6}{ }^{-}$in $\mathrm{CH}_{3} \mathrm{CN} / \mathrm{CH}_{2} \mathrm{Cl}_{2}$ (1:1).

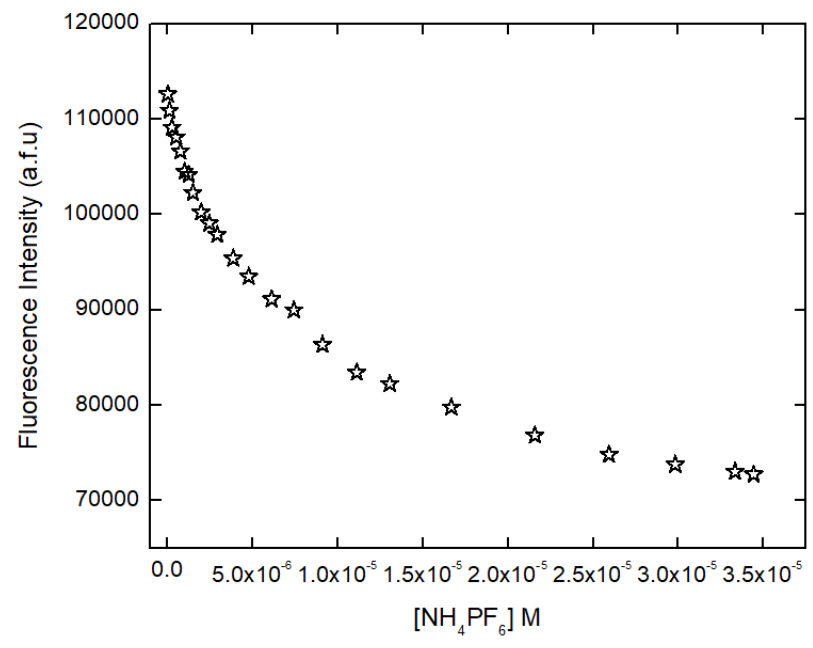

Figure 2.3. Fluorescence titration $\left(\lambda_{\mathrm{exc}}=262 \mathrm{~nm}\right)$ of 2 with $\mathrm{NH}_{4}{ }^{+} \mathrm{PF}_{6}{ }^{-}$in $\left(\mathrm{CH}_{3} \mathrm{CN} / \mathrm{CH}_{2} \mathrm{Cl}_{2}\right.$ (1:1). 


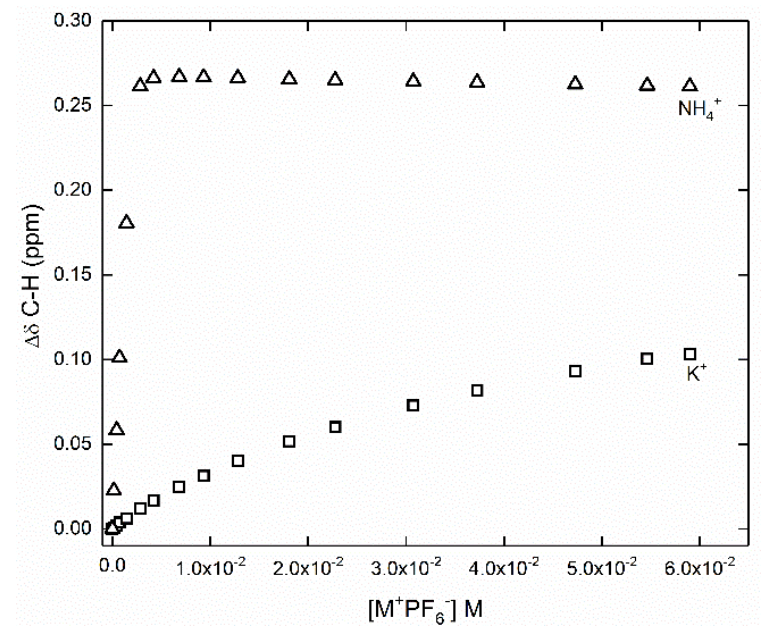

Figure 2.4. ${ }^{1} \mathrm{H}-\mathrm{NMR}$ titration plot of 1 (for $\mathrm{CH}_{3} \mathrm{CH}_{2}$ ) with $\mathrm{M}^{+} \mathrm{PF}_{6}^{-}\left(\mathrm{M}^{+}=\mathrm{NH}_{4}^{+}, \mathrm{K}^{+}\right.$) in acetone- $\mathrm{d}_{6}$. The concentration of 1 was kept constant at $2 \mathrm{mM}$.

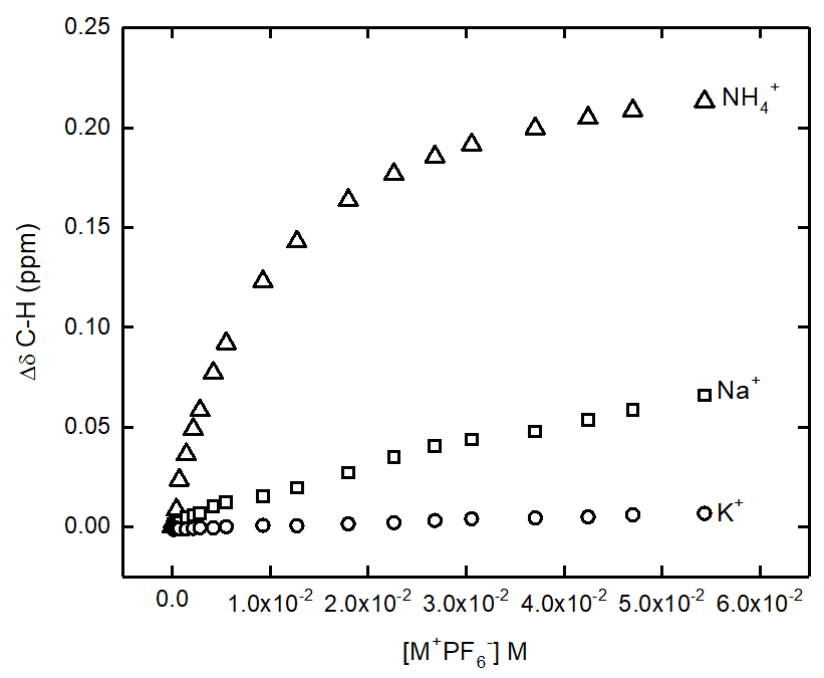

Figure 2.5. ${ }^{1} \mathrm{H}-\mathrm{NMR}$ titration of 1 with $\mathrm{M}^{+} \mathrm{PF}_{6}{ }^{-}$in $\mathrm{CD}_{3} \mathrm{OD}\left(\mathrm{M}=\mathrm{NH}_{4}{ }^{+}, \mathrm{Na}^{+}\right.$, or $\left.\mathrm{K}^{+}\right)$. The concentration of 1 was kept constant at $2 \mathrm{mM}$.

For 2, (unlike for 1) the $\mathrm{CH}_{3}$ protons of the ethyl group shift downfield upon addition of $\mathrm{NH}_{4} \mathrm{PF}_{6}$ instead of upfield. The association constant for the $2 \mathrm{NH}_{4}{ }^{+}$ complex in acetone- $\mathrm{d}_{6}$ was found to be only $15 \mathrm{M}^{-1}$, which is almost four orders of magnitude lower than those of the dimethyl analog 1. This dramatic difference in binding cannot be simply explained by electronic and steric effects, as the cavity of 
the tris(diphenyl)pyrazole can comfortably accommodate the $\mathrm{NH}_{4}{ }^{+}$(as seen in the X-ray structure). The 1:1 complexation stoichiometry indicated by the titration curve fits, was also verified by the continuous variation method ${ }^{19}$ with Job plot maxima at mol fraction of 0.5 for both 1 and 2 (Fig. $2.6 \& 2.7$ ).

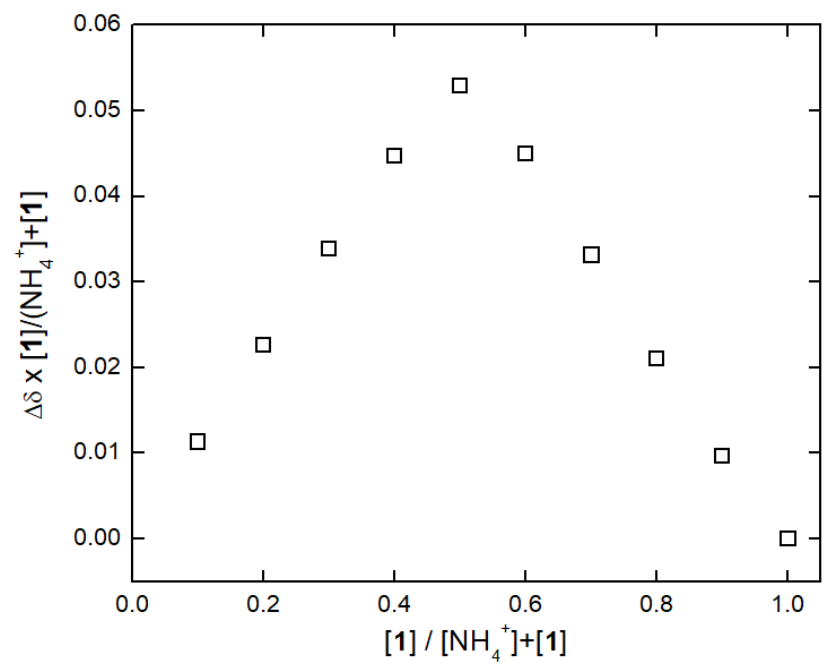

Figure 2.6. Jobs plot of $1\left(\mathrm{CH}_{3} \mathrm{CH}_{2}-\right)$ with $\mathrm{NH}_{4}{ }^{+} \mathrm{PF}_{6}{ }^{-}$in acetone- $\mathrm{d}_{6} .0 .002 \mathrm{M}$ Stock solutions of 1 and $\mathrm{NH}_{4}{ }^{+} \mathrm{PF}_{6}{ }^{-}$were used.

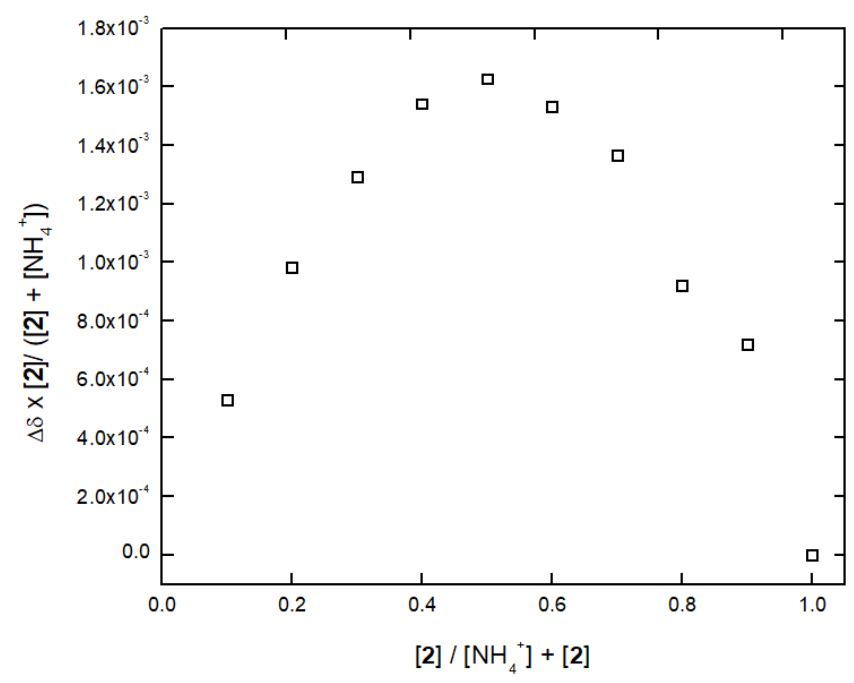

Figure 2.7. Jobs plot for 2 with $\mathrm{NH}_{4}{ }^{+} \mathrm{PF}_{6}{ }^{-}$in acetone- $\mathrm{d}_{6} .0 .002 \mathrm{M}$ Stock solutions of 2 and $\mathrm{NH}_{4}{ }^{+} \mathrm{PF}_{6}^{-}$were used. 
X-ray structural analysis of the crystals of $\left[\mathbf{2} \cdot \mathrm{NH}_{4}\right]^{+} \mathrm{PF}_{6}^{-}$(Fig. $2.8 \& 2.9$ ) obtained by diffusion of $\mathrm{Et}_{2} \mathrm{O}$ into a methanol solution of 2 and $\mathrm{NH}_{4}{ }^{+} \mathrm{PF}_{6}{ }^{-}$(1:1 molar ratio) shows important similarities and differences with the $\left[1 \cdot \mathrm{NH}_{4}\right]^{+} \mathrm{PF}_{6}^{-} \mathrm{X}$-ray structure previously published by Chin et al. ${ }^{17 \mathrm{~b}}$ All three pyrazole rings are directed towards the bound $\mathrm{NH}_{4}{ }^{+}$, but unlike the X-ray structure of $\left[\mathbf{1} \cdot \mathrm{NH}_{4}\right]{ }^{+} \mathrm{PF}_{6}{ }^{-}$all three ethyl groups are now directed on the opposite side of the central aromatic ring. A crystallographic 3-fold symmetry axis now runs through the ammonium $\mathrm{N}$-atom and the aromatic centroid. The three symmetryrelated H-bonded N...N distances between the ammonium and the pyrazole are 2.950(2) $\AA$, indicating strong hydrogen bonding. In the published structure of $\left[\mathbf{1} \cdot \mathrm{NH}_{4}\right]^{+} \mathrm{PF}_{6}^{-}$ however, ${ }^{17 \mathrm{~b}}$ the three N...N distances of 2.948(5) $\AA, 3.001(4) \AA$, and 3.053(4) $\AA$ are longer - on average, 3.00(4) $\AA$. Both $\left[\mathbf{2} \cdot \mathrm{NH}_{4}\right]^{+} \mathrm{PF}_{6}^{-}$and $\left[\mathbf{1} \cdot \mathrm{NH}_{4}\right]^{+} \mathrm{PF}_{6}{ }^{-}$show cation- $\pi$ interactions between $\mathrm{NH}_{4}{ }^{+}$and the central aromatic ring, with the $\left[2 \cdot \mathrm{NH}_{4}\right]^{+} \mathrm{PF}_{6}{ }^{-}$structure showing a slightly stronger interaction with an N-centroid distance of 3.030(6) $\AA$ vs. 3.131(3) $\AA$ in $\left[\mathbf{1} \cdot \mathrm{NH}_{4}\right]^{+} \mathrm{PF}_{6}{ }^{-}$. The small difference in the $\mathrm{N}-\mathrm{H}^{\cdots} \mathrm{N}$ distances between $\left[\mathbf{1} \cdot \mathrm{NH}_{4}\right]^{+} \mathrm{PF}_{6}^{-}$and $\left[2 \cdot \mathrm{NH}_{4}\right]^{+} \mathrm{PF}_{6}^{-}$indicates that neither the strength of the hydrogen bonding interaction between ammonium and $\mathbf{1}$ or $\mathbf{2}$, nor the differences in cation- $\pi$ interactions, can explain the remarkable four orders of magnitude difference in the binding affinities of these ligands with $\mathrm{NH}_{4}{ }^{+}$. On the contrary, both the $\mathrm{H}$-bonding distances and the $\mathrm{N}$-centroid distances suggest that $\mathbf{2}$ should bind $\mathrm{NH}_{4}{ }^{+}$stronger than $\mathbf{1}$, which is in direct contrast to the measured NMR binding constants. However, a key observation in the crystal structure of $\left[2 \cdot \mathrm{NH}_{4}\right]^{+} \mathrm{PF}_{6}{ }^{-}$may explain this discrepancy: The lack of any interaction between the complexed $\mathrm{NH}_{4}{ }^{+}$and the $\mathrm{PF}_{6}{ }^{-}$counteranion, presumably because the $\mathrm{NH}_{4}{ }^{+}$cation is "buried" among the phenyl rings of the pyrazoles, prevents the approach of $\mathrm{PF}_{6}$, leading 
to a well-separated ion pair. This is unlike the crystal structure of $\left[\mathbf{1} \cdot \mathrm{NH}_{4}\right]^{+} \mathrm{PF}_{6}{ }^{-17 \mathrm{~b}}$ which shows weak $\mathrm{H}$-bonding between the complexed $\mathrm{NH}_{4}{ }^{+}$and the $\mathrm{F}$ of the $\mathrm{PF}_{6}{ }^{-}$counteranion (F...N distance of 3.031(4) $\AA$ ). This difference between $\mathbf{1}$ and $\mathbf{2}$ in facilitating ion pairing between $\mathrm{NH}_{4}{ }^{+}$and $\mathrm{PF}_{6}{ }^{-}$can explain the binding constant trends, as the thermodynamic contribution of second-sphere coordination ${ }^{20-21}$ to overall binding by ion pair interactions is very substantial. ${ }^{22-25}$
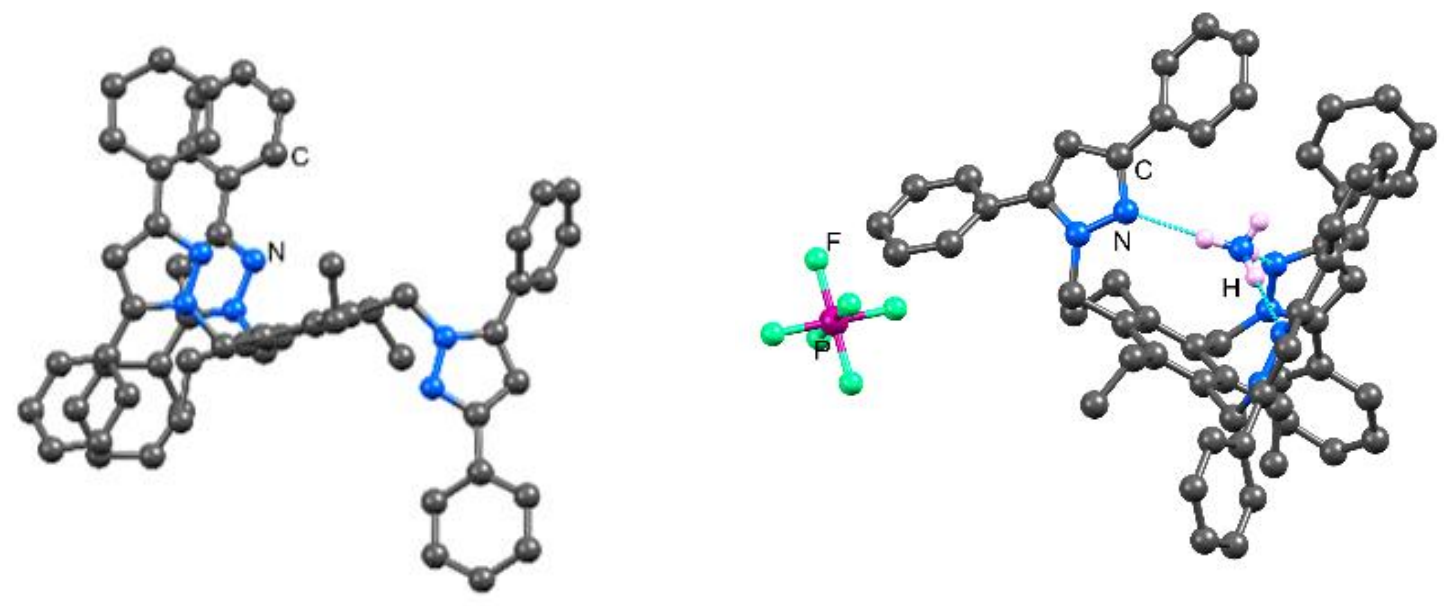

Figure 2.8. Crystal structure of [2] (left) vs. 2. $\mathrm{NH}_{4} \mathrm{PF}_{6}$ (right). H-atoms and disorders on phenyl rings are not shown for clarity.
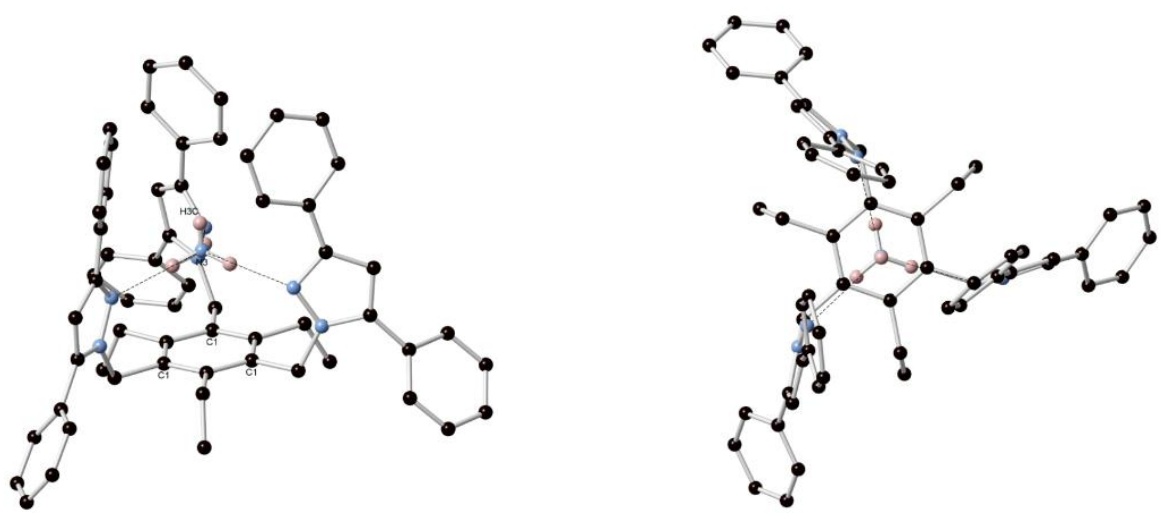

Figure 2.9. Crystal structure of $\left[\mathbf{2} \cdot \mathrm{NH}_{4}{ }^{+}\right] \mathrm{PF}_{6}{ }^{-}$showing $\mathrm{NH}_{4}{ }^{+} \mathrm{H}$-bonded to the 2 host. $\mathrm{N}(\mathrm{pz}) \cdots \mathrm{N}\left(\mathrm{NH}_{4}\right)$ distance: $2.950(3) \AA$. The disordered $\mathrm{PF}_{6}{ }^{-}$is not shown for clarity. 
In order to further understand the $\mathrm{NH}_{4}{ }^{+}$binding properties for $\mathbf{1}$ and $\mathbf{2}$ and the roles of ion pairing and solvation $v s$. chelation, ${ }^{26}$ DFT $6-31 G^{* *} / \mathrm{B} 3 \mathrm{LYP}$ calculations of Gibbs free energies $(\Delta \mathrm{G})$ for $\mathrm{NH}_{4}^{+}, \mathrm{PF}_{6}^{-}, \mathbf{L},\left[\mathbf{L} \cdot \mathrm{NH}_{4}\right]^{+}$and $\left[\mathbf{L} \cdot \mathrm{NH}_{4}\right]^{+} \mathrm{PF}_{6}^{-}(\mathbf{L}=\mathbf{1}$, 2) were conducted. In the gas phase, the complex formation reaction $\mathbf{L}+\mathrm{NH}_{4}{ }^{+} \rightarrow$ $\left[\mathbf{L} \cdot \mathrm{NH}_{4}\right]^{+}$is exergonic by $-60.8 \mathrm{kcal} / \mathrm{mol}$ and $-61.9 \mathrm{kcal} / \mathrm{mol}$ for $\mathbf{1}$ and $\mathbf{2}$, respectively at ambient temperature. When acetone solvation is taken into account, the corresponding $\Delta \mathrm{G}$ values change to $-12.2 \mathrm{kcal} / \mathrm{mol}$ and $-9.3 \mathrm{kcal} / \mathrm{mol}$, respectively. The DFT results are in line with the experimental data and indicate that solvation effect decisively contributes to the measured difference in $\mathrm{NH}_{4}{ }^{+}$binding by $\mathbf{1}$ and $\mathbf{2}$. The $\left[\mathbf{2} \cdot \mathrm{NH}_{4}\right]^{+}$complex creates a larger cavity in solvent than $\left[\mathbf{1} \cdot \mathrm{NH}_{4}\right]^{+}$, making solvation less favorable. The calculated $\Delta G$ for the formation of $\left[\mathbf{1} \cdot \mathrm{NH}_{4}\right]^{+} \mathrm{PF}_{6}{ }^{-}$is exergonic both in the gas phase $(-68.2 \mathrm{kcal} / \mathrm{mol})$ and in acetone $(-0.8 \mathrm{kcal} / \mathrm{mol})$. This agrees with the presence of ion pairing in the crystal structure. ${ }^{17 b}$ Alternatively, the $\Delta G$ for the formation of $\left[\mathbf{2} \cdot \mathrm{NH}_{4}\right]^{+} \mathrm{PF}_{6}$ is exergonic in the gas phase $(-43.8 \mathrm{kcal} / \mathrm{mol})$, but endergonic in acetone $(8.2 \mathrm{kcal} / \mathrm{mol})$, which again agrees with the absence of ion pairing in the $\left[2 \cdot \mathrm{NH}_{4}\right]^{+} \mathrm{PF}_{6}{ }^{-}$crystal structure. Thus, the DFT results (Fig. 2.11) corroborate our hypothesis that the lack of ion pairing ${ }^{25 \mathrm{~b}}$ in $\left[2 \cdot \mathrm{NH}_{4}\right]^{+} \mathrm{PF}_{6}^{-}$strongly contributes to the observed difference in the $\mathrm{NH}_{4}{ }^{+}$binding properties between 1 and 2.

\subsection{Conclusion}

In conclusion, selective $\mathrm{NH}_{4}{ }^{+}$binding and fluorescence sensing by tripodal pyrazolyl receptors were demonstrated. Spectroscopic studies in solution, X-ray structural information, and DFT calculations all point to the importance of ion pairing and solvation 
in determining binding strength and selectivity, with pyrazole substitution leading to remarkable differences. We are currently probing the binding properties of these ligand platforms by further structural, spectroscopic and theoretical investigations involving other ion pairs.

\subsection{Experimental Section}

\subsubsection{Materials and Methods}

All chemicals were purchased from Aldrich Chemical Company or ACROS Organics, were standard reagent grade and were used without further purification unless otherwise noted. 1,3,5-trisbromomethyl-2,4,6-triethylbenzene was either purchased from Aldrich Chemicals, or synthesized as previously reported. ${ }^{27}$ The tris-(pyrazolyl) ammonium receptor 1 was prepared from 1,3,5-tris-(bromomethyl)-2,4,6-triethylbenzene, $\mathrm{NaH}$ and 3,5-dimethylpyrazole, according to a previously published procedure, and was found spectroscopically to be identical to the reported compound. ${ }^{17 \mathrm{~b}} \quad{ }^{1} \mathrm{H}$ and ${ }^{13} \mathrm{C}$ NMR spectra were recorded on a $400 \mathrm{MHz}$ Bruker NMR spectrometer and were referenced to the residual solvent resonance. All chemical shifts, $\delta$, are reported in ppm. Fluorescence spectra were recorded on a Jobin-Yvon Horiba Fluoromax-3 instrument, or a Photon Technologies Model PTI- QuantaMaster UV-Vis QM-4 steady state spectrofluorometer. Elemental analysis was obtained at Galbraith Labs, Knoxville, TN.

\subsubsection{Synthesis of 1,3,5- tris(3,5-diphenyl-1H-pyrazole) -2,4,6-triethylbenzene (2)}

The tris-(3,5-diphenyl) analog $\mathbf{2}$ was synthesized as described below by a modification of a previously published procedure by Arunachalam et al. ${ }^{28} \mathrm{NaOH}(72 \mathrm{mg}, 1.81 \mathrm{mmoL})$ was disolved in $5 \mathrm{~mL}$ of DMF (dried with 4A molecular sieves). 3,5-diphenyl pyrazole 
(398 $\mathrm{mg} 1.81 \mathrm{mmoL}$ ) was added to the stirring solution and was allowed to react for 30 min, at room temperature. 1,3,5-tris(bromomethyl)-2,4,6 triethylbenzene (198 $\mathrm{mg}, 0.45$ mmoL) was added to the resulting solution and the reaction mixture was stirred for $48 \mathrm{~h}$ at $70{ }^{\circ} \mathrm{C}$ under $\mathrm{N}_{2}$. The reaction was allowed to cool to room temperature and then poured into ice/water. The formed solid was filtered, dried, and recrystallized from dichloromethane/hexane. Further purification by silica column chromatography EtOAc/Hexane (1:9) gave $350 \mathrm{mg}$ of the pure product (yield, 90\%). ${ }^{1} \mathrm{H}$ NMR (400 MHz, acetone-d $\left._{6}\right) \delta 7.75(\mathrm{~d}, J=6.7 \mathrm{~Hz}, 6 \mathrm{H}), 7.58(\mathrm{~d}, J=6.6 \mathrm{~Hz}, 6 \mathrm{H}), 7.54-7.38(\mathrm{~m}, 9 \mathrm{H}), 7.39$ - $7.10(\mathrm{~m}, 9 \mathrm{H}), 6.74(\mathrm{~s}, 3 \mathrm{H}), 5.39(\mathrm{~s}, 6 \mathrm{H}), 2.65(\mathrm{q}, J=7.5 \mathrm{~Hz}, 6 \mathrm{H}), 0.67(\mathrm{t}, J=7.5 \mathrm{~Hz}, 9 \mathrm{H})$. ${ }^{13} \mathrm{C}-\mathrm{NMR}(400 \mathrm{MHz}$, acetone-d $) . \quad \delta 150.2,144.2,135.5,130.5,128.7,129.2,127.5,10.0$, 52.1, 23.8, 15.1. Anal. Cald. For $\mathrm{C}_{60} \mathrm{H}_{54} \mathrm{~N}_{6}:$ C, 83.80, H, 6.34, N, 9.78, Found C, 83.70, H, 6.32, N, 9.66.
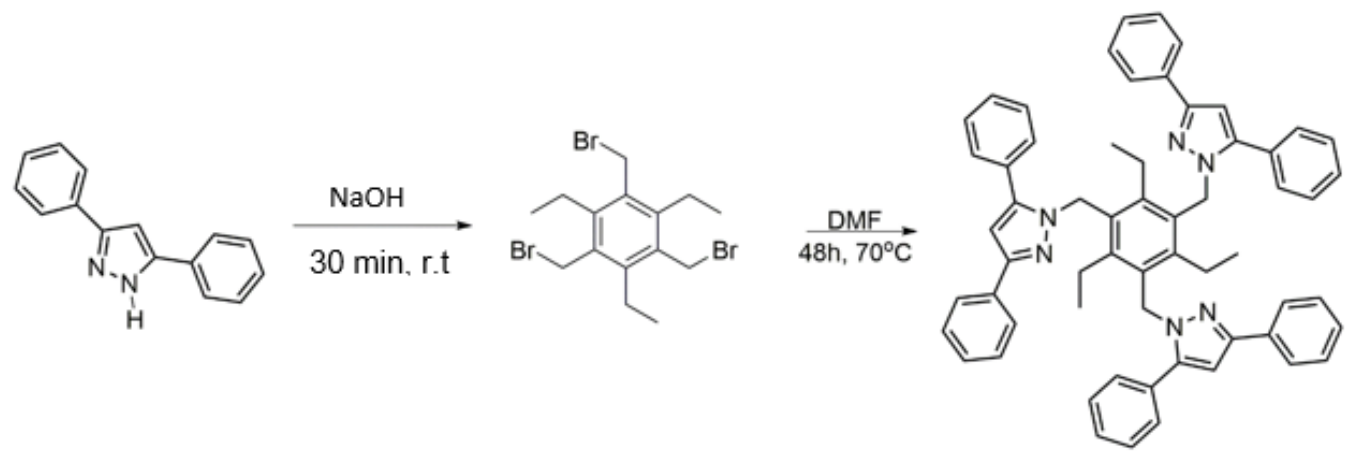

Scheme 2.1. Synthesis of receptor 2

\subsubsection{Fluorescence titrations}

Fluorescence titrations were performed in solutions of constant concentration of receptors 1 or 2 with $\mathrm{KPF}_{6}$, and $\mathrm{NH}_{4} \mathrm{PF}_{6}$. Fluorescence emission was measured at 
increments of $0.5 \mathrm{~nm}$, and integration time of $0.1 \mathrm{~s}$, excitation slit width of $10 \mathrm{~nm}$, emission slit width of $5 \mathrm{~nm}$. For $\mathbf{1}$, the emission was measured at $298 \mathrm{~nm}\left(\lambda_{\mathrm{exc}}=272 \mathrm{~nm}\right)$ and for $\mathbf{2}$, the emission was measured at $335 \mathrm{~nm}\left(\lambda_{\mathrm{exc}}=262 \mathrm{~nm}\right)$. In a typical experiment, solution A $\left(1.0 \times 10^{-4} \mathrm{M}\right)$ in $\mathrm{CH}_{3} \mathrm{CN} / \mathrm{CH}_{2} \mathrm{Cl}_{2}(1: 1)$ of receptor 2 was titrated with solution $\mathrm{B}$ of with $\mathrm{NH}_{4}{ }^{+} \mathrm{PF}_{6}{ }^{-}\left(1.0 \times 10^{-2} \mathrm{M}\right)$. Solution $\mathrm{B}$ was prepared by dilutions with solution A, thus keeping a constant concentration of $\mathbf{2}$ upon titration of solution A with solution B. $2.0 \mathrm{~mL}$ of solution A were added to the fluorescence cuvette and solution B was added in increments until a total of $1000 \mu \mathrm{L}$. Figure 2.3 shows the results for fluorescence titration of ligand 2 with $\mathrm{NH}_{4}{ }^{+} \mathrm{PF}_{6}{ }^{-}$indicating fluorescence quenching.

\subsection{4. ${ }^{1} \mathrm{H}-\mathrm{NMR}$ Titration Experiments}

The association constants ${ }^{19,29}$ for the formation of cation-receptor complexes were determined by titration of solutions of $\mathbf{1}$ or $\mathbf{2}$ in acetone- $\mathrm{d}_{6}$ ( for $\mathrm{NH}_{4}{ }^{+} \mathrm{PF}_{6}^{-}$and $\mathrm{K}^{+} \mathrm{PF}_{6}^{-}$) or methanol- $\mathrm{d}_{4}$, for all salts $\left(2 \times 10^{-3} \mathrm{M}\right.$ - solution A) with solutions of $\mathrm{NH}_{4}{ }^{+} \mathrm{PF}_{6}{ }^{-}\left(1.0 \times 10^{-1}\right)$ $\mathrm{K}^{+} \mathrm{PF}_{6}^{-}\left(1.0 \times 10^{-1}\right)$, or $\mathrm{Na}^{+} \mathrm{PF}_{6}^{-}(0.5 \mathrm{M})$ in the same receptor concentration (solution $\mathrm{B}$ ). Solution B was prepared by dilutions with solution A, thus keeping a constant concentration of $\mathbf{1}$ or $\mathbf{2}$ upon titration of solution A with solution B. In a typical experiment, solution A $(0.700 \mathrm{~mL})$ was placed in an NMR tube. Solution B was added in increments with a $\mu \mathrm{L}$ syringe until a total of $950 \mu \mathrm{L}$ was added. The chemical shift changes were monitored, with the results plotted and fitted to the 1:1 binding isotherm (Eq.1) using nonlinear regression analysis:

$$
\left.\Delta \delta=\delta_{\text {obs }}-\delta_{2}=\left([\mathbf{R}]_{\mathrm{t}}+\left[\mathrm{X}^{-}\right]_{\mathrm{t}}+\mathrm{K}_{\mathrm{a}}^{-1}-\left(\left(\left([\mathbf{R}]_{\mathrm{t}}+\left[\mathrm{X}^{-}\right]_{\mathrm{t}}+\mathrm{K}_{\mathrm{a}}^{-1}\right)^{2}-4\left[\mathrm{X}^{-}\right]_{\mathrm{t}}[\mathbf{R}]_{\mathrm{t}}\right)^{1 / 2}\right)\right) \Delta \delta_{\max }\right)
$$

$/\left(2[\mathbf{R}]_{\mathrm{t}}\right)($ Eq. 1$)$ 


\subsubsection{Continuous Variation Method (Jobs plots):}

Stock solutions of the receptors 1 or $2(0.002 \mathrm{M})$ and $\mathrm{NH}_{4}{ }^{+} \mathrm{PF}_{6}{ }^{-}(0.002 \mathrm{M})$ in acetone- $\mathrm{d}_{6}$ were prepared. Ten NMR tubes were filled with $500 \mu \mathrm{l}$ solutions of the host and guest in the following volume ratios (in $\mu 1$ ).500:0, 450:50, 400:100, 350:150, 300:200, 250:250, 200: 300,150:350, 100:400, 50:450. ${ }^{1} \mathrm{H}-\mathrm{NMR}$ spectra were recorded and jobs plot was obtained by plotting against $[\mathbf{L}] /\left(\left[\mathrm{NH}_{4}{ }^{+}\right]+[\mathbf{L}]\right.$ ) (where $\mathbf{L}$ is receptor $\mathbf{1}$ or $\mathbf{2}$ ). Jobs plot curve maxima at mol. fraction of 0.5 were observed for host:guest indicating a 1:1 complex stoichiometry.

\subsubsection{Computational Details.}

DFT calculations of the gas phase molecular structures were carried out without symmetry restrictions using the $\mathrm{B} 3 \mathrm{LYP}^{30-31}$ hybrid density functional (B3LYP) with the double- 6$31 \mathrm{G}^{* *}$ basis set for $\mathrm{H}, \mathrm{C}, \mathrm{N}, \mathrm{O}, \mathrm{F}^{32}$ and $\mathrm{P}^{33}$ atoms (basis set $\mathrm{B} 0$ ). Stability checks, optimizations, frequency and hydration energy calculations with basis set B0 were performed using Gaussian-09. ${ }^{34}$ All optimized molecular structures have only real frequencies. The calculated frequencies were used to obtain free energies at room temperature. Solvent contributions to the gas-phase free energies were estimated as singlepoint hydration energy for a gas-phase optimized molecular structure within the self-

consistent reaction field (SCRF) using $\mathrm{PCM}^{35}$ model with Gaussian-09 ${ }^{34}$ default parameters for acetone. 


\subsubsection{1. $\quad \mathrm{L}+\mathrm{NH}_{4}{ }^{+} \rightarrow\left[\mathrm{L} \cdot \mathrm{NH}_{4}+\right]$}

The calculated free energy of $\mathbf{1}+\mathrm{NH}_{4}{ }^{+} \rightarrow\left[\mathbf{1} \cdot \mathrm{NH}_{4}{ }^{+}\right]$gas phase complexation is -60.8 $\mathrm{kcal} / \mathrm{mol}$.

The calculated free energy of $[\mathbf{1}]_{\text {acetone }}+\left[\mathrm{NH}_{4}\right]^{+}$acetone $\rightarrow\left[\mathbf{1} \cdot \mathrm{NH}_{4}\right]^{+}$acetone complexation is $12.2 \mathrm{kcal} / \mathrm{mol}$.

The calculated free energy of $\mathbf{2}+\mathrm{NH}_{4}{ }^{+} \rightarrow\left[\mathbf{2} \cdot \mathrm{NH}_{4}\right]^{+}$gas phase complexation is -61.9 $\mathrm{kcal} / \mathrm{mol}$.

The calculated free energy of $[\mathbf{1}]_{\text {acetone }}+\left[\mathrm{NH}_{4}\right]^{+}{ }_{\text {acetone }} \rightarrow\left[\mathbf{1} \cdot \mathrm{NH}_{4}\right]^{+}$acetone complexation is $-9.3 \mathrm{kcal} / \mathrm{mol}$.

\subsubsection{2. $\quad\left[\mathrm{L} . \mathrm{NH}_{4}\right]^{+}+\mathrm{PF}_{6}{ }^{-} \rightarrow\left[\mathrm{L} \cdot \mathrm{NH}_{4}\right]^{+} \mathrm{PF}_{6}{ }^{-}$}

The calculated free energy of $\left[\mathbf{1} \cdot \mathrm{NH}_{4}\right]^{+}+\mathrm{PF}_{6}{ }^{-} \rightarrow\left[\mathbf{1} \cdot \mathrm{NH}_{4}\right]^{+} \mathrm{PF}_{6}{ }^{-}$gas phase complexation is $-68.2 \mathrm{kcal} / \mathrm{mol}$. The optimized molecular structure of $\left[\mathbf{1} \cdot \mathrm{NH}_{4}\right]^{+} \mathrm{PF}_{6}^{-}$has $\mathrm{C}_{3}$ symmetry with 3-fold axis running through the phenyl ring, $\mathrm{N}$ of the $\mathrm{NH}_{4}{ }^{+}$and $\mathrm{P}$ of $\mathrm{PF}_{6}$. The calculated free energy of $\left[\mathbf{1} \cdot \mathrm{NH}_{4}\right]^{+}$acetone $+\left[\mathrm{PF}_{6}\right]^{-}$acetone $\rightarrow\left[\left[\mathbf{1} \cdot \mathrm{NH}_{4}\right]^{+} \mathrm{PF}_{6}^{-}\right]_{\text {acetone }}$ complexation is -0.8 $\mathrm{kcal} / \mathrm{mol}$.

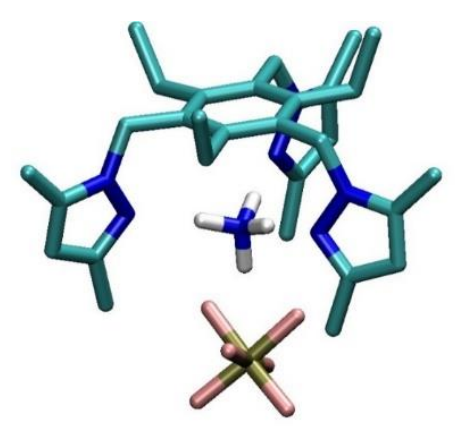

Figure 2.10. DFT calculated structure of $\left[1 \cdot \mathrm{NH}_{4}\right]^{+} \mathrm{PF}_{6}{ }^{-}$. 
The calculated free energy of $\left[\mathbf{2} \cdot \mathrm{NH}_{4}\right]^{+}+\mathrm{PF}_{6}^{-} \rightarrow\left[2 \cdot \mathrm{NH}_{4}\right]^{+} \mathrm{PF}_{6}^{-}$gas phase complexation is $-43.8 \mathrm{kcal} / \mathrm{mol}$. The optimized molecular structure of $\left[\mathbf{2} \cdot \mathrm{NH}_{4}\right]^{+} \mathrm{PF}_{6}{ }^{-}$has $\mathrm{C}_{3}$ symmetry with 3-fold axis running through the phenyl ring, $\mathrm{N}$ of the $\mathrm{NH}_{4}{ }^{+}$and $\mathrm{P}$ of $\mathrm{PF}_{6}$. The calculated free energy of $\left[2 \cdot \mathrm{NH}_{4}\right]^{+}$acetone $+\left[\mathrm{PF}_{6}\right]^{-}$acetone $\rightarrow\left[\left[2 \cdot \mathrm{NH}_{4}\right]^{+} \mathrm{PF}_{6}\right]_{\text {acetone }}$ complexation is $8.2 \mathrm{kcal} / \mathrm{mol}$.

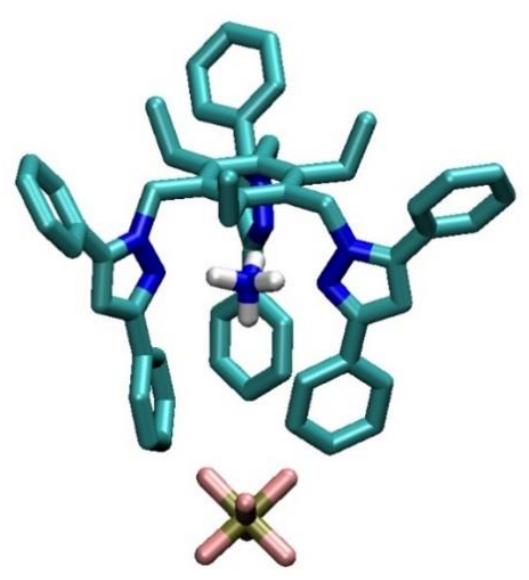

Figure 2.11. DFT calculated structure of $\left[2 \cdot \mathrm{NH}_{4}{ }^{+}\right] \mathrm{PF}_{6}{ }^{-}$.

\subsubsection{2. $\quad \mathrm{N}(\mathrm{pz}) \cdots \mathrm{N}\left(\mathrm{NH}_{4}\right), \mathrm{N}\left(\mathrm{NH}_{4}\right) \cdots \mathrm{C}($ phenyl $)$ and $\mathrm{N}\left(\mathrm{NH}_{4}\right) \cdots P$ distances.}

Table 2.1. Averaged distances (in $\AA$ ) and corresponding standard deviations.

\begin{tabular}{|llll|}
\hline & $\mathrm{N}(\mathrm{pz}) \cdots \mathrm{N}\left(\mathrm{NH}_{4}\right)$ & $\mathrm{N}\left(\mathrm{NH}_{4}\right) \cdots \mathrm{C}($ phenyl) & $\mathrm{N}\left(\mathrm{NH}_{4}\right) \cdots \mathrm{P}$ \\
\hline$\left[\mathbf{1} \cdot \mathrm{NH}_{4}\right]^{+}$ & $2.89(5)$ & $3.42(8)$ & - \\
\hline$\left[\mathbf{2} \cdot \mathrm{NH}_{4}\right]^{+}$ & $2.94(1)$ & $3.43(1)$ & - \\
\hline$\left[\mathbf{1} \cdot \mathrm{NH}_{4}\right]^{+} \mathrm{PF}_{6}^{-}$ & $3.00(3)$ & $3.50(6)$ & 3.66 \\
\hline$\left[\mathbf{1} \cdot \mathrm{NH}_{4}\right]^{+} \mathrm{PF}_{6}^{-} *$ & $3.00(5)$ & $3.43(7)$ & 4.16 \\
\hline$\left[\mathbf{2} \cdot \mathrm{NH}_{4}\right]^{+} \mathrm{PF}_{6}^{-}$ & $2.99(1)$ & $3.47(1)$ & 7.25 \\
\hline
\end{tabular}

*Crystal structure from J.Chin et al. 


\subsubsection{Cartesian coordinates of the optimized molecular structures.}

\section{Compound 1}

$\begin{array}{lrrr}78 & & & \\ & & & \\ \mathrm{~N} & -2.998802 & -1.556318 & 0.858378 \\ \mathrm{~N} & -3.556019 & -0.914080 & -0.198103 \\ \mathrm{C} & -4.851690 & -0.545188 & 0.043861 \\ \mathrm{C} & -5.126129 & -0.952864 & 1.337059 \\ \mathrm{C} & -3.942173 & -1.575959 & 1.799480 \\ \mathrm{C} & -2.815476 & -0.823108 & -1.459120 \\ \mathrm{C} & -1.357151 & -0.405554 & -1.310967 \\ \mathrm{C} & -0.346816 & -1.388873 & -1.294362 \\ \mathrm{C} & 1.002300 & -0.984043 & -1.246031 \\ \mathrm{C} & 1.337987 & 0.381160 & -1.164786 \\ \mathrm{C} & 0.317460 & 1.351037 & -1.154214 \\ \mathrm{C} & -1.035078 & 0.962827 & -1.220041 \\ \mathrm{C} & 0.681413 & 2.829464 & -1.097955 \\ \mathrm{~N} & 0.910402 & 3.341316 & 0.256263 \\ \mathrm{C} & 1.877141 & 4.214243 & 0.676243 \\ \mathrm{C} & 1.593530 & 4.482597 & 2.003674 \\ \mathrm{C} & 0.425506 & 3.740581 & 2.301853 \\ \mathrm{~N} & 0.013104 & 3.058917 & 1.233302 \\ \mathrm{C} & 2.797671 & 0.804804 & -1.090747 \\ \mathrm{C} & 3.444967 & 1.057484 & -2.466653 \\ \mathrm{C} & 2.110179 & -2.028398 & -1.311552 \\ \mathrm{~N} & 2.671317 & -2.400481 & -0.009974 \\ \mathrm{C} & 3.983473 & -2.628162 & 0.307295 \\ \mathrm{C} & 3.983711 & -3.076042 & 1.616246 \\ \mathrm{C} & 2.623979 & -3.105128 & 2.009353 \\ \mathrm{~N} & 1.834712 & -2.702613 & 1.013776 \\ \mathrm{C} & -0.710900 & -2.866747 & -1.299864 \\ \mathrm{C} & -0.828649 & -3.489971 & -2.702614 \\ \mathrm{C} & -2.139476 & 2.009487 & -1.179992 \\ \mathrm{C} & -2.536219 & 2.565442 & -2.560934 \\ \mathrm{C} & 2.970773 & 4.738182 & -0.201638 \\ \mathrm{C} & -0.327485 & 3.647517 & 3.594000 \\ \mathrm{C} & 5.119719 & -2.429214 & -0.647262\end{array}$




$\begin{array}{rrrr}\text { C } & 2.034287 & -3.505445 & 3.327394 \\ \text { C } & -5.726677 & 0.141035 & -0.958317 \\ \text { C } & -3.665497 & -2.198266 & 3.134113 \\ \text { H } & -2.883143 & -1.785140 & -1.972517 \\ \text { H } & -3.349981 & -0.107007 & -2.083619 \\ \text { H } & -0.099726 & 3.431260 & -1.568056 \\ \text { H } & 1.593974 & 3.021420 & -1.661868 \\ \text { H } & 2.940803 & -1.661369 & -1.915037 \\ \text { H } & 1.750432 & -2.933511 & -1.806031 \\ \text { H } & 2.161474 & 5.122554 & 2.664102 \\ \text { H } & 4.851780 & -3.339025 & 2.204151 \\ \text { H } & 6.063872 & -2.628014 & -0.135405 \\ \text { H } & 5.167093 & -1.406201 & -1.039162 \\ \text { H } & 5.059541 & -3.107255 & -1.507003 \\ \text { H } & 0.946605 & -3.416170 & 3.285604 \\ \text { H } & 2.400472 & -2.868737 & 4.140686 \\ \text { H } & 2.288577 & -4.540182 & 3.583643 \\ \text { H } & -1.193842 & 2.994503 & 3.468612 \\ \text { H } & -0.678674 & 4.630838 & 3.926949 \\ \text { H } & 0.298503 & 3.236942 & 4.394229 \\ \text { H } & 3.613054 & 5.405772 & 0.377159 \\ \text { H } & 2.581500 & 5.310259 & -1.052298 \\ \text { H } & 3.606401 & 3.941177 & -0.605496 \\ \text { H } & -1.832859 & 2.823695 & -0.519530 \\ \text { H } & -3.020708 & 1.584099 & -0.695125 \\ \text { H } & -3.339836 & 3.303715 & -2.465395 \\ \text { H } & -2.885560 & 1.776103 & -3.235762 \\ \text { H } & -1.693178 & 3.055122 & -3.059560 \\ \text { H } & -1.645407 & -2.996973 & -0.749972 \\ \text { H } & 0.026333 & -3.412882 & -0.707256 \\ \text { H } & 3.371454 & 0.048123 & -0.551403 \\ \text { H } & 2.887931 & 1.704239 & -0.477630 \\ \text { H } & 4.493123 & 1.356679 & -2.356576 \\ \text { H } & 2.926947 & 1.849292 & -3.018108 \\ \text { H } & 3.415944 & 0.163466 & -3.098143 \\ \text { H } & -1.107449 & -4.546763 & -2.633535 \\ \text { H } & 0.113591 & -3.429767 & -3.258998 \\ \text { H } & -1.585948 & -2.984240 & -3.311569 \\ \text { H } & -6.054979 & -0.811098 & 1.871404 \\ \text { H } & -2.650409 & -2.601000 & 3.148421 \\ \text { H } & -4.365929 & -3.012879 & 3.350888 \\ \text { H } & -3.756125 & -1.466227 & 3.944590 \\ & & & \end{array}$




$\begin{array}{lrrr}\mathrm{H} & -6.701751 & 0.343704 & -0.509995 \\ \mathrm{H} & -5.893708 & -0.472573 & -1.851598 \\ \mathrm{H} & -5.311276 & 1.099479 & -1.290420\end{array}$

Compound 2

120

$\begin{array}{lrrr}\mathrm{N} & 3.327104 & -1.124201 & -0.707982 \\ \mathrm{C} & 1.375160 & -0.419319 & -2.095126 \\ \mathrm{~N} & 2.960105 & -0.298814 & 0.291318 \\ \mathrm{C} & 1.059987 & 0.953223 & -2.101710 \\ \mathrm{C} & 2.164617 & 2.000239 & -2.071810 \\ \mathrm{H} & 1.818682 & 2.890116 & -1.542452 \\ \mathrm{H} & 2.994724 & 1.630500 & -1.466566 \\ \mathrm{C} & 2.665728 & 2.415330 & -3.467702 \\ \mathrm{H} & 3.444210 & 3.180915 & -3.386902 \\ \mathrm{H} & 1.857029 & 2.826206 & -4.081434 \\ \mathrm{H} & 3.083202 & 1.565978 & -4.019377 \\ \mathrm{C} & 2.832051 & -0.857165 & -2.067835 \\ \mathrm{H} & 2.976323 & -1.773281 & -2.638121 \\ \mathrm{H} & 3.469941 & -0.100457 & -2.529005 \\ \mathrm{C} & 4.097094 & -2.170416 & -0.260100 \\ \mathrm{C} & 3.490129 & -0.815073 & 1.407470 \\ \mathrm{C} & 4.213659 & -1.994182 & 1.110323 \\ \mathrm{H} & 4.753604 & -2.638512 & 1.787434 \\ \mathrm{C} & 4.646725 & -3.242084 & -1.108392 \\ \mathrm{C} & 5.338718 & -2.971709 & -2.301690 \\ \mathrm{H} & 5.487645 & -1.942999 & -2.615578 \\ \mathrm{C} & 5.865392 & -4.010342 & -3.068356 \\ \mathrm{H} & 6.399843 & -3.782922 & -3.986261 \\ \mathrm{C} & 5.721826 & -5.334689 & -2.652311 \\ \mathrm{H} & 6.134520 & -6.141898 & -3.250168 \\ \mathrm{C} & 5.049169 & -5.615304 & -1.461427 \\ \mathrm{H} & 4.933009 & -6.643122 & -1.130146 \\ \mathrm{C} & 4.514341 & -4.579850 & -0.697688 \\ \mathrm{H} & 3.974682 & -4.798199 & 0.218609 \\ \mathrm{C} & 3.256911 & -0.177134 & 2.714073 \\ \mathrm{C} & 2.231340 & 0.770954 & 2.871256 \\ \mathrm{H} & 1.617800 & 1.029640 & 2.014925 \\ \mathrm{C} & 1.993758 & 1.357322 & 4.111930\end{array}$




$\begin{array}{lrrr}\mathrm{H} & 1.186903 & 2.076144 & 4.217178 \\ \mathrm{C} & 2.775642 & 1.011107 & 5.216841 \\ \mathrm{H} & 2.586083 & 1.466522 & 6.184597 \\ \mathrm{C} & 3.799527 & 0.073886 & 5.070691 \\ \mathrm{H} & 4.416259 & -0.198209 & 5.922849 \\ \mathrm{C} & 4.039049 & -0.515183 & 3.829823 \\ \mathrm{H} & 4.847149 & -1.233003 & 3.723217 \\ \mathrm{~N} & -2.629445 & -2.301647 & -0.790715 \\ \mathrm{C} & -0.988965 & -0.979732 & -2.129403 \\ \mathrm{~N} & -1.766321 & -2.422566 & 0.236208 \\ \mathrm{C} & 0.356994 & -1.392621 & -2.092854 \\ \mathrm{C} & 0.713235 & -2.871281 & -2.042086 \\ \mathrm{H} & 1.634820 & -3.008314 & -1.472829 \\ \mathrm{H} & -0.042283 & -3.405733 & -1.462962 \\ \mathrm{C} & 0.877830 & -3.519127 & -3.429235 \\ \mathrm{H} & 1.161872 & -4.572090 & -3.334030 \\ \mathrm{H} & 1.650995 & -3.016574 & -4.019852 \\ \mathrm{H} & -0.048429 & -3.470671 & -4.012490 \\ \mathrm{C} & -2.098953 & -2.020847 & -2.133986 \\ \mathrm{H} & -2.941956 & -1.689668 & -2.738215 \\ \mathrm{H} & -1.750271 & -2.958085 & -2.572782 \\ \mathrm{C} & -3.937545 & -2.404713 & -0.383610 \\ \mathrm{C} & -2.518998 & -2.602051 & 1.329201 \\ \mathrm{C} & -3.892529 & -2.595136 & 0.989114 \\ \mathrm{H} & -4.746149 & -2.712803 & 1.639145 \\ \mathrm{C} & -5.110867 & -2.317869 & -1.270455 \\ \mathrm{C} & -5.208883 & -3.066325 & -2.456328 \\ \mathrm{H} & -4.403375 & -3.738245 & -2.737228 \\ \mathrm{C} & -6.345496 & -2.980062 & -3.259433 \\ \mathrm{H} & -6.404933 & -3.568080 & -4.170831 \\ \mathrm{C} & -7.408223 & -2.155364 & -2.888145 \\ \mathrm{H} & -8.293624 & -2.091373 & -3.513798 \\ \mathrm{C} & -7.328496 & -1.416859 & -1.706140 \\ \mathrm{H} & -8.151170 & -0.772745 & -1.409381 \\ \mathrm{C} & -6.190496 & -1.494915 & -0.905671 \\ \mathrm{H} & -6.122272 & -0.907825 & 0.005102 \\ \mathrm{C} & -1.892043 & -2.750012 & 2.653376 \\ \mathrm{C} & -0.553442 & -2.370886 & 2.852272 \\ \mathrm{H} & 0.008406 & -1.967373 & 2.016986 \\ \mathrm{C} & 0.040555 & -2.499080 & 4.105292 \\ \mathrm{H} & 1.072092 & -2.188702 & 4.241572 \\ \mathrm{C} & -0.689024 & -3.008514 & 5.182419\end{array}$




\begin{tabular}{|c|c|c|c|}
\hline & 586 & $H 1$ & \\
\hline & -2.019044 & -3.388777 & 711 \\
\hline & -2.593733 & -3.789870 & 054 \\
\hline & -2.616201 & -3.261212 & 2040 \\
\hline & -3.646682 & -3.575797 & \\
\hline & -0.6 & & \\
\hline & -0.29 & 81 & \\
\hline & -1.2 & 439 & \\
\hline & -1.322555 & 0.388695 & \\
\hline & -2.7 & & \\
\hline & -3.3 & 44 & \\
\hline & -2.892272 & & \\
\hline & -3.3 & 890 & \\
\hline & -4.4 & & \\
\hline & -3.2 & & \\
\hline & -2.8 & 66 & -4 \\
\hline & -0.6 & & \\
\hline & 0.0 & & \\
\hline & -1.6 & & 264 \\
\hline & -0.1 & 4.5 & -0 . \\
\hline & -1.0 & & \\
\hline & -0.3 & & \\
\hline & -0.0 & 5. & \\
\hline & 0.5 & 5.5 & -1 . \\
\hline & 0.0 & 6.0 & -2 \\
\hline & -0.9 & & \\
\hline & 0.7 & 6.9 & -3 . \\
\hline & 0.3 & 7.3 & -4 \\
\hline & 1.9 & & -2 \\
\hline & 2.4 & 8.2 & -3 . \\
\hline & 2.4 & 7.0 & -1. \\
\hline & 3.4 & 7.4 & -1 \\
\hline & & & -0 . \\
\hline & 2.2 & 5.7 & \\
\hline & -1.5 & 2.9 & 62 \\
\hline & -1.9 & & \\
\hline & -1.8 & 0.9 & \\
\hline & -2.3 & 1.1 & \\
\hline & -2.5 & 849 & 4277 \\
\hline & -2.451277 & 2.029712 & \\
\hline & -2.789652 & 1.667011 & 6.091992 \\
\hline & -2.111768 & 3.373439 & 4.959668 \\
\hline
\end{tabular}




$\begin{array}{llll}\mathrm{H} & -2.192865 & 4.064179 & 5.794444 \\ \mathrm{C} & -1.670348 & 3.837145 & 3.721045 \\ \mathrm{H} & -1.421425 & 4.887228 & 3.598799\end{array}$

$\left[\mathbf{1} \cdot \mathrm{NH}_{4}{ }^{+}\right]$

83

$\begin{array}{lrrr}\mathrm{N} & -2.864931 & -1.124299 & 0.932088 \\ \mathrm{~N} & -3.517089 & -0.654233 & -0.170350 \\ \mathrm{C} & -4.845786 & -0.458005 & 0.078207 \\ \mathrm{C} & -5.048436 & -0.790784 & 1.407404 \\ \mathrm{C} & -3.791025 & -1.204015 & 1.896006 \\ \mathrm{C} & -2.872849 & -0.708434 & -1.490665 \\ \mathrm{C} & -1.398961 & -0.341764 & -1.467584 \\ \mathrm{C} & -0.420158 & -1.358776 & -1.456096 \\ \mathrm{C} & 0.942154 & -0.992527 & -1.454157 \\ \mathrm{C} & 1.325721 & 0.361480 & -1.415030 \\ \mathrm{C} & 0.333253 & 1.358774 & -1.364346 \\ \mathrm{C} & -1.033078 & 1.019683 & -1.411747 \\ \mathrm{C} & 0.758184 & 2.801486 & -1.175644 \\ \mathrm{~N} & 1.090337 & 3.094657 & 0.228758 \\ \mathrm{C} & 1.947152 & 4.058964 & 0.681364 \\ \mathrm{C} & 1.737866 & 4.154024 & 2.047658 \\ \mathrm{C} & 0.718257 & 3.223691 & 2.347184 \\ \mathrm{~N} & 0.325077 & 2.581498 & 1.238834 \\ \mathrm{C} & 2.799193 & 0.742126 & -1.445085 \\ \mathrm{C} & 3.333188 & 0.936647 & -2.878447 \\ \mathrm{C} & 2.025383 & -2.054209 & -1.423930 \\ \mathrm{~N} & 2.578672 & -2.260657 & -0.077275 \\ \mathrm{C} & 3.818982 & -2.739634 & 0.234991 \\ \mathrm{C} & 3.788349 & -3.043251 & 1.586135 \\ \mathrm{C} & 2.482767 & -2.734969 & 2.022724 \\ \mathrm{~N} & 1.750252 & -2.264115 & 1.005946 \\ \mathrm{C} & -0.823577 & -2.827198 & -1.419479 \\ \mathrm{C} & -0.988350 & -3.472081 & -2.807722 \\ \mathrm{C} & -2.105870 & 2.099503 & -1.419880 \\ \mathrm{C} & -2.443446 & 2.595363 & -2.840212 \\ \mathrm{C} & 2.901815 & 4.802866 & -0.205006 \\ \mathrm{C} & 0.102698 & 2.928253 & 3.686664\end{array}$




$\begin{array}{cccc}\text { C } & 4.923445 & -2.872713 & -0.766781 \\ \mathrm{C} & 1.907792 & -2.877748 & 3.402795 \\ \mathrm{C} & -5.810127 & 0.032361 & -0.955806 \\ \mathrm{C} & -3.431643 & -1.668617 & 3.276369 \\ \mathrm{H} & -3.019172 & -1.708668 & -1.900084 \\ \mathrm{H} & -3.419756 & -0.024033 & -2.138357 \\ \mathrm{H} & -0.018615 & 3.493655 & -1.505254 \\ \mathrm{H} & 1.646870 & 3.024331 & -1.766300 \\ \mathrm{H} & 2.854030 & -1.764074 & -2.068837 \\ \mathrm{H} & 1.659694 & -3.010795 & -1.800107 \\ \mathrm{H} & 2.261958 & 4.809707 & 2.731049 \\ \mathrm{H} & 4.603425 & -3.439132 & 2.175051 \\ \mathrm{H} & 5.840522 & -3.179680 & -0.261457 \\ \mathrm{H} & 5.131400 & -1.928921 & -1.284454 \\ \mathrm{H} & 4.695229 & -3.624546 & -1.529765 \\ \mathrm{H} & 0.828905 & -2.694326 & 3.400020 \\ \mathrm{H} & 2.377969 & -2.185141 & 4.111418 \\ \mathrm{H} & 2.064984 & -3.891757 & 3.787235 \\ \mathrm{H} & -0.772735 & 2.279206 & 3.585625 \\ \mathrm{H} & -0.226954 & 3.853752 & 4.172729 \\ \mathrm{H} & 0.816837 & 2.446014 & 4.366004 \\ \mathrm{H} & 3.547520 & 5.436725 & 0.407551 \\ \mathrm{H} & 2.385067 & 5.450277 & -0.923604 \\ \mathrm{H} & 3.550467 & 4.127397 & -0.777343 \\ \mathrm{H} & -1.795949 & 2.943122 & -0.799153 \\ \mathrm{H} & -3.011687 & 1.726421 & -0.938728 \\ \mathrm{H} & -3.232362 & 3.353291 & -2.811975 \\ \mathrm{H} & -2.786987 & 1.777056 & -3.482077 \\ \mathrm{H} & -1.568380 & 3.037130 & -3.327975 \\ \mathrm{H} & -1.750197 & -2.933359 & -0.850703 \\ \mathrm{H} & -0.089078 & -3.392510 & -0.841219 \\ \mathrm{H} & 3.391151 & -0.019682 & -0.934574 \\ \mathrm{H} & 2.969193 & 1.651952 & -0.866210 \\ \mathrm{H} & 4.395107 & 1.199261 & -2.863164 \\ \mathrm{H} & 2.796041 & 1.731383 & -3.406462 \\ \mathrm{H} & 3.219013 & 0.026504 & -3.475591 \\ \mathrm{H} & -1.284937 & -4.520732 & -2.709520 \\ \mathrm{H} & -0.057055 & -3.438726 & -3.383117 \\ \mathrm{H} & -1.752154 & -2.959610 & -3.401130 \\ \mathrm{H} & -5.983618 & -0.738036 & 1.947986 \\ \mathrm{H} & -2.403682 & -2.041574 & 3.305243 \\ \mathrm{H} & -4.089002 & -2.484016 & 3.596940\end{array}$




$\begin{array}{rrrr}\text { H } & -3.529022 & -0.863874 & 4.014385 \\ \mathrm{H} & -6.787138 & 0.189169 & -0.496203 \\ \mathrm{H} & -5.938423 & -0.681796 & -1.776291 \\ \mathrm{H} & -5.491535 & 0.984624 & -1.394757 \\ \mathrm{~N} & -0.230851 & -0.310782 & 1.670693 \\ \mathrm{H} & 0.480949 & -0.987435 & 1.284769 \\ \mathrm{H} & -0.037454 & 0.674173 & 1.385938 \\ \mathrm{H} & -0.200582 & -0.352387 & 2.687685 \\ \mathrm{H} & -1.187469 & -0.607798 & 1.334615\end{array}$

$\left[\mathbf{1} \cdot \mathrm{NH}_{4}{ }^{+}\right] \mathrm{PF}_{6}{ }^{-}$

90

$\begin{array}{rrrr}\mathrm{N} & 0.018118 & -2.001018 & -2.095262 \\ \mathrm{~N} & 1.241092 & -2.547261 & -2.362374 \\ \mathrm{C} & 1.129924 & -3.797098 & -2.903380 \\ \mathrm{C} & -0.222814 & -4.074011 & -2.957783 \\ \mathrm{C} & -0.877806 & -2.932178 & -2.443843 \\ \mathrm{C} & 2.458110 & -1.731480 & -2.317839 \\ \mathrm{C} & 2.422853 & -0.632991 & -1.269454 \\ \mathrm{C} & 2.150335 & 0.696758 & -1.651651 \\ \mathrm{C} & 2.170221 & 1.708571 & -0.669403 \\ \mathrm{C} & 2.373887 & 1.394310 & 0.689037 \\ \mathrm{C} & 2.614624 & 0.056283 & 1.055052 \\ \mathrm{C} & 2.658032 & -0.958644 & 0.079602 \\ \mathrm{C} & 1.968031 & 3.158652 & -1.074762 \\ \mathrm{~N} & 0.610661 & 3.664356 & -0.850315 \\ \mathrm{~N} & -0.474752 & 2.845560 & -0.972238 \\ \mathrm{C} & -1.542619 & 3.651222 & -0.925416 \\ \mathrm{C} & -1.135526 & 4.996990 & -0.793136 \\ \mathrm{C} & 0.246408 & 4.977578 & -0.756465 \\ \mathrm{C} & 1.230128 & 6.099411 & -0.647064 \\ \mathrm{C} & -2.937167 & 3.110929 & -0.978026 \\ \mathrm{C} & 1.790417 & 1.027622 & -3.093751 \\ \mathrm{C} & 2.996221 & 1.369419 & -3.989266 \\ \mathrm{C} & 2.957609 & -2.395340 & 0.482333 \\ \mathrm{C} & 4.464014 & -2.720851 & 0.482594 \\ \mathrm{C} & 2.801125 & -0.309253 & 2.516600 \\ \mathrm{~N} & 1.591944 & -0.874823 & 3.123401\end{array}$




$\begin{array}{rrrr}\mathrm{C} & 1.538083 & -1.638158 & 4.255434 \\ \mathrm{C} & 0.201798 & -1.724864 & 4.597487 \\ \mathrm{C} & -0.499511 & -0.970923 & 3.630428 \\ \mathrm{~N} & 0.352312 & -0.444822 & 2.742323 \\ \mathrm{C} & 2.313220 & 2.490508 & 1.743208 \\ \mathrm{C} & 3.689535 & 3.083665 & 2.101284 \\ \mathrm{C} & 2.750408 & -2.209557 & 4.920004 \\ \mathrm{C} & -1.978290 & -0.767356 & 3.517176 \\ \mathrm{C} & 2.308149 & -4.613829 & -3.331792 \\ \mathrm{C} & -2.346627 & -2.721355 & -2.250784 \\ \mathrm{~N} & -0.775283 & 0.037375 & -0.034248 \\ \mathrm{H} & 2.230657 & 3.296843 & -2.126342 \\ \mathrm{H} & 2.641534 & 3.802249 & -0.505034 \\ \mathrm{H} & 3.116497 & 0.559654 & 3.098648 \\ \mathrm{H} & 3.591667 & -1.053478 & 2.627989 \\ \mathrm{H} & 3.288121 & -2.412547 & -2.121387 \\ \mathrm{H} & 2.638586 & -1.308692 & -3.308779 \\ \mathrm{H} & -0.218031 & -2.271190 & 5.429444 \\ \mathrm{H} & -0.680724 & -4.986195 & -3.311723 \\ \mathrm{H} & 1.966515 & -5.588248 & -3.686114 \\ \mathrm{H} & 3.011055 & -4.788095 & -2.508672 \\ \mathrm{H} & 2.866321 & -4.139740 & -4.147859 \\ \mathrm{H} & -2.621494 & -1.672620 & -2.364074 \\ \mathrm{H} & -2.669683 & -3.016414 & -1.248757 \\ \mathrm{H} & -2.912064 & -3.312884 & -2.975720 \\ \mathrm{H} & -2.220519 & 0.233306 & 3.155093 \\ \mathrm{H} & -2.454626 & -0.910818 & 4.490461 \\ \mathrm{H} & -2.431978 & -1.467167 & 2.810383 \\ \mathrm{H} & 2.444064 & -2.841344 & 5.755863 \\ \mathrm{H} & 3.412586 & -1.431232 & 5.318039 \\ \mathrm{H} & 3.343766 & -2.828299 & 4.236690 \\ \mathrm{H} & 1.829237 & 2.103967 & 2.643955 \\ \mathrm{H} & 1.654008 & 3.290871 & 1.401303 \\ \mathrm{H} & 3.587761 & 3.874593 & 2.851142 \\ \mathrm{H} & 4.182673 & 3.513560 & 1.222812 \\ \mathrm{H} & 4.366556 & 2.323635 & 2.505051 \\ \mathrm{H} & 1.079103 & 1.856942 & -3.102260 \\ \mathrm{H} & 1.235063 & 0.190894 & -3.525195 \\ \mathrm{H} & 2.435858 & -3.085362 & -0.184407 \\ \mathrm{H} & 2.539591 & -2.596006 & 1.471565 \\ \mathrm{H} & 4.636270 & -3.761003 & 0.776681 \\ \mathrm{H} & 5.016329 & -2.078872 & 1.176551\end{array}$




\begin{tabular}{|c|c|c|c|}
\hline $\mathrm{H}$ & 4.909568 & -2.573200 & 673 \\
\hline & 2.664747 & 1.629814 & -4.999263 \\
\hline & 3.693526 & 0.528801 & -4.072376 \\
\hline & 3.565246 & 2.216521 & -3.592578 \\
\hline & -1.771018 & 5.867822 & -0.722242 \\
\hline & -3.018411 & 2.275680 & $-1 .($ \\
\hline & -3.633685 & 3.894340 & 7241 \\
\hline & -3.261241 & 2.729555 & -0. \\
\hline & 0.693381 & 7.047653 & -0.578125 \\
\hline & 1.895493 & 6.156864 & 5706 \\
\hline & 1.861454 & 6.012014 & 421 \\
\hline & -0.417804 & -0.642300 & -0.735822 \\
\hline & -0.307884 & -0.100741 & 0.882835 \\
\hline 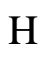 & -1.782454 & -0.121453 & 0.078959 \\
\hline $\mathrm{H}$ & -0.617457 & 1.007604 & -0.378184 \\
\hline & -4.386511 & -0.467206 & 0.265348 \\
\hline & -3.513181 & 0.018986 & -1.068650 \\
\hline$F$ & -5.141760 & -0.948039 & 1.608197 \\
\hline 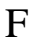 & -3.129488 & -1.517220 & 0.599354 \\
\hline & -5.097357 & -1.613408 & -0.625283 \\
\hline & -5.532288 & 0.613023 & -0.080372 \\
\hline & -3.551009 & 0.678109 & 1.130027 \\
\hline
\end{tabular}

\section{$\left[\mathbf{2} \cdot \mathrm{NH}_{4}{ }^{+}\right]$}

125

$\begin{array}{lrrr}\mathrm{N} & -2.248914 & -2.676503 & -0.770972 \\ \mathrm{C} & -0.823192 & -1.100697 & -2.082077 \\ \mathrm{~N} & -1.531686 & -2.420609 & 0.352230 \\ \mathrm{C} & 0.576216 & -1.262621 & -2.070597 \\ \mathrm{C} & 1.202993 & -2.650737 & -2.064983 \\ \mathrm{H} & 2.161675 & -2.622159 & -1.542368 \\ \mathrm{H} & 0.585270 & -3.330384 & -1.471698 \\ \mathrm{C} & 1.418885 & -3.237649 & -3.473406 \\ \mathrm{H} & 1.878985 & -4.228126 & -3.409267 \\ \mathrm{H} & 2.074348 & -2.602832 & -4.078248 \\ \mathrm{H} & 0.476469 & -3.338020 & -4.021269 \\ \mathrm{C} & -1.719758 & -2.324120 & -2.099350 \\ \mathrm{H} & -2.583896 & -2.170961 & -2.745799 \\ \mathrm{H} & -1.185198 & -3.184825 & -2.502636\end{array}$




$\begin{array}{lrrr}\mathrm{C} & -3.425974 & -3.318692 & -0.489690 \\ \mathrm{C} & -2.265812 & -2.904115 & 1.371095 \\ \mathrm{C} & -3.465561 & -3.464926 & 0.889428 \\ \mathrm{H} & -4.236690 & -3.967890 & 1.452453 \\ \mathrm{C} & -4.416128 & -3.737576 & -1.498887 \\ \mathrm{C} & -4.054794 & -4.487488 & -2.630610 \\ \mathrm{H} & -3.019811 & -4.780476 & -2.777624 \\ \mathrm{C} & -5.022587 & -4.892380 & -3.548334 \\ \mathrm{H} & -4.730640 & -5.477322 & -4.415116 \\ \mathrm{C} & -6.363552 & -4.561770 & -3.346434 \\ \mathrm{H} & -7.115762 & -4.880286 & -4.061422 \\ \mathrm{C} & -6.735013 & -3.827044 & -2.219040 \\ \mathrm{H} & -7.776896 & -3.569726 & -2.055049 \\ \mathrm{C} & -5.769806 & -3.417647 & -1.301221 \\ \mathrm{H} & -6.057228 & -2.838178 & -0.429154 \\ \mathrm{C} & -1.788832 & -2.823015 & 2.761384 \\ \mathrm{C} & -0.415357 & -2.749838 & 3.049688 \\ \mathrm{H} & 0.299733 & -2.789887 & 2.233451 \\ \mathrm{C} & 0.031457 & -2.668714 & 4.367629 \\ \mathrm{H} & 1.095721 & -2.603143 & 4.569960 \\ \mathrm{C} & -0.885296 & -2.683134 & 5.420999 \\ \mathrm{H} & -0.536823 & -2.631684 & 6.447856 \\ \mathrm{C} & -2.251368 & -2.775491 & 5.147186 \\ \mathrm{H} & -2.969922 & -2.795862 & 5.961190 \\ \mathrm{C} & -2.701163 & -2.837536 & 3.828742 \\ \mathrm{H} & -3.766431 & -2.889096 & 3.624887 \\ \mathrm{~N} & -1.214906 & 3.296441 & -0.661226 \\ \mathrm{C} & -0.564971 & 1.316334 & -2.041157 \\ \mathrm{~N} & -1.326997 & 2.514745 & 0.442464 \\ \mathrm{C} & -1.403446 & 0.184649 & -2.062924 \\ \mathrm{C} & -2.918494 & 0.336968 & -2.070166 \\ \mathrm{H} & -3.383538 & -0.515286 & -1.570805 \\ \mathrm{H} & -3.208275 & 1.201083 & -1.466566 \\ \mathrm{C} & -3.507161 & 0.472465 & -3.488172 \\ \mathrm{H} & -4.595550 & 0.574403 & -3.446893 \\ \mathrm{H} & -3.274114 & -0.402594 & -4.102994 \\ \mathrm{H} & -3.103919 & 1.345659 & -4.010884 \\ \mathrm{C} & -1.174877 & 2.705474 & -2.010184 \\ \mathrm{H} & -0.607423 & 3.398036 & -2.631943 \\ \mathrm{H} & -2.187468 & 2.688310 & -2.414098 \\ \mathrm{C} & -1.199562 & 4.628394 & -0.342505 \\ \mathrm{C} & -1.380533 & 3.362857 & 1.485965\end{array}$




$\begin{array}{rrrr}\text { C } & -1.291992 & 4.696681 & 1.039876 \\ \mathrm{H} & -1.347275 & 5.599389 & 1.628884 \\ \mathrm{C} & -1.089568 & 5.723776 & -1.324810 \\ \mathrm{C} & -1.965605 & 5.834308 & -2.417539 \\ \mathrm{H} & -2.758623 & 5.105094 & -2.553723 \\ \mathrm{C} & -1.850696 & 6.898409 & -3.310534 \\ \mathrm{H} & -2.538251 & 6.975085 & -4.147269 \\ \mathrm{C} & -0.866540 & 7.869923 & -3.121728 \\ \mathrm{H} & -0.780177 & 8.699019 & -3.817215 \\ \mathrm{C} & 0.000303 & 7.777136 & -2.031561 \\ \mathrm{H} & 0.764246 & 8.532876 & -1.877060 \\ \mathrm{C} & -0.109207 & 6.712575 & -1.138714 \\ \mathrm{H} & 0.570438 & 6.635113 & -0.295412 \\ \mathrm{C} & -1.520966 & 2.864825 & 2.863925 \\ \mathrm{C} & -2.134676 & 1.627233 & 3.122637 \\ \mathrm{H} & -2.544014 & 1.055952 & 2.294731 \\ \mathrm{C} & -2.255243 & 1.152166 & 4.427595 \\ \mathrm{H} & -2.724075 & 0.189869 & 4.607476 \\ \mathrm{C} & -1.785552 & 1.916153 & 5.497891 \\ \mathrm{H} & -1.889617 & 1.551637 & 6.515177 \\ \mathrm{C} & -1.192356 & 3.156596 & 5.254230 \\ \mathrm{H} & -0.832665 & 3.760591 & 6.081994 \\ \mathrm{C} & -1.053835 & 3.624939 & 3.948079 \\ \mathrm{H} & -0.573578 & 4.581734 & 3.765963 \\ \mathrm{~N} & 3.467417 & -0.571398 & -0.727168 \\ \mathrm{C} & 1.398348 & -0.116935 & -2.057956 \\ \mathrm{~N} & 2.860125 & -0.122608 & 0.400674 \\ \mathrm{C} & 0.838363 & 1.175243 & -2.032222 \\ \mathrm{C} & 1.728589 & 2.409980 & -1.994340 \\ \mathrm{H} & 1.223053 & 3.215418 & -1.457639 \\ \mathrm{H} & 2.622844 & 2.202192 & -1.400910 \\ \mathrm{C} & 2.135740 & 2.917109 & -3.391625 \\ \mathrm{H} & 2.768658 & 3.805472 & -3.308250 \\ \mathrm{H} & 1.260890 & 3.183082 & -3.993170 \\ \mathrm{H} & 2.690057 & 2.158689 & -3.953518 \\ \mathrm{C} & 2.906553 & -0.280358 & -2.058578 \\ \mathrm{H} & 3.212671 & -1.101848 & -2.706349 \\ \mathrm{H} & 3.386700 & 0.615903 & -2.452261 \\ \mathrm{C} & 4.617836 & -1.259935 & -0.445708 \\ \mathrm{C} & 3.634241 & -0.534011 & 1.421017 \\ \mathrm{C} & 4.740316 & -1.260107 & 0.936182 \\ \mathrm{H} & 5.558623 & -1.680416 & 1.500382\end{array}$




$\begin{array}{lrrr}\mathrm{C} & 5.504030 & -1.865147 & -1.457597 \\ \mathrm{C} & 5.992079 & -1.133714 & -2.553456 \\ \mathrm{H} & 5.725830 & -0.087649 & -2.670262 \\ \mathrm{C} & 6.852555 & -1.729481 & -3.473956 \\ \mathrm{H} & 7.227582 & -1.150364 & -4.312229 \\ \mathrm{C} & 7.245007 & -3.058773 & -3.310104 \\ \mathrm{H} & 7.917795 & -3.519635 & -4.026686 \\ \mathrm{C} & 6.775926 & -3.790849 & -2.217956 \\ \mathrm{H} & 7.080616 & -4.824073 & -2.083099 \\ \mathrm{C} & 5.911580 & -3.200063 & -1.298176 \\ \mathrm{H} & 5.537150 & -3.773080 & -0.455333 \\ \mathrm{C} & 3.290969 & -0.213953 & 2.816271 \\ \mathrm{C} & 2.544049 & 0.933778 & 3.132562 \\ \mathrm{H} & 2.257570 & 1.615505 & 2.337367 \\ \mathrm{C} & 2.210872 & 1.223482 & 4.454865 \\ \mathrm{H} & 1.625086 & 2.109351 & 4.679345 \\ \mathrm{C} & 2.641115 & 0.385860 & 5.485960 \\ \mathrm{H} & 2.391840 & 0.617846 & 6.516763 \\ \mathrm{C} & 3.404570 & -0.744163 & 5.185832 \\ \mathrm{H} & 3.751896 & -1.394462 & 5.983232 \\ \mathrm{C} & 3.719988 & -1.047524 & 3.861967 \\ \mathrm{H} & 4.294732 & -1.940316 & 3.635004 \\ \mathrm{~N} & 0.011983 & -0.013657 & 1.072070 \\ \mathrm{H} & 0.016255 & -0.032131 & 2.093758 \\ \mathrm{H} & 1.004114 & -0.003700 & 0.734074 \\ \mathrm{H} & -0.481385 & -0.868088 & 0.722624 \\ \mathrm{H} & -0.489396 & 0.849635 & 0.752877\end{array}$

$\left[\mathbf{2} \cdot \mathrm{NH}_{4}{ }^{+}\right] \mathrm{PF}_{6}^{-}$

132

$\begin{array}{llll}\mathrm{N} & -1.774303 & 3.553518 & 0.149159 \\ \mathrm{C} & -3.036515 & 1.389675 & 0.199833 \\ \mathrm{~N} & -0.595058 & 2.886819 & 0.281244 \\ \mathrm{C} & -3.032470 & 0.528045 & 1.312644 \\ \mathrm{C} & -3.026494 & 1.082567 & 2.731081 \\ \mathrm{H} & -2.530219 & 0.379599 & 3.401463 \\ \mathrm{H} & -2.409949 & 1.984865 & 2.771381 \\ \mathrm{C} & -4.433697 & 1.387625 & 3.280581 \\ \mathrm{H} & -4.372830 & 1.764346 & 4.306097\end{array}$




$\begin{array}{crcc}\mathrm{H} & -5.062599 & 0.491660 & 3.289922 \\ \mathrm{H} & -4.954227 & 2.137191 & 2.675664 \\ \mathrm{C} & -3.060287 & 2.892336 & 0.411304 \\ \mathrm{H} & -3.789717 & 3.361442 & -0.251558 \\ \mathrm{H} & -3.376636 & 3.127077 & 1.427308 \\ \mathrm{C} & -1.585307 & 4.841397 & -0.281037 \\ \mathrm{C} & 0.360978 & 3.766025 & -0.068308 \\ \mathrm{C} & -0.218087 & 4.999362 & -0.436093 \\ \mathrm{H} & 0.293944 & 5.906717 & -0.716724 \\ \mathrm{C} & -2.661841 & 5.820210 & -0.519197 \\ \mathrm{C} & -3.683224 & 6.057554 & 0.416153 \\ \mathrm{H} & -3.693484 & 5.512227 & 1.354597 \\ \mathrm{C} & -4.663157 & 7.017793 & 0.168617 \\ \mathrm{H} & -5.441754 & 7.192778 & 0.905057 \\ \mathrm{C} & -4.634956 & 7.763092 & -1.011009 \\ \mathrm{H} & -5.397209 & 8.512604 & -1.200702 \\ \mathrm{C} & -3.617888 & 7.545064 & -1.942241 \\ \mathrm{H} & -3.587114 & 8.122997 & -2.860973 \\ \mathrm{C} & -2.640714 & 6.581792 & -1.700278 \\ \mathrm{H} & -1.856427 & 6.404804 & -2.429652 \\ \mathrm{C} & 1.791973 & 3.424327 & -0.057099 \\ \mathrm{C} & 2.332117 & 2.531202 & 0.885152 \\ \mathrm{H} & 1.686887 & 2.108664 & 1.651162 \\ \mathrm{C} & 3.691837 & 2.223266 & 0.867976 \\ \mathrm{H} & 4.111354 & 1.524558 & 1.582463 \\ \mathrm{C} & 4.538669 & 2.812942 & -0.075657 \\ \mathrm{H} & 5.586282 & 2.542276 & -0.088689 \\ \mathrm{C} & 4.010885 & 3.712702 & -1.003058 \\ \mathrm{H} & 4.661062 & 4.170741 & -1.742656 \\ \mathrm{C} & 2.650054 & 4.014092 & -0.999055 \\ \mathrm{H} & 2.242688 & 4.694412 & -1.741743 \\ \mathrm{~N} & -1.773549 & -1.646938 & -3.151921 \\ \mathrm{C} & -3.036310 & -0.520510 & -1.304139 \\ \mathrm{~N} & -0.594355 & -1.199274 & -2.640409 \\ \mathrm{C} & -3.031788 & 0.874037 & -1.114331 \\ \mathrm{C} & -3.025370 & 1.825257 & -2.303724 \\ \mathrm{H} & -2.529468 & 2.757413 & -2.029838 \\ \mathrm{H} & -2.408323 & 1.409142 & -3.104971 \\ \mathrm{C} & -4.432355 & 2.148308 & -2.843370 \\ \mathrm{H} & -4.371225 & 2.848168 & -3.682280 \\ \mathrm{H} & -5.061771 & 2.604117 & -2.072385 \\ \mathrm{H} & -4.952482 & 1.249552 & -3.190395 \\ & & & \end{array}$




$\begin{array}{lrrr}\mathrm{C} & -3.059491 & -1.088587 & -2.711305 \\ \mathrm{H} & -3.789338 & -1.896757 & -2.786889 \\ \mathrm{H} & -3.374796 & -0.325780 & -3.422738 \\ \mathrm{C} & -1.584580 & -2.664174 & -4.051326 \\ \mathrm{C} & 0.361669 & -1.942180 & -3.226384 \\ \mathrm{C} & -0.217428 & -2.877837 & -4.110081 \\ \mathrm{H} & 0.294550 & -3.575225 & -4.754871 \\ \mathrm{C} & -2.661203 & -3.360050 & -4.779614 \\ \mathrm{C} & -3.681542 & -2.668795 & -5.454558 \\ \mathrm{H} & -3.690787 & -1.583398 & -5.453287 \\ \mathrm{C} & -4.661723 & -3.363525 & -6.161794 \\ \mathrm{H} & -5.439520 & -2.813373 & -6.682889 \\ \mathrm{C} & -4.634797 & -4.757880 & -6.215135 \\ \mathrm{H} & -5.397246 & -5.297097 & -6.768939 \\ \mathrm{C} & -3.618733 & -5.455232 & -5.559043 \\ \mathrm{H} & -3.588955 & -6.539937 & -5.598421 \\ \mathrm{C} & -2.641298 & -4.763800 & -4.846391 \\ \mathrm{H} & -1.857803 & -5.306828 & -4.327087 \\ \mathrm{C} & 1.792677 & -1.761975 & -2.935900 \\ \mathrm{C} & 2.333164 & -0.499629 & -2.633154 \\ \mathrm{H} & 1.688183 & 0.375219 & -2.650111 \\ \mathrm{C} & 3.692874 & -0.361088 & -2.357521 \\ \mathrm{H} & 4.112759 & 0.606744 & -2.109214 \\ \mathrm{C} & 4.539350 & -1.473396 & -2.396470 \\ \mathrm{H} & 5.586885 & -1.349708 & -2.155028 \\ \mathrm{C} & 4.011268 & -2.726152 & -2.712551 \\ \mathrm{H} & 4.661168 & -3.595889 & -2.739510 \\ \mathrm{C} & 2.650442 & -2.872858 & -2.975874 \\ \mathrm{H} & 2.242837 & -3.856015 & -3.194085 \\ \mathrm{~N} & -1.775332 & -1.906219 & 3.001416 \\ \mathrm{C} & -3.037107 & -0.867882 & 1.102129 \\ \mathrm{~N} & -0.596031 & -1.687244 & 2.358104 \\ \mathrm{C} & -3.032610 & -1.400799 & -0.200475 \\ \mathrm{C} & -3.027241 & -2.906445 & -0.429470 \\ \mathrm{H} & -2.531046 & -3.135721 & -1.373414 \\ \mathrm{H} & -2.410951 & -3.392860 & 0.331767 \\ \mathrm{C} & -4.434758 & -3.534089 & -0.440180 \\ \mathrm{H} & -4.374498 & -4.610526 & -0.627159 \\ \mathrm{H} & -5.063410 & -3.093473 & -1.220576 \\ \mathrm{H} & -4.955149 & -3.385051 & 0.511513 \\ \mathrm{C} & -3.061235 & -1.802421 & 2.297678 \\ \mathrm{H} & -3.790648 & -1.462916 & 3.035377\end{array}$




$\begin{array}{lccc}\text { H } & -3.377736 & -2.799584 & 1.992802 \\ \mathrm{C} & -1.586468 & -2.177439 & 4.331908 \\ \mathrm{C} & 0.359922 & -1.824089 & 3.294401 \\ \mathrm{C} & -0.219276 & -2.122202 & 4.546345 \\ \mathrm{H} & 0.292647 & -2.332805 & 5.472524 \\ \mathrm{C} & -2.663122 & -2.460508 & 5.298558 \\ \mathrm{C} & -3.684386 & -3.389358 & 5.036421 \\ \mathrm{H} & -3.694400 & -3.929623 & 4.095056 \\ \mathrm{C} & -4.664487 & -3.654974 & 5.991639 \\ \mathrm{H} & -5.442996 & -4.380336 & 5.774963 \\ \mathrm{C} & -4.636576 & -3.005775 & 7.226771 \\ \mathrm{H} & -5.398968 & -3.216144 & 7.970602 \\ \mathrm{C} & -3.619627 & -2.090174 & 7.503589 \\ \mathrm{H} & -3.589093 & -1.583286 & 8.463356 \\ \mathrm{C} & -2.642289 & -1.818205 & 6.548521 \\ \mathrm{H} & -1.858128 & -1.097914 & 6.759931 \\ \mathrm{C} & 1.790952 & -1.662825 & 2.993122 \\ \mathrm{C} & 2.331286 & -2.031496 & 1.748366 \\ \mathrm{H} & 1.686150 & -2.483269 & 0.999136 \\ \mathrm{C} & 3.691023 & -1.862315 & 1.490496 \\ \mathrm{H} & 4.110596 & -2.131035 & 0.527976 \\ \mathrm{C} & 4.537693 & -1.340408 & 2.473383 \\ \mathrm{H} & 5.585305 & -1.193404 & 2.245726 \\ \mathrm{C} & 4.009723 & -0.987980 & 3.716451 \\ \mathrm{H} & 4.659777 & -0.576909 & 4.483256 \\ \mathrm{C} & 2.648886 & -1.142462 & 3.975248 \\ \mathrm{H} & 2.241444 & -0.840091 & 4.935937 \\ \mathrm{~F} & 0.141173 & 0.000684 & -0.000042 \\ \mathrm{H} & 1.164710 & 0.000085 & 0.000713 \\ \mathrm{H} & -0.195741 & -0.606338 & 0.781664 \\ \mathrm{H} & -0.194420 & 0.981675 & 0.134695 \\ \mathrm{H} & -0.194362 & -0.372800 & -0.917113 \\ \mathrm{~F} & 7.393855 & -0.000152 & 0.001061 \\ \mathrm{~F} & 8.303927 & -0.709804 & -1.140351 \\ \mathrm{~F} & -303483 & -0.633770 & 1.186695 \\ \mathrm{~F} & -343487 & -0.042657 \\ \mathrm{~F} & 0.705188 & 1.137309 \\ \mathrm{~F} & -1.337262 & 0.043734\end{array}$




\subsubsection{Crystallographic data}

X-ray quality colorless crystals of 2 were obtained by slow evaporation of a $\mathrm{CH}_{2} \mathrm{Cl}_{2}$ solution of $\mathbf{2}$, while colorless crystals of $\left[\mathbf{2} \cdot \mathrm{NH}_{4}\right]^{+} \mathrm{PF}_{6}$ were obtained by slow $\mathrm{Et}_{2} \mathrm{O}$ vapor diffusion into a $\mathrm{MeOH}$ solution of the compound. Single crystal X-ray data were collected on a Bruker D8 Quest instrument equipped with a CMOS detector and integrated using the APEX3 suite. ${ }^{36}$ The structures were solved by intrinsic phasing methods available with SHELXT and were refined by full-matrix least-squares using SHELXL and SHELXS packages $^{37}$ using Olex $2^{38}$ or ShelXle ${ }^{39}$. Multi-scan absorption correction was performed using SADABS. ${ }^{40}$ Crystallographic data have been submitted to the Cambridge Crystallographic Data Center (CCDC numbers: 1550637 (2) and $1550636\left(\left[2 \cdot \mathrm{NH}_{4}\right] \mathrm{PF}_{6}\right)$ and can be obtained free of charge from www.ccdc.cam.ac.uk/data request/cif. Crystallographic data are provided in Table 2. and the X-ray crystal structures are shown in Figures 2.8 and 2.9. The phenyl rings on the diphenyl pyrazole were thermally disordered and were refined using the SPLIT routine available within Olex2 program and using PARTS. ${ }^{38}$ The $\mathrm{PF}_{6}$ ion was disordered over two positions and was refined using PARTS using ShelXle. ${ }^{39}$ 
Table 2.2. Crystallographic data.

\begin{tabular}{|c|c|c|}
\hline & 2. $\mathrm{NH}_{4} \mathrm{PF}_{6}$ & 2 \\
\hline Chemical formula & $\mathrm{C}_{60} \mathrm{H}_{58} \mathrm{~N}_{7} \cdot \mathrm{PF}_{6}$ & $\mathrm{C}_{60} \mathrm{H}_{54} \mathrm{~N}_{6}$ \\
\hline$M_{\mathrm{r}}$ & 1022.10 & 859.09 \\
\hline $\begin{array}{l}\text { Crystal system, space } \\
\text { group }\end{array}$ & Trigonal, $R-3$ (No. 148) & Triclinic, $P-1$ (No. 2) \\
\hline Temperature $(\mathrm{K})$ & 301 & 297 \\
\hline$a, b, c(\AA)$ & $\begin{array}{l}14.7935(5), 14.7935(5), \\
42.5752(16)\end{array}$ & $\begin{array}{l}10.5434(4), 12.4141(5), \\
19.6118(8)\end{array}$ \\
\hline$\alpha, \beta, \gamma\left({ }^{\circ}\right)$ & $90,90,120$ & $\begin{array}{l}94.867(1), 102.526(1), \\
106.638(1)\end{array}$ \\
\hline$V\left(\AA^{3}\right)$ & $8069.2(6)$ & $2371.1(2)$ \\
\hline $\bar{Z}$ & 6 & 2 \\
\hline Radiation type & Mo $K \alpha$ & $\operatorname{Mo~} K \alpha$ \\
\hline$\mu\left(\mathrm{mm}^{-1}\right)$ & 0.12 & 0.071 \\
\hline Crystal size (mm) & $0.16 \times 0.14 \times 0.11$ & $0.327 \times 0.227 \times 0.046$ \\
\hline Diffractometer & Bruker D8 Quest & Bruker D8 Quest \\
\hline Absorption correction & SADABS & SADABS \\
\hline $\begin{array}{l}\text { No. of measured and } \\
\text { independent reflections }\end{array}$ & 32938,3756 & 41715,9430 \\
\hline$R_{\text {int }}$ & 0.0700 & 0.0701 \\
\hline $\begin{array}{l}R\left[F^{2}>\right. \\
\left.2 \sigma\left(F^{2}\right)\right], w R\left(F^{2}\right), S\end{array}$ & $0.082,0.212,1.033$ & $0.0672,0.1287,1.007$ \\
\hline $\begin{array}{l}\text { No. of observed } \\
\text { reflections }(\mathrm{I}>2 \square(\mathrm{I}))\end{array}$ & 2196 & 4462 \\
\hline$\Delta \rho_{\max }, \Delta \rho_{\min }\left(\mathrm{e} \AA^{-3}\right)$ & $0.75,-0.27$ & $0.29 /-0.17$ \\
\hline
\end{tabular}




\subsection{References}

1. Späth, A.; König, B. Molecular recognition of organic ammonium ions in solution using synthetic receptors. Beilstein J. Org. Chem. 2010, 6, 1-111.

2. Wolfbeis, O. S.; Li, H. Fluorescence optical urea biosensor with ammonium optrode as transducer. Biosens. Bioelectron. 1993, 8, 161-166.

3. Rhines, T. D.; Arnold, M. A. Fiber-Optic biosensor for urea based on sensing of ammonia gas. Anal. Chim. Acta, 1989, 227, 387-396.

4. Bühlmann, P.; Pretsch E.; Bakker, E. Carrier-Based Ion-Selective Electrodes and Bulk Optodes. 2. Ionophores for Potentiometric and Optical Sensors. Chem. Rev. 1998, 98, 1593-1688.

5. Rueda-Zubiaurre, A.; Herrero-García, N.; del Rosario Torres, M.; Fernández, I.; Osío Barcina, J. Rational design of a nonbasic molecular receptor for selective $\mathrm{NH}_{4}{ }^{+} / \mathrm{K}^{+}$complexation in the gas phase. Chem. Eur. J. 2012, 18, 16884-16889.

6. Kim H. S.; Kim D.H.; Kim K. S.; Choi H. J.; Shim J. H.; Jeong I. S.; Cha G. S.; Nam H. Synthesis and properties of 1,3,5-tris(phenoxymethyl)-2,4,6triethylbenzenes as $\mathrm{NH}_{4}{ }^{+}$ionophores. J. Incl. Phenom. Macrocycl. Chem. 2003, 46, 201-205.

7. Suzuki, K.; Siswanta, D.; Otsuka,K.; Amano,T.; Ikeda, T.; Hisamoto, H.; Yoshihara, R. Ohba, S. Design and Synthesis of a highly selective ammonium ionophore than nonactin and its application as an ion-sensing Component for an ion-selective electrode. Anal. Chem. 2000, 72, 2200-2205.

8. Kim, H. S.; Park, H. J.; Oh, H. J.; Koh, Y. K.; Choi, J.H.; Lee, D.H.; Cha, G.S.; Nam, H. Thiazole-Containing Benzo-Crown Ethers: A New Class of AmmoniumSelective Ionophores. Anal. Chem. 2000, 72, 4683-4688.

9. (a) Kim, H.S.; Kim, D.H.; Kim, K. S.; Choi, J. H.; Choi, H. J.; Kim, S. H.; Shim, J. H.; Cha G. S.; Nam, H. Cation selectivity of ionophores based on tripodal thiazole derivatives on benzene scaffold. Talanta, 2007, 71, 1986-1992. (b) Rüdiger, V.; Schneider, H. J.; Solov'ev, V. P.; Kazachenko, V. P.; Raevsky, O. A. Crown Ether-Ammonium Complexes: Binding Mechanisms and Solvent Effects. Eur. J. Org. Chem., 1999, 1999, 1847-1856.

10. (a) Rahman, A.; Kwon, N. H.; Won, M.S.; Hyun, M.H.; Shim, Y. B. Selective Binding of $\mathrm{NH}_{4}{ }^{+}$by Redox-Active Crown Ethers: Application to a $\mathrm{NH}_{4}{ }^{+}$Sensor. Anal. Chem. 2004, 76, 3660-3665. (b) Graf, E.; Kintzinger, J. P.; Lehn, J. M.; LeMoigne, J. Molecular recognition: Selective ammonium cryptates of synthetic 
receptor molecules possessing a tetrahedral recognition site. J. Am. Chem. Soc. 1982, 104, 1672-1678.

11. Kuswandi, B.; Nuriman, Verboom, W.; Reinhoudt, D. N. Tripodal receptors for cation and anion sensors. Sensors, 2006, 6, 978-1017.

12. Bill, N. L.; Kim, D. S.; Kim, S. K.; Park, J. S.; Lynch, V. M.; Young, N.J.; Hay, B. P.; Yang, Y.; Anslyn, E. V.; Sessler. J.L. Oxoanion recognition by benzenebased tripodal pyrrolic receptors. Supramol. Chem. 2012, 24, 72-76.

13. Jon, S. Y.; J. Kim, M. Kim, S. Park, W. S. Jeon, J. Heo and K. Kim, A Rationally Designed $\mathrm{NH}^{+}$Receptor Based on Cation-pi Interaction and Hydrogen Bonding. Angew. Chem. Int. Ed., 2001, 40, 2116-2119.

14. Ahn, K. H.; Kim, S. G.; Jung, J.; Kim, K.-H.; Kim, J.; Chin, J.; Kim, K. Selective Recognition of $\mathrm{NH}_{4}{ }^{+}$over $\mathrm{K}^{+}$with Tripodal Oxazoline Receptors. Chem. Lett., 2000, 29, 170-171.

15. Ahn, K. H.; Ku, H. Y.; Kim, Y.; Kim, S. G.; Kim, Y. K.; Son H. S.; Ku, J. K. Fluorescence Sensing of Ammonium and Organoammonium Ions with Tripodal Oxazoline Receptors. Org. Lett., 2003, 5, 1419-1422.

16. Tsitovich, P. B.; Spernyak, J. A.; Morrow J. R.; A Redox-Activated MRI Contrast Agent that Switches Between paramagnetic and Diamagnetic States. Angew. Chem. Int. Ed., 2013, 52, 13997-14000.

17. (a) Chin, J.; Oh, J.; Jon, S. Y.; Park, S. H.; Walsdorff, C.; Stranix, B.; Ghoussoub, A.; Lee, S.J.; Chung, H. J.; Park, S-M.; Kim. K. Tuning and Dissecting Electronic and Steric Effects in Ammonium Receptors: Nonactin vs Artificial Receptors. $J$. Am. Chem. Soc. 2002, 124, 5374-5379. (b) Chin, J.; Walsdorff, C.; Stranix, B.; Oh, J.; Chung, H. J.; Park, S. M.; Kim, K. A Rational Approach to Selective Recognition of $\mathrm{NH}^{+}{ }^{+}$over $\mathrm{K}^{+}$. Angew. Chemie - Int. Ed. 1999, 38, 2756-2759.

18. Koch, N.; Mazik, M. Synthesis of Tripodal and Hexapodal Pyrazole- and Benzimidazole-Bearing Compounds. Synthesis (Stuttg). 2013, 45, 3341-3348.

19. K. A. Connors, Binding Constants, John Wiley \& Sons, New York, 1st ed., 1987.

20. Mercer, D. J.; Loeb. S. J.; Metal-based Anion Receptors; An Application of Second Sphere Coordination. Chem. Soc. Rev. 2010, 39, 3612-3620.

21. Mäkelä, T.; Kalenius, E.; Rissanen, K.; Cooperatively Enhanced Ion pair Binding with a Hybrid Receptor. Inorg. Chem. 2015, 54, 9154-9165.

22. Higuchi, T.; Rytting, J. H. Thermodynamic group contributions from ion pair extraction equilibriums for use in the prediction of partition coefficients. 
Correlation of surface area with group contributions. J. Phys. Chem., 1973, 77, 2694-2703.

23. Levitskaia , T. G.; Bryan , J. C.; Sachleben , R. A.; Lamb , J. D.; Moyer, B. A. A Surprising Host-Guest Relationship between 1,2-Dichloroethane and the Cesium Complex of Tetrabenzo-24-Crown-8. J. Am. Chem. Soc., 2000, 122, 554-562.

24. Kim, S. K.; Sessler, J. L.; Gross, D. E.; Lee, C.; Kim, J. S.; Lynch, V. M.; Delmau , L. H.; Hay, B. P. A calix[4]arene strapped calix[4]pyrrole: An ion-pair receptor displaying three different cesium cation recognition modes. J. Am. Chem. Soc., 2010, 132, 5827-5836.

25. Levitskaia, T.G.; Maya, L.; Van Berkel, G. J.; Moyer, B. A.; Anion Partitioning and Ion-Pairing Behavior of Anions in the Extraction of Cesium Salts by 4,5"bis(tert-octylbenzo)dibenzo-24-crown-8 in 1,2-Dichloroethane. Inorg. Chem., 2007, 46, 261-272.

26. Jia, C.; Wang, Q.-Q.; Begum, R. A.; Day, V. W.; Bowman-James, K.; Chelate effects in sulfate binding by amide/urea-based ligands; Org. Biomol. Chem. 2015, 13, 6953-6957.

27. Vacca, A.; Nativi, C.; Cacciarini, M.; Pergoli R.; Roelens, S. A New Tripodal Receptor for Molecular Recognition of Monosaccharides. A Paradigm for Assessing Glycoside Binding Affinities and Selectivities by ${ }^{1} \mathrm{H}$ NMR Spectroscopy. J. Am. Chem. Soc., 2004, 126, 16456-16465.

28. Arunachalam, M.; B. N.; Ahamed, Ghosh, P. Binding of Ammonium Hexafluorophosphate and Cation-Induced Isolation of Unusual Conformers of a Hexapodal Receptor Org. Lett., 2010, 12, 2742-2745.

29. KaleidaGraph, Version 3.0.2. Synergy Software (PCS Inc.), Reading, PA 19606. Developed by Abelbeck Software Inc.

30. Becke, A. D. Density-Functional Thermochemistry. III. The Role of Exact Exchange. J. Chem. Phys. 1993, 98, 5648-5652

31. Lee, C.; Yang, W.; Parr, R. G. Development of the Colle-Salvetti CorrelationEnergy Formula into a Functional of the Electron Density. Phys. Rev. B 1988, 37, 785-789.

32. Hehre, W.J.; Ditchfield, R.; Pople, J.A. Self-consistent molecular orbital methods. XII. Further extensions of gaussian-type basis sets for use in molecular orbital studies of organic molecules. J. Chem. Phys. 1972, 56, 2257-2261.

33. Francl, M. M.; Pietro, W. J.; Hehre, W. J.; Binkley, J. S.; Gordon, M. S.; DeFrees, D. J.; Pople, J. A. Self-Consistent Molecular Orbital Methods. XXIII. A 
Polarization-type Basis Set for Second-Row Elements. J. Chem. Phys. 1982, 77, 3654-3665

34. Frisch, M. J.; Trucks, G. W.; Schlegel, H. B.; Scuseria, G. E.; Robb, M. A.; Cheeseman, J. R.; Scalmani, G.; Barone, V.; Mennucci, B.; Petersson, G. A. Gaussian 09, Revision A.1; Gaussian, Inc., Wallingford CT, 2009

35. Tomasi, J.; Mennucci, B.; Cammi, R. Quantum mechanical continuum solvation models. Chem. Rev. 2005, 105, 2999-3094.

36. APEX3, Bruker Inc., Madisson, WI, 2017.

37. Sheldrick, G. M. Crystal structure refinement with SHELXL. Acta Crystallogr. Sect. C, 2015, C71, 3-8.

38. Dolomanov, O. V.; Bourhis, L. J.; Gildea, R. J.; Howard J. A. K.; Puschmann. H. OLEX2: A complete structure solution, refinement and analysis program. J. Appl. Cryst. 2009, 42, 339-341.

39. Hubschle, C. B.; Sheldrick, G. M.; Dittrich, B. ShelXle: a Qt graphical user interface for SHELXL. J. Appl. Crystal. 2011, 44, 1281-1284.

40. Krause, L.; Herbst-Irmer, R.; Sheldrick, G. M.; Stalke, D. Comparison of silver and molybdenum microfocus X-ray sources for single-crystal structure determination. J. Appl. Crystal. 2015, 48, 3-10. 


\title{
Chapter III
}

\section{Selective ion-pair fluorescent sensing of}

ammonium nitrate by a combination of pyrazolyl and dansyl tripodal extractants

\author{
Tosin M. Jonah, Richild A. Currie and Konstantinos Kavallieratos* \\ Department of Chemistry and Biochemistry, Florida International University, \\ 11200 SW $8^{\text {th }}$ Street, CP 326, Miami, Florida 33199
}




\subsection{Abstract}

Dual-host combination of cation and anion sensors is used for the detection of ion pairs via solvent extraction. Selective sensors for each ion were synthesized and used together for ion-pair sensing both in organic solvents (using $(n-\mathrm{Bu})_{4} \mathrm{~N}^{+} \mathrm{NO}_{3}{ }^{-}$and $\left.\mathrm{NH}_{4}{ }^{+} \mathrm{PF}_{6}{ }^{-}\right)$and in extraction of ammonium nitrate from water, into dichloromethane. We have demonstrated a unique extraction-based ion pair sensing method using FRET, which is selective for $\mathrm{NH}_{4} \mathrm{NO}_{3}$ at the $1.0 \times 10^{-5} \mathrm{M}$ to $1.0 \times 10^{-4} \mathrm{M}$ concentration range. The pendant pyrazolyl fluorophore groups of $\mathbf{1}$ which emit at 305-340 $\mathrm{nm}$ range are compatible with the excitation wavelength of the dansyl fluorophore in $\mathbf{2}$, thus resulting in FRET upon combined use of these receptors. Extraction results revealed FRET fluorescence enhancements at $510 \mathrm{~nm}$, with increasing concentration of $\mathrm{NH}_{4} \mathrm{NO}_{3}$ while $\mathrm{NaNO}_{3}, \mathrm{KNO}_{3}, \mathrm{NaCl}$ and $\mathrm{KCl}$ showed no fluorescence responses.

\subsection{Introduction}

Ion-pair sensing, which is concurrent complexation and detection of both the cation and anion species is an area that faces challenges in supramolecular chemistry. ${ }^{1}$ Selective receptors have been developed for the sensing of cationic and anionic species separately but the challenge faced by chemists is the combined co-extraction and selective sensing of both ionic components of inorganic salts simultaneously.

Ion pairing has found many uses in the development of membrane transport, salt extraction and sensors. ${ }^{2}$ Ion-pair receptors can be classified on the basis of how they bind to the ion pair components, which can be either independently or in a combined fashion.

Ditopic receptors bind both salt components within the same molecule. ${ }^{1,3-7}$ Reetz and coworkers demonstrated this by coupling a crown ether moiety designed for $\mathrm{K}^{+}$recognition 
to a Lewis-acidic boron center designed for $\mathrm{F}^{-}$recognition. ${ }^{8}$ The design of ditopic receptors comes with some unique synthetic challenges. The cation-binding site must be separated from the anion-binding site in a way that the two sites do not interfere with each other. Selectivity of these sites for the target ion-pair over all possible interfering ion pairs must also be considered when designing the ditopic receptor. The design of the individual binding sites is somewhat straightforward, and the methods for creating individual hosts can be applied here. The difficulty lies in the linking of the two binding sites, which could be a complex process and a synthetic challenge. Another approach to ion-pair sensing which has been explored by fewer researchers is the dual-host strategy, ${ }^{9-11}$ in which two different receptors specific for each ion are used to achieve combined sensing. The ion pairing in an organic solvent of relatively low dielectric constant can produce synergistic effects and in the case of fluorescent sensing, provide unique sensing effects for the pair as opposed to the individual components, through close contact of the complexed pair components in the organic solvent. For example if a fluorophore in the cation binding host has an emission band compatible with the excitation wavelength of the fluorophore attached to the anion receptor, close contact of the two complexed ions in the organic phase should -in principle- result in unique FRET emissions. Another advantage of the dual host strategy over the heteroditopic receptor is the avoidance of the laborious steps in synthesis of ditopic receptors. The dual host approach involves the combined extraction and sensing of the ion pair by two separate receptors using an organic solvent, such as 1,2dichloroethane.

Different dual host receptors have been used for the extraction of alkali metal salts. An example is the liquid-liquid extraction of $\mathrm{KF}$ or $\mathrm{KCl}$ into $\mathrm{CHCl}_{3}$ from an aqueous phase 
containing equimolar amounts of cation and anion receptors. ${ }^{12}$ 18-Crown- 6 and a tripodal amide were the receptor choices for cation and anion binding, respectively. From the Xray crystal structure obtained, it was shown that upon ion-pair complexation, the potassium salts self assemble to form a 1-D coordination polymer. In another example, Das et al. combined a N-bridged tripodal urea receptor for anions with 18-crown for binding and selfassembly of a $\mathrm{K}_{2} \mathrm{CO}_{3}$ complex. ${ }^{13}$ Despite these and other efforts, the dual-host strategy has not yet to our knowledge been applied successfully for sensing specific ion pairs.

In our effort to expand this dual host approach into selective sensing, we chose the ammonium nitrate ion pair, as a prototype. Ammonium nitrate was chosen because it is a sought-after material by terrorists for making improvised explosive devices, and it is commonly obtained in large quantities by commercial vendors, because ammonium salts are often use as fertilizers. Fluorescence detection presents a sensitive, inexpensive, and potentially portable method for in-field explosive detection. The pyrazolyl and dansyl fluorophores in receptors 1 and 2 (Fig. 3.1) for $\mathrm{NH}_{4}{ }^{+}$and $\mathrm{NO}_{3}{ }^{-}$, respectively, were chosen because of the compatibility of their fluorescence excitation and emission wavelengths respectively, so that FRET will be observed upon salt extraction in the organic phase. The pendant pyrazolyl fluorophore groups of $\mathbf{1}$ which emit at 305-340 nm range are compatible with the excitation wavelength of the dansyl fluorophore in $\mathbf{2}$ thus resulting in FRET upon combined use of these receptors. The low dielectric constant of the organic medium assures close contact of the complexed anion and cation after extraction, which may lead to unique sensing effects as a result of FRET. 


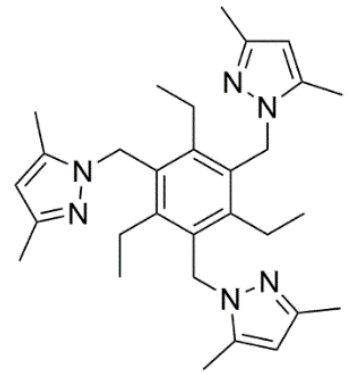

1

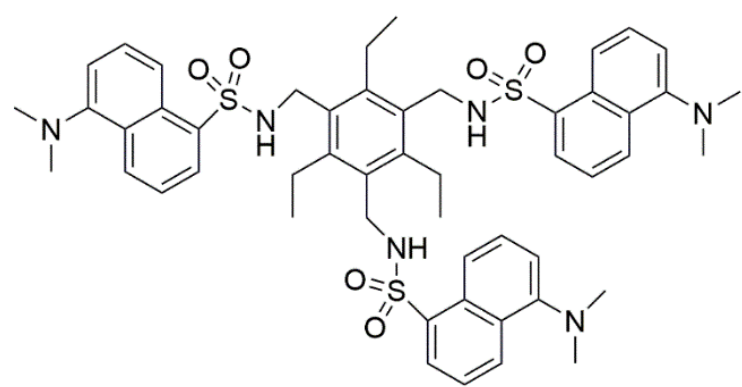

2

Figure 3.1 Chemical structures of ligands $\mathbf{1}$ and $\mathbf{2}$.

\subsection{Results and Discussion}

There have been a few reported receptors for $\mathrm{NH}_{4}{ }^{+}$cation binding and sensing. ${ }^{14-20}$ The selected ammonium receptor is a fluorescent tripodal pyrazole, $\mathbf{1}$, previously synthesized by J. Chin and co-workers. ${ }^{14}$ In our effort to understand the dual-host system, we studied the $\mathrm{NH}_{4}{ }^{+}$binding properties of $\mathbf{1}$ by fluorescence and ${ }^{1} \mathrm{H}-\mathrm{NMR}$ titrations. Fluorescence titration of 1 in $\mathrm{CH}_{3} \mathrm{CN} / \mathrm{CH}_{2} \mathrm{Cl}_{2}(1: 1)$ with $\mathrm{NH}_{4} \mathrm{PF}_{6}$ at constant receptor concentration (1.0 $\mathrm{x} 10^{-4} \mathrm{M}$ ) showed an increase in fluorescence upon addition of $\mathrm{NH}_{4} \mathrm{PF}_{6}$, which is significantly higher for $\mathrm{NH}_{4}^{+} v s . \mathrm{K}^{+}$, a pattern similar to the one observed for analogous tripodal oxazolines. ${ }^{15 a}$ The results obtained from the ${ }^{1} \mathrm{H}-\mathrm{NMR}$ titrations revealed remarkably strong and selective binding for $\mathrm{NH}_{4}^{+}\left(\mathrm{K}_{\mathrm{a}}=74000 \mathrm{M}^{-1}\right)$, over $\mathrm{K}^{+}\left(\mathrm{K}_{\mathrm{a}}=15 \mathrm{M}^{-1}\right)$ and 1:1 binding stoichiometry. (See Chapter 2 for details).

For the nitrate ion, we utilized 2, a rigid 1,3,5-tris-(dansylsulfonamidomethyl)-2,4,6triethlbenzene framework previously synthesized in our group. ${ }^{15 b}$ The anion binding properties of $\mathbf{2}$ were determined in $\mathrm{CDCl}_{3}$ by ${ }^{1} \mathrm{H}-\mathrm{NMR}$ titration experiments using $(n-\mathrm{Bu})_{4} \mathrm{~N}^{+} \mathrm{NO}_{3}{ }^{-}$. Significant downfield shifts of the N-H proton resonance were observed, indicating anion binding via hydrogen bonding. The titration studies were also performed 
for other anions, such as $\mathrm{Cl}^{-}, \mathrm{Br}^{-}$and $\mathrm{I}^{-}$. The ${ }^{1} \mathrm{H}-\mathrm{NMR}$ titration results indicate that receptor 2 binds stronger to $\mathrm{NO}_{3}{ }^{-}$compared to $\mathrm{Cl}^{-}, \mathrm{Br}^{-}$and $\mathrm{I}^{-}$. A single $\mathrm{N}-\mathrm{H}$ resonance was observed, in all the experiments, indicating the involvements of all three $\mathrm{N}-\mathrm{H}$ protons in anion binding or a fast exchange of $\mathrm{NH}^{\cdots} \mathrm{X}^{-}$anion complexes with number of hydrogen bonds. Non-linear regression analysis using the 1:1 binding isotherm (Eq. 1), was used in the determination the association constant $\mathrm{K}_{\mathrm{a}}$, which showed the formation of a 1:1 complex, where $\Delta \delta$ is the change in the $\mathrm{N}-\mathrm{H}$ resonance, $\delta_{\text {obs }}$ is the observed change in the $\mathrm{N}-\mathrm{H}$ resonance, $\delta \mathbf{R}$ is the actual change in the $\mathrm{N}-\mathrm{H}$ resonance, $[\mathbf{R}]_{\mathrm{t}}$ is the total concentration of $\mathbf{R},\left[\mathrm{X}^{-}\right]_{\mathrm{t}}$ is the total concentration of $(n-\mathrm{Bu})_{4} \mathrm{~N}^{+} \mathrm{X}^{-}, \mathrm{K}_{\mathrm{a}}$ is the association constant, and $\Delta \delta_{\max }$ is the maximum chemical shift change. Non-linear regression analysis of the binding isotherms obtained from these shifts gave a 1:1 association constant $\mathrm{K}_{\mathrm{a}}$ of $146( \pm 3.9) \mathrm{M}^{-1}$ for the formation of $\mathbf{2} \cdot \mathrm{NO}_{3}{ }^{-}$vs. $43 \mathrm{M}^{-1}$ for $\mathbf{2} \cdot \mathrm{Cl}$ - and $91 \mathrm{M}^{-1}$ for $\mathbf{2} \cdot \mathrm{I}^{-}$.

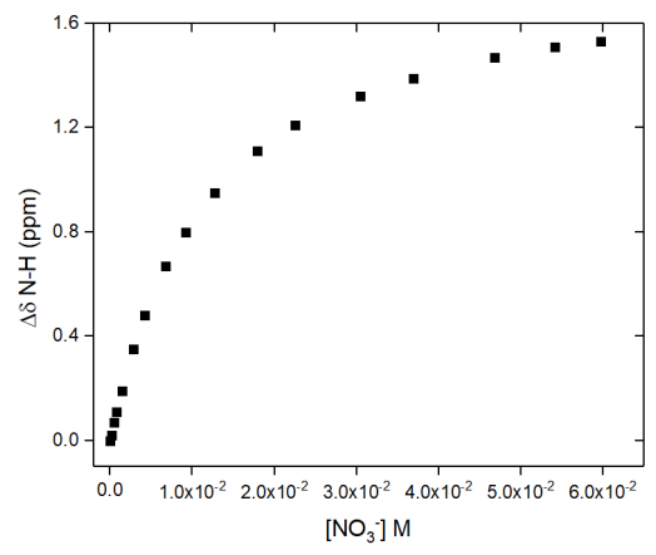

Figure 3.2. ${ }^{1} \mathrm{H}-\mathrm{NMR}$ titration of 2 with $(n-\mathrm{Bu})_{4} \mathrm{~N}^{+} \mathrm{NO}_{3}{ }^{-}$in $\mathrm{CD}_{2} \mathrm{Cl}_{2}$. The concentration of 2 was kept constant at $2 \mathrm{mM}$. 
The dansyl group present in the structure of $\mathbf{2}$ provides the avenue for performing sensing studies with the receptor and the nitrate ion. Fluorescence titrations of 2 with $(n-\mathrm{Bu})_{4} \mathrm{~N}^{+} \mathrm{NO}_{3}^{-}$at constant receptor concentration $\left(1.0 \times 10^{-6} \mathrm{M}\right)$ were carried out in $\mathrm{CH}_{2} \mathrm{Cl}_{2}$ with $\lambda_{\text {exc }}=352 \mathrm{~nm}$. Addition of $(n-\mathrm{Bu})_{4} \mathrm{~N}^{+} \mathrm{NO}_{3}{ }^{-}$to 2 showed a decrease in fluorescence upon nitrate binding (Figure 3.3).

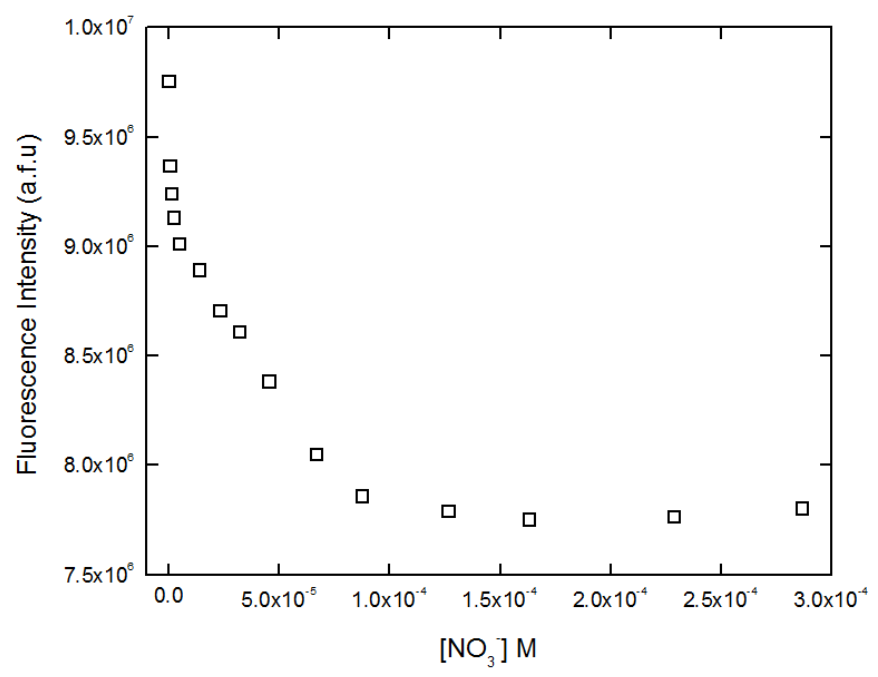

Figure 3.3. Fluorescence titration $\left(\lambda_{\mathrm{exc}}=352 \mathrm{~nm}\right)$ of $2\left(1.0 \times 10^{-6} \mathrm{M}\right)$ with $\left(1.0 \times 10^{-3} \mathrm{M}\right)$ of $(n-\mathrm{Bu})_{4} \mathrm{~N}^{+} \mathrm{NO}_{3}^{-}$in $\mathrm{CH}_{2} \mathrm{Cl}_{2}$. The concentration of 2 was kept constant.

The dual-host approach for sensing ion pairs involves the use of two separate receptors each for the individual ions in the ion pair. We used two approaches in investigating the dual-host sensing: We initially carried out fluorescence titrations studies in mixed solutions of 1 and 2, in an organic solvent $\left(\mathrm{CH}_{3} \mathrm{OH} / \mathrm{CH}_{2} \mathrm{Cl}_{2} 2: 8\right)$ with mixed solutions of $(n-\mathrm{Bu})_{4} \mathrm{~N}^{+} \mathrm{NO}_{3}{ }^{-}$and $\mathrm{NH}_{4}{ }^{+} \mathrm{PF}_{6}{ }^{-}$. The fluorescence emission spectra were collected at $\lambda_{\text {exc }}=$ $272 \mathrm{~nm}$, which corresponds to the excitation wavelength of $\mathbf{1}$. Excitation of $\mathbf{1}$ at $\lambda_{\mathrm{exc}}=272$ $\mathrm{nm}$ resulted in the transfer of energy from excited $\mathbf{1}$ to $\mathbf{2}$ raising the energy state of an electron in $\mathbf{2}$ to higher vibrational levels of the excited singlet state. As a result, the energy level of the 1 returns to the ground state, without emitting its own fluorescence. The 
resulted fluorescence quenching signal is shown below in figure 3.4 while figure 3.5 shows quenching at $506 \mathrm{~nm}$ wavelength. What is notable from these experiments is that dansyl FRET fluorescence is clearly observed upon excitation at $272 \mathrm{~nm}$, only in the presence of the pyrazolyl fluorophore. As the excitation of the dansyl fluorophore is in the $310-352 \mathrm{~nm}$ range, this experiment shows that in principle FRET fluorescence by the interaction of the two fluorophores in the organic phase could be used to monitor $\mathrm{NH}_{4} \mathrm{NO}_{3}$ quantities. Yet the presence of FRET fluorescence even in the absence of any $\mathrm{NH}_{4} \mathrm{NO}_{3}$, presumably because of association between the two receptors, may present a potential problem. In the event that only the dansyl receptor $\mathbf{2}$ is used no fluorescence emission is observed upon excitation at $272 \mathrm{~nm}$. Likewise, in the absence of the dansyl receptor 2, excitation of solutions of 1, gave fluorescence at $298 \mathrm{~nm}$, but no FRET emissions at $506 \mathrm{~nm}$.

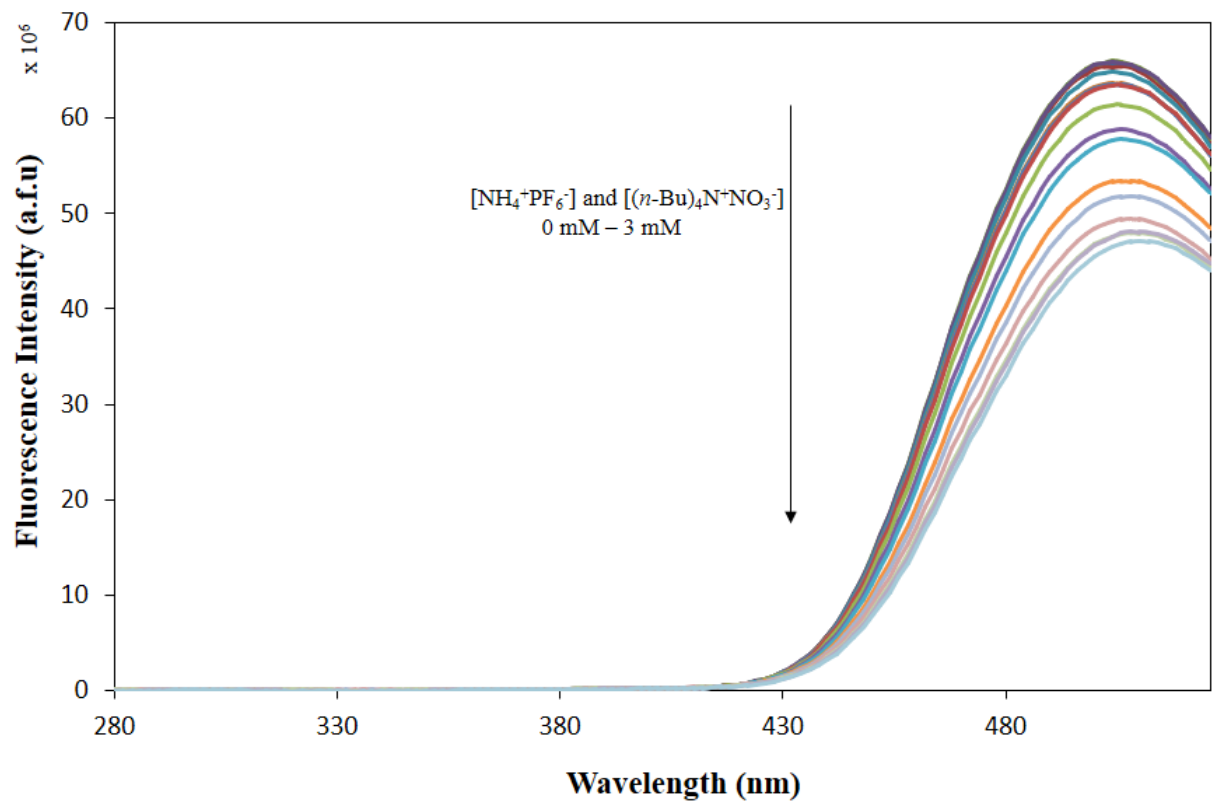

Figure 3.4. Fluorescence titrations of an equimolar mixture of 1 and $2\left(5.0 \times 10^{-5} \mathrm{M}\right)$ with an equimolar mixture of $\mathrm{NH}_{4}{ }^{+} \mathrm{PF}_{6}{ }^{-}$and $(n-\mathrm{Bu})_{4} \mathrm{~N}^{+} \mathrm{NO}_{3}{ }^{-}$in $\mathrm{CH}_{3} \mathrm{OH} / \mathrm{CH}_{2} \mathrm{Cl}_{2}$ (2:8). 


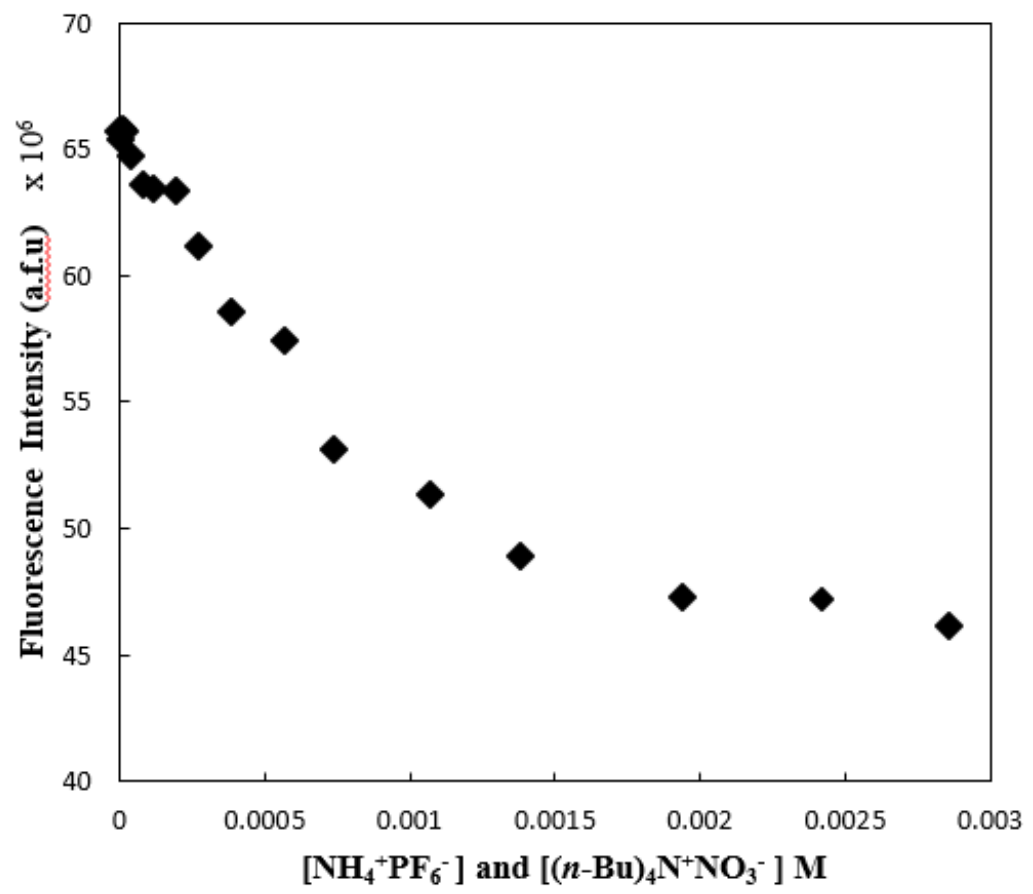

Figure 3.5. Fluorescence Titration curve of $1 \& 2$ with $\mathrm{NH}_{4}{ }^{+} \mathrm{PF}_{6}{ }^{-} \&(n-\mathrm{Bu})_{4} \mathrm{~N}^{+} \mathrm{NO}_{3}{ }^{-}$ $\lambda_{\text {exc }}=272 \mathrm{~nm}, \lambda_{\text {em }}=506 \mathrm{~nm}$.

Our investigation was expanded into the combined extraction and sensing of $\mathrm{NH}_{4} \mathrm{NO}_{3}$ by $\mathbf{1}$ and $\mathbf{2}$ using an organic solvent, dichloromethane. A dual-host extraction experiment was designed in which the tripodal pyrazolyl receptor $\mathbf{1}$ for $\mathrm{NH}_{4}{ }^{+}$and the dansylated sulfonamide 2 , for $\mathrm{NO}_{3}{ }^{-}$were used in the organic phase to extract different alkali metal sallts from aqueous phases, and the fluorescence spectra were recorded after contact, phase separation, and drying of the organic phase with granular $\mathrm{Na}_{2} \mathrm{SO}_{4}$. Specifically, the organic phases contained both 1 and $2\left(5.0 \times 10^{-5} \mathrm{M}\right)$ in $\mathrm{CH}_{2} \mathrm{Cl}_{2}$. Stock solutions of $\mathrm{NaNO}_{3}, \mathrm{KNO}_{3}$, $\mathrm{NH}_{4} \mathrm{NO}_{3}, \mathrm{KCl}$, and $\mathrm{NaCl}$, in ultrapure water $\left(1.0 \times 10^{-2} \mathrm{M}\right)$ were brought in contact with the organic phases. The organic layers were separated from the aqueous layer after $3 \mathrm{~h}$. The fluorescence intensity of the organic layers was measured after separation and drying of the organic phases. All the solutions were excited at $272 \mathrm{~nm}$ with the slit at $1 \mathrm{~nm}$. Extraction 
results revealed fluorescent enhancements with increasing concentration of $\mathrm{NH}_{4} \mathrm{NO}_{3}(\mathrm{Fig}$. 3.6). The control extraction experiments repeated for $\mathrm{NaNO}_{3}, \mathrm{KNO}_{3}, \mathrm{NaCl}$ and $\mathrm{KCl}$ (Fig. 3.7-3.10) showed no significant fluorescence responses when this salts were extracted by receptor $1 \& 2$.

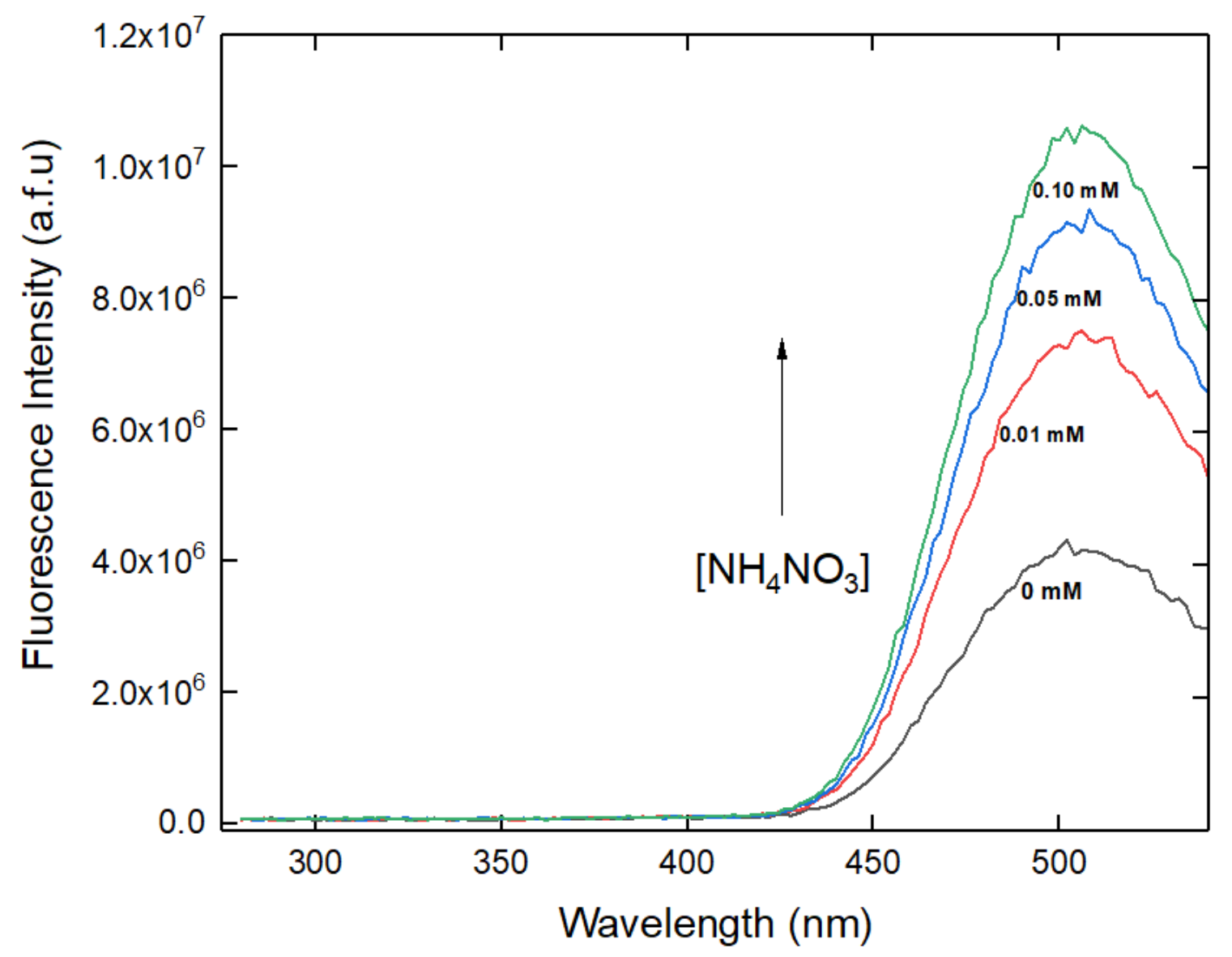

Figure 3.6. Fluorescence emission $\left(\lambda_{\text {exc }}=272 \mathrm{~nm}\right)$ of an organic phase $\left(\mathrm{CH}_{2} \mathrm{Cl}_{2}\right)$ containing $1 \& 2(0.05 \mathrm{mM})$ after extraction with $\mathrm{NH}_{4} \mathrm{NO}_{3} . \mathrm{NH}_{4} \mathrm{NO}_{3}$ concentrations are 0 $\mathrm{mM}$ (black), $0.01 \mathrm{mM}$ (red), $0.05 \mathrm{mM}$ (blue) and $0.1 \mathrm{mM}$ (green). 


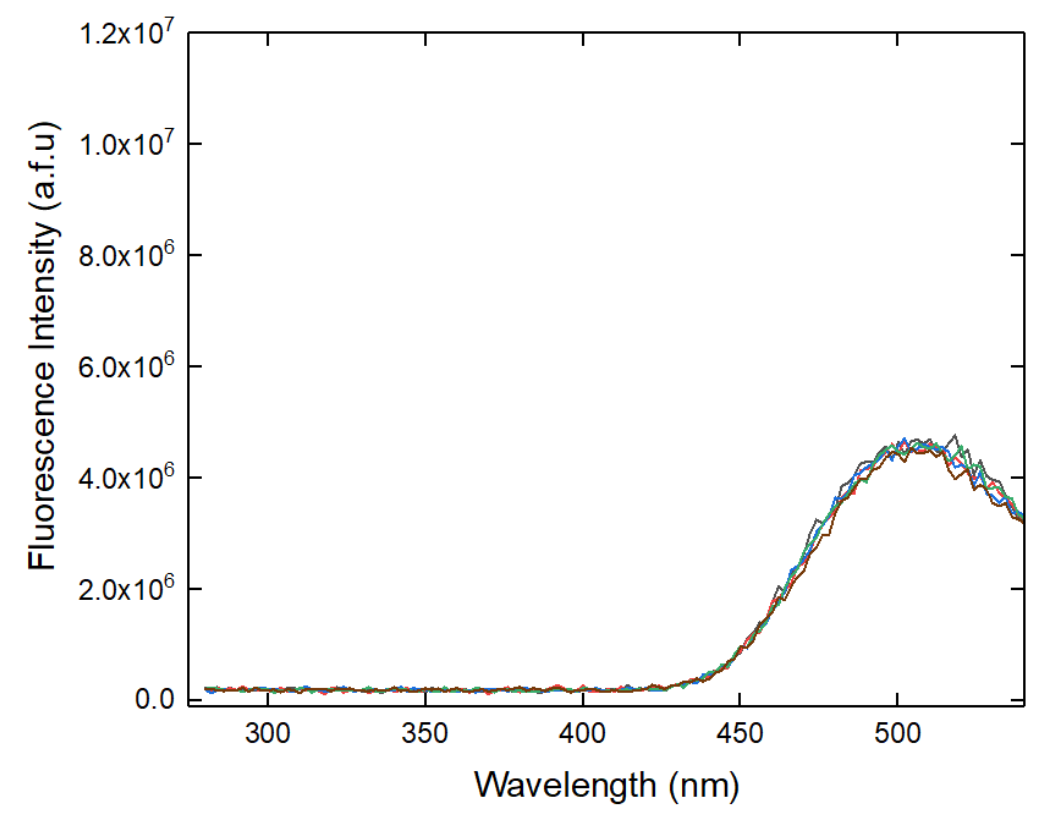

Figure 3.7. Fluorescence emission of $1 \& 2(0.05 \mathrm{mM})$ after extraction with $\mathrm{KNO}_{3}$ from water into $\mathrm{CH}_{2} \mathrm{Cl}_{2}$ following $272 \mathrm{~nm}$ excitation.

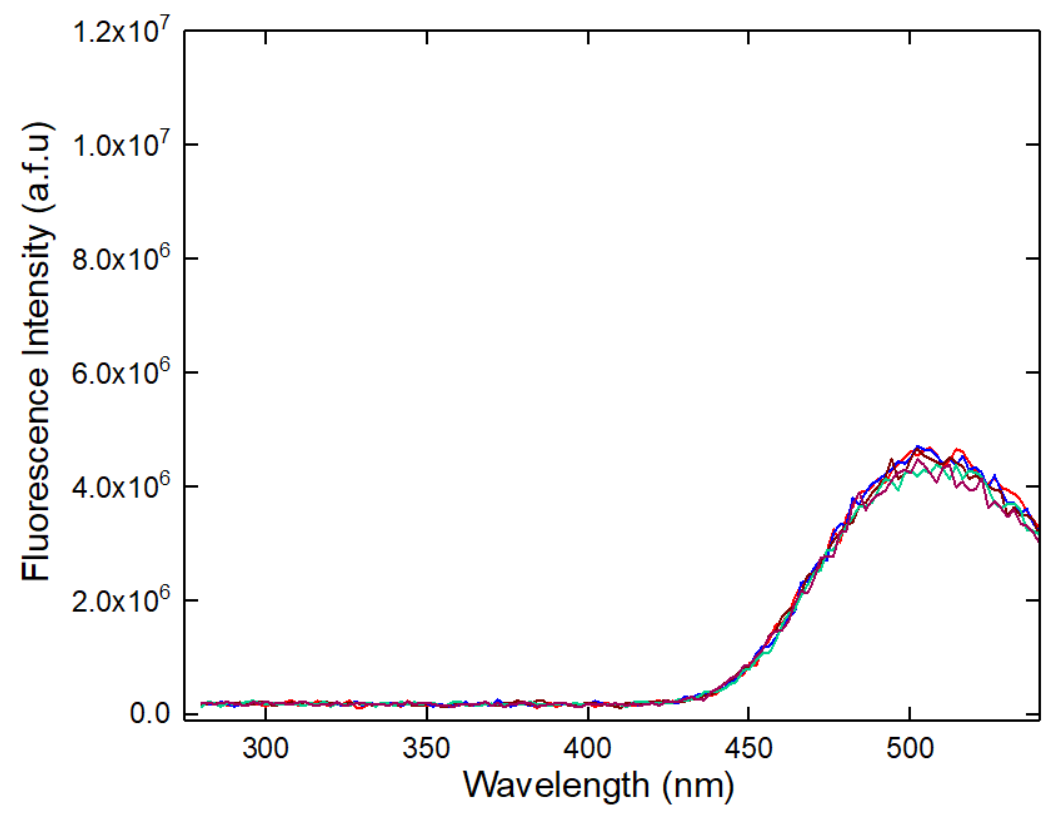

Figure 3.8. Fluorescence emission of $1 \& 2(0.05 \mathrm{mM})$ after extraction with $\mathrm{NaNO}_{3}$. Concentration range of $0 \mathrm{mM}-0.10 \mathrm{mM}$ in $\mathrm{CH}_{2} \mathrm{Cl}_{2}$ following $272 \mathrm{~nm}$ excitation. 


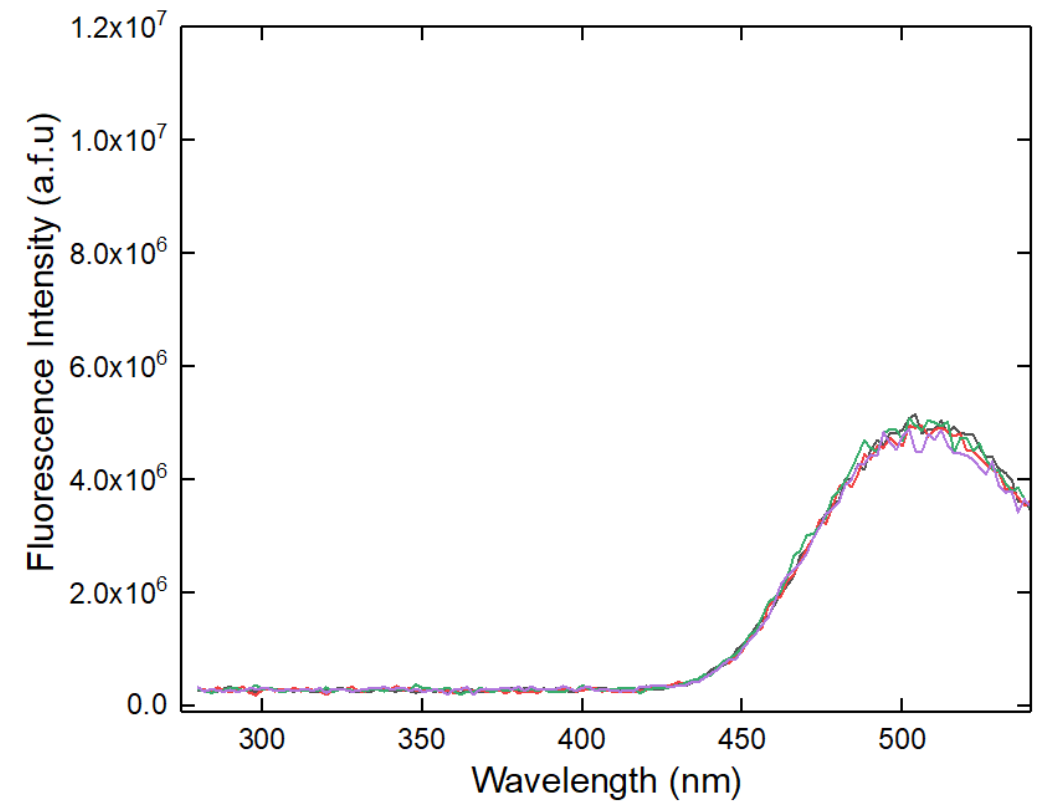

Figure 3.9. Fluorescence emission of $1 \& 2(0.05 \mathrm{mM})$ after extraction with $\mathrm{KCl}$ in $\mathrm{CH}_{2} \mathrm{Cl}_{2}$ following $272 \mathrm{~nm}$ excitation.

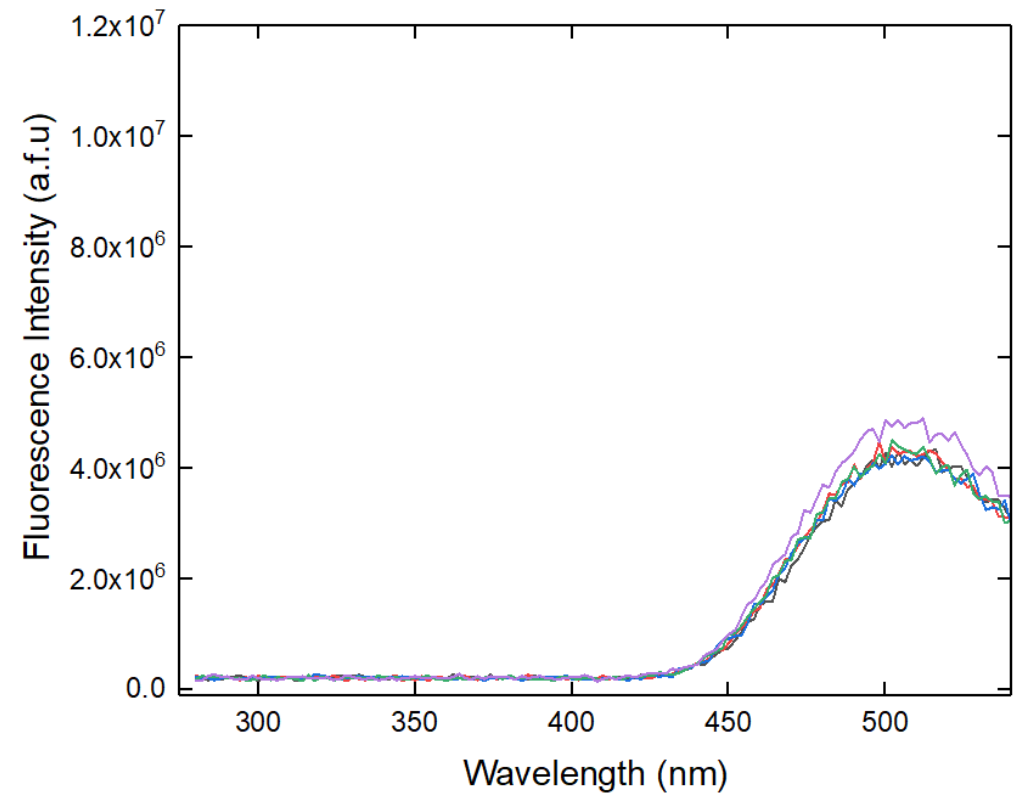

Figure 3.10. Fluorescence emission of $1 \& 2(0.05 \mathrm{mM})$ after extraction with $\mathrm{NaCl}$ in $\mathrm{CH}_{2} \mathrm{Cl}_{2}$ following $272 \mathrm{~nm}$ excitation. 
The remarkable FRET response selectivity for $\mathrm{NH}_{4} \mathrm{NO}_{3}$ vs. other alkali metal nitrate salts (Fig 3.11) and other halide salts (Fig. 3.12 and 3.13) demonstrates that our hypothesis of using FRET for selective dual-host extraction and sensing of $\mathrm{NH}_{4} \mathrm{NO}_{3}$ is a valid one. However, a point of concern is that FRET is not zero at zero concentration of added salts, thus implying that some association of $\mathbf{1}$ and $\mathbf{2}$ in the organic phase is taking place leading to FRET, even in the absence of the extracted salt. As receptor $\mathbf{2}$ has hydrogen bond donor $\mathrm{SO}_{2} \mathrm{NH}$ sites, and receptor $\mathbf{1}$ has pyrazole acceptor sites, this is a reasonable hypothesis.

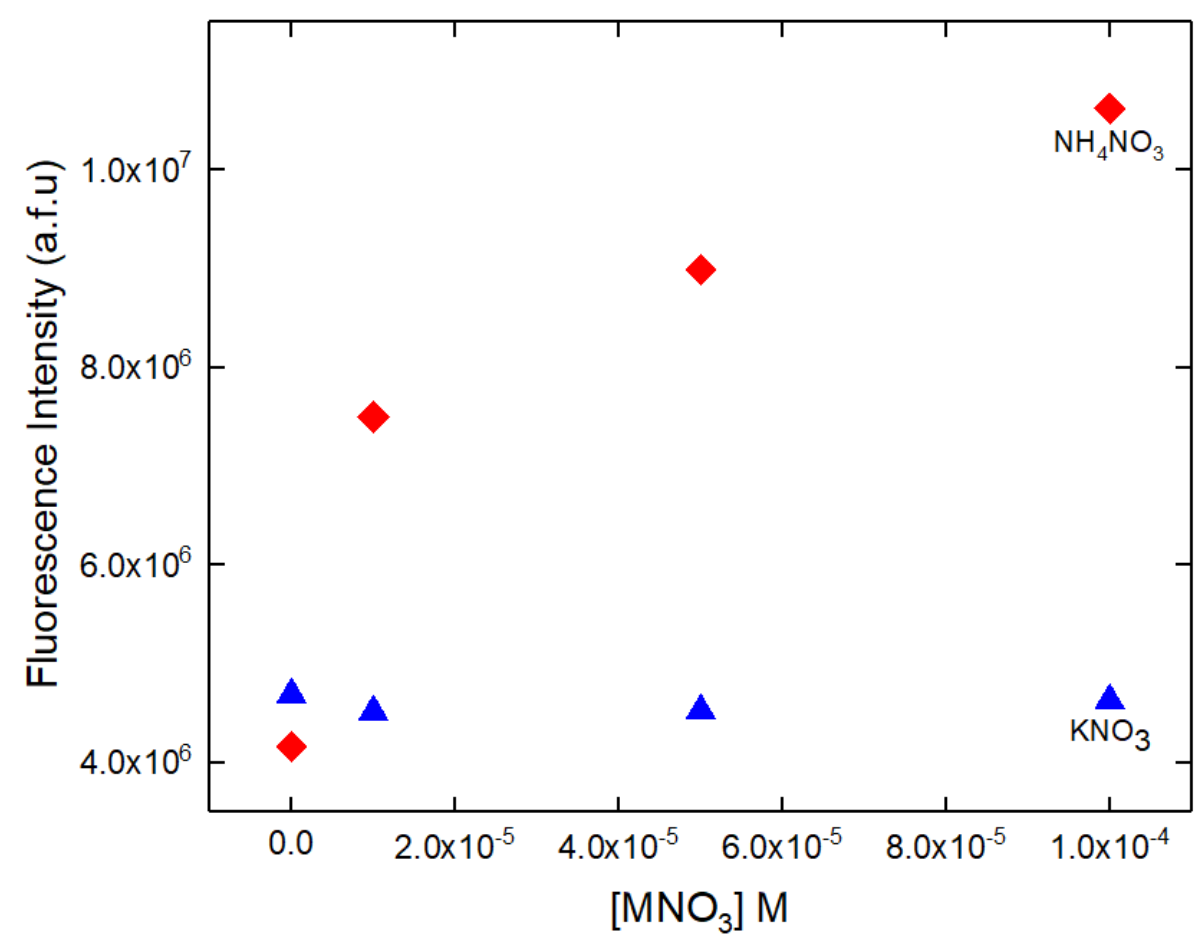

Figure 3.11. Fluorescence emission $\left(\lambda_{\text {exc }}=272 \mathrm{~nm}\right)$ of organic phases $\left(\mathrm{CH}_{2} \mathrm{Cl}_{2}\right)$ containing $1 \& 2(0.05 \mathrm{mM})$ after extraction with various concentrations of $\mathrm{MNO}_{3}\left(\mathrm{M}=\mathrm{NH}_{4}{ }^{+}, \mathrm{K}^{+}\right)$, showing selective FRET sensing for $\mathrm{NH}_{4} \mathrm{NO}_{3}$. 


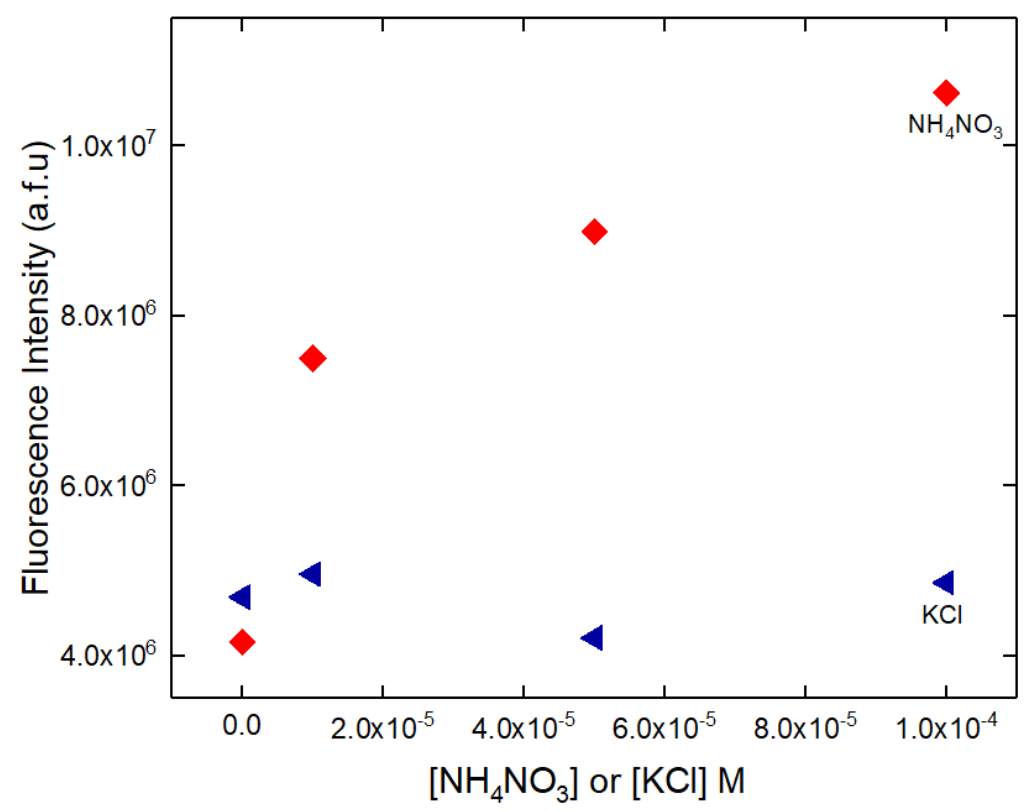

Figure 3.12. Fluorescence emission $\left(\lambda_{\text {exc }}=272 \mathrm{~nm}\right)$ of organic phases $\left(\mathrm{CH}_{2} \mathrm{Cl}_{2}\right)$ containing $1 \& 2(0.05 \mathrm{mM})$ after extraction with various concentrations of $\mathrm{NH}_{4} \mathrm{NO}_{3}$ and $\mathrm{KCl}$, showing selective FRET sensing for $\mathrm{NH}_{4} \mathrm{NO}_{3}$.

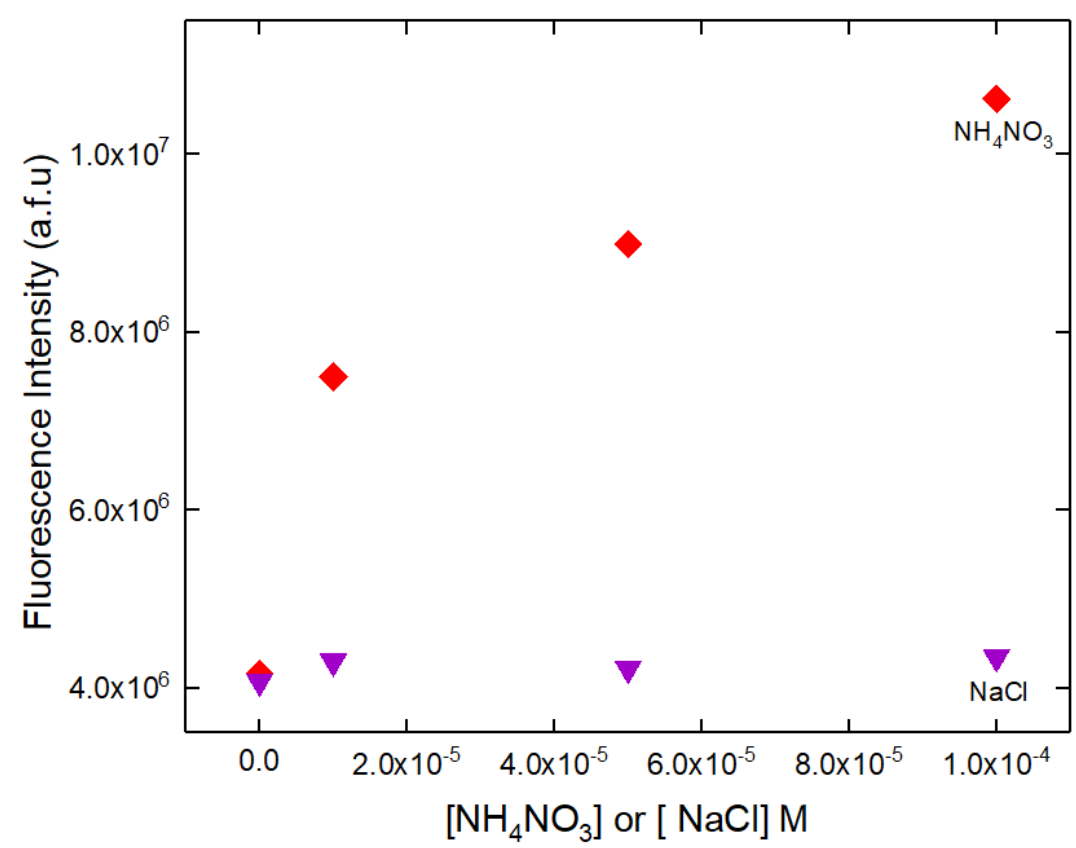

Figure 3.13. Fluorescence emission $\left(\lambda_{\mathrm{exc}}=272 \mathrm{~nm}\right)$ of organic phases $\left(\mathrm{CH}_{2} \mathrm{Cl}_{2}\right)$ containing $1 \& 2(0.05 \mathrm{mM})$ after extraction with various concentrations of $\mathrm{NH}_{4} \mathrm{NO}_{3}$ and $\mathrm{NaCl}$. 


\subsection{Conclusion}

In conclusion, we have performed ion pair extraction and ammonium nitrate sensing studies in organic solvents by fluorescence titration of mixed solutions of $\mathbf{1}$ and $\mathbf{2}$, in dichloromethane with aqueous solutions of $\mathrm{NH}_{4} \mathrm{NO}_{3}$. The results obtained from distribution experiments showed fluorescence enhancements upon contact with ammonium nitrate solutions. The control experiments with $\mathrm{KNO}_{3}, \mathrm{NaNO}_{3}, \mathrm{NaCl}$ and $\mathrm{KCl}$ gave negligible responses. $\mathrm{NH}_{4} \mathrm{NO}_{3}$ in aqueous media exists as hydrated ions. In organic media however ion pairing is maintained because of the low dielectric constant of the solvent and electrostatic attraction between cations and anions. Thus, intermolecular effects like FRET, give unique responses for the ion pair compared to the individual ions. We have now demonstrated a unique extraction-based ion pair sensing method using FRET for the first time. This novel ion-pair sensing paradigm paves the way for future sensitive and selective ion-pair sensing methods based on organophilic polymers or other materials of low polarity that can potentially be optimized for on-field detection use.

\subsection{Experimental}

\subsubsection{Materials and methods}

All materials (purchased from Aldrich Chemical Company or Acros Organics) were standard reagent grade and were used without further purification. Compound $\mathbf{1}$ was synthesized as previously reported. ${ }^{1} \mathrm{H}-\mathrm{NMR}$ spectra were recorded on a $400 \mathrm{MHz}$ Bruker NMR spectrometer and were referenced to the residual solvent resonance. All chemical shifts, $\delta$, are reported in ppm. 
3.5.2. Synthesis of $1,3,5$-Tris-(5-dimethylamino-1-naphthalenesulfonamido)methyl]2,4,6-triethylbenzene (2).

Triethylamine $(0.062 \mathrm{~mL}, \quad 0.465 \mathrm{mmol})$ was used to deprotonate $1,3,5-$ tris(aminomethyl)-2,4,6-triethylbenzene $(0.039 \mathrm{~g}, 0.155 \mathrm{mmol})$ in $2 \mathrm{~mL}$ of anhydrous 1,2DCE for 30 mins at room temperature. Dansyl chloride $(0.12 \mathrm{~g}, 0.46 \mathrm{mmol})$ dissolved in 6 $\mathrm{mL}$ of dichloroethane, was slowly added to the solution. The reaction mixture was left to stir under nitrogen for $4 \mathrm{~h}$. After the $4 \mathrm{~h}$ elapsed, ethyl acetate $(0.1 \mathrm{M}$ in water) was used to quench the reaction. The resulting solution was extracted with $\mathrm{CH}_{3} \mathrm{Cl}$. The organic layer was collected and dried with anhydrous sodium sulfate. This solution was concentrated and hexanes was added dropwise. The yellow precipitate that was formed was purified by column chromatography (90:10 $\left.\mathrm{CH}_{2} \mathrm{Cl}_{2} / \mathrm{EtOAc}\right)$ and dried under vacuum yielding 2 (0.12 g, 85\% yield): mp 218-220 ${ }^{\circ} \mathrm{C} ;{ }^{1} \mathrm{H} \mathrm{NMR}\left(\mathrm{CDCl}_{3}, 400 \mathrm{MHz}\right), 0.45(9 \mathrm{H}, \mathrm{t}, \mathrm{J}=7.4 \mathrm{~Hz}), 1.86$ $(6 \mathrm{H}, \mathrm{q}, \mathrm{J}=7.4 \mathrm{~Hz}), 2.93(18 \mathrm{H}, \mathrm{s}), 3.66(6 \mathrm{H}, \mathrm{d}, \mathrm{J}=5.2 \mathrm{~Hz}), 4.01(3 \mathrm{H}, \mathrm{s}), 7.56(6 \mathrm{H}, \mathrm{m}, \mathrm{J}=$ $3.9 \mathrm{~Hz}), 8.22(3 \mathrm{H}, \mathrm{d}, \mathrm{J}=8.6 \mathrm{~Hz}), 8.26(3 \mathrm{H}, \mathrm{d}, \mathrm{J}=7.2 \mathrm{~Hz}), 8.58(3 \mathrm{H}, \mathrm{d}, \mathrm{J}=8.2 \mathrm{~Hz}) ;{ }^{13} \mathrm{C}\left\{{ }^{1} \mathrm{H}\right\}$ $\operatorname{NMR}\left(\mathrm{CDCl}_{3}, 400 \mathrm{MHz}\right) \delta 15.6,21.8,40.8,45.4,115.4,118.4,123.0,128.5,129.6,129.7$, $129.8,130.2,130.7,133.4,144.3,152.0$.

\subsection{3 ${ }^{1} \mathrm{H}$ NMR Titrations of 2 with $(n-B u)_{4} \mathrm{~N}^{+} \mathrm{X}^{-}$.}

The association constants for the formation of anion-receptor complexes were determined by titration of solutions of $2\left(2.0 \times 10^{-3} \mathrm{M}\right)$ in $\mathrm{CDCl}_{3}$ (solution A) with $1 \times 10^{-1}$ M solutions of $(n-\mathrm{Bu})_{4} \mathrm{~N}^{+} \mathrm{NO}_{3}^{-}$prepared by dilution with solution $\mathrm{A}$, thus keeping a constant concentration of 2 (solution B). In a typical experiment solution A $(0.700 \mathrm{~mL})$ was placed in an NMR tube. Solution B was added in increments until a total of $1000 \mu \mathrm{l}$ was added. The chemical shift changes for the $\mathrm{N}-\mathrm{H}$ proton were monitored and the results 
were plotted and fitted to the 1:1 binding isotherm (Eq.1) using non-linear regression analysis.

$$
\left.\Delta \delta=\delta_{\text {obs }}-\delta_{2}=\left([\mathbf{R}]_{\mathrm{t}}+\left[\mathrm{X}^{-}\right]_{\mathrm{t}}+\mathrm{K}_{\mathrm{a}}^{-1}-\left(\left(\left([\mathbf{R}]_{\mathrm{t}}+\left[\mathrm{X}^{-}\right]_{\mathrm{t}}+\mathrm{K}_{\mathrm{a}}^{-1}\right)^{2}-4\left[\mathrm{X}^{-}\right]_{\mathrm{t}}[\mathbf{R}]_{\mathrm{t}}\right)^{1 / 2}\right)\right) \Delta \delta_{\max }\right)
$$

$/\left(2[\mathbf{R}]_{\mathrm{t}}\right) \quad($ Eq.1)

\subsubsection{Fluorescence Titrations of 2 with $(n-\mathrm{Bu})_{4} \mathrm{~N}^{+} \mathrm{NO}_{3}^{-}$}

Fluorescence emission was measured using an excitation wavelength of $352 \mathrm{~nm}$, a measurement increment of $0.5 \mathrm{~nm}$, and integration time of $0.1 \mathrm{~s}$, excitation slit width of 10 $\mathrm{nm}$, emission slit width of $5 \mathrm{~nm}$, and an emission wavelength of $505.5 \mathrm{~nm}$. Experiments were run using solutions of $2\left(1.0 \times 10^{-6} \mathrm{M}\right)$ in $\mathrm{CH}_{2} \mathrm{Cl}_{2}$ (solution A) which were titrated with solutions of $(n-\mathrm{Bu})_{4} \mathrm{~N}^{+} \mathrm{NO}_{3}^{-}\left(1.0 \times 10^{-3} \mathrm{M}\right)$ and $2\left(1.0 \times 10^{-6} \mathrm{M}\right)$ in $\mathrm{CH}_{2} \mathrm{Cl}_{2}$ (solution B). $2.0 \mathrm{~mL}$ of solution A was added to the fluorescence cuvette and solution B was added in increments until a total of $1000 \mu \mathrm{L}$ was added. The fluorescence intensity at $505.5 \mathrm{~nm}$ was monitored and recorded.

\subsubsection{Fluorescence titrations of solutions of $1 \& 2$ with $\mathrm{NH}_{4} \mathrm{PF}_{6}$ and $\left(n-\mathrm{Bu}_{4}\right)^{+} \mathrm{NO}_{3}^{-}$}

Fluorescence titration experiments were performed using receptors $\mathbf{1}$ and $\mathbf{2}$ in an organic solvent to extract $\mathrm{NH}_{4} \mathrm{NO}_{3}$ in an aqueous medium. Extraction experiments were performed using receptors 1 and 2 with $\mathrm{NH}_{4} \mathrm{PF}_{6}$ with $(n-\mathrm{Bu})_{4} \mathrm{~N}^{+} \mathrm{NO}_{3}{ }^{-}$in $\mathrm{CH}_{3} \mathrm{OH} / \mathrm{CH}_{2} \mathrm{Cl}_{2}$ (2:8). Experiments were run using solutions of 1 and $2\left(5 \times 10^{-5} \mathrm{M}\right)$ in $\mathrm{CH}_{3} \mathrm{OH} / \mathrm{CH}_{2} \mathrm{Cl}_{2}$ (2:8) (solution A) which were titrated with solutions of $\mathrm{NH}_{4}{ }^{+} \mathrm{PF}_{6}{ }^{-}$and $(n-\mathrm{Bu})_{4} \mathrm{~N}^{+} \mathrm{NO}_{3}{ }^{-}(5.0$ x $\left.10^{-3} \mathrm{M}\right)$ and 1 and $2\left(5.0 \times 10^{-5} \mathrm{M}\right)$ in $\mathrm{CH}_{3} \mathrm{OH} / \mathrm{CH}_{2} \mathrm{Cl}_{2}(2: 8)$ (solution B). $2.0 \mathrm{~mL}$ of solution A was added to the fluorescence cuvette and solution B was added in increments until a total of $1000 \mu \mathrm{L}$ was added. The fluorescence intensity at $505.5 \mathrm{~nm}$ was monitored. 


\subsubsection{Extraction Titrations and Controls.}

Extraction experiments were performed using receptors $\mathbf{1}$ and $\mathbf{2}$ in an organic solvent to extract $\mathrm{NH}_{4} \mathrm{NO}_{3}$ in an aqueous medium. For all steps, aqueous phase to organic phase volume ratios were 1:1. All aqueous phases were prepared in deionized water, and all organic phases used spectroscopic grade $\mathrm{CH}_{2} \mathrm{Cl}_{2}$ as the solvent. $\mathrm{NH}_{4} \mathrm{NO}_{3}$ extractions were performed in initial aqueous concentration range of $1.0 \times 10^{-5} \mathrm{M}$ to $1.0 \times 10^{-4} \mathrm{M}$. The organic phases contained $5.0 \times 10^{-5} \mathrm{M}$ of $\mathbf{1}$ and $\mathbf{2}$ in $\mathrm{CH}_{2} \mathrm{Cl}_{2}$. In a typical experiment, 5.0 $\mathrm{mL}$ of both aqueous and organic phases were used. Extraction took place over $4 \mathrm{~h}$, with the organic layer being separated from the aqueous layer thereafter. The fluorescence of the organic layer was recorded. The same procedure was repeated for $\mathrm{NaNO}_{3}, \mathrm{KNO}_{3}, \mathrm{NH}_{4} \mathrm{Cl}$, $\mathrm{NaCl}$, and $\mathrm{KCl}$.

\subsection{References}

(1) Cafeo, G.; Gattuso, G.; Kohnke, F. H.; Notti, A.; Occhipinti, S.; Pappalardo, S.; Parisi, M. F. Remarkable Boosting of the Binding of Ion-Paired Organic Salts by Binary Host Systems. Angew. Chemie - Int. Ed. 2002, 41, 2122-2126.

(2) McConnell, A. J.; Beer, P. D. Heteroditopic Receptors for Ion-Pair Recognition. Angew. Chemie - Int. Ed. 2012, 51, 5052-5061.

(3) Beer, P. D.; Bernhardt, P. V. A ferrocene functionalised macrocyclic receptor for cations and anions.. J. Chem. Soc., Dalt. Trans. 2001, 1428-1431.

(4) Beer, P. D.; Drew, M. G. B.; Knubley, R. J.; Ogden, M. I. Synthesis and coordination chemistry of a novel bis(benzo crown ether) substituted calix[4]arene that can simultaneously complex cations and anions. J. Chem. Soc., Dalt. Trans. 1995, 3117-3123.

(5) Cooper, J. B.; Drew, M. G. B.; Beer, P. D. Heteroditopic rhenium(I) and ruthenium(II) bipyridyl calix[4]arene receptors for binding cation-anion ion pairs. J. Chem. Soc., Dalt. Trans. 2001, 392-401.

(6) Cooper, J. B.; Drew, M. G. B.; Beer, P. D. Alkali metal cation cooperative anion recognition by heteroditopic bis(calix[4]arene) rhenium(I) bipyridyl and ferrocene receptor molecules. J. Chem. Soc., Dalt. Trans. 2000, 2721-2728. 
(7) Rudkevich, D. M.; Mercer-Chalmers, J. D.; Verboom, W.; Ungaro, R.; de Jong, F.; Reinhoudt, D. N. Bifunctional Recognition: Simultaneous Transport of Cations and Anions through a Supported Liquid Membrane. J. Am. Chem. Soc. 1995, 117, 61246125.

(8) Reetz, M. T.; Niemeyer, C. M.; Harms, K. Crown Ethers with a Lewis Acidic Center: A New Class of Heterotopic Host Molecules. Angew. Chemie Int. Ed. English 1991, 30, 1472-1474.

(9) D. Beer, P.; K. Hopkins, P.; D. McKinney, J. Cooperative Halide, Perrhenate AnionSodium Cation Binding and Pertechnetate Extraction and Transport by a Novel Tripodal Tris(amido Benzo-15-Crown-5) Ligand. Chem. Commun. 1999, 12531254.

(10) Kavallieratos, K.; Danby, A.; Berkel, G. J. Van; Kelly, M. a; Sachleben, R. a; Moyer, B. a; Bowman-james, K. Enhancement of CsNO 3 Extraction in 1,2Dichloroethane by Tris ( 2-Aminoethyl ) Amine Triamide Derivatives via a DualHost Strategy. 2008, 72, 5258-5264.

(11) Kavallieratos, K.; Sachleben, R. A.; Van Berkel, G. J.; Moyer, B. A. Novel DualHost Approach in Ion Pair Extraction: A Simple Tripodal Nitrate Host Facilitates CsNO3 Transfer to 1,2-Dichloroethane by a Large Crown Ether. Chem. Commun. 2000, 187-188.

(12) Ravikumar, I.; Saha, S.; Ghosh, P. Dual-Host Approach for Liquid-Liquid Extraction of Potassium Fluoride/chloride via Formation of an Integrated 1-D Polymeric Complex. Chem. Commun. 2011, 47, 4721-4723.

(13) Chutia, R.; Dey, S. K.; Das, G. A Supramolecular Dual-Host Based Ion-Pair Induced Formation of 1D Coordination Polymer. CrystEngComm 2013, 15, 9641-9647.

(14) Chin, J.; Walsdorff, C.; Stranix, B.; Oh, J.; Chung, H. J.; Park, S. M.; Kim, K. A Rational Approach to Selective Recognition of $\mathrm{NH}_{4}{ }^{+}$over $\mathrm{K}^{+}$. Angew. Chemie - Int. Ed. 1999, 38, 2756-2759.

(15) (a) Ahn, K. H.; Ku, H. Y.; Kim, Y.; Kim, S. G.; Kim, Y. K.; Son, H. S.; Ku, J. K. Fluorescence Sensing of Ammonium and Organoammonium Ions with Tripodal Oxazoline Receptors. Org. Lett. 2003, 5, 1419-1422. (b) Currie, R. Spectroscopic, Electrochemical and Mass Spectrometric Investigation of Anion Binding by Tripodal Molecular Receptors. Florida International University, 2005.

(16) Ahn, K. H.; Kim, S. G.; Jung, J. Y.; Kim, K. H.; Kim, J.; Chin, J.; Kim, K. Selective Recognition of $\mathrm{NH}_{4}{ }^{+}$over $\mathrm{K}^{+}$with Tripodal Oxazoline Receptors. Chem. Lett. 2000, 170-171.

(17) Rueda-zubiaurre, A.; Herrero-garcía, N. Rational Design of a Nonbasic Molecular Receptor for Selective $\mathrm{NH}_{4}{ }^{+} / \mathrm{K}^{+}$Complexation in the Gas Phase. Chem. Eur. J. 2012, 1, 16884-16889.

(18) Jon, S. Y.; Kim, J.; Kim, M.; Park, S.; Jeon, W. S.; Heo, J.; Kim, K. A Rationally 
Designed $\mathrm{NH}_{4}{ }^{+}$Receptor Based on Cation- $\pi$ Interaction and Hydrogen Bonding . Angew. Chemie 2001, 113, 2174-2177.

(19) Kim; Ahn. Novel Artificial Receptors for Alkylammonium Ions with Remarkable Selectivity and Affinity. Chemistry 2000, 6 , 3399-3403.

(20) Jon, S. Y.; Kim, J.; Kim, M.; Park, S.; Jeon, W. S.; Heo, J.; Kim, K. A Rationally Designed $\mathrm{NH}_{4}{ }^{+}$Receptor Based on Cation- $\pi$ Interaction and Hydrogen Bonding . Angew. Chemie Int. Ed. 2001, 40, 2116-2119.

(21) KaleidaGraph, Version 3.0.2. Synergy Software (PCS Inc.), Reading, PA 19606. Developed by Abelbeck Software Inc.

(22) Kilway, K. V; Siegel, J. S. Control of Functional Group Proximity and Direction by Conformational Networks: Synthesis and Stereodynamics of Persubstituted Arenes. Tetrahedron 2001, 57, 3615-3627. 


\section{CHAPTER IV}

Tripodal pyrazole ligands and analogs for selective lanthanide sensing

Tosin M. Jonah, Logesh Mathivathanan, Gabriel Flores, Raphael G. Raptis, Konstantinos Kavallieratos*

Department of Chemistry \& Biochemistry, Florida International University, Miami, FL, United States. 


\subsection{Abstract}

Actinide removal from alkaline high-level waste (HLW) stored in underground tanks at the Hanford \& Savannah River sites is of great concern. Furthermore, selectively separating actinides (An) from lanthanides (Ln) in used nuclear fuel presents an important challenge in closing the nuclear fuel cycle. Tripodal ligand frameworks based on 1,3,5trisubstituted-2,4,6 triethylbenzene provide a highly pre-organized cavity for binding of cations, such as $\mathrm{NH}_{4}{ }^{+}, \mathrm{Ln}(\mathrm{III})$ and An(III). Previous work by our group and others have shown the potential of such frameworks for binding $\mathrm{NH}_{4}{ }^{+}$(Chapter 2$)$. Herein, we compare three tris-pyrazole frameworks for $\operatorname{Ln}(\mathrm{III})$ extraction and sensing, with the further goal of eventually developing selective $\mathrm{An}(\mathrm{III}) / \mathrm{Ln}(\mathrm{III})$ separation processes and combined Cs(I) and An(III) separation and extraction from High-Level Waste. The proposed ligands are based on the 1,3,5-tris(pyrazolyl)-2,4,6-triethyl benzene frameworks. Binding of Ln(III) in organic solvents by these ligands is confirmed by fluorescence, and NMR titration experiments. Chemical shift changes for all proton resonances were observed, indicating cation binding. Fluorescence titrations of $1 \times 10^{-4} \mathrm{M}$ of 1,3,5-tris(3,5-dimethylpyrazolyl)2,4,6-triethyl benzene with $\mathrm{La}\left(\mathrm{NO}_{3}\right)_{3} \cdot 6 \mathrm{H}_{2} \mathrm{O}$ also showed evidence of binding. The binding

affinity was determined by ${ }^{1} \mathrm{H}-\mathrm{NMR}$ titrations with $\mathrm{La}^{3+}$ in acetone-d $\mathrm{d}_{6}$. Non-linear regression analysis of the binding isotherms gave a 1-1 complexation ratio, with an association constant $\mathrm{K}_{\mathrm{a}}$ of $155 \mathrm{M}^{-1}$ for $\mathrm{La}^{3+}$.

\subsection{Introduction}

The processing and removal of high heat emitters from nuclear waste streams continuously poses a serious concern. These streams usually contain long-lived radiotoxic minor actinides and fission products. ${ }^{1-3}$ The radiotoxicity and high heat generator in these 
nuclear waste streams are the actinides. ${ }^{3-9}$ There is a continuous effort in generating ligands that can separate these high heat emitters from the nuclear fuel waste. Selectively separating minor actinides (An) from lanthanides $(\mathrm{Ln})$ in used nuclear fuel presents an important challenge in closing the nuclear fuel cycle. This is because of the chemical similarities between the actinides and lanthanides in their ionic radii and identical oxidation states. There has been continuous effort in looking for ligands to successfully separate the trivalent actinides from lanthanides, and fission products. Gullu et a ${ }^{10}$ synthesized macrocyclic receptors based on the lactam ionophore to investigate the complexation pattern of this class of ligands towards Ln(III). The observed changes in the emission and absorption spectra of these compounds upon contact with $\operatorname{Ln}(\mathrm{III})$ were attributed to intramolecular energy transfer process. A fluorescent sensor bearing a diazostilbenzene and benzo-15-crown ether moiety capable of detecting lanthanide ions with high sensitivity and resolution has also been reported. ${ }^{11}$ Detectable fluorescence signals were observed when equimolar concentrations of the ligands and Ln(III) were used in THF. A cyclenbased fluorescent ligand capable of detecting micromolar concentrations of $\mathrm{Y}^{3+}$ and $\mathrm{La}^{3+}$ ions in water was reported by Aoki et al. ${ }^{12}$ Preorganized tripodal ligands ${ }^{13-15}$ have recently been explored for $\operatorname{Ln}(\mathrm{III})$ sensing: The tripodal fluoroionophore reported by Das et al. ${ }^{13}$ shows selective fluorescence enhancement with addition of Ce(III) in dry THF. The tris(2-benzimidazolylmethyl) amine showed strong intramolecular $\pi$ - $\pi$ interactions and gave 2:1 ligand to metal ratios upon complexation with $\operatorname{Ln}(\mathrm{IIII}){ }^{14}$

Herein, we report the complexation behavior of $\mathrm{Ln}(\mathrm{III})\left(\mathrm{La}^{3+}, \mathrm{Nd}^{3+}, \mathrm{Lu}^{3+}, \mathrm{Ce}^{3+}, \mathrm{Eu}^{3+}\right.$ and $\mathrm{Sm}^{3+}$ ) with three pyrazole receptors, based on the 1,3,5-triethylbenzene framework. We have undertaken a systematic study of the effects of pyrazole substitution on the Ln(III) 
binding properties by NMR and fluorescence spectroscopy, with remarkably similar conclusions on the effects of solvation and ion pairing, as in our study described earlier on $\mathrm{NH}_{4}{ }^{+}$(Chapter 2). The binding affinity of these ligands towards $\mathrm{Ln}(\mathrm{III})$ were determined by ${ }^{1} \mathrm{H}-\mathrm{NMR}$ titrations in acetone- $\mathrm{d}_{6}$ as well as from analysis of the fluorescence spectra.

\subsection{Results and discussion}

The three receptors used in this work were prepared by modifications of previously reported methods. ${ }^{16} \mathrm{NaOH}$ was used to deprotonate the corresponding pyrazole in DMF. The resulting solution was then let to react with tris-1,3,5-(bromomethyl)-2,4,6triethylbenzene at $70{ }^{\circ} \mathrm{C}$ for $48 \mathrm{~h}$. The fluorescence emission intensity of the free receptors is shown in Figures 4.1 and 4.2. The emission intensities in the presence of $\operatorname{Ln}(\mathrm{III})\left(\mathrm{La}^{3+}\right.$, $\mathrm{Nd}^{3+}, \mathrm{Lu}^{3+}, \mathrm{Ce}^{3+}, \mathrm{Eu}^{3+}$ and $\mathrm{Sm}^{3+}$ ) are shown in Figures 4.3-4.5.

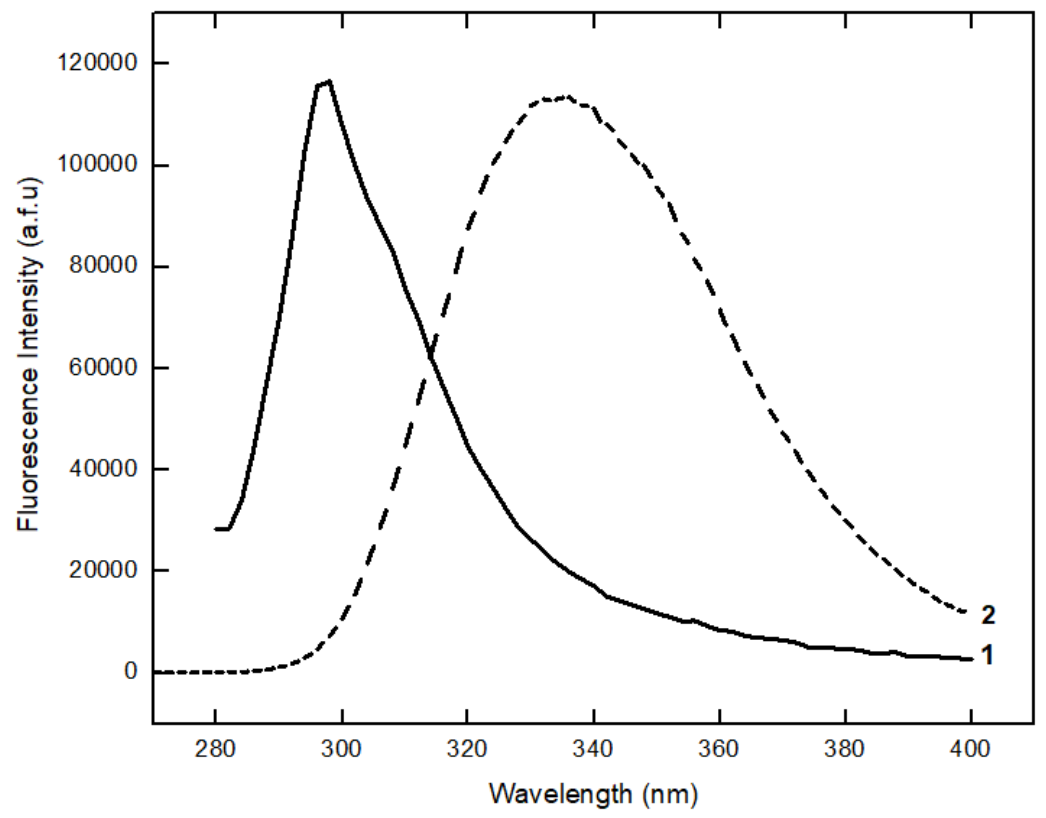

Figure 4.1 Fluorescence emission for receptor $1\left(\lambda_{\text {exc }}=272 \mathrm{~nm}\right)$ and $2\left(\lambda_{\text {exc }}=262 \mathrm{~nm}\right)$ in $\mathrm{CH}_{3} \mathrm{CN} / \mathrm{CH}_{2} \mathrm{Cl}_{2}$ (1:1). 


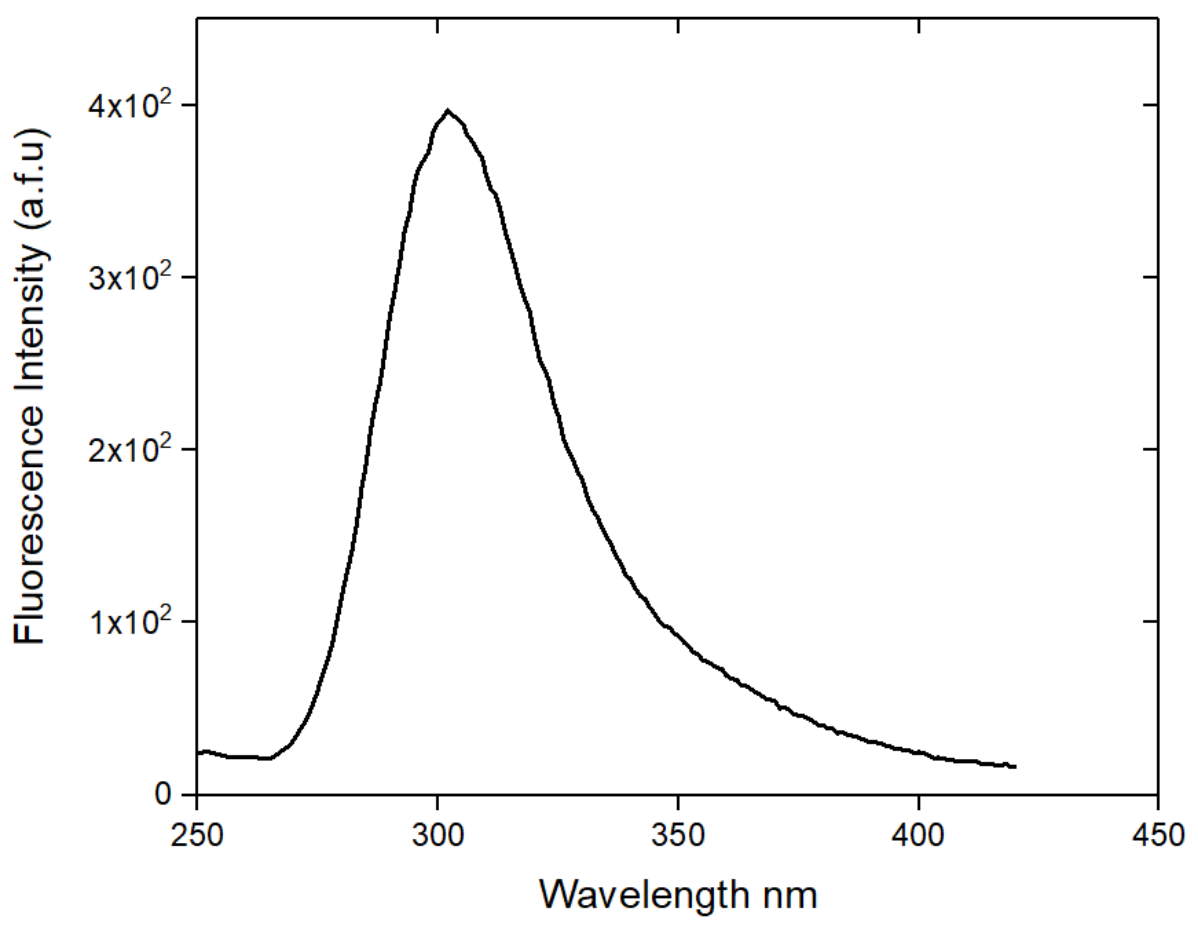

Figure 4.2 Fluorescence emission of receptor 3 in $\mathrm{CH}_{3} \mathrm{CN}$ at $\lambda_{\mathrm{exc}}=230 \mathrm{~nm}$

Fluorescence titrations of the three receptors with $\operatorname{Ln}(\mathrm{III})$ salts were carried out at constant receptor concentration $\left(1.0 \times 10^{-4} \mathrm{M}\right)$ in $\mathrm{CH}_{3} \mathrm{CN}\left(\lambda_{\mathrm{exc}}=272 \mathrm{~nm} ; \lambda_{\mathrm{em}}=298 \mathrm{~nm}\right.$ for 1, and $\lambda_{\text {exc. }}=262 \mathrm{~nm} ; \lambda_{\mathrm{em}}=335 \mathrm{~nm}$ for $\mathbf{2}$ and $\lambda_{\mathrm{exc}}=230 \mathrm{~nm} ; \lambda_{\mathrm{em}}=304 \mathrm{~nm}$ for $\left.\mathbf{3}\right)$. In the case of receptor $\mathbf{1}$, the addition of $\mathrm{Sm}^{3+}, \mathrm{Eu}^{3+} \mathrm{La}^{3+}, \mathrm{Nd}^{3+}, \mathrm{Lu}^{3+}$ to solution of $\mathbf{1}$, resulted in enhancement in intensity at the maximum emission at $298 \mathrm{~nm}$, with the receptor reaching saturation at 1:1 ratio (Figures 4.3-4.8). When $\mathrm{Ce}^{3+}$ was added to a solution of $\mathbf{1}$, two phenomena were observed: An increase in fluorescence followed by a sharp quenching, a trend different from the other Ln (III). The results from the titration curves indicate that pyrazoles are indeed a family that can be used for $\operatorname{Ln}(\mathrm{III})$ sensing. When the pyrazole substitution pattern changes from dimethyl in $\mathbf{1}$ to diphenyl in $\mathbf{2}$, the results show that the diphenyl receptor 2 does not appreciably bind to $\operatorname{Ln}(\mathrm{III})$. The fluorescence intensity 
changes observed with the addition of $\mathrm{Sm}^{3+} \mathrm{La}^{3+}, \mathrm{Nd}^{3+}, \mathrm{Lu}^{3+}$ to a solution of 2 in acetonitrile showed only small changes and no particular trend (Figure 4.3-4.8) except for $\mathrm{Ce}^{3+}$ that showed slight, but consistent quenching. For the unsubstituted pyrazole 3, addition of lanthanide salts in acetonitrile, led to consistent fluorescence quenching without any considerable shift in the emission maximum, indicating $\operatorname{Ln}(\mathrm{III})$ binding.
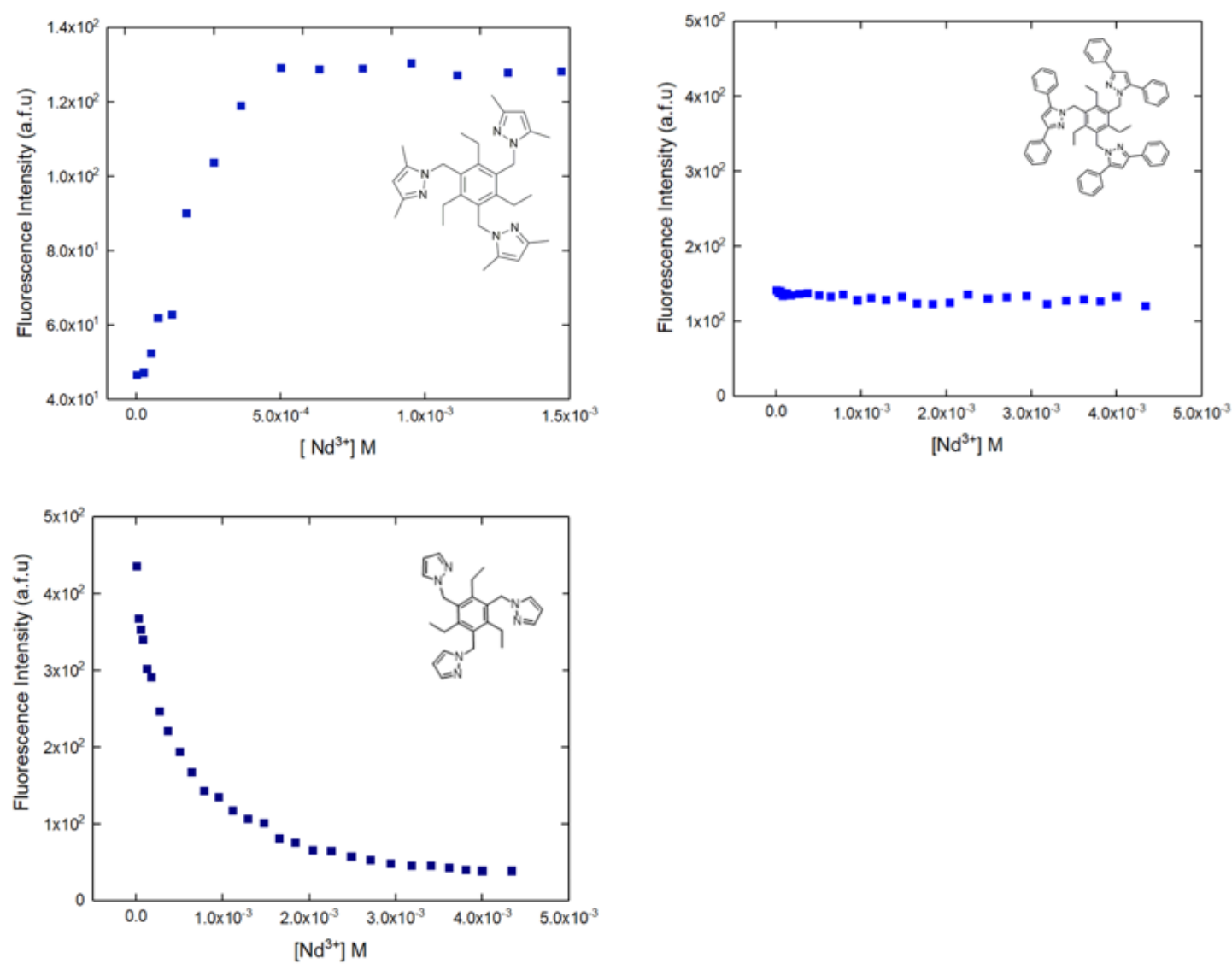

Figure 4.3. Fluorescence titrations of $\mathbf{1}, 2$ and $\mathbf{3}\left(1.0 \times 10^{-4} \mathrm{M}\right)$ with $\mathrm{Nd}\left(\mathrm{NO}_{3}\right)_{3}$ in $\mathrm{CH}_{3} \mathrm{CN}$. 

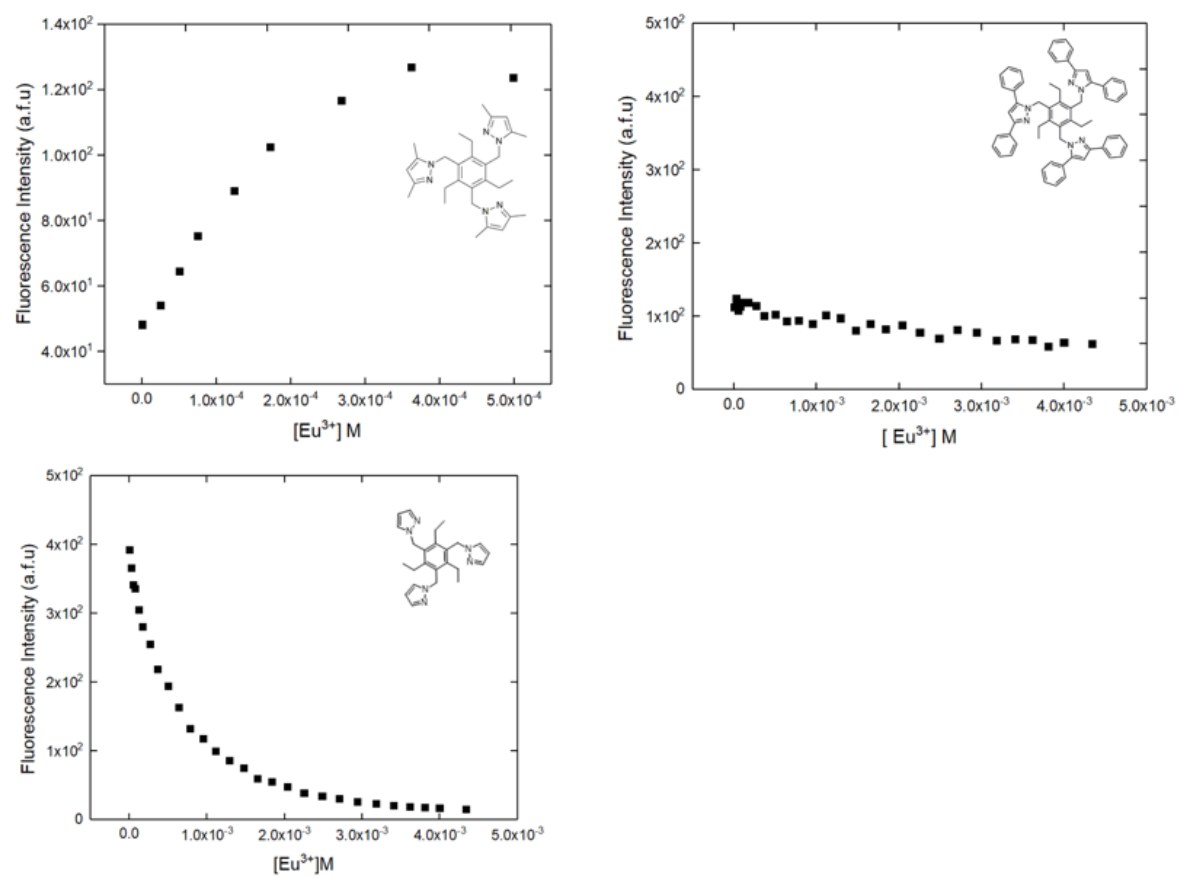

Figure 4.4. Fluorescence titrations of 1,2 and $3\left(1.0 \times 10^{-4} \mathrm{M}\right)$ with $\mathrm{Eu}\left(\mathrm{NO}_{3}\right)_{3}$ in $\mathrm{CH}_{3} \mathrm{CN}$.
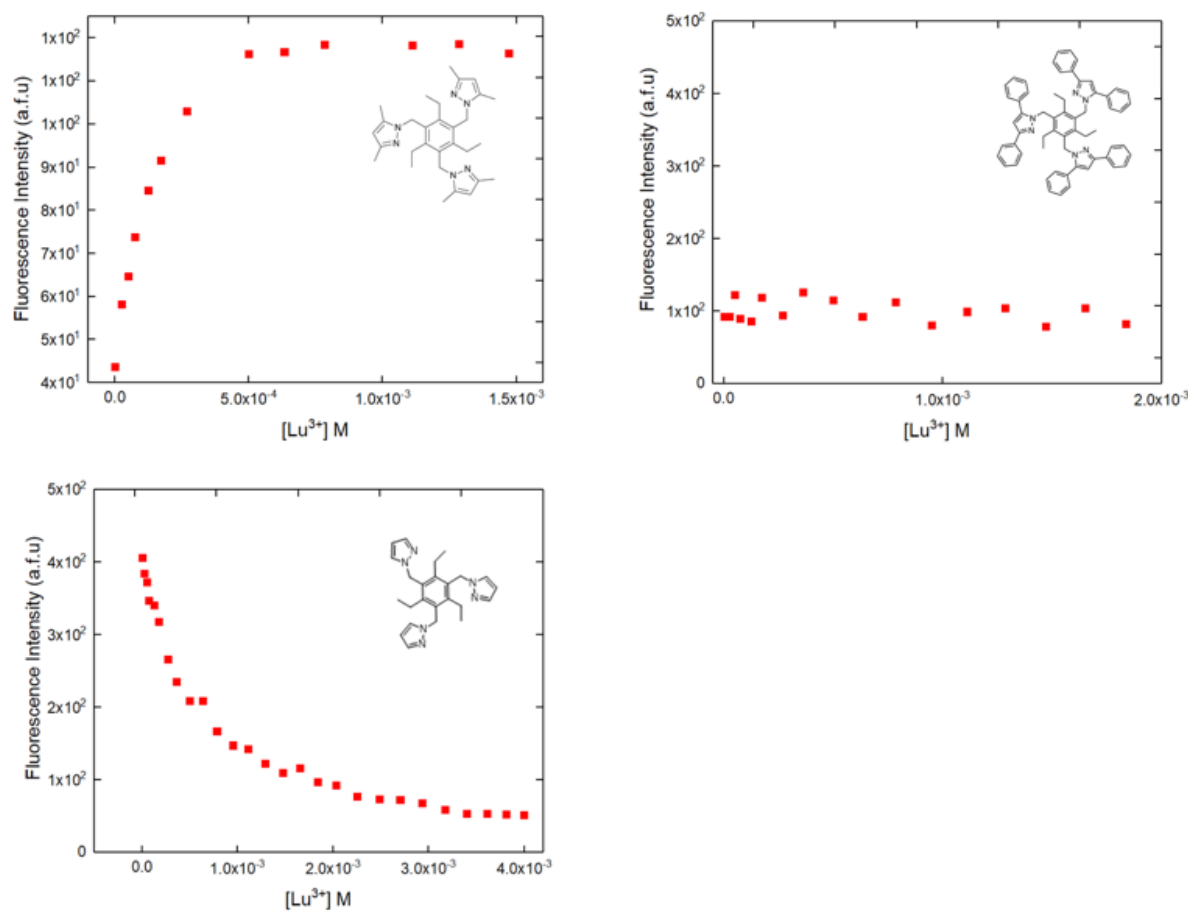

Figure 4.5. Fluorescence titrations of $\mathbf{1 , 2}$ and $3\left(1.0 \times 10^{-4} \mathrm{M}\right)$ with $\mathrm{Lu}\left(\mathrm{NO}_{3}\right)_{3}$ in $\mathrm{CH}_{3} \mathrm{CN}$. 

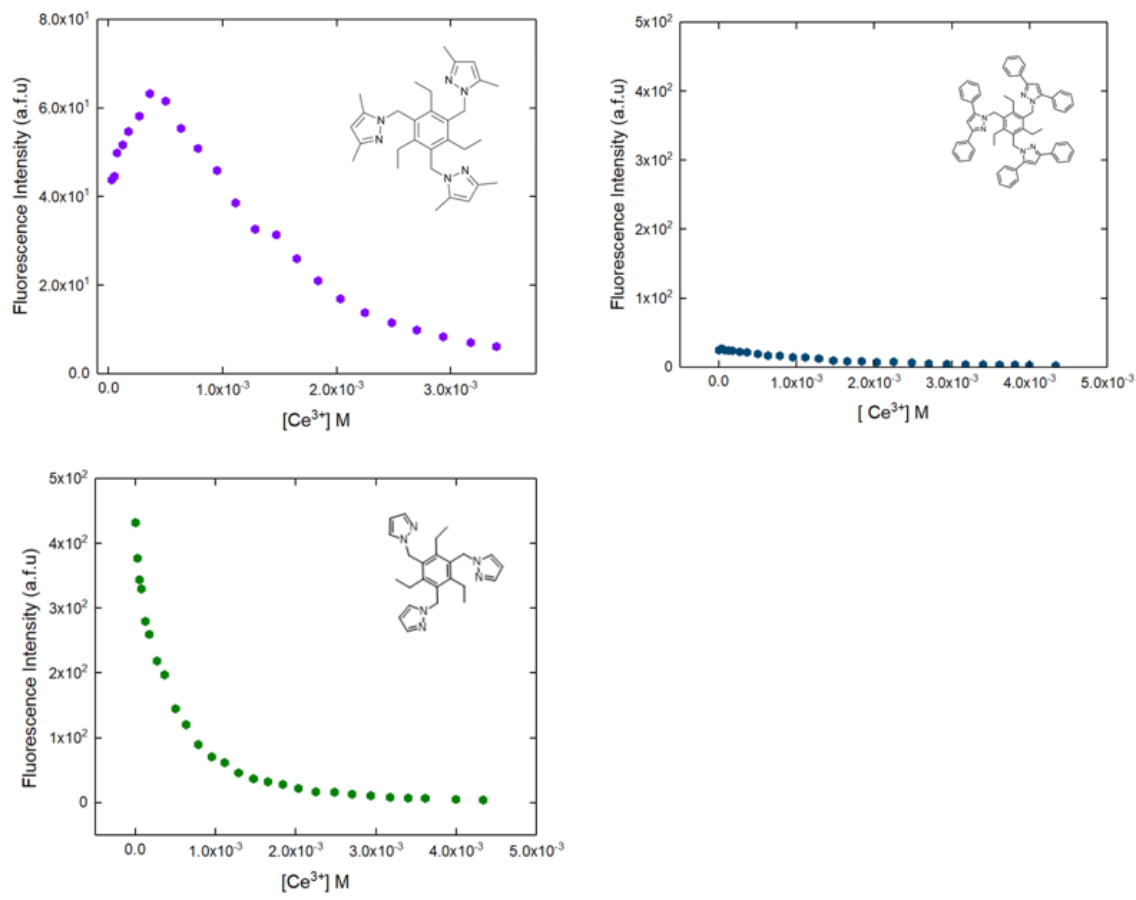

Figure 4.6. Fluorescence titrations of 1,2 and $3\left(1.0 \times 10^{-4} \mathrm{M}\right)$ with $\mathrm{Ce}\left(\mathrm{NO}_{3}\right)_{3}$ in $\mathrm{CH}_{3} \mathrm{CN}$.
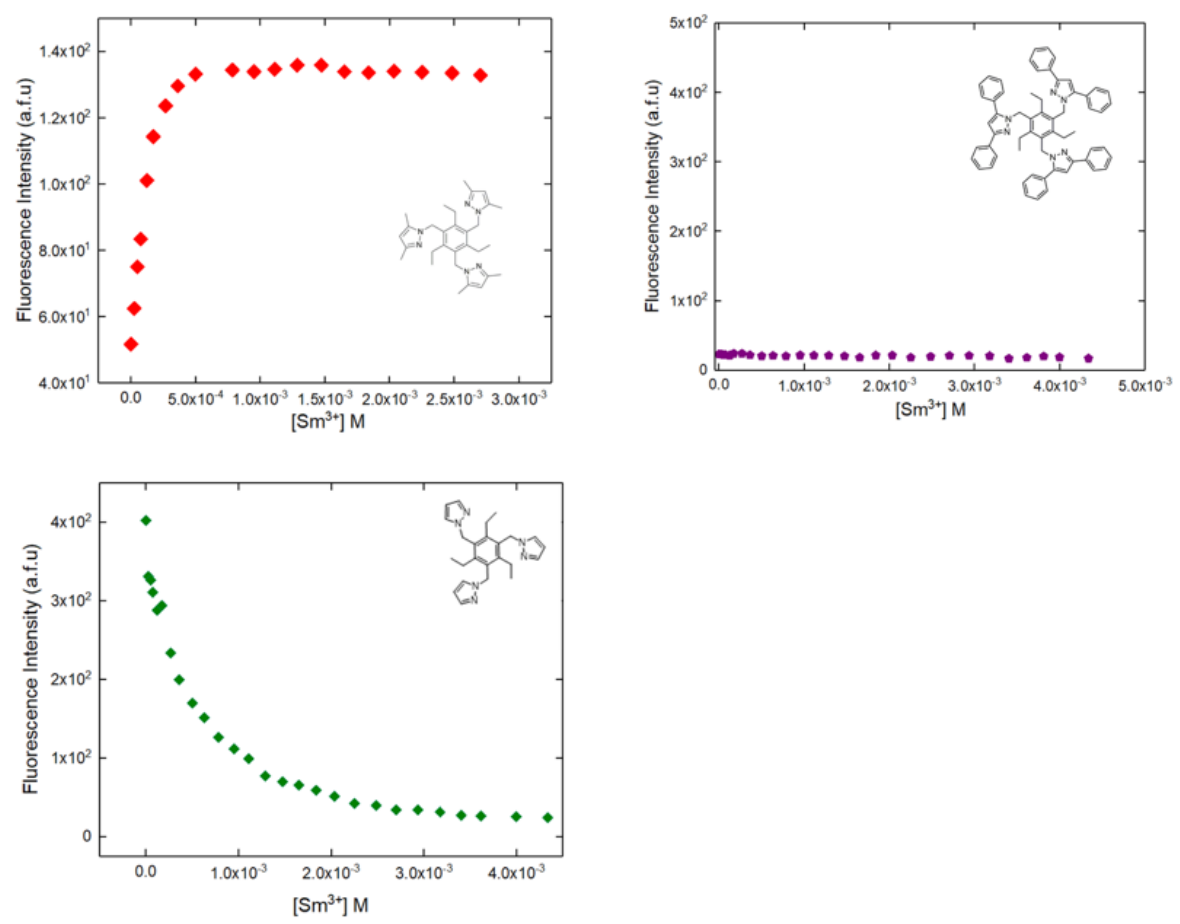

Figure 4.7. Fluorescence titrations of $\mathbf{1}, 2$ and $3\left(1.0 \times 10^{-4} \mathrm{M}\right)$ with $\mathrm{Sm}\left(\mathrm{NO}_{3}\right)_{3}$ in $\mathrm{CH}_{3} \mathrm{CN}$. 

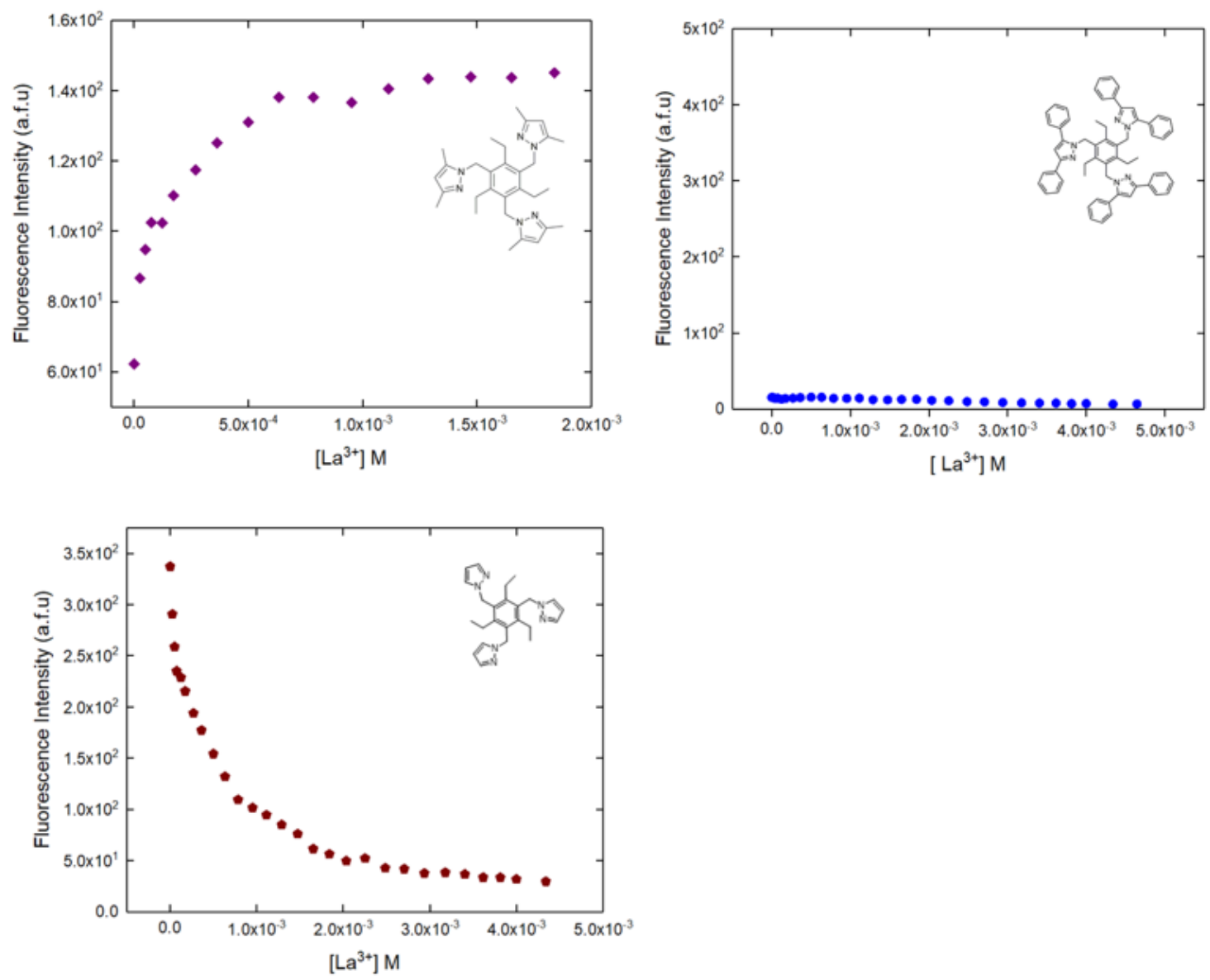

Figure 4.8. Fluorescence titrations of 1,2 and $3\left(1.0 \times 10^{-4} \mathrm{M}\right)$ with $\mathrm{La}\left(\mathrm{NO}_{3}\right)_{3}$ in $\mathrm{CH}_{3} \mathrm{CN}$.

The observed fluorescence enhancements were fitted to the Benesi-Hildebrand equation:

$$
\mathrm{I}_{0} / \mathrm{I}-\mathrm{I}_{0}=\mathrm{b} /(\mathrm{a}-\mathrm{b})[1 / \mathrm{K}[\mathrm{M}]+1]
$$

where $\mathrm{I}_{0}$ is the fluorescence intensity of the sensor in the absence of guest $\operatorname{Ln}(\mathrm{III})$; I is the fluorescence intensity of the sensor in the presence of guest; $[\mathrm{M}]$ is the concentration of the substrates; and $\mathrm{K}$ is the association constant between the sensor and the substrates. In the equation, $a$ and $b$ are constants. The value of $b /(a-b)$ is the intercept of the plot of $I_{0} /\left(I-I_{0}\right)$ 
against the inverse of the concentration term, $\mathrm{M}^{-1}$. $\mathrm{I}_{0}$ and I are found out experimentally. The association constant of $\mathbf{1}$ with $\mathrm{La}^{3+}$ was $2.5 \times 10^{4} \mathrm{M}^{-1}$, and for $\mathbf{1}$ with $\mathrm{Sm}^{3+}$ was 2020 $\mathrm{M}^{-1}$ (Figure $4.9 \& 4.10$ ) as derived from the Benesi-Hildebrand equation.

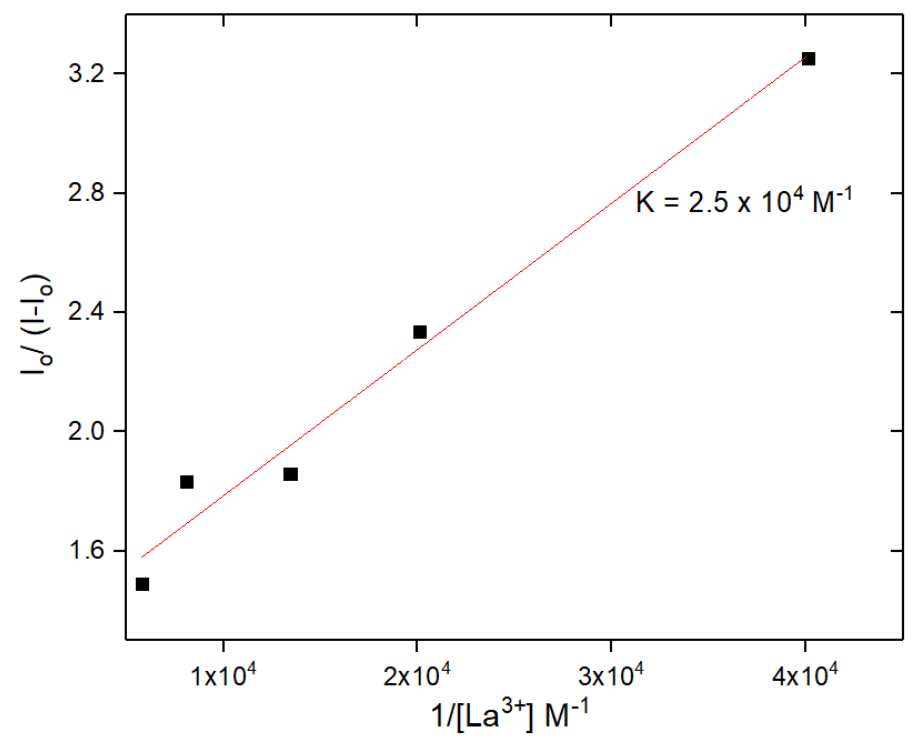

Figure 4.9. Benesi-Hildebrand plot of receptor 1 in acetonitrile in the presence of $\mathrm{La}^{3+}$.

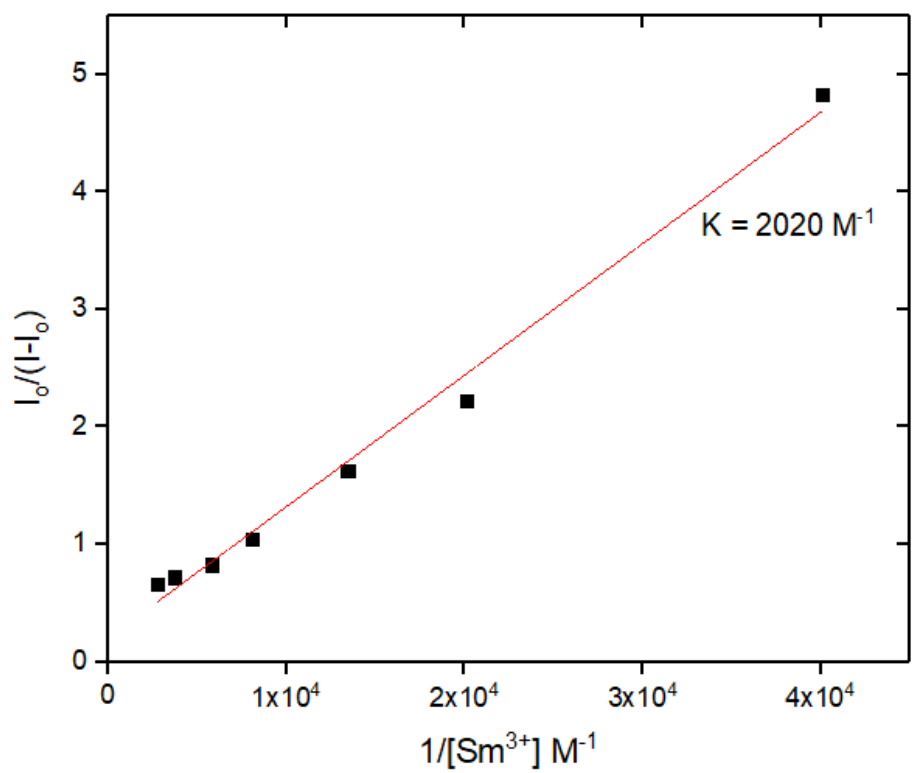

Figure 4.10. Benesi-Hildebrand plot of receptor 1 in acetonitrile in the presence of $\mathrm{Sm}^{3+}$. 
The observed fluorescence quenching upon titration of unsubstituted pyrazole receptor 3 with $\operatorname{Ln}(\mathrm{III})$ was fitted to the Stern-Volmer equation (eq. 4.2) where, the quencher concentration is $[\mathrm{Q}]$, the Stern-Volmer constant is $\mathrm{K}_{\mathrm{sv}}, \mathrm{I}_{\mathrm{o}}$ is the measured fluorescence intensity without quencher present, and I is the measured fluorescence intensity with $[Q]$ present.

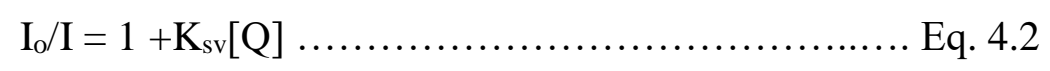

At lower concentrations of $\mathrm{Ln}(\mathrm{III})$, a plot of $\mathrm{I}_{0} / \mathrm{I}$ vs [ $\left.\mathrm{Ln}\right]$ is linear, and the Stern-Volmer constant $\left(\mathrm{K}_{\mathrm{sv}}\right)$ for fluorescence quenching is $1900 \mathrm{M}^{-1}$ for $\mathrm{Sm}^{3+}, 4000 \mathrm{M}^{-1}$ for $\mathrm{Ce}^{3+}, 2400$ $\mathrm{M}^{-1}$ for $\mathrm{La}^{3+}, 2600 \mathrm{M}^{-1}$, for $\mathrm{Nd}^{3+}$ and $1500 \mathrm{M}^{-1}$ for $\mathrm{Lu}^{3+}$. The Stern-Volmer constant $\mathrm{K}_{\mathrm{sv}}$ showed that 3 binds stronger to $\mathrm{Ce}^{3+}$ compared to the other $\mathrm{Ln}(\mathrm{III})$ ions studied. The SternVolmer plot for 3 with $\mathrm{Sm}^{3+}, \mathrm{Lu}^{3+}$, and $\mathrm{Nd}^{3+}$ are shown in Figures 4.11-4.13. From the fluorescence titration results, we can conclude that $\mathbf{1}$ and $\mathbf{3}$ can be utilized as sensors for $\operatorname{Ln}(\mathrm{III})$ ions while $\mathbf{2}$ does not show any appreciable trend in fluorescence to conclude that it binds $\operatorname{Ln}(\mathrm{III})$. These results are consistent with the conclusions on the effects of pyrazole substitution to solvation and ion pairing, from our $\mathrm{NH}_{4}{ }^{+}$complexation study (Chapter 2). 


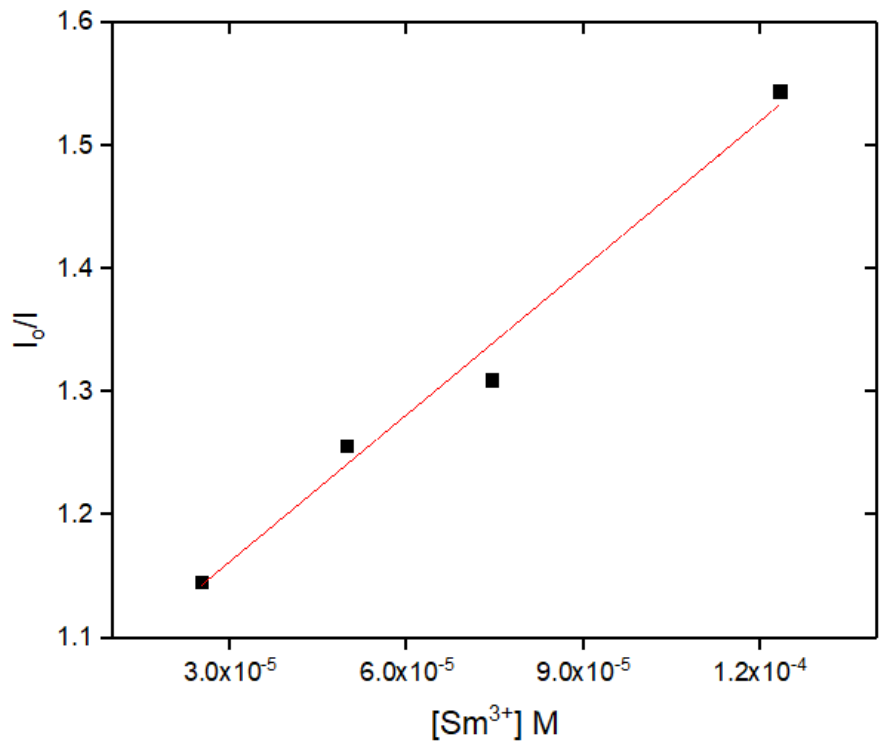

Figure 4.11. Stern-Volmer plot of $3\left(1.0 \times 10^{-4} \mathrm{M}\right)$ with low concentration of $\mathrm{Sm}\left(\mathrm{NO}_{3}\right)_{3}$ in $\mathrm{CH}_{3} \mathrm{CN}$.

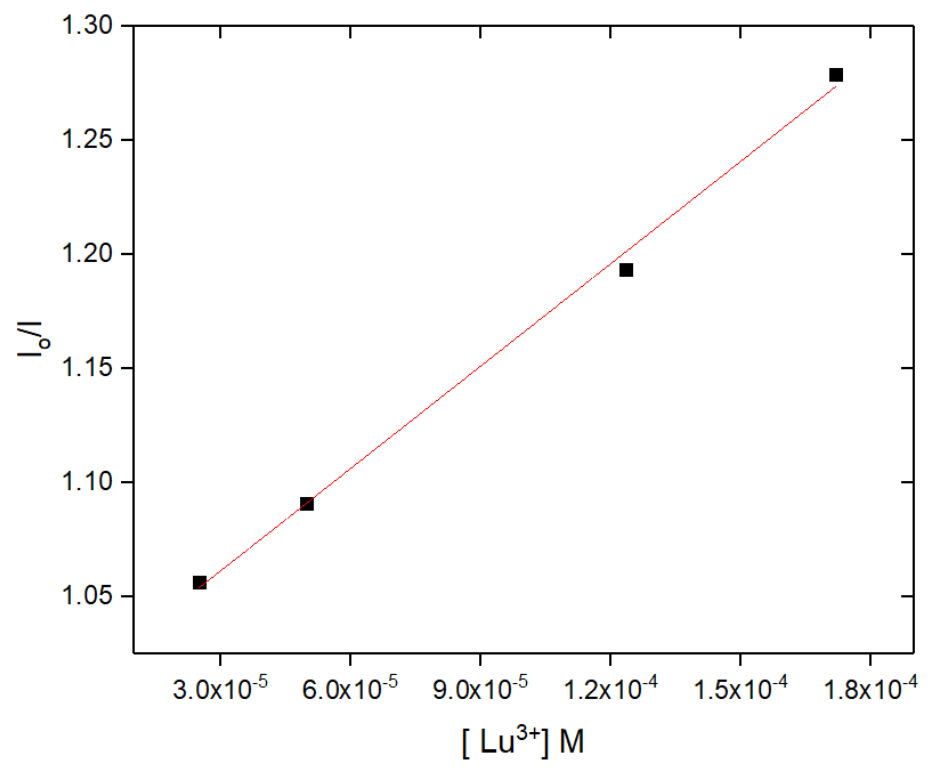

Figure 4.12. Stern- Volmer plot of $3\left(1.0 \times 10^{-4} \mathrm{M}\right)$ with low concentration of $\mathrm{Lu}\left(\mathrm{NO}_{3}\right)_{3}$ in $\mathrm{CH}_{3} \mathrm{CN}$. 


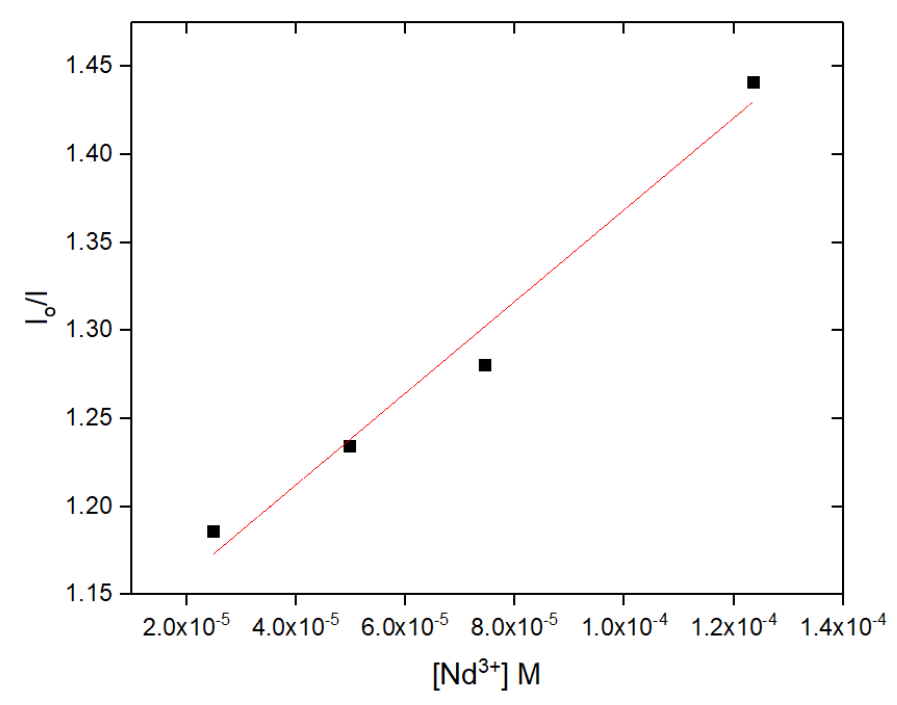

Figure 4.13. Stern-Volmer plot of $3\left(1.0 \times 10^{-4} \mathrm{M}\right)$ with low concentration of $\mathrm{Nd}\left(\mathrm{NO}_{3}\right)_{3}$ in $\mathrm{CH}_{3} \mathrm{CN}$.

The cation binding properties of $\mathbf{1 - 3}$ with $\mathrm{La}\left(\mathrm{NO}_{3}\right)_{3}$ were determined in acetone- $\mathrm{d}_{6}$ for 1 and 2, and $\mathrm{CD}_{3} \mathrm{CN}-\mathrm{d}_{3}$ for 3 by ${ }^{1} \mathrm{H}-\mathrm{NMR}$ titrations with $\mathrm{M}^{+} \mathrm{NO}_{3}{ }^{-}\left(\mathrm{M}^{+}=\mathrm{La}^{3+}\right)$. The association constants for the formation of a 1:1 complex, $\mathrm{K}_{\mathrm{a}}$, were determined by nonlinear regression analysis using the 1:1 binding isotherm (Eq. 4.3):

$\left.\Delta \delta=\delta_{\text {obs }}-\delta_{2}=\left([\mathbf{R}]_{\mathrm{t}}+\left[\mathrm{X}^{-}\right]_{\mathrm{t}}+\mathrm{K}_{\mathrm{a}}^{-1}-\left(\left(\left([\mathbf{R}]_{\mathrm{t}}+\left[\mathrm{X}^{-}\right]_{\mathrm{t}}+\mathrm{K}_{\mathrm{a}}^{-1}\right)^{2}-4\left[\mathrm{X}^{-}\right]_{\mathrm{t}}[\mathbf{R}]_{\mathrm{t}}\right)^{1 / 2}\right)\right) \Delta \delta_{\max }\right) /\left(2[\mathbf{R}]_{\mathrm{t}}\right) \quad$ eqn. 4.3

For 1, downfield shifts of all the pyrazolyl proton resonances were observed upon cation addition. The $\mathrm{CH}_{2}$ protons of the ethyl showed slight upfield shifts, instead. Nonlinear regression analysis of the binding isotherms obtained from the downfield chemical shift changes for the $\mathrm{C}-\mathrm{H}$, resonances gave a $1: 1$ association constant $\mathrm{K}_{\mathrm{a}}$ of $155 \mathrm{M}^{-1}$ for the formation of 1· $\left[\mathrm{La}^{3+}\right]$ (Figure 4.14). 


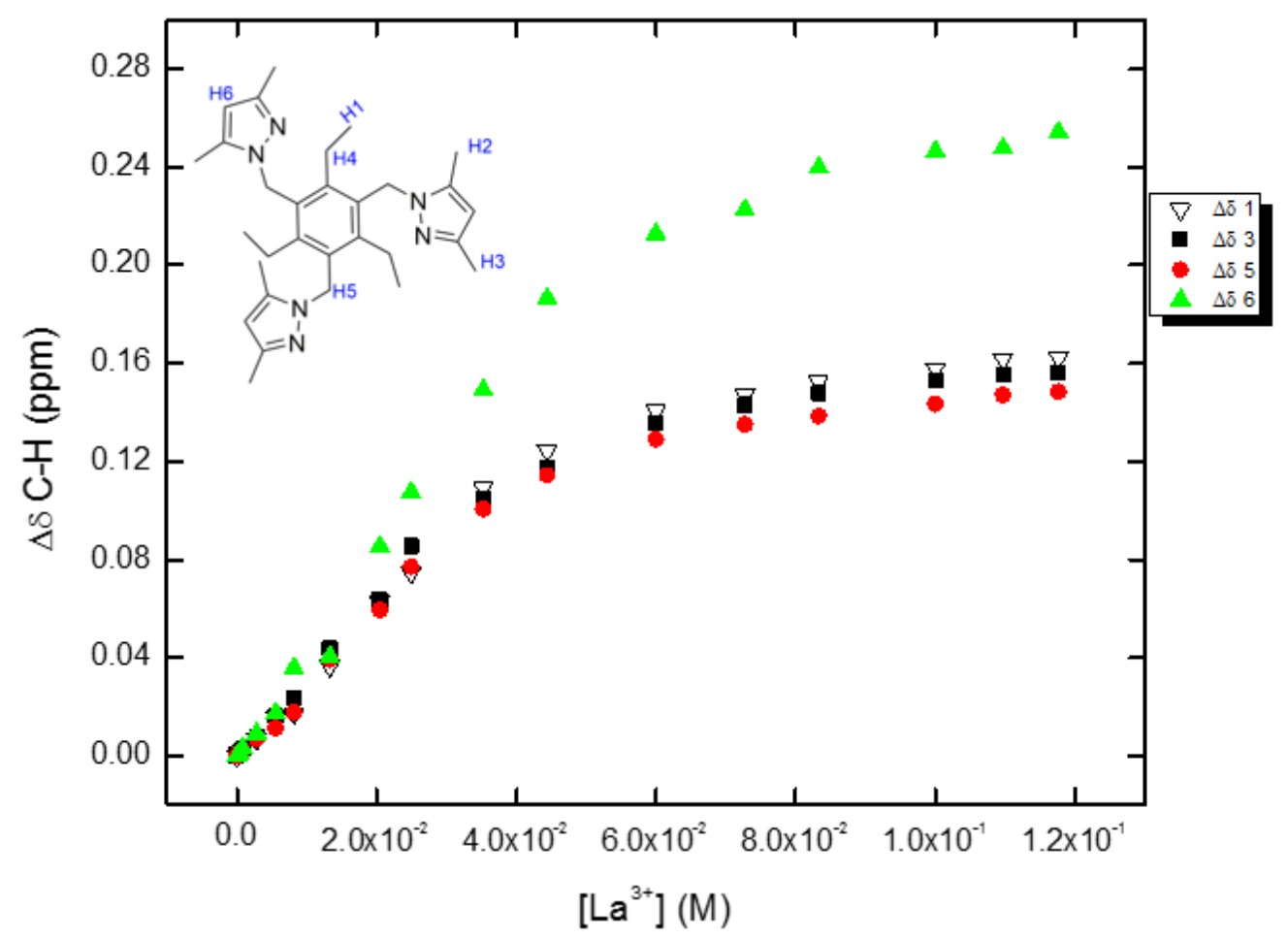

Figure 4.14. ${ }^{1} \mathrm{H}-\mathrm{NMR}$ titration plot of 1 with $\mathrm{La}\left(\mathrm{NO}_{3}\right)_{3} \cdot 6 \mathrm{H}_{2} \mathrm{O}$ in acetone- $\mathrm{d}_{6}$. The concentration of 1 was kept constant at $2 \mathrm{mM}$.

In the case of the diphenyl substituted pyrazole 2 , downfield shift of the proton was observed when titrated with $\mathrm{La}\left(\mathrm{NO}_{3}\right)_{3} \cdot 6 \mathrm{H}_{2} \mathrm{O}$. However, the spectrum did not show appreciable shifts large enough to determine the association constant $\mathrm{K}_{\mathrm{a}}$. For $\mathbf{3}$, the $\mathrm{CH}_{2}$ protons of the ethyl group shift upfield upon addition of $\mathrm{La}\left(\mathrm{NO}_{3}\right)_{3} \cdot 6 \mathrm{H}_{2} \mathrm{O}$ while two of the protons $\left(\mathrm{H}_{5}\right.$ and $\left.\mathrm{H}_{6}\right)$ on the pyrazolyl ring both moved downfield and the third $\left(\mathrm{H}_{4}\right)$ moved upfield (Figure 4.15). 


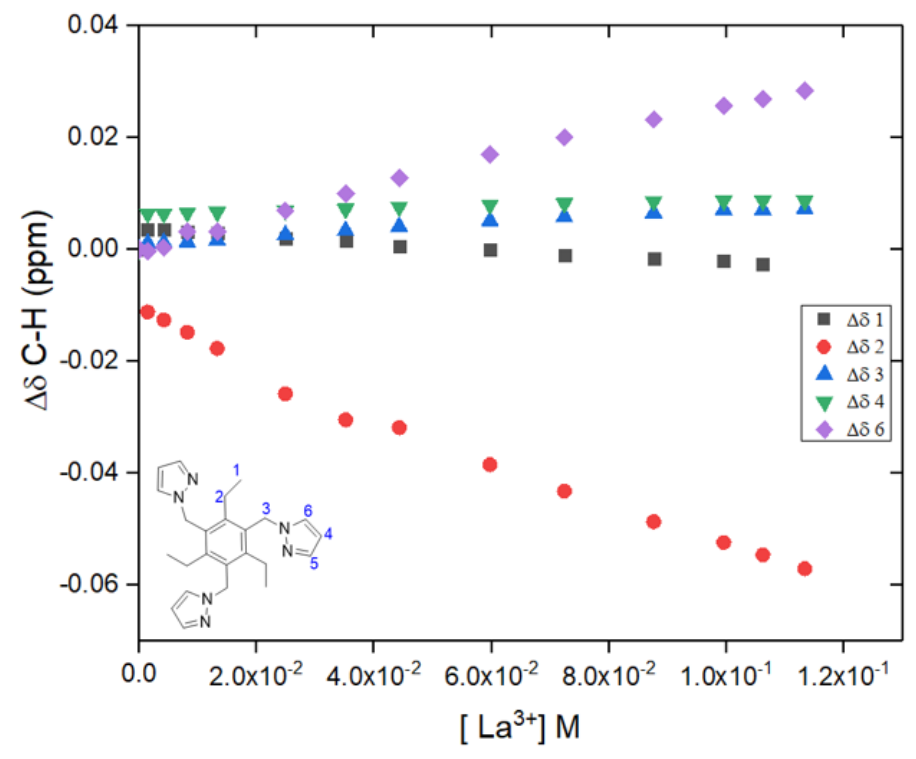

Figure 4.15. ${ }^{1} \mathrm{H}-\mathrm{NMR}$ titration plot of 3 with $\mathrm{La}\left(\mathrm{NO}_{3}\right)_{3} \cdot 6 \mathrm{H}_{2} \mathrm{O}$ in acetonitrile- $\mathrm{d}_{3}$. The concentration of $\mathbf{3}$ was kept constant at $2 \mathrm{mM}$.

\subsection{Conclusion}

In conclusion, selective ammonium binding and fluorescence sensing by tripodal pyrazolyl receptors was demonstrated. Fluorescence and ${ }^{1} \mathrm{H}-\mathrm{NMR}$ provide evidence of Ln(III) binding, with differences on pyrazole substitution greatly affecting binding and fluorescence effects. This is in consistent with the $\mathrm{NH}_{4}{ }^{+}$binding study (Chapter 2), where the role of ion-pairing plays a major role in the binding affinities. Theoretical DFT calculations and structural and spectroscopic investigations are expected to provide comparisons with An(III) binding and further understanding of observed selectivities.

\subsection{Experimental}

\subsubsection{Materials and methods}

All commercial reagents and solvents were purchased from Fisher Scientific or Sigma Aldrich and were used without further purification. 1,3,5-Tris(bromomethyl)benzene was 
either purchased from Sigma Aldrich or synthesized according to published literature procedures. ${ }^{1} \mathrm{H}-\mathrm{NMR}$ spectra were recorded on a $400 \mathrm{MHz}$ Bruker NMR spectrometer and were referenced using the residual solvent resonances. All chemical shifts, $\delta$, are reported in ppm. Fluorescence spectra were recorded on an Agilent technologies Cary Eclipse fluorimeter.

\subsection{2 ${ }^{1} \mathrm{H}-\mathrm{NMR}$ Titrations}

The association constants for the formation of cation-receptor complexes were determined by titration of solutions of $2.0 \times 10^{-3} \mathrm{M}$ of $\mathbf{1}$ or $\mathbf{2}$ in acetone- $\mathrm{d}_{6}$ (or acetonitrile- $\mathrm{d}_{3}$ for $\mathbf{3}$ ) (solution A) with $0.2 \mathrm{M}$ of $\mathrm{La}\left(\mathrm{NO}_{3}\right)_{3} \cdot 6 \mathrm{H}_{2} \mathrm{O}$ (solution B). Solution B was prepared by dilutions with solution A, thus keeping a constant concentration of $\mathbf{1}$ or $\mathbf{2}$ upon titration of solution A with solution B. In a typical experiment, solution A $\left(0.700 \mathrm{~mL}\right.$ for $\left.\mathrm{La}^{3+}\right)$ was placed in an NMR tube. Solution B was added in increments until a total of $950 \mu \mathrm{L}$ was added. The changes of chemical shifts were monitored, with the results plotted and fitted to the 1:1 binding isotherm (Eq. 1), using non-linear regression analysis.

\subsubsection{Fluorescence Titration of 1,2 or 3 with $\mathrm{Ln}\left(\mathrm{NO}_{3}\right)_{3} \cdot 6 \mathrm{H}_{2} \mathrm{O}$}

Fluorescence emissions were measured using an excitation wavelength of $272 \mathrm{~nm}$ for receptor $\mathbf{1}, 262 \mathrm{~nm}$ for receptor $\mathbf{2}$, or $230 \mathrm{~nm}$ for receptor $\mathbf{3}$, a measurement increment of $0.5 \mathrm{~nm}$, and integration time of $0.1 \mathrm{~s}$, excitation slit width of $10 \mathrm{~nm}$, emission slit width of $5 \mathrm{~nm}$. Experiments were run using receptor solutions of $\mathrm{R}\left(\mathrm{R}=\mathbf{1}, \mathbf{2}, \mathbf{3}, 1.0 \times 10^{-4} \mathrm{M}\right)$ in $\mathrm{CH}_{3} \mathrm{CN}$ (solution A), which were titrated with solutions of $\mathrm{Ln}\left(\mathrm{NO}_{3}\right)_{3} \cdot 6 \mathrm{H}_{2} \mathrm{O}\left(\mathrm{Ln}=\mathrm{La}^{3+}\right.$, $\mathrm{Nd}^{3+}, \mathrm{Lu}^{3+}, \mathrm{Ce}^{3+}, \mathrm{Eu}^{3+}$ and $\left.\mathrm{Sm}^{3+}, 1.0 \times 10^{-2} \mathrm{M}\right)$ and $\mathrm{R}(\mathrm{R}=\mathbf{1}, \mathbf{2}, \mathbf{3})\left(1.0 \times 10^{-4} \mathrm{M}\right)$ in $\mathrm{CH}_{3} \mathrm{CN}$ (solution B). $2000 \mu \mathrm{L}$ of solution A was added to the fluorescence cuvette and solution B 
was added in increments until a total of $1000 \mu \mathrm{L}$ was added. The fluorescence intensity at emission maxima was monitored.

4.6. References

(1) Hudson, M. J.; Harwood, L. M.; Laventine, D. M.; Lewis, F. W. Use of Soft Heterocyclic N-Donor Ligands To Separate Actinides and Lanthanides. Inorg. Chem. 2013, 52, 3414-3428.

(2) Bhattacharyya, A.; Mohapatra P. K.; Manchanda, V. K. Separation of Americium(III) and Europium(III) from Nitrate Medium Using a Binary Mixture of Cyanex-301 with N-donor Ligands. Solvent Extr. Ion Exch. 2006, 24, 1-17.

(3) Salvatores, M.; Palmiotti, G. Radioactive Waste Partitioning and Transmutation within Advanced Fuel Cycles: Achievements and Challenges. Prog. Part. Nucl. Phys. 2011, 66, 144-166.

(4) Panak, P. J.; Geist, A. Complexation and Extraction of Trivalent Actinides and Lanthanides by Triazinylpyridine N-Donor Ligands. Chem. Rev. 2013, 113, 1199-1236.

(5) Demir, S.; Brune, N. K.; Van Humbeck, J. F.; Mason, J. A.; Plakhova, T. V.; Wang, S.; Tian, G.; Minasian, S. G.; Tyliszczak, T.; Yaita, T.; Kobayashi, T.; Kalmykov, S. N.; Shiwaku, H.; Shuh, D. K.; Long, J. R. Extraction of Lanthanide and Actinide Ions from Aqueous Mixtures Using a Carboxylic Acid-Functionalized Porous Aromatic Framework. ACS Cent. Sci. 2016, 2, 253-265.

(6) Edwards, A. C.; Wagner, C.; Geist, A.; Burton, N. A.; Sharrad, C. A.; Adams, R. W.; Pritchard, R. G.; Panak, P. J.; Whitehead, R. C.; Harwood, L. M. Exploring Electronic Effects on the Partitioning of actinides(III) from lanthanides(III) Using Functionalised Bis-Triazinyl Phenanthroline Ligands. Dalton Trans. 2016, 45, 18102-18112.

(7) Macerata, E.; Mossini, E.; Scaravaggi, S.; Mariani, M.; Mele, A.; Panzeri, W.; Boubals, N.; Berthon, L.; Charbonnel, M.-C.; Sansone, F.; Arduini, A.; Casnati, A. Hydrophilic Clicked 2,6-Bis-Triazolyl-Pyridines Endowed with High Actinide Selectivity and Radiochemical Stability: Toward a Closed Nuclear Fuel Cycle. J. Am. Chem. Soc. 2016, 138, 7232-7235.

(8) Geist, A.; Müllich, U.; Magnusson, D.; Kaden, P.; Modolo, G.; Wilden, A.; Zevaco, T. Actinide(III)/Lanthanide(III) Separation Via Selective Aqueous Complexation of Actinides(III) Using a Hydrophilic 2,6-Bis(1,2,4-Triazin-3-Yl)-Pyridine in Nitric Acid. Solvent Extr. Ion Exch. 2012, 30, 433-444. 
(9) Zalupski, P. R.; Nash, K. L.; Martin, L. R. Thermodynamic Features of the Complexation of Neodymium(III) and Americium(III) by Lactate in Trifluoromethanesulfonate Media. J. Solut. Chem. 2010, 39, 1213-1229.

(10) Güllü, F.; Bayrakc1, M.; Kursunlu, A. N.; Yiğiter, Ş.; Ertul, Ş. Synthesis and Trivalent Lanthanide Ion Complexation Studies of New Macrocyclic Receptors Based Lactam Ionophores. J. Incl. Phenom. Macrocycl. Chem. 2014, 80, 303-312.

(11) Bekiari, V.; Judeinstein, P.; Lianos, P. A Sensitive Fluorescent Sensor of Lanthanide Ions. J. Lumin. 2003, 104, 13-15.

(12) Aoki, S.; Kawatani, H.; Goto, T.; Kimura, E.; Shiro, M. A Double-Functionalized Cyclen with Carbamoyl and Dansyl Groups $($ Cyclen $=1,4,7,10$ Tetraazacyclododecane): A Selective Fluorescent Probe for $\mathrm{Y}^{3+}$ and $\mathrm{La}^{3+}$. J. Am. Chem. Soc. 2001, 123, 1123-1132.

(13) Ghosh, P.; Shukla, A. D.; Das, A. Cerium Ion-Induced Fluorescence Enhancement of a Tripodal Fluoroionophore. Tetrahedron Lett. 2002, 43, 7419-7422.

(14) Wietzke, R.; Mazzanti, M. Strong Intramolecular $[\pi]-[\pi]$ Interactions Favor the Formation of 2:1 (L:M) Lanthanide Complexes of tris(2Benzimidazolylmethyl)amine. Chem. Commun. 1999, 209-210.

(15) Badr El Aroussi, B.E.; Dupont,N.; Bernardinelli, G.; Hamacek. J. Unsymmetrical Tripodal Ligand for Lanthanide Complexation: Structural, Thermodynamic, and Photophysical Studies. Inorganic Chemistry. 2010, 49, 606-615.

41. (16) Chin, J.; Walsdorff, C.; Stranix, B.; Oh, J.; Chung, H. J.; Park, S. M.; Kim, K. A Rational Approach to Selective Recognition of $\mathrm{NH}_{4}{ }^{+}$over $\mathrm{K}^{+}$. Angew. Chemie - Int. Ed. 1999, 38, 2756-2759. 


\section{CHAPTER V}

\section{$\mathrm{Hg}(\mathrm{II})$ complexation and sensing by a tris-dansylamide derivative of}

\section{1,3,5-Tris(2-aminomethyl) -2,4,6-triethylbenzene.}

Tosin M. Jonah, Logesh Mathivathanan, Gabriel Flores, Raphael G. Raptis, Konstantinos Kavallieratos

Department of Chemistry and Biochemistry and the Biomolecular Sciences Institute, Florida International University, 11200 SW $8^{\text {th }}$ St, Miami, FL 33199, USA.
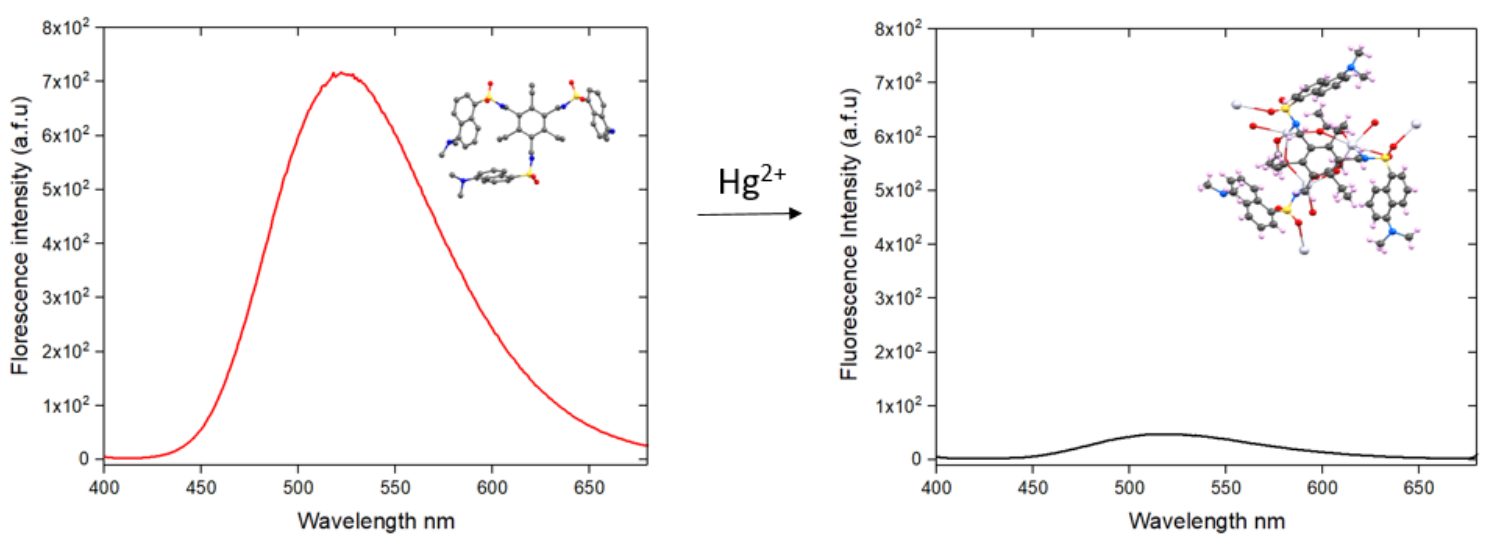


\section{$5.1 \quad$ Abstract}

A new tripodal fluorescent receptor $\mathbf{L H}_{3}$ based on dansyl fluorophore for $\mathrm{Hg}$ (II) was developed. The receptor showed selectivity towards $\mathrm{Hg}(\mathrm{II})$. The X-ray crystal structure obtained from the complex formed between $\mathrm{LH}_{3}$ and $\mathrm{Hg}\left(\mathrm{CH}_{3} \mathrm{COO}\right)_{2}$ shows that one molecule of $\mathbf{L H}_{3}$ binds three molecules of $\mathrm{Hg}^{2+}$, while the analogous structure obtained for $\mathbf{L H}_{3}$ and $\mathrm{HgCl}_{2}$ revealed that just one of the sulfonamide groups in $\mathbf{L H}_{3}$ is deprotonated and two molecules of $\mathbf{L H}_{3}$ bind to a single $\mathrm{Hg}(\mathrm{II})$.

\subsection{Introduction}

Over the last few decades, much research effort has been dedicated to the design and synthesis of selective $\mathrm{Hg}$ (II) receptors and sensors. This effort arises from the toxic nature of mercury to both the human health and the environment. ${ }^{1,2}$ Mercury is ranked among the priority metals that are of public health significance. ${ }^{3}$ These metallic elements are considered systemic toxicants that are known to induce multiple organ damage, even at lower levels of exposure. The pollution has been shown to originate from both natural and anthropogenic sources. Minamata disease ${ }^{4}$ and prenatal brain damage are some of the hazardous effects that arise from mercury exposure in humans. ${ }^{5-9}$

In recent years, numerous methods have been employed in the detection of $\mathrm{Hg}(\mathrm{II})$, including colorimetric sensing techniques, atomic absorption, X-ray fluorescence spectroscopy and electrochemical sensing. The use of colorimetric and fluorescence sensors for $\mathrm{Hg}$ (II) detection stems from the low cost, operational simplicity and high selectivity. An example is the highly selective and sensitive colorimetric method based on gold nanoparticles that utilizes gold amalgamation and grown Au nanoparticles for rapid 
$\mathrm{Hg}$ (II) detection. ${ }^{10-13}$ Moreover, a number of fluorescence chemosensors have been reported in the literature for $\mathrm{Hg}$ (II) detection. Che et al. reported a fluorescent 5-bromoindole-3-carboxaldehyde ethylthiosemicarbazone receptor that can detect and remove $\mathrm{Hg}$ (II) from water by extraction. ${ }^{14}$ This ligand coordinates directly to $\mathrm{Hg}$ (II) through its $\mathrm{N}$ and $\mathrm{S}$ atoms. It also showed good selectivity towards $\mathrm{Hg}(\mathrm{II})$, with a detection limit of $1.31 \times 10^{-7} \mathrm{M}$. Compounds containing the rhodamine fluorophore ${ }^{15-19}$ have found many uses due to their emissive performance ${ }^{20}$ and emission turn-on effect, which is caused by $\mathrm{Hg}(\mathrm{II})$ ions. The dansylamide fluorophore has also found uses as fluorescent probe because it possesses high fluorescence quantum yield and large stokes shifts. A few dansylbased receptors have been reported for $\mathrm{Hg}$ (II) detection..$^{21-25}$

In this work, we combined the optical properties of dansyl fluorophore and its $\mathrm{N}$-donor atoms in the synthesis of a tripodal receptor $\mathbf{L H}_{3}$, based on the same successful 1,3,5triethylbenzene framework used for the $\mathrm{NH}_{4}{ }^{+}$and $\mathrm{Ln}$ (III) sensing work (Chapters 2-4), by incorporating three dansyl groups that can bind to $\mathrm{Hg}(\mathrm{II})$ when deprotonated, while maintaining the fluorescence sensing capacity of the dansyl group. The dansylated receptor $\mathbf{L H}_{3}$ can be synthesized in good yields, in only a few synthetic steps (Chapter 3).
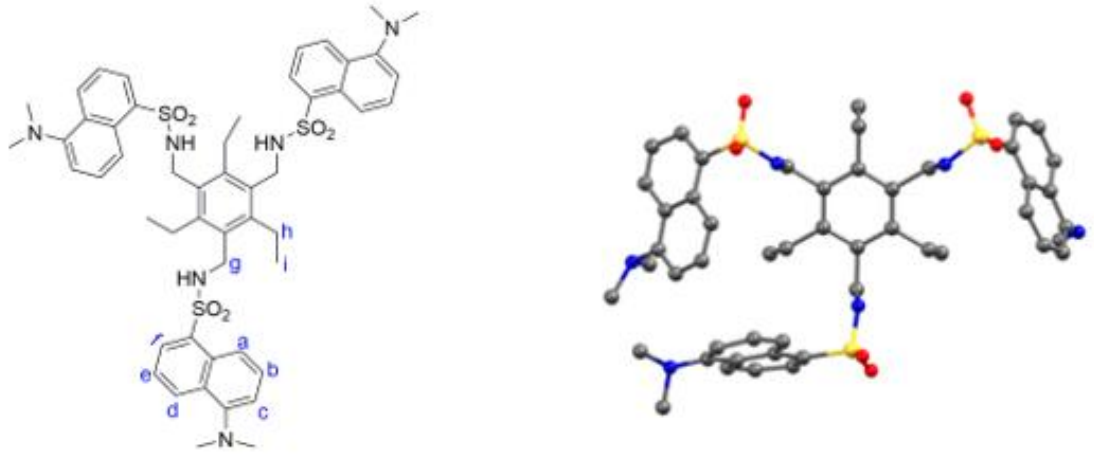

Figure 5.1. Chemical and crystal structures of receptor $\mathbf{L H}_{3}$. 


\subsection{Results and Discussion}

Compound $\mathbf{L H}_{3}$ was prepared as previously reported (Chapter 3) by adding a solution of 1,3,5-tris(aminomethyl)-2,4,6-triethylbenzene ${ }^{26}$ and triethylamine in anhydrous 1,2DCE to a stirring solution of dansyl chloride dissolved in 1,2-DCE. The mercury binding and sensing properties were investigated by ${ }^{1} \mathrm{H}-\mathrm{NMR}$ and fluorescence spectroscopy. The fluorescence emission intensity of the free receptor $\mathrm{LH}_{3}$ and the changes in the emission intensity in the presence of the mercury (added as $\mathrm{Hg}\left(\mathrm{CH}_{3} \mathrm{COO}\right)_{2}$ or $\mathrm{HgCl}_{2}$ ) are shown in figure 5.2 and 5.3. Fluorescence titrations of $\mathbf{L H}_{3}$ with $\mathrm{Hg}\left(\mathrm{CH}_{3} \mathrm{COO}\right)_{2}$ and $\mathrm{HgCl}_{2}$ at constant receptor concentration of $1 \mu \mathrm{M}$ were carried out in $\mathrm{CH}_{3} \mathrm{OH}\left(\lambda_{\mathrm{exc}}=350 \mathrm{~nm}\right)$. The fluorescence titration results showed that the fluorescence emission intensity at $522 \mathrm{~nm}$ decreased with the addition of $\mathrm{Hg}(\mathrm{II})$ without any considerable shift in the emission maximum. By the time the titration was finished, the fluorescence intensity of $\mathbf{L H}_{3}$ was almost completely quenched by the addition of $\mathrm{Hg}\left(\mathrm{CH}_{3} \mathrm{COO}\right)_{2}$. Fluorescence quenching is measured quantitatively with the Stern-Volmer equation (eqn. 5.1) where, the quencher concentration is $[\mathrm{Q}]$, the Stern-Volmer constant is $\mathrm{K}_{\mathrm{sv}}, \mathrm{I}_{\mathrm{o}}$ is the measured fluorescence intensity without quencher present, and I is the measured fluorescence intensity with [Q] present.

$$
\mathrm{Io} / \mathrm{I}=1+\mathrm{K}_{\mathrm{sv}}[\mathrm{Q}] \ldots \ldots \ldots \ldots . . \text { eqn. } 5.1
$$

At lower concentrations of $\mathrm{Hg}(\mathrm{II})$, a plot of $\mathrm{I}_{0} / \mathrm{I}$ vs $[\mathrm{Hg}(\mathrm{II})]$ is linear, (figure 5.4) and the slope obtained gives the Stern-Volmer constants $\left(\mathrm{K}_{\mathrm{sv}}\right)$ as $4.3 \times 10^{4}$ and $2.3 \times 10^{5} \mathrm{M}^{-1}$ for $\mathrm{LH}_{3}$ with $\mathrm{Hg}\left(\mathrm{CH}_{3} \mathrm{COO}\right)_{2}$ and $\mathrm{HgCl}_{2}$, respectively. 


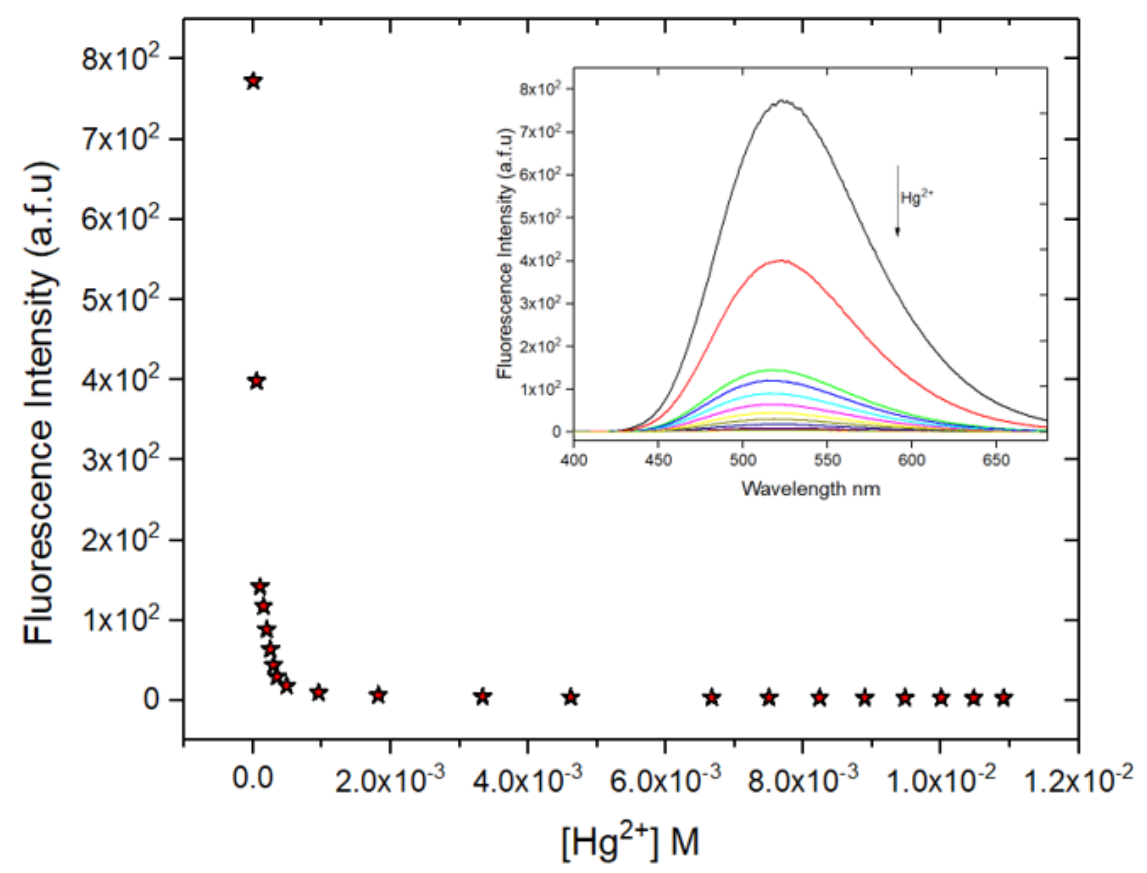

Figure 5.2. Fluorescence titration of $\mathbf{L H}_{3}\left(1.0 \times 10^{-6} \mathrm{M}\right)$ with $\mathrm{Hg}\left(\mathrm{CH}_{3} \mathrm{COO}\right)_{2}$ in methanol.

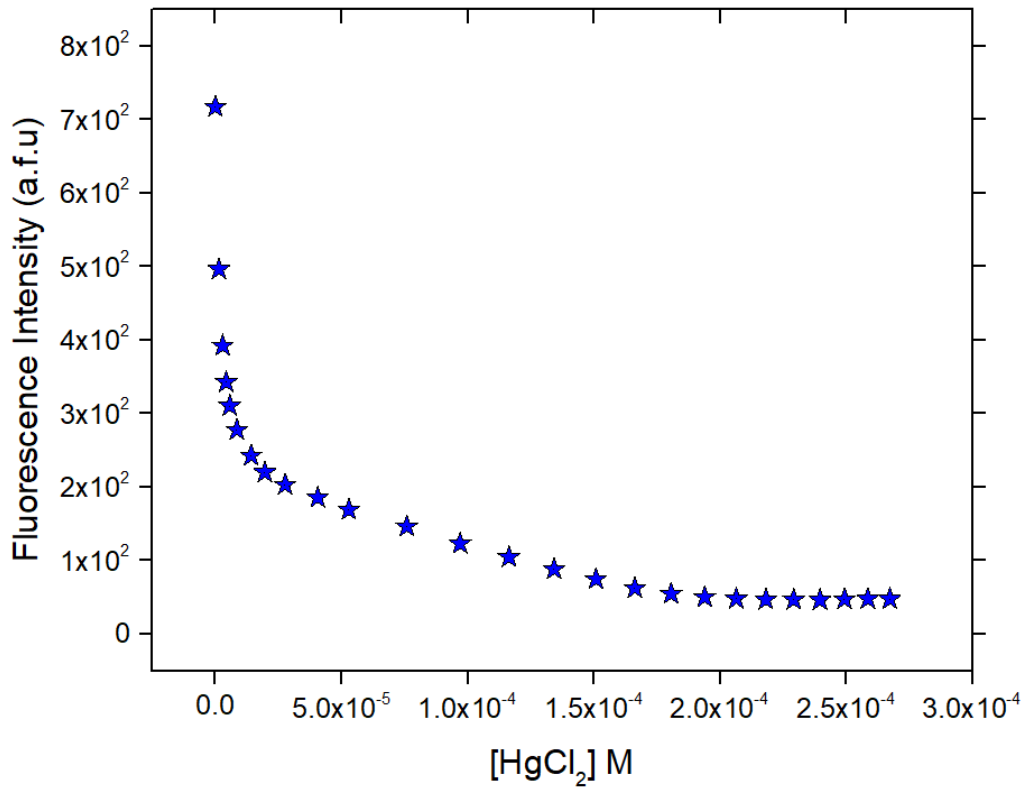

Figure 5.3. Fluorescence titration of $\mathbf{L H}_{3}\left(1.0 \times 10^{-6} \mathrm{M}\right)$ with $\mathrm{HgCl}_{2}$ in methanol. 


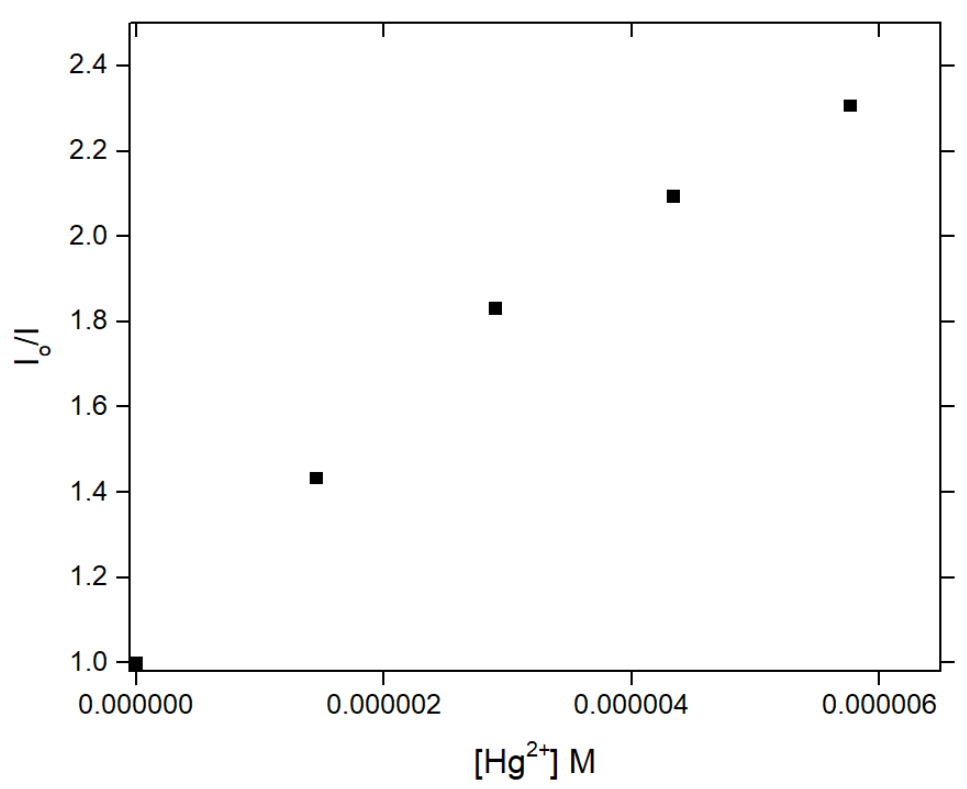

Figure 5.4. Stern- Volmer plot of $\mathbf{L H}_{3}\left(1.0 \times 10^{-6} \mathrm{M}\right)$ with low concentration of $\mathrm{HgCl}_{2}$ in methanol.

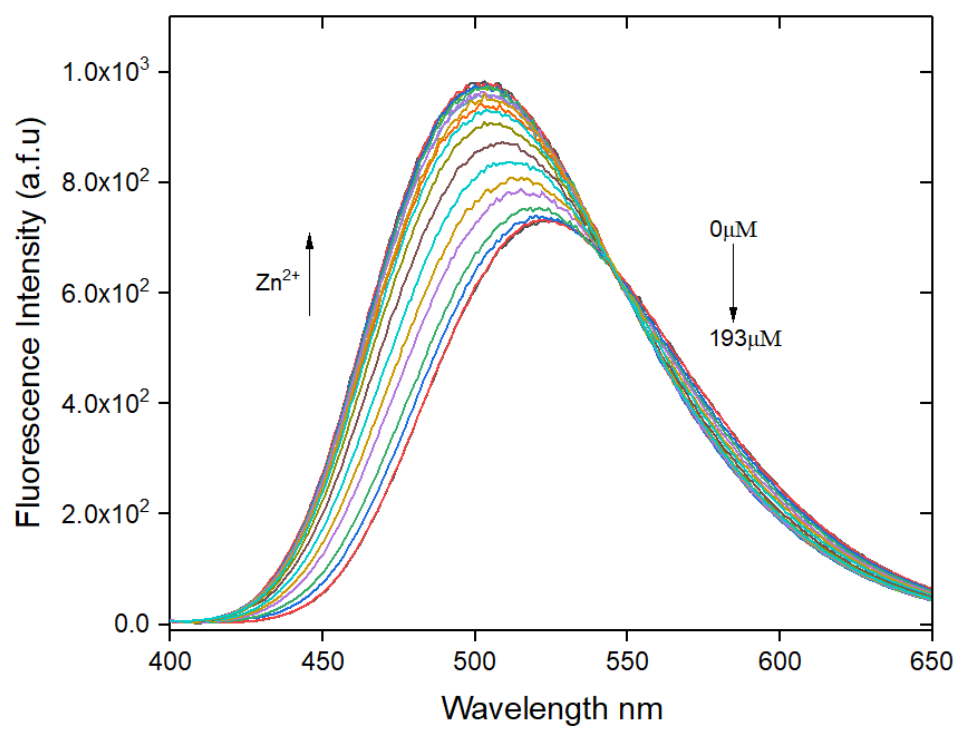

Figure 5.5 Fluorescence titration of $\mathrm{LH}_{3}\left(1.0 \times 10^{-6} \mathrm{M}\right)$ with $\mathrm{ZnCl}_{2}$ in $\mathrm{CH}_{3} \mathrm{OH}$.

Selectivity studies were also carried out on $\mathbf{L H}_{3}$ in methanol solution monitoring the changes in fluorescence emission intensity of $\mathbf{L H}_{3}$ with addition of other cations, such as 
$\mathrm{Ag}^{+}, \mathrm{Co}^{2+}, \mathrm{Ca}^{2+}, \mathrm{Cu}^{2+}, \mathrm{Zn}^{2+}$ and $\mathrm{Cd}^{2+}$. The fluorescence emission of $\mathbf{L H}_{3}$ with addition of these cations showed little to no change, except for $\mathrm{Zn}^{2+}$ which showed florescence enhancement. When $\mathrm{Zn}^{2+}$ was added to solution of $\mathbf{L H}_{3}$ in methanol, the emission maximum at $522 \mathrm{~nm}$ was blue-shifted by $31 \mathrm{~nm}$ with an increase in the fluorescence intensity (figure 5.5). The fluorescence results showed that $\mathbf{L H}_{3}$ is selective for $\mathrm{Hg}^{2+}$ (Figure 5.6) compared to the other cations used in the selectivity studies.

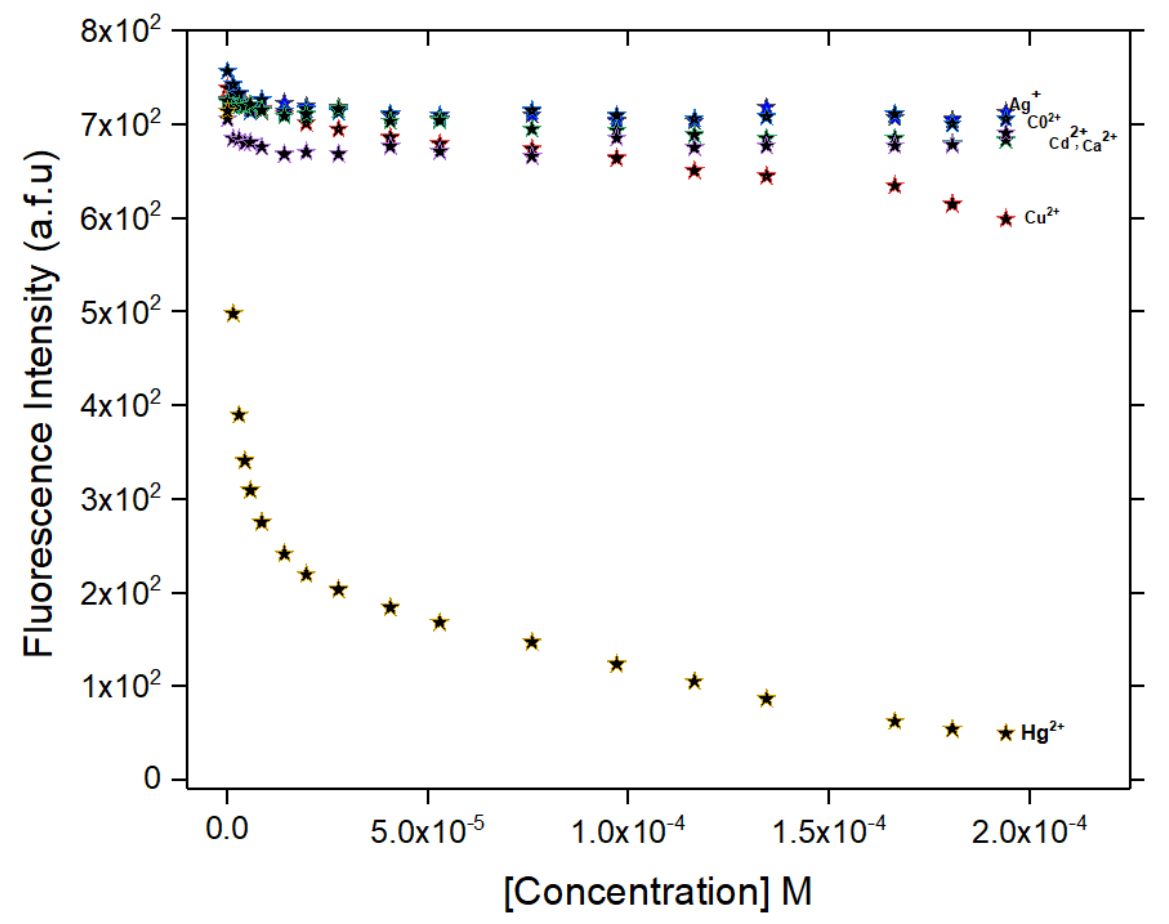

Figure 5.6. Fluorescence titration of $\mathrm{LH}_{3}\left(\lambda_{\mathrm{exc}}=350 \mathrm{~nm}, 1 \mu \mathrm{M}\right)$ with $\mathrm{Hg}^{2+}, \mathrm{Ag}^{+}, \mathrm{Co}^{2+}$, $\mathrm{Ca}^{2+}, \mathrm{Cu}^{2+}$ and $\mathrm{Cd}^{2+}(500 \mu \mathrm{M})$ in $\mathrm{CH}_{3} \mathrm{OH}$.

Competitive experiments were also performed in order to determine the sensing performance of $\mathbf{L H}_{3}$ for $\mathrm{Hg}(\mathrm{II})$ in the presence of competing cations. The fluorescence changes for formation of the complex of $\mathrm{LH}_{3}$ with $\mathrm{Hg}$ (II) were systematically examined in the presence of excess concentration of competing cations, such as $\mathrm{Ag}^{+}, \mathrm{Ca}^{2+}$, and $\mathrm{Co}^{2+}$. From the titration results, the fluorescence quenching observed was substantial in the 
presence of $\mathrm{Ca}$ (II) and even a mix of several competing cations, yet smaller than when $\mathrm{LH}_{3}$ was titrated with $\mathrm{HgCl}_{2}$ in the absence of those ions (Figure 5.7). It can be inferred from the results that the cations used in the competitive studies interact with $\mathbf{L H}_{3}$, but weaker than $\mathrm{Hg}$, and that $\mathrm{LH}_{3}$ can still be utilized as a receptor for $\mathrm{Hg}(\mathrm{II})$ even in the presence of higher backgrounds background $\mathrm{Ag}^{+}, \mathrm{Co}^{2+}$ and $\mathrm{Ca}^{2+}$.

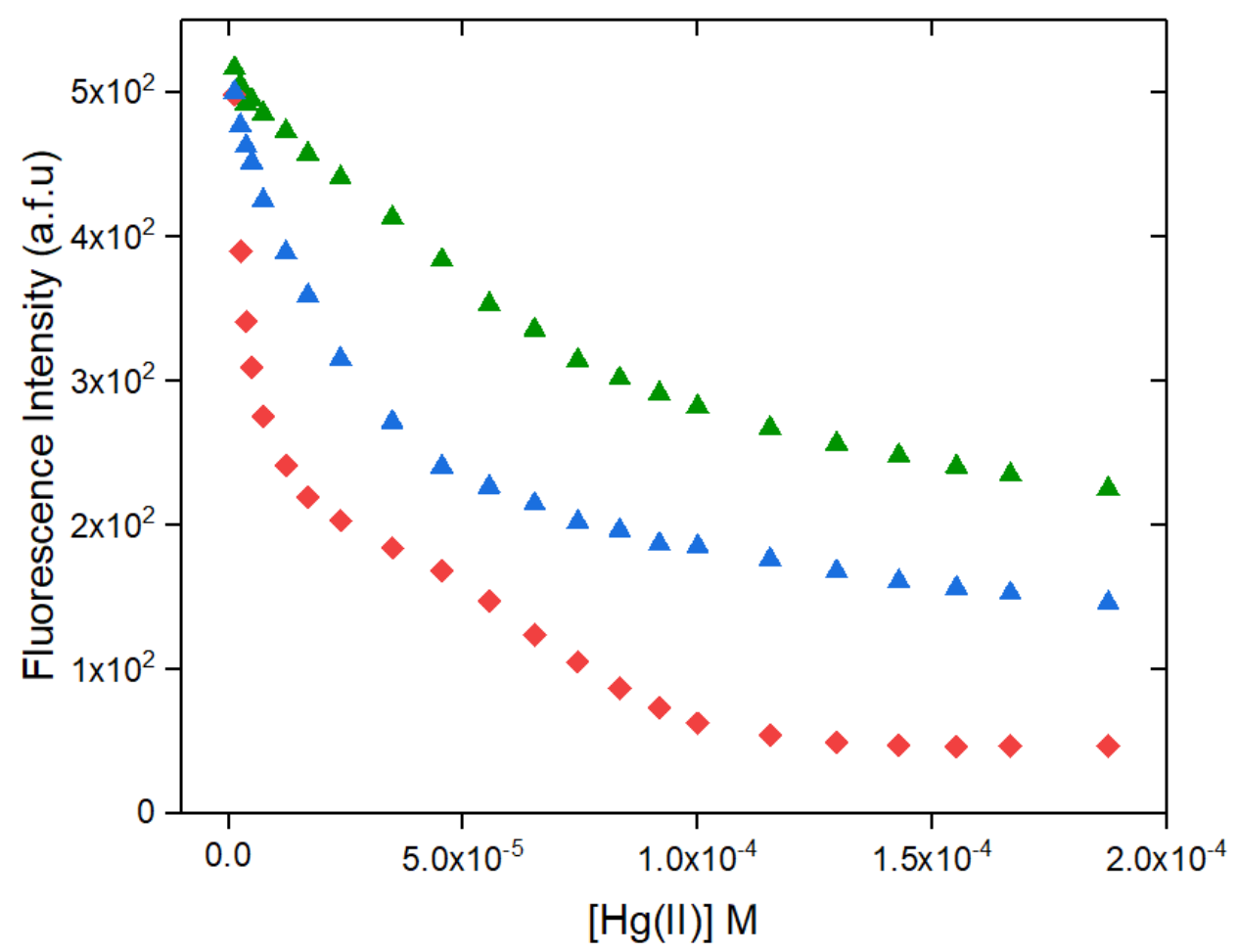

Figure 5.7 Fluorescence titrations of $\mathbf{L H}_{3}(1 \mu \mathrm{M})$ and $\mathrm{Et}_{3} \mathrm{~N}(3 \mu \mathrm{M})$ with $\mathrm{Hg}(\mathrm{II})$ in the presence of other cations in methanol $\left(\lambda_{\mathrm{exc}}=350 \mathrm{~nm}\right)$. The concentration of $\mathbf{L H}_{3}$ was stable at all experiments $(1 \mu \mathrm{M})$. Titration with $\mathrm{Hg}(\mathrm{II})$ in the absence of competing ions (red rhombus) in constant concentration of $\mathrm{Ca}$ (II) at $10 \mu \mathrm{M}$, (blue triangles), and in constant concentration $(10 \mu \mathrm{M})$ each of $\mathrm{Ag}^{+}, \mathrm{Co}^{2+}$, and $\mathrm{Ca}^{2+}$ (green triangles).

The $\mathrm{Hg}(\mathrm{II})$ binding properties of receptor $\mathbf{L H}_{3}$ were determined in DMSO-d 6 by ${ }^{1} \mathrm{H}-$ NMR titration experiments of $\mathbf{L H}_{3}$ (deprotonated with trimethylamine) with $\mathrm{HgCl}_{2} . \mathrm{Hg}$ (II) binds to $\mathrm{LH}_{3}$ through the nitrogen atoms of the sulfonamide group, which was also evident 
through the change in the chemical shifts of the naphthalene rings (downfield movements) present in $\mathbf{L H}_{3}$.

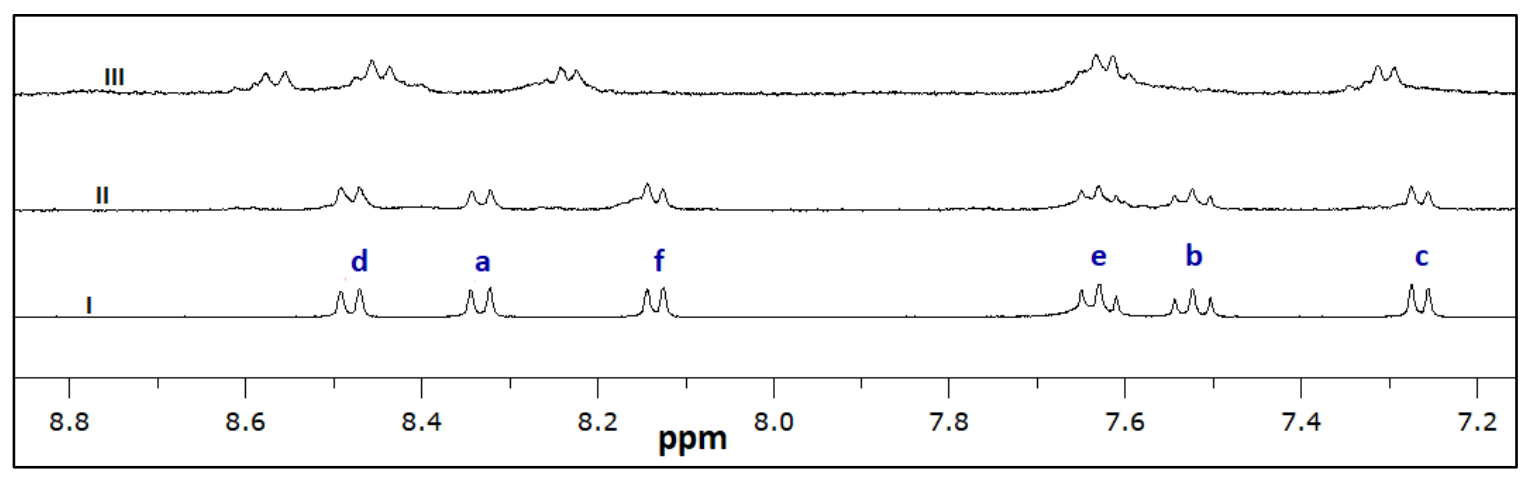

Figure 5.8: ${ }^{1} \mathrm{H}-\mathrm{NMR}$ titration experiments of $\mathbf{L H}_{3}$ with $\mathrm{HgCl}_{2}$ (deprotonated with 3 equivalents of triethylamine) in DMSO-d 6 . (i) $\mathbf{L H}_{3}$; (ii) $\mathbf{L H}_{3}$ with 1 equivalent of $\mathrm{Hg}$ (II); (iii) $\mathbf{L H}_{3}$ with 18 equivalent of $\mathrm{Hg}$ (II)

Crystals suitable for X-ray structural analysis for $\mathrm{Hg}_{3}(\mathbf{L})\left(\mathrm{CH}_{3} \mathrm{COO}\right)_{3}$ were obtained by slow evaporation of solutions of $\mathrm{LH}_{3}$ and $\mathrm{Hg}\left(\mathrm{CH}_{3} \mathrm{COO}\right)_{2}$ in methanol/acetone solution $(1: 1$ mol ratio). Crystals suitable for X-ray structural analysis for $\left[\mathrm{Hg}\left(\mathbf{L} \cdot \mathrm{H}_{2}\right)_{2}\left(\mathrm{H}_{2} \mathrm{O}\right)\right]$ was obtained from the slow evaporation of solutions of $\mathrm{LH}_{3}, \mathrm{HgCl}_{2}$, and trimethylamine.

Compound $\mathrm{Hg}_{3}(\mathbf{L})\left(\mathrm{CH}_{3} \mathrm{COO}\right)_{3}$ crystallizes in a triclinic space group, with the whole molecule present in the asymmetric unit. The crystallographic data is presented in Table 1. The ligand $\mathbf{L H}_{3}$ has three secondary amine nitrogen atoms that on deprotonation bind a $[\mathrm{Hg}(\mathrm{OAc})]^{-}$unit each. $\mathrm{Hg}^{2+}$ ions are present in a nearly linear geometry (are $176.9(4)^{\circ}$, 176.3(4) ${ }^{\circ}$ and $\left.175.4(3)^{\circ}\right)$ and $\mathrm{Hg}-\mathrm{N}$ distances: $2.037(9), 2.049(10)$ and 2.042(10) $\AA$, and Hg-O distances: 2.064(8), 2.049(10) and 2.061(9) А. All three Hg-ions have weak interactions with acetate ions bound to adjacent $\mathrm{Hg}$-atoms $(\mathrm{Hg}-\mathrm{O}$ distances larger than $2.5 \AA$ ). One of the $\mathrm{Hg}$ ions also has a weak interaction with a solvent methanol present in the crystal structure. The $\mathrm{Hg}$ atoms in a triangular arrangement are quite far from each 
other, at 4.8752(7), 5.1186(7) and 5.0750(7) $\AA$. However, the weak interactions with acetate $\mathrm{O}$-atoms form an interesting chair-like structure as shown in the figure 5.9 below.

Compounds containing the dansyl fluorophore have been extensively studied as sensors for various metal ions. However, only 31 hits were obtained for a dansylamide-M query in CSD (as of Sep 5, 2017, where M is any metal), and only one Hg-compound. This is the first time a tripodal ligand has been used to bind three $\mathrm{Hg}$-atoms at once.

The compound with the molecular formula, $\left[\mathrm{Hg}\left(\mathbf{L} \cdot \mathrm{H}_{2}\right)_{2}\left(\mathrm{H}_{2} \mathrm{O}\right)\right]$ crystallizes in the monoclinic $\mathrm{C} 2 / \mathrm{c}$ space group with one half of the molecule in the asymmetric unit (Figure 5.11). One of the three sulfonamide protons from each treb ligand is bound to the $\mathrm{Hg}$ cation forming a linear $\mathrm{N}-\mathrm{Hg}-\mathrm{N}$ arrangement $\left(\mathrm{N}-\mathrm{Hg}\right.$ 2.366(1) $\AA,\left\llcorner\mathrm{NHgN} 174.0(1)^{\circ}\right)$. A water molecule coordinates to $\mathrm{Hg}(\mathrm{O}-\mathrm{Hg} 2.6579(2) \AA)$, forming a T-shaped coordination geometry around mercury. The coordinated water molecule is disordered around a twofold axis and was refined with PARTS. The ethyl groups on the phenyl ring of treb face the direction opposite to the $\mathrm{Hg}$ cation, enabling a weak $\mathrm{Hg}-\pi$ interaction (3.576(2) $\AA$ ). The oxygen atoms from the sulfonamide groups involve in weak H-bonding interactions. One of the naphthyl rings from a dansyl group shows an intermolecular $\pi$ - $\pi$-stacking interaction (centroid-centroid distance $3.861 \AA$ ) (Figure 5.12). 


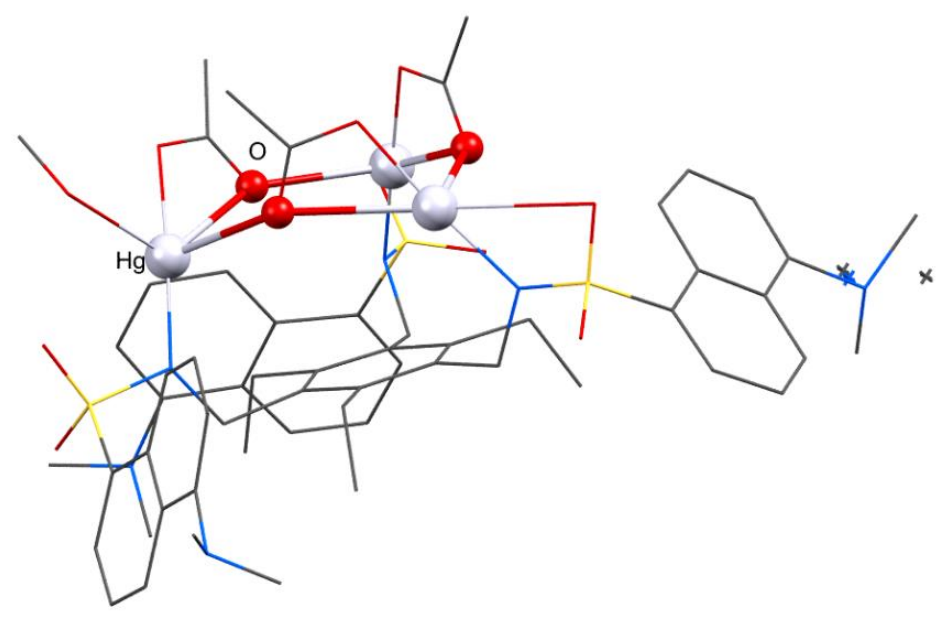

Figure 5.9. $X$-ray crystal structure of $\mathrm{Hg}_{3}(\mathbf{L})\left(\mathrm{CH}_{3} \mathrm{COO}\right)_{3}$ highlighting the chair conformation of the $\mathrm{Hg}_{3} \mathrm{O}_{3}$ unit.

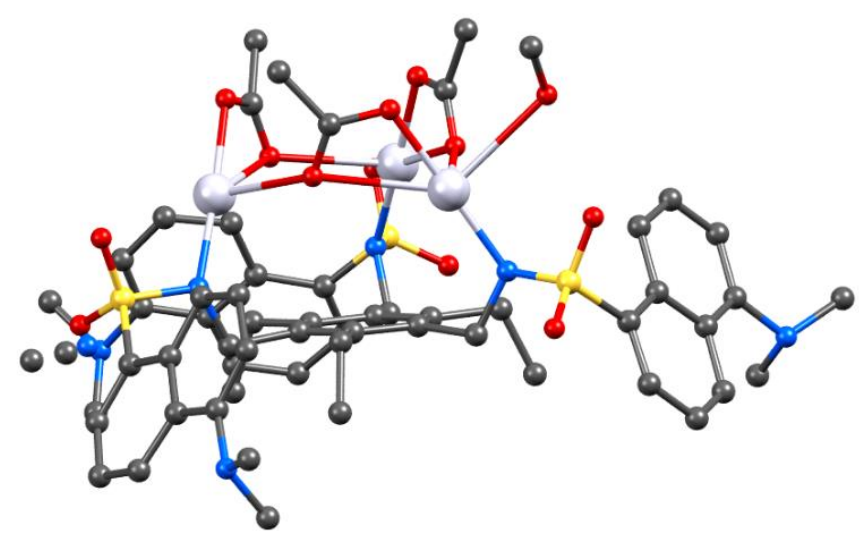

Figure 5.10. X-ray crystal structure of $\mathrm{Hg}_{3}(\mathbf{L})\left(\mathrm{CH}_{3} \mathrm{COO}\right)_{3}$. Hydrogen atoms are not shown for clarity. Color coding: silver, $\mathrm{Hg}$; red, O; yellow, S; blue, N; dark gray, C 


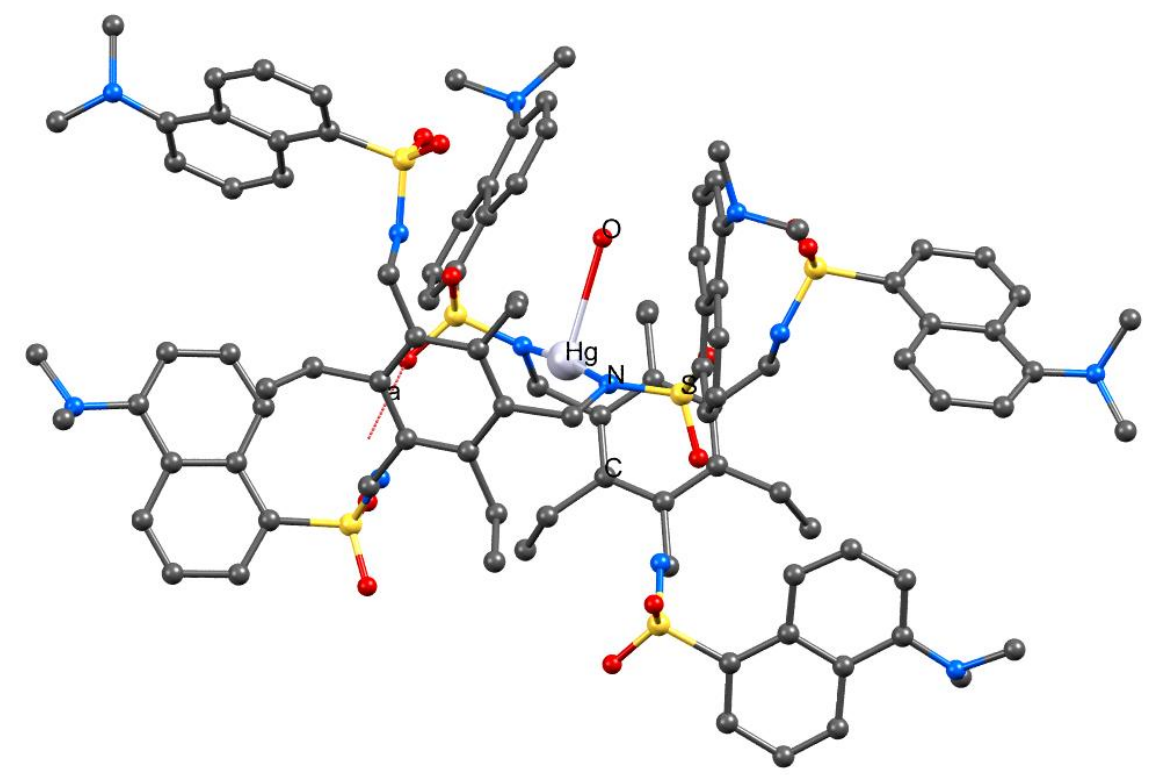

Figure 5.11. X-ray crystal structure of $\left[\mathrm{Hg}\left(\mathbf{L} \cdot \mathrm{H}_{2}\right)_{2}\left(\mathrm{H}_{2} \mathrm{O}\right)\right]$, Hydrogen atoms are not shown for clarity. Color coding: silver, Hg; red, O; yellow, S; blue, N; dark gray, C

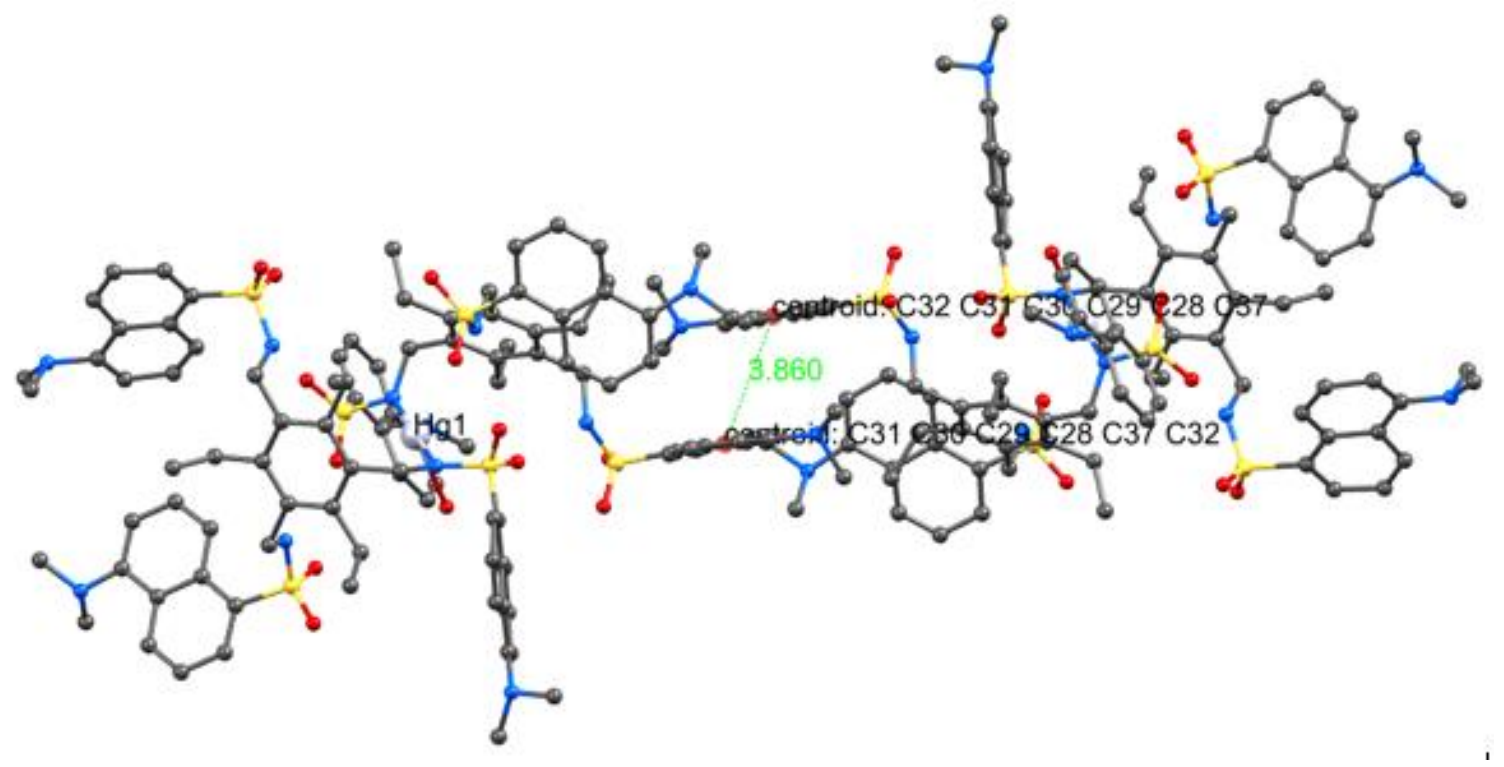

Figure 5.12. Ball and stick representation showing intermolecular $\pi-\pi$ interaction between two centroids. 
FT-IR spectroscopy was performed on the both the receptor $\mathbf{L H}_{3}$ (Figure 5.13) and the crystals of complex derived from $\mathbf{L H}_{3}$ with $\mathrm{HgCl}_{2}$ (Figure 5.15) or $\mathbf{L H}_{3}$ with $\mathrm{Hg}\left(\mathrm{CH}_{3} \mathrm{COO}\right)_{2}$ (Figure 5.14). The FT-IR spectrum of 1 shows the $\mathrm{N}-\mathrm{H}$ peak at $3272 \mathrm{~cm}^{-1}$. Upon complexation with mercury in $\mathrm{Hg}(\mathrm{II})$, the $\mathrm{NH}$ stretch at $3272 \mathrm{~cm}^{-1}$ has disappeared indicating that the sulfonamide ligand is deprotonated in the $\mathbf{L} \cdot \mathbf{H g}(\mathrm{II})$ complex. Another noticeable difference in the structures is the shift of the symmetric stretch of sulfonyl bands from $1142 \mathrm{~cm}^{-1}$ in the IR spectrum of $\mathbf{L H}_{3}$ to a lower frequency $1125 \mathrm{~cm}^{-1}$ in the $\mathrm{Hg}_{3}(\mathbf{L})\left(\mathrm{CH}_{3} \mathrm{COO}\right)_{3}$ complex. In the crystal structure of the complex derived from $\mathbf{L H}_{3}$ with $\mathrm{HgCl}_{2}$, the sulfonyl band at $1142 \mathrm{~cm}^{-1}$ is now split into two bands appearing at $1163 \mathrm{~cm}^{-1}$ and $1127 \mathrm{~cm}^{-1}$. This shift indicates that the sulfonamide groups of $\mathbf{L H}_{3}$ are involved in coordination with $\mathrm{Hg}$ (II). Figure 5.16 shows an overlay between $\mathbf{L H}_{3}$ and the $\left[\mathrm{Hg}\left(\mathbf{L H}_{2}\right)_{2}\left(\mathrm{H}_{2} \mathrm{O}\right)\right]$ complex formed between $\mathbf{L H}_{3}$ and $\mathrm{HgCl}_{2}$.

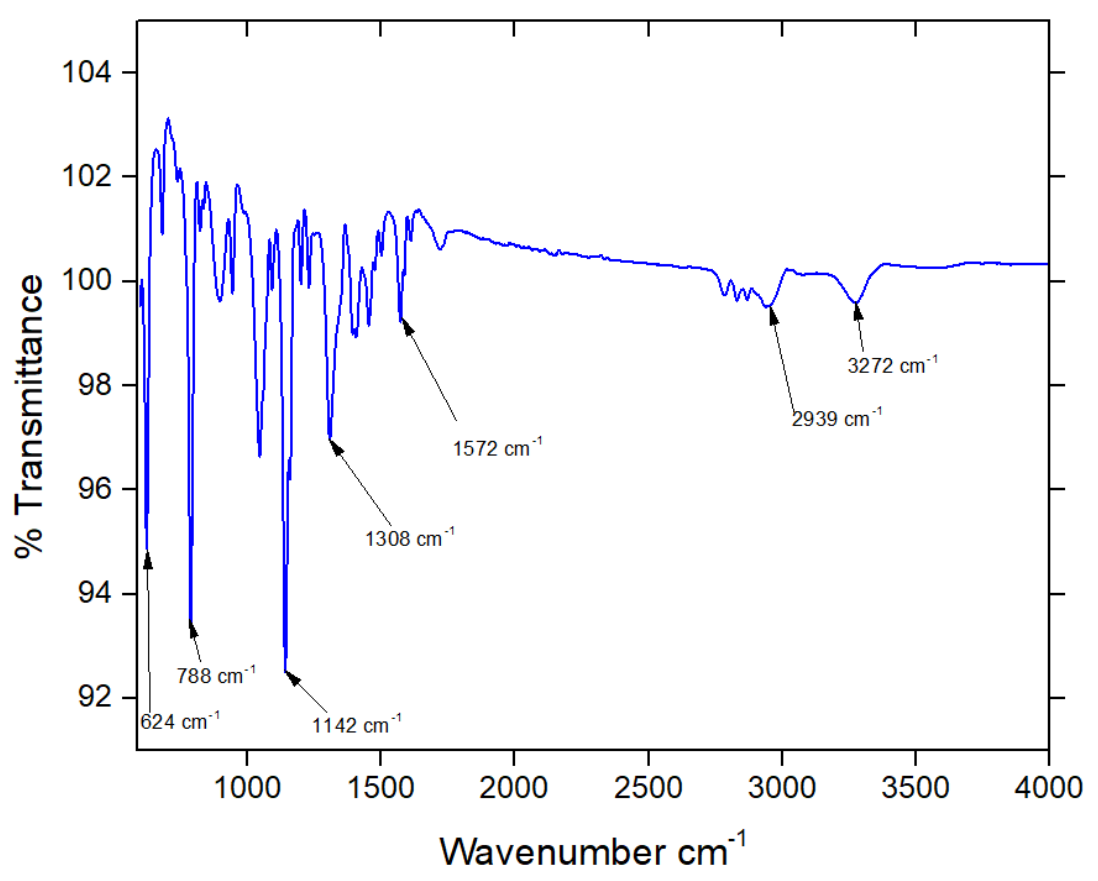

Figure 5.13. FT-IR spectrum of $\mathbf{L H}_{3}$ 


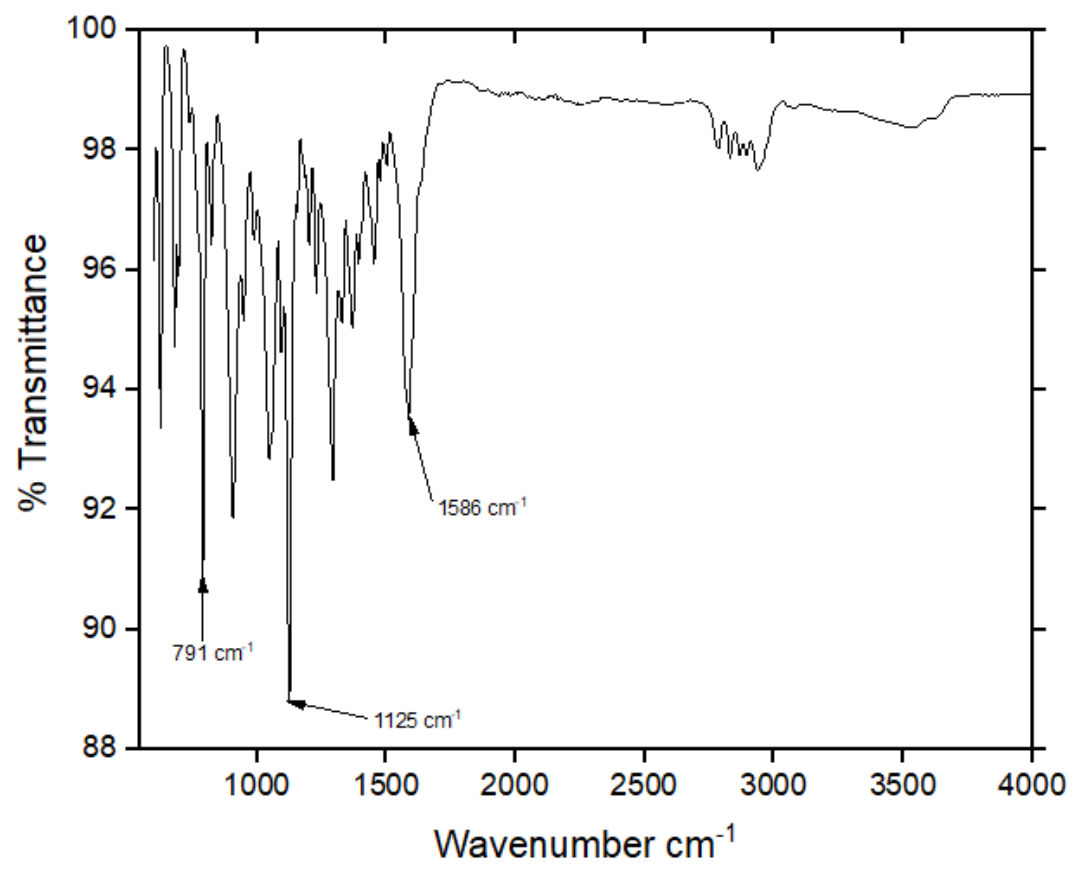

Figure 5.14. FT-IR spectrum of crystals of $\mathrm{Hg}_{3}(\mathbf{L})\left(\mathrm{CH}_{3} \mathrm{COO}\right)_{3}$.

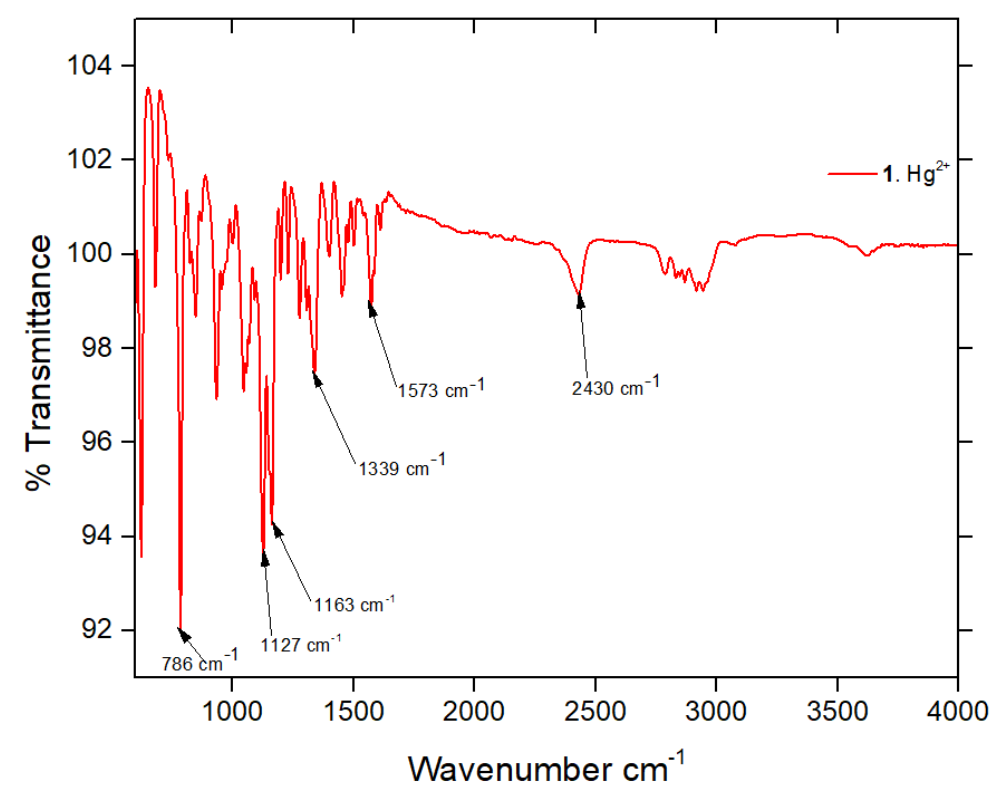

Figure 5.15. FT-IR spectrum of crystals of $\left[\mathrm{Hg}\left(\mathbf{L} \cdot \mathrm{H}_{2}\right)_{2}\left(\mathrm{H}_{2} \mathrm{O}\right)\right]$. 


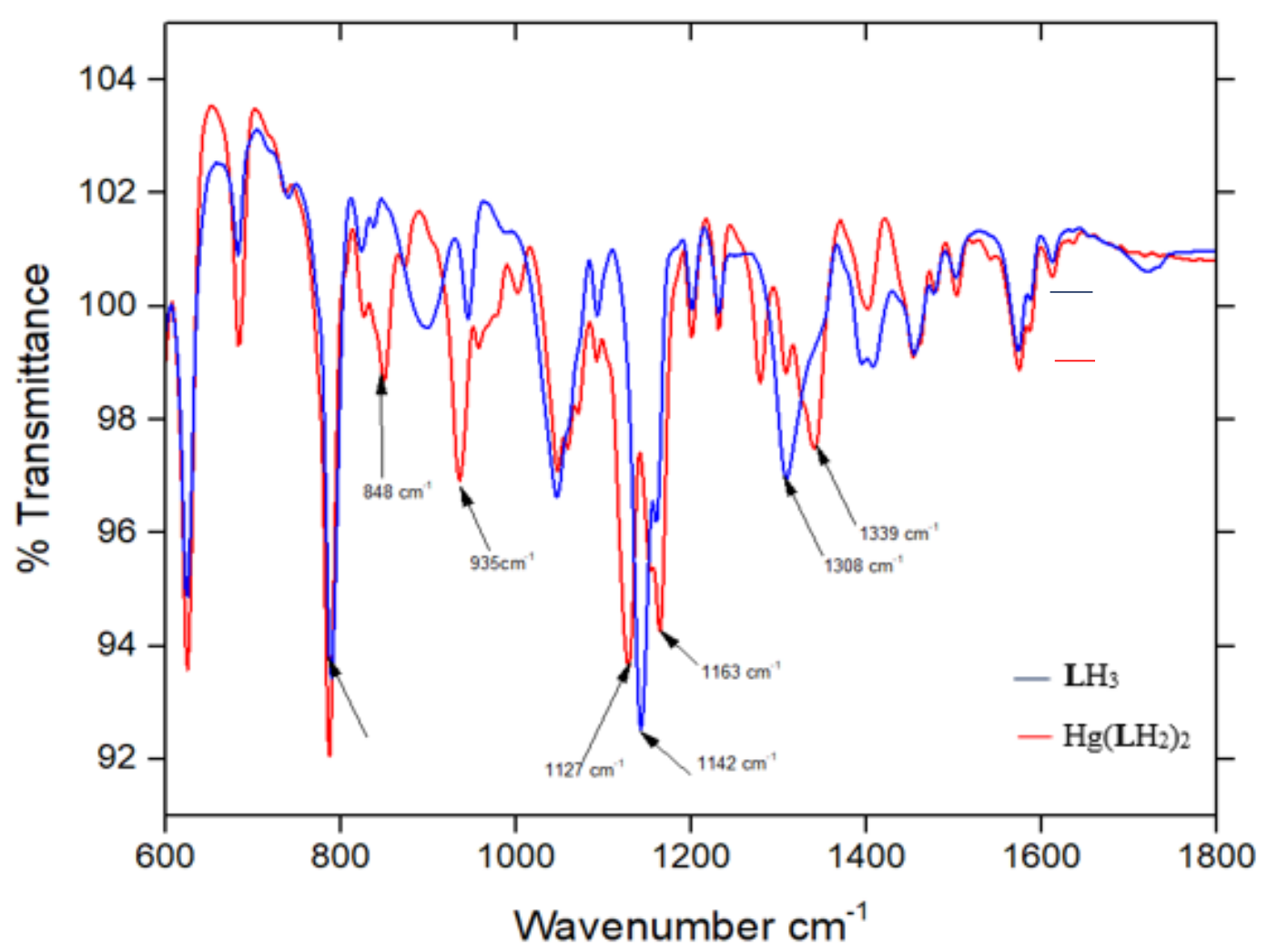

Figure 5.16. Overlay of the FT-IR spectra (crystals) of $\left[\mathrm{Hg}\left(\mathbf{L} \cdot \mathrm{H}_{2}\right)_{2}\left(\mathrm{H}_{2} \mathrm{O}\right)\right]$ and $\mathbf{L H}_{3}$

\subsection{Conclusion}

In conclusion, we have studied a fluorescence receptor $\mathrm{LH}_{3}$ that possesses high selectivity for $\mathrm{Hg}(\mathrm{II})$, even in the presence of competing ions. The fluorescence of $\mathrm{LH}_{3}$ was almost completely quenched by the addition of $\mathrm{HgCl}_{2}$ or $\mathrm{Hg}\left(\mathrm{CH}_{3} \mathrm{COO}\right)_{2}$. The crystal structure of the complexes formed between $\mathrm{LH}_{3}$ and $\mathrm{Hg}\left(\mathrm{CH}_{3} \mathrm{COO}\right)_{2}$ shows that one molecule of $\mathbf{L H}_{3}$ binds three $\mathrm{Hg}$ (II) while the complexed obtained from $\mathbf{L H}_{3}$ and $\mathrm{HgCl}_{2}$ revealed that just one of the sulfonamide $\mathrm{N}-\mathrm{H}$ in $\mathbf{L} \mathrm{H}_{3}$ was deprotonated and two molecules of $\mathbf{L H}_{3}$ bind to one $\mathrm{Hg}(\mathrm{II})$. 


\subsection{Experimental}

\subsubsection{Materials and methods}

All commercial reagents and solvents were purchased from Fisher Scientific or Sigma Aldrich and were used without further purification. 1,3,5-Tris(aminomethyl)-2,4,6triethylbenzene was synthesized as previously reported. ${ }^{26}{ }^{1} \mathrm{H}$ and ${ }^{13} \mathrm{C}-\mathrm{NMR}$ spectra were recorded on a $400 \mathrm{MHz}$ Bruker NMR spectrometer and were referenced, using the residual solvent resonances. All chemical shifts, $\delta$, are reported in ppm. FT-IR spectra were recorded on a Agilent Technologies Cary 600 series FT-IR Spectrometer. Fluorescence spectra were recorded on a Agilent Technologies Cary Eclipse fluorescence spectrophotometer. X-ray diffraction data were collected from single crystals mounted atop a glass fiber with a Bruker AXS SMART 1K CCD area detector with graphite monochromated Mo K $\alpha$ radiation $(\lambda=0.71073 \AA)$ using the program SMART-NT ${ }^{3}$ and

processed by SAINT-NT. ${ }^{4}$ An empirical absorption correction was applied by the program SADABS. The structures were solved by intrinsic phase method and refined by full matrix least-squares methods on $\mathrm{F}^{2} \cdot{ }^{5}$ All non-hydrogen atoms were refined anisotropically, while $\mathrm{H}$-atoms were placed in calculated positions with their thermal parameters riding on those of their $\mathrm{C}$ atoms.

\subsection{2 ${ }^{1}$ H-NMR Titrations of 1,3,5-Tris-(5-dimethylamino-1 naphthalenesulfonamido)methyl]-2,4,6-triethylbenzene with $\mathrm{HgCl}_{2}$}

The association constants for the formation of cation-receptor complexes were determined by titration of solution of $2 \times 10^{-3} \mathrm{M}$ of the ligand in DMSO-d 6 (solution A) with $0.1 \mathrm{M}$ of $\mathrm{HgCl}_{2}$ (solution $\mathrm{B}$ ). Solution $\mathrm{B}$ was prepared by dilutions with solution $\mathrm{A}$, thus keeping a constant concentration of $\mathbf{L H}_{3}$ upon titration of solution A with solution B. 
$6.0 \times 10^{-3} \mathrm{M}$ trimethylamine was added into the stock solution A to deprotonate the ligand. In a typical experiment, solution A $(0.700 \mathrm{ml})$ was placed in an NMR tube. Solution B was added in increments until a total of $950 \mu 1$ was added. The changes of chemical shifts were monitored, with the results plotted and fitted to the 1:1 binding isotherm (Eq.1) using nonlinear regression analysis:

$\left.\Delta \delta=\delta_{\text {obs }}-\delta_{2}=\left([\mathbf{R}]_{\mathrm{t}}+\left[\mathrm{X}^{-}\right]_{\mathrm{t}}+\mathrm{K}_{\mathrm{a}}^{-1}-\left(\left(\left([\mathbf{R}]_{\mathrm{t}}+\left[\mathrm{X}^{-}\right]_{\mathrm{t}}+\mathrm{K}_{\mathrm{a}}^{-1}\right)^{2}-4\left[\mathrm{X}^{-}\right]_{\mathrm{t}}[\mathbf{R}]_{\mathrm{t}}\right)^{1 / 2}\right)\right) \Delta \delta_{\max }\right) /\left(2[\mathbf{R}]_{\mathrm{t}}\right)$ (Eq.1)

\subsubsection{Fluorescence Titration of 1 with $\mathrm{HgCl}_{2}$ and $\mathrm{Hg}\left(\mathrm{CH}_{3} \mathrm{COO}\right)_{2}$}

Fluorescence emission was measured using an excitation wavelength of $350 \mathrm{~nm}$ for receptor $\mathbf{L H}_{3}$, a measurement increment of $0.5 \mathrm{~nm}$, and integration time of $0.1 \mathrm{~s}$, excitation slit width of $10 \mathrm{~nm}$, and emission slit width of $10 \mathrm{~nm} .3 \times 10^{-6} \mathrm{M}$ trimethylamine was added into the stock solution of $\mathrm{LH}_{3}$ to deprotonate the ligand when titrating with $\mathrm{HgCl}_{2}$. Experiments were run using solutions of $\mathrm{LH}_{3}\left(1.0 \times 10^{-6} \mathrm{M}\right)$ in $\mathrm{CH}_{3} \mathrm{OH}$ (solution A) which

were titrated with solutions of $\mathrm{HgCl}_{2}$ or $\mathrm{Hg}\left(\mathrm{CH}_{3} \mathrm{COO}\right)_{2}\left(5.0 \times 10^{-4} \mathrm{M}\right)$ and $\mathrm{LH}_{3}\left(1.0 \times 10^{-6}\right.$ M) in $\mathrm{CH}_{3} \mathrm{OH}$ (solution B). $2000 \mu \mathrm{L}$ of solution A was added to the fluorescence cuvette and solution B was added in increments until a total of $1000 \mu \mathrm{L}$ was added. The fluorescence intensity at $\lambda_{\max }$ of $522 \mathrm{~nm}$ was monitored.

\subsubsection{Fluorescence Titration of $\mathrm{LH}_{3}$ with $\mathrm{CaCl}_{2}, \mathrm{CdCl}_{2}, \mathrm{CoCl}_{2}, \mathrm{CuSO}_{4}$ and $\mathrm{AgCl}_{2}$}

Fluorescence emission was measured using an excitation wavelength of $350 \mathrm{~nm}$ for receptor $\mathrm{LH}_{3}$, a measurement increment of $0.5 \mathrm{~nm}$, and integration time of $0.1 \mathrm{~s}$, excitation slit width of $10 \mathrm{~nm}$, and emission slit width of $10 \mathrm{~nm} .3 \times 10^{-6} \mathrm{M}$ trimethylamine was added into the stock solution of $\mathrm{LH}_{3}$ to deprotonate the ligand when titrating with $\mathrm{HgCl}_{2}$. 
Experiments were run using solutions of $\mathrm{LH}_{3}\left(1.0 \times 10^{-6} \mathrm{M}\right)$ in $\mathrm{CH}_{3} \mathrm{OH}$ (solution A) which were titrated with solutions of $\mathrm{Ca}^{2+}, \mathrm{Cd}^{2+}, \mathrm{Cu}^{2+}, \mathrm{Ag}^{+}$, and $\mathrm{Zn}^{2+}\left(5 \times 10^{-4} \mathrm{M}\right)$ and $\mathrm{LH}_{3}(1.0$ x $10^{-6} \mathrm{M}$ ) in $\mathrm{CH}_{3} \mathrm{OH}$ (solution B). $2000 \mu \mathrm{L}$ of solution A was added to the fluorescence cuvette and solution B was added in increments until a total of $1000 \mu \mathrm{L}$ was added. The fluorescence intensity at $\lambda_{\max }$ of $522 \mathrm{~nm}$ was monitored.

\subsubsection{Competitive Experiments}

Fluorescence emission was measured using an excitation wavelength of $350 \mathrm{~nm}$ for receptor $\mathbf{L H}_{3}$, a measurement increment of $0.5 \mathrm{~nm}$, and integration time of $0.1 \mathrm{~s}$, excitation slit width of $10 \mathrm{~nm}$, and emission slit width of $10 \mathrm{~nm}$. Experiments were run using solutions of $\mathrm{LH}_{3}\left(1.0 \times 10^{-6} \mathrm{M}\right)$, trimethylamine $\left(3 \times 10^{-6} \mathrm{M}\right)$ and $\mathrm{CaCl}_{2}$ or $\left(\mathrm{Ag}^{+}, \mathrm{Co}^{2+}\right.$, and $\left.\mathrm{Ca}^{2+}\right)$ in $\mathrm{CH}_{3} \mathrm{OH}$ (solution A) which were titrated with solutions B prepared from $\mathrm{Hg}(\mathrm{II})\left(5.0 \times 10^{-4}\right.$ M) dissolved in solution A. $2000 \mu \mathrm{L}$ of solution A was added to the fluorescence cuvette and solution B was added in incrementally. The fluorescence intensity at $\lambda_{\max }$ of $522 \mathrm{~nm}$ was monitored.

\subsubsection{FTIR complexation studies of $\mathrm{LH}_{3}$ with $\mathrm{Hg}\left(\mathrm{CH}_{3} \mathrm{COO}\right)_{2}$ or $\mathrm{HgCl}_{2}$}

The FTIR of the crystal of ligand $\mathbf{L H}_{3}$ and of the crystal of $\mathrm{Hg}\left(\mathrm{LH}_{2}\right)_{2}$ were collected using the Agilent Technologies Cary 600 series FTIR spectrometer.

\subsubsection{Crystallographic data}

Single yellow prism-shaped crystals of $\mathrm{Hg}_{3}(\mathbf{L})\left(\mathrm{CH}_{3} \mathrm{COO}\right)_{3}$ were obtained by recrystallization from and acetone solution of $\mathrm{LH}_{3}$ and $\mathrm{Hg}\left(\mathrm{CH}_{3} \mathrm{COO}\right)_{2}$, while colorless crystals of $\left[\mathrm{Hg}\left(\mathbf{L H}_{2}\right)_{2}\left(\mathrm{H}_{2} \mathrm{O}\right)\right]$ were obtained by slow evaporation of a mixture of $\mathbf{L H}_{3}$, 
$\mathrm{HgCl}_{2}$ and triethylamine in a EtOH solution of the compound. A suitable crystal of $\mathrm{Hg}_{3}(\mathbf{L})\left(\mathrm{CH}_{3} \mathrm{COO}\right)_{3}(0.07 \times 0.07 \times 0.05) \mathrm{mm}^{3}$ was selected and mounted on a Bruker D8 Quest CMOS diffractometer. The crystal was kept at $T=150(2) \mathrm{K}$ during data collection. Using APEX3 ${ }^{27}$, the structure was solved with the ShelXT$^{28}$ structure solution program, using the Intrinsic Phasing solution method. The model was refined with version 2016/6 of ShelXL ${ }^{29}$ using Least Squares minimization embedded in Olex $2 .{ }^{30}$

Crystal Data. $\mathrm{C}_{58} \mathrm{H}_{70} \mathrm{Hg}_{3} \mathrm{~N}_{6} \mathrm{O}_{13} \mathrm{~S}_{3}, M_{r}=1757.15$, triclinic, $\mathrm{P}-1$ (No. 2), a = 12.9492(7) $\AA$, $\mathrm{b}=15.2503(8) \AA ̊ \Omega, \mathrm{c}=17.6699(10) \AA, \alpha=71.328(2)^{\circ}, \beta=73.826(2)^{\circ}, \gamma=85.263(2)^{\circ}$, $V=3174.9(3) \AA^{3}, T=150(2) \mathrm{K}, Z=2, Z^{\prime}=1, \mu\left(\mathrm{MoK}_{\alpha}\right)=7.399,58037$ reflections measured, 13210 unique $\left(R_{\text {int }}=0.1066\right)$ which were used in all calculations. The final $w R_{2}$ was 0.1347 (all data) and $R_{l}$ was $0.0634(\mathrm{I}>2(\mathrm{I})$ ).

Table 5.1. Crystallographic data for $\mathrm{Hg}_{3}(\mathbf{L})\left(\mathrm{CH}_{3} \mathrm{COO}\right)_{3}$

\begin{tabular}{|l|l|}
\hline Compound & $\mathrm{Hg}_{3}(\mathbf{L})\left(\mathrm{CH}_{3} \mathrm{COO}\right)_{3}$ \\
\hline & \\
\hline Formula & $\mathrm{C}_{58} \mathrm{H}_{70} \mathrm{Hg}_{3} \mathrm{~N}_{6} \mathrm{O}_{13} \mathrm{~S}_{3}$ \\
\hline$D_{\text {calc. } / \mathrm{g} \mathrm{cm}^{-3}}$ & 1.838 \\
\hline$\mu / \mathrm{mm}^{-1}$ & 7.399 \\
\hline Formula Weight & 1757.15 \\
\hline Colour & yellow \\
\hline Shape & prism \\
\hline Size $/ \mathrm{mm}^{3}$ & $0.07 \times 0.07 \times 0.05$ \\
\hline$T / \mathrm{K}$ & $150(2)$ \\
\hline Crystal System & triclinic \\
\hline Space Group & $\mathrm{P}-1$ \\
\hline$a / \AA$ & $12.9492(7)$ \\
\hline$b / \AA$ & $15.2503(8)$ \\
\hline$c / \AA$ & $17.6699(10)$ \\
\hline$\alpha /^{\circ}$ & $71.328(2)$ \\
\hline$\beta /^{\circ}$ & $73.826(2)$ \\
\hline
\end{tabular}




\begin{tabular}{|l|l|}
\hline$\gamma{ }^{\circ}$ & $85.263(2)$ \\
\hline$V / \AA^{3}$ & $3174.9(3)$ \\
\hline$Z$ & 2 \\
\hline$Z^{\prime}$ & 1 \\
\hline Wavelength/A & 0.710760 \\
\hline Radiation type & MoK $\alpha$ \\
\hline$\Theta_{\min } /^{\circ}$ & 2.917 \\
\hline$\Theta_{\max }{ }^{\circ}$ & 26.573 \\
\hline Measured Refl. & 58037 \\
\hline Independent & 13210 \\
\hline Refl. & \\
\hline Reflections Used & 7514 \\
\hline$R_{\text {int }}$ & 0.1066 \\
\hline Parameters & 792 \\
\hline Restraints & 96 \\
\hline Largest Peak & 2.405 \\
\hline Deepest Hole & -2.009 \\
\hline GooF & 1.015 \\
\hline$w R_{2}$ (all data) & 0.1347 \\
\hline$w R_{2}$ & 0.1124 \\
\hline$R_{1}$ (all data) & 0.1464 \\
\hline$R_{1}$ & 0.0634 \\
\hline
\end{tabular}

\section{Reflections: \\ Refinement:

\section{Structure Quality Indicators}

A yellow prism-shaped crystal with dimensions $0.07 \times 0.07 \times 0.05 \mathrm{~mm}^{3}$ was mounted on X-ray diffraction data were collected using a Bruker D8 Quest CMOS diffractometer equipped with a Oxford Cryostream low-temperature device, operating at $T=150(2) \mathrm{K}$. Data were measured using $\phi$ and $\omega$ scans scans of $0.50^{\circ}$ per frame for $150.00 \mathrm{~s}$ using $\mathrm{MoK}_{\alpha}$ radiation $(50 \mathrm{kV}, 30 \mathrm{~mA})$. The total number of runs and images was based on the strategy calculation from the program APEX3. The maximum resolution achieved was $\Theta=26.573^{\circ}$. 
Cell parameters were retrieved using the SAINT (Bruker, V8.37A, after 2013) software and refined using SAINT (Bruker, V8.37A, after 2013) on 9916 reflections, $17 \%$ of the observed reflections. Data reduction was performed using the SAINT (Bruker, V8.37A, after 2013) software which corrects for Lorentz polarisation. The final completeness is $99.80 \%$ out to $26.573^{\circ}$ in $\Theta$. A numerical absorption correction was performed using SADABS-2016/2 (Bruker,2016/2) was used for absorption correction. $w R_{2}$ (int) was 0.0673 before and 0.0567 after correction. The ratio of minimum to maximum transmission is 0.8384 . The $\lambda / 2$ correction factor is not present. The absorption coefficient $\mu$ of this material is $7.399 \mathrm{~mm}^{-1}$ at this wavelength $(\lambda=0.71073 \AA)$ and the minimum and maximum transmissions are 0.6609 and 0.7883 . The structure was solved in the space group P-1 (\# 2) by intrinsic phasing using the ShelXT (Sheldrick, 2015) structure solution program and refined by Least Squares using version 2016/6 of ShelXL (Sheldrick, 2015). All nonhydrogen atoms were refined anisotropically. Hydrogen atom positions were calculated geometrically and refined using the riding model. _Exptl_absorption_process_details: SADABS-2016/2 (Bruker,2016/2) was used for absorption correction. $w R_{2}$ (int) was 0.0673 before and 0.0567 after correction. The Ratio of minimum to maximum transmission is 0.8384 . The $\lambda / 2$ correction factor is not present. There is a single molecule in the asymmetric unit, which is represented by the reported sum formula. In other words: $\mathrm{Z}$ is 2 and $Z^{\prime}$ is 1 . 
Table 5.2. Fractional Atomic Coordinates $\left(\times 10^{4}\right)$ and Equivalent Isotropic Displacement Parameters $\left(\AA^{2} \times 10^{3}\right)$ for $\mathrm{Hg}_{3}(\mathbf{L})\left(\mathrm{CH}_{3} \mathrm{COO}\right)_{3}$. $U_{\text {eq }}$ is defined as $1 / 3$ of the trace of the orthogonalised $U_{i j}$.

\begin{tabular}{|c|c|c|c|c|}
\hline Atom & $\mathbf{x}$ & $\mathbf{y}$ & $\mathbf{z}$ & $U_{e q}$ \\
\hline $\mathrm{Hg} 1$ & $2087.4(3)$ & $4329.3(3)$ & $4499.2(3)$ & $32.78(13)$ \\
\hline $\mathrm{Hg} 2$ & $4478.5(4)$ & $4747.9(4)$ & $1734.1(3)$ & $48.38(16)$ \\
\hline $\mathrm{Hg} 3$ & $5011.6(4)$ & $1967.4(3)$ & $4145.5(3)$ & $47.22(16)$ \\
\hline $\mathrm{S} 1$ & $-95(2)$ & $3540.5(18)$ & $5645.7(18)$ & $38.5(8)$ \\
\hline $\mathrm{S} 2$ & $3453(2)$ & $5419(2)$ & $273.4(19)$ & $48.8(9)$ \\
\hline S3 & $5467(2)$ & $130(2)$ & $3719.4(18)$ & 46.1(9) \\
\hline $\mathrm{O} 1$ & $336(7)$ & $3898(5)$ & $6161(5)$ & $50(2)$ \\
\hline $\mathrm{O} 2$ & $-926(6)$ & $4073(5)$ & $5310(5)$ & $51(2)$ \\
\hline $\mathrm{O} 3$ & $4032(7)$ & 6193(6) & $236(6)$ & $74(3)$ \\
\hline $\mathrm{O} 4$ & $3866(7)$ & $4968(7)$ & $-346(5)$ & $74(3)$ \\
\hline $\mathrm{O5}$ & $6478(6)$ & $326(6)$ & $3826(5)$ & $55(2)$ \\
\hline O6 & $4835(6)$ & $-624(5)$ & $4349(5)$ & $61(3)$ \\
\hline $\mathrm{O} 7$ & $3522(8)$ & $3085(6)$ & $4839(7)$ & $79(3)$ \\
\hline O8 & $5199(7)$ & $2792(6)$ & $4823(6)$ & $63(3)$ \\
\hline O9 & $3229(6)$ & $5362(5)$ & $4100(5)$ & $48(2)$ \\
\hline $\mathrm{O} 10$ & $3063(7)$ & $5314(7)$ & $2918(5)$ & $67(3)$ \\
\hline O11 & $5457(9)$ & $3404(7)$ & 2761(7) & $103(4)$ \\
\hline $\mathrm{O} 12$ & $5703(7)$ & $4897(6)$ & $2210(5)$ & $64(3)$ \\
\hline N1 & $915(7)$ & $3342(6)$ & $4940(5)$ & $34(2)$ \\
\hline $\mathrm{N} 2$ & $3279(7)$ & $4706(7)$ & $1203(5)$ & $40(2)$ \\
\hline N3 & $4813(6)$ & $1078(6)$ & $3541(5)$ & $40(3)$ \\
\hline $\mathrm{C} 1$ & $1601(7)$ & 2792(7) & $3721(6)$ & $23(2)$ \\
\hline $\mathrm{C} 2$ & $2263(8)$ & 2033(7) & $3894(6)$ & $27(2)$ \\
\hline C3 & $3099(7)$ & $1866(7)$ & $3249(6)$ & $28(3)$ \\
\hline $\mathrm{C} 4$ & $3277(8)$ & $2451(7)$ & $2433(6)$ & $33(3)$ \\
\hline C5 & $2599(8)$ & $3239(7)$ & $2268(6)$ & $26(2)$ \\
\hline C6 & $1768(7)$ & $3400(7)$ & $2900(6)$ & $24(2)$ \\
\hline $\mathrm{C} 7$ & $638(8)$ & $2926(7)$ & $4386(6)$ & $34(3)$ \\
\hline $\mathrm{C} 8$ & $1051(8)$ & $4231(7)$ & $2715(6)$ & $30(3)$ \\
\hline C9 & $49(8)$ & $4025(8)$ & $2494(7)$ & $42(3)$ \\
\hline $\mathrm{C} 10$ & $2735(9)$ & $3823(8)$ & $1385(6)$ & $39(3)$ \\
\hline C11 & 4196(9) & $2276(8)$ & $1754(7)$ & $42(3)$ \\
\hline $\mathrm{C} 12$ & $3878(11)$ & $1677(10)$ & $1305(8)$ & $73(5)$ \\
\hline C13 & $3734(8)$ & $965(7)$ & $3437(7)$ & $35(3)$ \\
\hline C14 & $2077(8)$ & $1366(7)$ & $4775(6)$ & $31(3)$ \\
\hline C15 & 1318(9) & $575(8)$ & 4993(7) & $42(3)$ \\
\hline $\mathrm{C} 16$ & $-669(8)$ & $2427(7)$ & $6205(6)$ & $33(3)$ \\
\hline C17 & $-1699(9)$ & $2284(8)$ & $6228(6)$ & $41(3)$ \\
\hline
\end{tabular}




\begin{tabular}{|c|c|c|c|c|}
\hline Atom & $\mathbf{x}$ & $\begin{array}{l}\mathbf{y} \\
\end{array}$ & $\mathbf{z}$ & $U_{e q}$ \\
\hline C18 & $-2215(9)$ & 1421(8) & $6666(7)$ & $43(3)$ \\
\hline C19 & $-1645(9)$ & $716(8)$ & $7042(7)$ & $41(3)$ \\
\hline $\mathrm{C} 20$ & $-563(8)$ & $805(7)$ & $7023(6)$ & $32(3)$ \\
\hline $\mathrm{C} 21$ & $-61(8)$ & $1691(7)$ & $6631(6)$ & $31(3)$ \\
\hline $\mathrm{C} 22$ & 981(8) & $1803(7)$ & $6683(7)$ & $36(3)$ \\
\hline $\mathrm{C} 23$ & 1484(9) & $1065(8)$ & $7096(7)$ & $47(3)$ \\
\hline $\mathrm{C} 24$ & 1017(9) & $190(7)$ & $7462(7)$ & $44(3)$ \\
\hline $\mathrm{C} 25$ & $8(9)$ & $49(7)$ & $7416(7)$ & $40(3)$ \\
\hline C28 & 2141(10) & $5783(8)$ & 179(7) & $43(3)$ \\
\hline $\mathrm{C} 029$ & $42(19)$ & $7113(12)$ & $1692(14)$ & 100(7) \\
\hline C29 & $1836(10)$ & $5635(9)$ & $-444(8)$ & $52(3)$ \\
\hline $\mathrm{C} 30$ & $820(13)$ & 5942(9) & $-577(9)$ & $61(4)$ \\
\hline C31 & $158(12)$ & $6338(10)$ & $-72(11)$ & $72(5)$ \\
\hline C32 & $415(11)$ & $6506(8)$ & $603(10)$ & $57(4)$ \\
\hline C33 & $1456(10)$ & $6244(7)$ & $704(7)$ & $43(3)$ \\
\hline C34 & $1757(12)$ & $6451(8)$ & $1350(8)$ & $57(4)$ \\
\hline C35 & $1031(17)$ & $6882(10)$ & $1825(10)$ & $78(5)$ \\
\hline C36 & $-270(18)$ & $6926(12)$ & $1137(14)$ & $102(7)$ \\
\hline C39 & $5719(8)$ & $-158(8)$ & $2795(7)$ & $42(3)$ \\
\hline $\mathrm{C} 40$ & $6328(8)$ & $421(7)$ & $2007(7)$ & 33(3) \\
\hline $\mathrm{C} 41$ & $6511(9)$ & $127(8)$ & $1304(8)$ & $40(3)$ \\
\hline $\mathrm{C} 42$ & $6033(11)$ & $-720(9)$ & 1399(9) & $60(4)$ \\
\hline $\mathrm{C} 43$ & $5466(10)$ & $-1259(9)$ & $2150(9)$ & $55(4)$ \\
\hline $\mathrm{C} 44$ & $5300(9)$ & $-984(10)$ & $2849(9)$ & $63(4)$ \\
\hline $\mathrm{C} 45$ & $6804(8)$ & $1283(7)$ & 1901(7) & $34(3)$ \\
\hline $\mathrm{C} 46$ & $7432(9)$ & $1765(8)$ & $1160(7)$ & $42(3)$ \\
\hline $\mathrm{C} 47$ & $7593(11)$ & $1463(8)$ & 493(8) & $58(4)$ \\
\hline $\mathrm{C} 48$ & $7126(10)$ & 676(9) & $529(8)$ & $51(3)$ \\
\hline C51 & $5938(11)$ & $4105(12)$ & 2642(9) & $81(5)$ \\
\hline C52 & $6868(13)$ & 4101(14) & 2995(12) & $146(10)$ \\
\hline C53 & $3437(10)$ & $5671(8)$ & $3306(9)$ & $51(4)$ \\
\hline C54 & $4139(12)$ & $6518(9)$ & $2887(9)$ & $81(5)$ \\
\hline C55 & 4311(13) & $3184(9)$ & $5036(10)$ & $66(4)$ \\
\hline C56 & $4288(14)$ & 3777(11) & $5587(12)$ & $103(6)$ \\
\hline O13 & $7230(8)$ & $1870(8)$ & $3898(6)$ & $87(3)$ \\
\hline C57 & $7597(11)$ & $1926(11)$ & $4562(9)$ & $78(5)$ \\
\hline N1_1 & $-490(8)$ & $-853(6)$ & $7755(7)$ & $56(2)$ \\
\hline C1_1 & $-66(11)$ & $-1543(8)$ & $8387(8)$ & $67(3)$ \\
\hline C2_1 & $-555(11)$ & $-1243(8)$ & $7119(8)$ & $58(3)$ \\
\hline N1_2 & $-1260(50)$ & $7240(40)$ & $850(30)$ & $164(13)$ \\
\hline C1_2 & $-1380(40)$ & $8280(30)$ & $820(30)$ & $164(13)$ \\
\hline $\mathrm{C} 2 \_2$ & $-1980(30)$ & $6550(30)$ & $1120(30)$ & $167(13)$ \\
\hline N1_3 & $-1360(50)$ & $7160(50)$ & $1180(30)$ & $110(14)$ \\
\hline C1_3 & $-2160(30)$ & $7060(30)$ & $1960(30)$ & $109(15)$ \\
\hline
\end{tabular}




\begin{tabular}{|lcccc|}
\hline Atom & $\mathbf{x}$ & $\mathbf{y}$ & $\mathbf{z}$ & $\boldsymbol{U}_{\boldsymbol{e q}}$ \\
\hline C2_3 & $-1740(40)$ & $7830(40)$ & $590(30)$ & $112(15)$ \\
N1_4 & $7287(12)$ & $302(10)$ & $-152(9)$ & $94(3)$ \\
C1_4 & $6484(14)$ & $627(12)$ & $-564(11)$ & $101(4)$ \\
C2_4 & 8350(14) & $480(12)$ & $-758(10)$ & $99(4)$ \\
\hline
\end{tabular}

Table 5.3. Anisotropic Displacement Parameters $\left(\times 10^{4}\right) \mathrm{Hg}_{3}(\mathbf{L})\left(\mathrm{CH}_{3} \mathrm{COO}\right)_{3}$. The anisotropic displacement factor exponent takes the form: $-2 \pi^{2}\left[h^{2} a^{* 2} \times U_{11}+\ldots+2 h k a^{*} \times b^{*}\right.$ $\left.\times U_{12}\right]$

\begin{tabular}{|c|c|c|c|c|c|c|}
\hline \begin{tabular}{|l|} 
Atom \\
\end{tabular} & $U_{11}$ & $U_{22}$ & $U_{33}$ & $U_{23}$ & $U_{13}$ & $U_{12}$ \\
\hline $\mathrm{Hg} 1$ & $35.4(3)$ & $26.4(2)$ & $31.7(3)$ & $-2.39(19)$ & $-7.6(2)$ & $-5.77(19)$ \\
\hline $\mathrm{Hg} 2$ & $34.3(3)$ & $62.8(4)$ & $30.8(3)$ & $13.1(2)$ & $-9.6(2)$ & $-13.9(2)$ \\
\hline $\mathrm{Hg} 3$ & $31.3(3)$ & $46.2(3)$ & $46.7(3)$ & $17.0(2)$ & $-18.0(2)$ & $-5.5(2)$ \\
\hline $\mathrm{S} 1$ & $43.7(18)$ & $17.5(15)$ & $37.5(17)$ & $2.7(13)$ & $2.6(14)$ & $-0.6(13)$ \\
\hline $\mathrm{S} 2$ & $34.0(17)$ & $60(2)$ & $30.7(18)$ & $16.2(16)$ & $-7.4(14)$ & $-7.4(16)$ \\
\hline S3 & $25.8(16)$ & $47.5(19)$ & $36.5(18)$ & $18.9(14)$ & $-3.7(13)$ & $10.3(14)$ \\
\hline $\mathrm{O} 1$ & $73(6)$ & $23(4)$ & $44(5)$ & $-9(4)$ & $1(5)$ & $-11(4)$ \\
\hline $\mathrm{O} 2$ & $48(5)$ & $29(5)$ & $49(5)$ & $5(4)$ & $5(4)$ & $8(4)$ \\
\hline $\mathrm{O} 3$ & $59(6)$ & $70(7)$ & $68(7)$ & $27(5)$ & $-30(5)$ & $-24(5)$ \\
\hline $\mathrm{O} 4$ & $57(6)$ & $112(8)$ & $26(5)$ & $-1(5)$ & $3(4)$ & $11(6)$ \\
\hline O5 & $30(4)$ & $75(6)$ & $41(5)$ & $5(4)$ & $-14(4)$ & $18(4)$ \\
\hline O6 & $38(5)$ & $55(6)$ & $45(5)$ & $31(4)$ & $-1(4)$ & $9(4)$ \\
\hline $\mathrm{O} 7$ & $73(7)$ & $55(6)$ & $147(10)$ & $-44(6)$ & $-79(7)$ & $18(5)$ \\
\hline O8 & $54(6)$ & $49(6)$ & $89(7)$ & $-1(5)$ & $-46(5)$ & $-12(5)$ \\
\hline O9 & $60(6)$ & $35(5)$ & $46(5)$ & $-3(4)$ & $-15(4)$ & $-15(4)$ \\
\hline $\mathrm{O} 10$ & $62(6)$ & $83(7)$ & $48(6)$ & $-1(5)$ & $-15(5)$ & $-40(5)$ \\
\hline O11 & $99(8)$ & $75(7)$ & $114(9)$ & $58(7)$ & $-83(7)$ & $-47(7)$ \\
\hline $\mathrm{O} 12$ & $56(6)$ & $69(6)$ & $55(6)$ & $14(5)$ & $-29(5)$ & $-13(5)$ \\
\hline N1 & $40(5)$ & $25(5)$ & $26(5)$ & $2(4)$ & $-2(4)$ & $-2(4)$ \\
\hline $\mathrm{N} 2$ & $29(5)$ & $54(7)$ & $24(5)$ & $5(5)$ & $-8(4)$ & $-1(5)$ \\
\hline N3 & $20(5)$ & $49(6)$ & $28(5)$ & $16(4)$ & $-5(4)$ & $5(4)$ \\
\hline C1 & $11(5)$ & $28(6)$ & $21(5)$ & $3(5)$ & $4(4)$ & $-11(4)$ \\
\hline $\mathrm{C} 2$ & $19(5)$ & $23(6)$ & $29(6)$ & $5(5)$ & $-5(5)$ & $-9(4)$ \\
\hline C3 & $17(5)$ & $28(6)$ & $29(6)$ & $6(5)$ & $-7(5)$ & $5(5)$ \\
\hline C4 & $21(6)$ & $40(7)$ & $26(6)$ & $4(5)$ & $-5(5)$ & $-2(5)$ \\
\hline C5 & $22(5)$ & $22(6)$ & $27(6)$ & $3(5)$ & $-8(5)$ & $-3(4)$ \\
\hline C6 & $12(5)$ & $29(6)$ & $27(6)$ & $-4(5)$ & $-4(4)$ & $-2(4)$ \\
\hline C7 & $40(7)$ & $30(6)$ & $24(6)$ & $7(5)$ & $-9(5)$ & $-6(5)$ \\
\hline C8 & $25(6)$ & $39(7)$ & $18(6)$ & $-1(5)$ & $-4(5)$ & $-2(5)$ \\
\hline C9 & $32(6)$ & $55(8)$ & $37(7)$ & $-7(6)$ & $-19(5)$ & $15(6)$ \\
\hline C10 & $33(6)$ & $53(8)$ & $24(6)$ & $-3(6)$ & $-8(5)$ & $10(6)$ \\
\hline
\end{tabular}




\begin{tabular}{|c|c|c|c|c|c|c|}
\hline Atom & $U_{11}$ & $U_{22}$ & $U_{33}$ & $U_{23}$ & $U_{13}$ & $U_{12}$ \\
\hline C11 & $36(7)$ & $52(8)$ & $25(6)$ & $-1(6)$ & $-1(5)$ & $13(6)$ \\
\hline C12 & $79(11)$ & $77(11)$ & $52(9)$ & $-18(8)$ & $-9(8)$ & $36(9)$ \\
\hline C13 & $25(6)$ & $33(7)$ & $36(7)$ & $3(5)$ & $-9(5)$ & $6(5)$ \\
\hline C14 & $28(6)$ & $20(6)$ & $31(6)$ & $6(5)$ & $-1(5)$ & $-5(5)$ \\
\hline C15 & $36(7)$ & $44(7)$ & $33(7)$ & $-2(6)$ & $-1(5)$ & $-2(6)$ \\
\hline C16 & $32(6)$ & $23(6)$ & $31(6)$ & $4(5)$ & $-2(5)$ & $0(5)$ \\
\hline C17 & $40(7)$ & $40(7)$ & $26(6)$ & $1(5)$ & $0(5)$ & $12(6)$ \\
\hline C18 & $32(7)$ & $33(7)$ & $57(8)$ & $0(6)$ & $-18(6)$ & $1(5)$ \\
\hline C19 & $38(7)$ & $27(6)$ & $42(7)$ & $4(5)$ & $-4(6)$ & $-7(5)$ \\
\hline $\mathrm{C} 20$ & $26(6)$ & $29(6)$ & $29(6)$ & $0(5)$ & $4(5)$ & $-6(5)$ \\
\hline $\mathrm{C} 21$ & $29(6)$ & $28(6)$ & $24(6)$ & $3(5)$ & $1(5)$ & $-11(5)$ \\
\hline $\mathrm{C} 22$ & $32(6)$ & $21(6)$ & $47(7)$ & $-2(5)$ & $-5(6)$ & $-5(5)$ \\
\hline $\mathrm{C} 23$ & $39(7)$ & $46(8)$ & $52(8)$ & $-11(7)$ & $-12(6)$ & $9(6)$ \\
\hline $\mathrm{C} 24$ & $49(8)$ & $19(6)$ & $48(8)$ & $10(5)$ & $-16(6)$ & $9(6)$ \\
\hline $\mathrm{C} 25$ & $43(7)$ & $30(7)$ & $36(7)$ & $2(5)$ & $-6(6)$ & $-4(6)$ \\
\hline $\mathrm{C} 28$ & $52(8)$ & $37(7)$ & $30(7)$ & $10(6)$ & $-11(6)$ & $-18(6)$ \\
\hline $\mathrm{C} 029$ & $122(19)$ & $49(11)$ & $118(18)$ & $-56(12)$ & $14(15)$ & $12(11)$ \\
\hline C29 & $57(9)$ & $53(8)$ & $38(8)$ & $4(6)$ & $-16(7)$ & $-20(7)$ \\
\hline $\mathrm{C} 30$ & $82(11)$ & $52(9)$ & $61(10)$ & $1(8)$ & $-53(9)$ & $-17(8)$ \\
\hline C31 & $63(10)$ & $44(9)$ & $86(12)$ & $20(8)$ & $-34(10)$ & $11(8)$ \\
\hline C32 & $57(9)$ & $27(7)$ & $67(10)$ & $15(7)$ & $-21(8)$ & $-2(7)$ \\
\hline C33 & $66(9)$ & $23(7)$ & $26(7)$ & $8(5)$ & $-7(6)$ & $-6(6)$ \\
\hline C34 & $82(10)$ & $37(8)$ & $34(8)$ & $8(6)$ & $-8(8)$ & $-7(7)$ \\
\hline $\mathrm{C} 35$ & $120(15)$ & $55(11)$ & $50(10)$ & $-15(8)$ & $-13(11)$ & $8(11)$ \\
\hline C36 & $119(18)$ & $47(11)$ & $115(18)$ & $-24(11)$ & $-2(15)$ & $30(11)$ \\
\hline C39 & $9(5)$ & $44(8)$ & $48(8)$ & $17(6)$ & $-6(5)$ & $6(5)$ \\
\hline $\mathrm{C} 40$ & $18(5)$ & $30(7)$ & $42(7)$ & $3(5)$ & $-7(5)$ & $-3(5)$ \\
\hline C41 & $33(7)$ & $26(7)$ & $56(8)$ & $-11(6)$ & $-8(6)$ & $-2(5)$ \\
\hline $\mathrm{C} 42$ & $68(10)$ & $44(8)$ & $59(9)$ & $-9(7)$ & $-9(8)$ & $-7(7)$ \\
\hline $\mathrm{C} 43$ & $39(8)$ & $30(7)$ & $74(11)$ & $1(7)$ & $2(7)$ & $-7(6)$ \\
\hline $\mathrm{C} 44$ & $25(7)$ & $57(10)$ & $70(11)$ & $14(8)$ & $6(7)$ & $4(7)$ \\
\hline $\mathrm{C} 45$ & $28(6)$ & $29(7)$ & $39(7)$ & $-8(5)$ & $-3(5)$ & $3(5)$ \\
\hline $\mathrm{C} 46$ & $60(8)$ & $37(7)$ & $22(6)$ & $-4(6)$ & $-2(6)$ & $-7(6)$ \\
\hline $\mathrm{C} 47$ & $79(10)$ & $38(8)$ & $32(8)$ & $13(6)$ & $2(7)$ & $-23(7)$ \\
\hline $\mathrm{C} 48$ & $59(9)$ & $46(8)$ & $38(8)$ & $-4(6)$ & $1(6)$ & $-20(7)$ \\
\hline C51 & $63(10)$ & $98(13)$ & $59(10)$ & $40(9)$ & $-45(8)$ & $-41(9)$ \\
\hline $\mathrm{C} 52$ & $80(13)$ & $156(18)$ & 151(19) & $78(15)$ & $-79(13)$ & $-66(12)$ \\
\hline C53 & $42(8)$ & $33(7)$ & $67(10)$ & $7(7)$ & $-17(7)$ & $-23(6)$ \\
\hline C54 & $84(11)$ & $62(10)$ & $86(12)$ & $-2(9)$ & $-20(9)$ & $-33(9)$ \\
\hline C55 & $73(11)$ & $32(8)$ & $103(13)$ & $-3(8)$ & $-62(10)$ & $4(8)$ \\
\hline C56 & $107(14)$ & $85(13)$ & $145(17)$ & $-32(13)$ & $-87(14)$ & $8(11)$ \\
\hline 013 & $66(7)$ & $122(10)$ & $67(7)$ & $-3(7)$ & $-35(6)$ & $-9(6)$ \\
\hline C57 & $52(9)$ & $89(12)$ & $83(12)$ & $-1(9)$ & $-33(9)$ & $4(8)$ \\
\hline N1_1 & $65(5)$ & $28(5)$ & $68(6)$ & $7(4)$ & $-30(5)$ & $-6(4)$ \\
\hline
\end{tabular}




\begin{tabular}{|lcccccc|}
\hline Atom & $\boldsymbol{U}_{\mathbf{1 1}}$ & $\boldsymbol{U}_{\mathbf{2 2}}$ & $\boldsymbol{U}_{\mathbf{3 3}}$ & $\boldsymbol{U}_{\mathbf{2 3}}$ & $\boldsymbol{U}_{\mathbf{1 3}}$ & $\boldsymbol{U}_{\mathbf{1 2}}$ \\
\hline C1_1 & $76(6)$ & $36(6)$ & $76(6)$ & $13(5)$ & $-33(5)$ & $-3(5)$ \\
C2_1 & $65(6)$ & $28(5)$ & $72(6)$ & $2(4)$ & $-23(5)$ & $-8(5)$ \\
$\mathrm{N} 1 \_2$ & $160(30)$ & $160(20)$ & $220(30)$ & $-90(20)$ & $-100(20)$ & $107(19)$ \\
C1_2 & $160(30)$ & $160(20)$ & $220(30)$ & $-100(20)$ & $-100(20)$ & $107(19)$ \\
C2_2 & $160(30)$ & $160(20)$ & $220(30)$ & $-90(20)$ & $-100(20)$ & $105(19)$ \\
N1_3 & $80(20)$ & $120(30)$ & $80(20)$ & $8(18)$ & $6(15)$ & $42(18)$ \\
C1_3 & $80(20)$ & $120(30)$ & $80(20)$ & $7(18)$ & $6(15)$ & $43(18)$ \\
C2_3 & $80(20)$ & $120(30)$ & $80(20)$ & $10(18)$ & $6(15)$ & $41(18)$ \\
N1_4 & $116(9)$ & $93(7)$ & $75(8)$ & $-31(7)$ & $-19(6)$ & $-14(7)$ \\
C1_4 & $123(9)$ & $104(8)$ & $80(9)$ & $-33(7)$ & $-23(6)$ & $-9(8)$ \\
C2_4 & $121(9)$ & $94(8)$ & $78(9)$ & $-31(7)$ & $-13(6)$ & $-8(8)$ \\
\hline
\end{tabular}

Table 5.4. Bond Lengths in $\AA$ for $\mathrm{Hg}_{3}(\mathbf{L})\left(\mathrm{CH}_{3} \mathrm{COO}\right)_{3}$.

\begin{tabular}{|lll|}
\hline Atom & Atom & Length/A \\
\hline $\mathrm{Hg} 1$ & $\mathrm{O} 7$ & $2.593(8)$ \\
$\mathrm{Hg} 1$ & $\mathrm{O} 9$ & $2.064(7)$ \\
$\mathrm{Hg} 1$ & $\mathrm{~N} 1$ & $2.036(8)$ \\
$\mathrm{Hg} 1$ & $\mathrm{C} 53$ & $2.731(12)$ \\
$\mathrm{Hg} 2$ & $\mathrm{O} 12$ & $2.049(8)$ \\
$\mathrm{Hg} 2$ & $\mathrm{~N} 2$ & $2.041(9)$ \\
$\mathrm{Hg} 2$ & $\mathrm{C} 51$ & $2.735(12)$ \\
$\mathrm{Hg} 3$ & $\mathrm{O} 8$ & $2.061(9)$ \\
$\mathrm{Hg} 3$ & $\mathrm{~N} 3$ & $2.045(10)$ \\
$\mathrm{Hg} 3$ & $\mathrm{C} 55$ & $2.746(17)$ \\
$\mathrm{S} 1$ & $\mathrm{O} 1$ & $1.445(8)$ \\
$\mathrm{S} 1$ & $\mathrm{O} 2$ & $1.439(8)$ \\
$\mathrm{S} 1$ & $\mathrm{~N} 1$ & $1.620(9)$ \\
$\mathrm{S} 1$ & $\mathrm{C} 16$ & $1.771(10)$ \\
$\mathrm{S} 2$ & $\mathrm{O} 3$ & $1.425(9)$ \\
$\mathrm{S} 2$ & $\mathrm{O} 4$ & $1.432(10)$ \\
$\mathrm{S} 2$ & $\mathrm{~N} 2$ & $1.619(9)$ \\
$\mathrm{S} 2$ & $\mathrm{C} 28$ & $1.779(12)$ \\
$\mathrm{S} 3$ & $\mathrm{O} 5$ & $1.441(8)$ \\
$\mathrm{S} 3$ & $\mathrm{O} 6$ & $1.435(8)$ \\
S3 & $\mathrm{N} 3$ & $1.602(9)$ \\
S3 & $\mathrm{C} 39$ & $1.762(13)$ \\
$\mathrm{O} 7$ & $\mathrm{C} 55$ & $1.202(14)$ \\
O8 & $\mathrm{C} 55$ & $1.270(16)$ \\
$\mathrm{O} 9$ & $\mathrm{C} 53$ & $1.284(15)$ \\
$\mathrm{O} 10$ & $\mathrm{C} 53$ & $1.212(14)$ \\
$\mathrm{O} 11$ & $\mathrm{C} 51$ & $1.212(16)$ \\
& &
\end{tabular}




\begin{tabular}{|c|c|c|}
\hline $\mathrm{O} 12$ & C51 & $1.269(16)$ \\
\hline N1 & $\mathrm{C} 7$ & $1.456(13)$ \\
\hline $\mathrm{N} 2$ & $\mathrm{C} 10$ & $1.473(14)$ \\
\hline N3 & $\mathrm{C} 13$ & $1.490(12)$ \\
\hline $\mathrm{C} 1$ & $\mathrm{C} 2$ & $1.387(13)$ \\
\hline $\mathrm{C} 1$ & C6 & $1.417(13)$ \\
\hline $\mathrm{C} 1$ & $\mathrm{C} 7$ & $1.507(13)$ \\
\hline $\mathrm{C} 2$ & $\mathrm{C} 3$ & $1.410(14)$ \\
\hline $\mathrm{C} 2$ & C14 & $1.529(13)$ \\
\hline C3 & $\mathrm{C} 4$ & $1.397(13)$ \\
\hline C3 & C13 & $1.533(13)$ \\
\hline $\mathrm{C} 4$ & $\mathrm{C} 5$ & $1.429(13)$ \\
\hline $\mathrm{C} 4$ & $\mathrm{C} 11$ & $1.511(14)$ \\
\hline $\mathrm{C} 5$ & C6 & $1.389(13)$ \\
\hline C5 & $\mathrm{C} 10$ & $1.496(13)$ \\
\hline C6 & $\mathrm{C} 8$ & $1.511(13)$ \\
\hline $\mathrm{C} 8$ & C9 & $1.537(13)$ \\
\hline C11 & C12 & $1.530(17)$ \\
\hline $\mathrm{C} 14$ & C15 & $1.503(13)$ \\
\hline $\mathrm{C} 16$ & C17 & $1.356(14)$ \\
\hline $\mathrm{C} 16$ & $\mathrm{C} 21$ & $1.446(14)$ \\
\hline $\mathrm{C} 17$ & $\mathrm{C} 18$ & $1.408(14)$ \\
\hline C18 & C19 & $1.352(14)$ \\
\hline C19 & $\mathrm{C} 20$ & $1.408(14)$ \\
\hline $\mathrm{C} 20$ & $\mathrm{C} 21$ & $1.422(13)$ \\
\hline $\mathrm{C} 20$ & $\mathrm{C} 25$ & $1.411(14)$ \\
\hline $\mathrm{C} 21$ & $\mathrm{C} 22$ & $1.406(14)$ \\
\hline $\mathrm{C} 22$ & $\mathrm{C} 23$ & $1.357(14)$ \\
\hline $\mathrm{C} 23$ & $\mathrm{C} 24$ & $1.388(15)$ \\
\hline $\mathrm{C} 24$ & $\mathrm{C} 25$ & $1.369(15)$ \\
\hline $\mathrm{C} 25$ & N1_1 & $1.439(13)$ \\
\hline $\mathrm{C} 28$ & $\mathrm{C} 2 \overline{9}$ & $1.354(16)$ \\
\hline C28 & C33 & $1.413(16)$ \\
\hline $\mathrm{C} 029$ & $\mathrm{C} 35$ & $1.36(2)$ \\
\hline $\mathrm{CO} 29$ & $\mathrm{C} 36$ & $1.27(3)$ \\
\hline C29 & $\mathrm{C} 30$ & $1.417(18)$ \\
\hline $\mathrm{C} 30$ & C31 & $1.315(19)$ \\
\hline C31 & C32 & $1.43(2)$ \\
\hline C32 & C33 & $1.417(17)$ \\
\hline C32 & C36 & $1.38(2)$ \\
\hline C33 & C34 & $1.432(17)$ \\
\hline C34 & C35 & $1.354(19)$ \\
\hline C36 & N1_2 & $1.50(5)$ \\
\hline C36 & N1_3 & $1.41(7)$ \\
\hline C39 & $\mathrm{C} 40$ & $1.434(14)$ \\
\hline
\end{tabular}




\begin{tabular}{|lll|}
$\mathrm{C} 39$ & $\mathrm{C} 44$ & $1.378(17)$ \\
$\mathrm{C} 40$ & $\mathrm{C} 41$ & $1.405(15)$ \\
$\mathrm{C} 40$ & $\mathrm{C} 45$ & $1.434(14)$ \\
$\mathrm{C} 41$ & $\mathrm{C} 42$ & $1.420(16)$ \\
$\mathrm{C} 41$ & $\mathrm{C} 48$ & $1.406(15)$ \\
$\mathrm{C} 42$ & $\mathrm{C} 43$ & $1.355(17)$ \\
$\mathrm{C} 43$ & $\mathrm{C} 44$ & $1.385(18)$ \\
$\mathrm{C} 45$ & $\mathrm{C} 46$ & $1.344(14)$ \\
$\mathrm{C} 46$ & $\mathrm{C} 47$ & $1.357(16)$ \\
$\mathrm{C} 47$ & $\mathrm{C} 48$ & $1.364(16)$ \\
$\mathrm{C} 48$ & $\mathrm{~N} 1 \_4$ & $1.448(17)$ \\
$\mathrm{C} 51$ & $\mathrm{C} 52$ & $1.501(18)$ \\
$\mathrm{C} 53$ & $\mathrm{C} 54$ & $1.500(16)$ \\
$\mathrm{C} 55$ & $\mathrm{C} 56$ & $1.52(2)$ \\
$\mathrm{O} 13$ & $\mathrm{C} 57$ & $1.411(15)$ \\
$\mathrm{N} 1 \_1$ & $\mathrm{C} 1 \_1$ & $1.466(14)$ \\
$\mathrm{N} 1 \_1$ & $\mathrm{C} 2 \_1$ & $1.453(15)$ \\
$\mathrm{N} 1 \_2$ & $\mathrm{C} 1 \_2$ & $1.56(7)$ \\
$\mathrm{N} 1 \_2$ & $\mathrm{C} 2 \_2$ & $1.34(7)$ \\
$\mathrm{N} 1 \_3$ & $\mathrm{C} 1 \_3$ & $1.44(6)$ \\
$\mathrm{N} 1 \_3$ & $\mathrm{C} 2 \_3$ & $1.38(8)$ \\
$\mathrm{N} 1 \_4$ & $\mathrm{C} 1 \_4$ & $1.402(19)$ \\
$\mathrm{N} 1 \_4$ & $\mathrm{C} 2 \_4$ & $1.473(19)$ \\
\hline
\end{tabular}

Table 5.5. Bond Angles in ${ }^{\circ}$ for $\mathrm{Hg}_{3}(\mathbf{L})\left(\mathrm{CH}_{3} \mathrm{COO}\right)_{3}$

\begin{tabular}{|llll|}
\hline Atom & Atom & Atom & Angle $^{\circ}$ \\
\hline O7 & Hg1 & C53 & $98.0(4)$ \\
O9 & Hg1 & O7 & $90.5(3)$ \\
O9 & Hg1 & C53 & $26.7(4)$ \\
N1 & Hg1 & O7 & $91.1(3)$ \\
N1 & Hg1 & O9 & $176.9(3)$ \\
N1 & Hg1 & C53 & $155.3(4)$ \\
O12 & Hg2 & C51 & $26.1(4)$ \\
N2 & Hg2 & O12 & $175.5(4)$ \\
N2 & Hg2 & C51 & $158.4(4)$ \\
O8 & Hg3 & C55 & $26.0(3)$ \\
N3 & Hg3 & O8 & $176.3(3)$ \\
N3 & Hg3 & C55 & $154.3(4)$ \\
O1 & S1 & N1 & $107.2(5)$ \\
O1 & S1 & C16 & $110.8(5)$ \\
O2 & S1 & O1 & $116.9(5)$ \\
O2 & S1 & N1 & $112.9(5)$
\end{tabular}




\begin{tabular}{|c|c|c|c|}
\hline Atom & Atom & Atom & Angle $/^{\circ}$ \\
\hline $\mathrm{O} 2$ & S1 & C16 & $105.0(5)$ \\
\hline N1 & $\mathrm{S} 1$ & $\mathrm{C} 16$ & $103.2(5)$ \\
\hline O3 & $\mathrm{S} 2$ & $\mathrm{O} 4$ & $118.2(6)$ \\
\hline O3 & $\mathrm{S} 2$ & $\mathrm{~N} 2$ & $106.6(5)$ \\
\hline $\mathrm{O} 3$ & $\mathrm{~S} 2$ & C28 & $108.8(6)$ \\
\hline O4 & $\mathrm{S} 2$ & $\mathrm{~N} 2$ & $112.2(5)$ \\
\hline O4 & $\mathrm{S} 2$ & $\mathrm{C} 28$ & $104.8(6)$ \\
\hline $\mathrm{N} 2$ & $\mathrm{~S} 2$ & $\mathrm{C} 28$ & $105.5(5)$ \\
\hline O5 & S3 & N3 & $107.7(5)$ \\
\hline $\mathrm{O5}$ & S3 & C39 & $108.7(5)$ \\
\hline O6 & S3 & $\mathrm{O} 5$ & $117.4(5)$ \\
\hline O6 & S3 & N3 & $113.0(4)$ \\
\hline O6 & S3 & C39 & $105.2(6)$ \\
\hline N3 & S3 & C39 & $104.0(5)$ \\
\hline C55 & $\mathrm{O} 7$ & $\mathrm{Hg} 1$ & 126.4(9) \\
\hline C55 & $\mathrm{O} 8$ & $\mathrm{Hg} 3$ & $108.7(8)$ \\
\hline C53 & O9 & $\mathrm{Hg} 1$ & $107.0(7)$ \\
\hline C51 & $\mathrm{O} 12$ & $\mathrm{Hg} 2$ & $108.7(8)$ \\
\hline $\mathrm{S} 1$ & $\mathrm{~N} 1$ & $\mathrm{Hg} 1$ & $113.0(5)$ \\
\hline $\mathrm{C7}$ & N1 & $\mathrm{Hg} 1$ & $120.6(6)$ \\
\hline C7 & N1 & $\mathrm{S} 1$ & 115.1(7) \\
\hline $\mathrm{S} 2$ & $\mathrm{~N} 2$ & $\mathrm{Hg} 2$ & $113.9(5)$ \\
\hline $\mathrm{C} 10$ & $\mathrm{~N} 2$ & $\mathrm{Hg} 2$ & $119.9(6)$ \\
\hline C10 & $\mathrm{N} 2$ & $\mathrm{~S} 2$ & $116.9(7)$ \\
\hline S3 & N3 & $\mathrm{Hg} 3$ & $115.8(5)$ \\
\hline C13 & N3 & $\mathrm{Hg} 3$ & 119.9(7) \\
\hline C13 & N3 & S3 & 113.1(7) \\
\hline $\mathrm{C} 2$ & $\mathrm{C} 1$ & C6 & 120.1(9) \\
\hline $\mathrm{C} 2$ & $\mathrm{C} 1$ & $\mathrm{C} 7$ & $120.3(8)$ \\
\hline C6 & $\mathrm{C} 1$ & $\mathrm{C} 7$ & 119.4(8) \\
\hline $\mathrm{C} 1$ & $\mathrm{C} 2$ & $\mathrm{C} 3$ & 119.8(9) \\
\hline $\mathrm{C} 1$ & $\mathrm{C} 2$ & $\mathrm{C} 14$ & 120.3(9) \\
\hline C3 & $\mathrm{C} 2$ & C14 & 119.9(9) \\
\hline $\mathrm{C} 2$ & C3 & $\mathrm{C} 13$ & $118.6(9)$ \\
\hline $\mathrm{C} 4$ & $\mathrm{C} 3$ & $\mathrm{C} 2$ & 121.3(9) \\
\hline $\mathrm{C} 4$ & C3 & $\mathrm{C} 13$ & 119.7(9) \\
\hline C3 & $\mathrm{C} 4$ & $\mathrm{C} 5$ & 118.2(9) \\
\hline C3 & $\mathrm{C} 4$ & C11 & $120.5(9)$ \\
\hline $\mathrm{C} 5$ & $\mathrm{C} 4$ & C11 & 121.2(9) \\
\hline C4 & $\mathrm{C} 5$ & $\mathrm{C} 10$ & 118.1(9) \\
\hline C6 & $\mathrm{C} 5$ & $\mathrm{C} 4$ & $120.6(9)$ \\
\hline C6 & $\mathrm{C} 5$ & $\mathrm{C} 10$ & $121.0(9)$ \\
\hline $\mathrm{C} 1$ & C6 & $\mathrm{C} 8$ & 120.0(9) \\
\hline $\mathrm{C} 5$ & C6 & $\mathrm{C} 1$ & $120.0(9)$ \\
\hline
\end{tabular}




\begin{tabular}{|c|c|c|c|}
\hline Atom & Atom & Atom & Angle $/^{\circ}$ \\
\hline$\overline{\mathrm{C} 5}$ & C6 & $\mathrm{C} 8$ & $120.0(9)$ \\
\hline N1 & $\mathrm{C} 7$ & $\mathrm{C} 1$ & $112.9(8)$ \\
\hline C6 & $\mathrm{C} 8$ & C9 & $113.2(9)$ \\
\hline $\mathrm{N} 2$ & $\mathrm{C} 10$ & $\mathrm{C} 5$ & $111.6(9)$ \\
\hline $\mathrm{C} 4$ & C11 & $\mathrm{C} 12$ & $113.4(10)$ \\
\hline N3 & C13 & $\mathrm{C} 3$ & $114.2(9)$ \\
\hline C15 & C14 & $\mathrm{C} 2$ & $115.5(9)$ \\
\hline C17 & $\mathrm{C} 16$ & $\mathrm{~S} 1$ & 118.2(8) \\
\hline C17 & C16 & $\mathrm{C} 21$ & $120.7(9)$ \\
\hline $\mathrm{C} 21$ & $\mathrm{C} 16$ & $\mathrm{~S} 1$ & $121.1(8)$ \\
\hline C16 & $\mathrm{C} 17$ & C18 & $121.6(10)$ \\
\hline C19 & $\mathrm{C} 18$ & $\mathrm{C} 17$ & $118.4(10)$ \\
\hline C18 & C19 & $\mathrm{C} 20$ & $123.2(10)$ \\
\hline C19 & $\mathrm{C} 20$ & $\mathrm{C} 21$ & $118.6(9)$ \\
\hline C19 & $\mathrm{C} 20$ & $\mathrm{C} 25$ & $121.5(10)$ \\
\hline $\mathrm{C} 25$ & $\mathrm{C} 20$ & $\mathrm{C} 21$ & $119.8(10)$ \\
\hline $\mathrm{C} 20$ & $\mathrm{C} 21$ & $\mathrm{C} 16$ & 117.2(9) \\
\hline $\mathrm{C} 22$ & $\mathrm{C} 21$ & $\mathrm{C} 16$ & $124.0(9)$ \\
\hline $\mathrm{C} 22$ & $\mathrm{C} 21$ & $\mathrm{C} 20$ & 118.8(9) \\
\hline $\mathrm{C} 23$ & $\mathrm{C} 22$ & $\mathrm{C} 21$ & $119.3(10)$ \\
\hline $\mathrm{C} 22$ & $\mathrm{C} 23$ & $\mathrm{C} 24$ & $122.6(11)$ \\
\hline $\mathrm{C} 25$ & $\mathrm{C} 24$ & $\mathrm{C} 23$ & $119.9(10)$ \\
\hline $\mathrm{C} 20$ & $\mathrm{C} 25$ & N1_1 & $118.6(10)$ \\
\hline $\mathrm{C} 24$ & $\mathrm{C} 25$ & $\mathrm{C} 20$ & $119.5(10)$ \\
\hline $\mathrm{C} 24$ & $\mathrm{C} 25$ & N1_1 & $121.9(10)$ \\
\hline $\mathrm{C} 29$ & C28 & $\mathrm{S} 2$ & $117.1(11)$ \\
\hline $\mathrm{C} 29$ & $\mathrm{C} 28$ & C33 & $120.8(12)$ \\
\hline C33 & $\mathrm{C} 28$ & $\mathrm{~S} 2$ & $122.0(9)$ \\
\hline $\mathrm{C} 36$ & $\mathrm{C} 029$ & C35 & $123(2)$ \\
\hline $\mathrm{C} 28$ & C29 & C30 & $120.2(14)$ \\
\hline C31 & C30 & $\mathrm{C} 29$ & $119.6(13)$ \\
\hline $\mathrm{C} 30$ & C31 & C32 & $123.4(14)$ \\
\hline C33 & C32 & C31 & $116.6(14)$ \\
\hline C36 & C32 & C31 & $124.1(17)$ \\
\hline C36 & C32 & C33 & $119.3(16)$ \\
\hline $\mathrm{C} 28$ & C33 & C32 & $119.2(13)$ \\
\hline $\mathrm{C} 28$ & C33 & C34 & $123.0(12)$ \\
\hline C32 & C33 & C34 & $117.7(13)$ \\
\hline C35 & C34 & C33 & $118.1(14)$ \\
\hline C34 & C35 & $\mathrm{C} 029$ & $120.9(17)$ \\
\hline C029 & C36 & C32 & $121(2)$ \\
\hline $\mathrm{C} 029$ & C36 & N1_2 & $129(3)$ \\
\hline $\mathrm{C} 029$ & C36 & N1_3 & $112(4)$ \\
\hline C32 & C36 & N1_2 & $110(3)$ \\
\hline
\end{tabular}




\begin{tabular}{|c|c|c|c|}
\hline Atom & Atom & Atom & Angle/ ${ }^{\circ}$ \\
\hline$\overline{\mathrm{C} 32}$ & C36 & N1_3 & $128(4)$ \\
\hline $\mathrm{C} 40$ & C39 & S3 & $123.3(10)$ \\
\hline $\mathrm{C} 44$ & C39 & S3 & $117.1(10)$ \\
\hline $\mathrm{C} 44$ & C39 & $\mathrm{C} 40$ & $119.6(12)$ \\
\hline C39 & $\mathrm{C} 40$ & $\mathrm{C} 45$ & $122.9(11)$ \\
\hline C41 & $\mathrm{C} 40$ & C39 & $119.5(11)$ \\
\hline C41 & $\mathrm{C} 40$ & $\mathrm{C} 45$ & $117.5(10)$ \\
\hline $\mathrm{C} 40$ & $\mathrm{C} 41$ & $\mathrm{C} 42$ & $118.0(11)$ \\
\hline $\mathrm{C} 40$ & C41 & $\mathrm{C} 48$ & $120.4(11)$ \\
\hline $\mathrm{C} 48$ & C41 & $\mathrm{C} 42$ & $121.6(12)$ \\
\hline $\mathrm{C} 43$ & $\mathrm{C} 42$ & $\mathrm{C} 41$ & $121.5(13)$ \\
\hline $\mathrm{C} 42$ & $\mathrm{C} 43$ & $\mathrm{C} 44$ & $120.8(13)$ \\
\hline C39 & $\mathrm{C} 44$ & $\mathrm{C} 43$ & $120.5(12)$ \\
\hline $\mathrm{C} 46$ & $\mathrm{C} 45$ & $\mathrm{C} 40$ & $120.4(11)$ \\
\hline $\mathrm{C} 45$ & $\mathrm{C} 46$ & $\mathrm{C} 47$ & $120.7(12)$ \\
\hline $\mathrm{C} 46$ & $\mathrm{C} 47$ & $\mathrm{C} 48$ & $122.7(11)$ \\
\hline C41 & $\mathrm{C} 48$ & N1_4 & $116.1(12)$ \\
\hline C47 & $\mathrm{C} 48$ & $\mathrm{C} 41$ & $118.2(12)$ \\
\hline C47 & $\mathrm{C} 48$ & N1_4 & $125.5(12)$ \\
\hline O11 & C51 & $\mathrm{Hg} \overline{2}$ & $78.0(7)$ \\
\hline O11 & C51 & $\mathrm{O} 12$ & $123.1(12)$ \\
\hline O11 & C51 & C52 & $122.2(14)$ \\
\hline $\mathrm{O} 12$ & C51 & $\mathrm{Hg} 2$ & $45.2(6)$ \\
\hline O12 & C51 & C52 & $114.7(14)$ \\
\hline C52 & C51 & $\mathrm{Hg} 2$ & $159.7(12)$ \\
\hline O9 & C53 & $\mathrm{Hg} 1$ & $46.3(5)$ \\
\hline O9 & C53 & C54 & $116.3(13)$ \\
\hline $\mathrm{O} 10$ & C53 & $\mathrm{Hg} 1$ & $75.9(7)$ \\
\hline $\mathrm{O} 10$ & $\mathrm{C} 53$ & O9 & $122.0(11)$ \\
\hline $\mathrm{O} 10$ & C53 & C54 & $121.7(13)$ \\
\hline C54 & C53 & Hg1 & $161.3(11)$ \\
\hline O7 & C55 & $\mathrm{Hg} 3$ & $78.0(9)$ \\
\hline O7 & C55 & $\mathrm{O} 8$ & $123.3(15)$ \\
\hline O7 & C55 & C56 & $121.1(15)$ \\
\hline O8 & C55 & $\mathrm{Hg} 3$ & $45.3(7)$ \\
\hline O8 & C55 & C56 & $115.6(13)$ \\
\hline C56 & C55 & $\mathrm{Hg} 3$ & $160.7(10)$ \\
\hline $\mathrm{C} 25$ & N1_1 & $\mathrm{C} 1 \_1$ & $116.8(10)$ \\
\hline $\mathrm{C} 25$ & N1_1 & $\mathrm{C} 2 \_1$ & $112.8(10)$ \\
\hline C2_1 & N1_1 & C1_1 & $110.0(10)$ \\
\hline C36 & N1_2 & C1_2 & $105(4)$ \\
\hline C2_2 & N1_2 & C36 & 111(4) \\
\hline C2_2 & N1_2 & C1_2 & $132(5)$ \\
\hline C36 & N1_3 & C1_3 & $123(5)$ \\
\hline
\end{tabular}




\begin{tabular}{|llll|}
\hline Atom & Atom & Atom & \multicolumn{1}{c|}{ Angle/ $^{\circ}$} \\
\hline C2_3 & N1_3 & C36 & $126(4)$ \\
C2_3 & N1_3 & C1_3 & $106(5)$ \\
C48 & N1_4 & C2_4 & $115.8(13)$ \\
C1_4 & N1_4 & C48 & $109.6(14)$ \\
C1_4 & N1_4 & C2_4 & $109.4(14)$ \\
\hline
\end{tabular}

Table 5.6. Hydrogen Fractional Atomic Coordinates $\left(\times 10^{4}\right)$ and Equivalent Isotropic Displacement Parameters $\left(\AA^{2} \times 10^{3}\right) \mathrm{Hg}_{3}(\mathbf{L})\left(\mathrm{CH}_{3} \mathrm{COO}\right)_{3}$. U $U_{\text {eq }}$ is defined as $1 / 3$ of the trace of the orthogonalised $U_{i j}$.

\begin{tabular}{|c|c|c|c|c|}
\hline Atom & $\mathbf{x}$ & $\mathbf{y}$ & $\mathbf{Z}$ & $U_{e q}$ \\
\hline H7A & 113.05 & 3326 & 4120.83 & 41 \\
\hline H7B & 288.46 & 2318.33 & 4715.66 & 41 \\
\hline H8A & 1470.61 & 4734.84 & 2246.98 & 36 \\
\hline H8B & 819.51 & 4453.49 & 3204.51 & 36 \\
\hline H9A & 259.66 & 3684.01 & 2089.62 & 63 \\
\hline H9B & -290.63 & 4607.96 & 2255.33 & 63 \\
\hline H9C & -461.34 & 3650.71 & 2995.8 & 63 \\
\hline H10A & 3161.09 & 3479.2 & 1014.02 & 47 \\
\hline H10B & 2019.99 & 3948.5 & 1274.19 & 47 \\
\hline H11A & 4783.74 & 1966.33 & 1998.28 & 51 \\
\hline H11B & 4476.82 & 2877.01 & 1345.05 & 51 \\
\hline $\mathrm{H} 12 \mathrm{~A}$ & 4487.15 & 1634.81 & 842.87 & 110 \\
\hline H12B & 3265.63 & 1957.93 & 1092.43 & 110 \\
\hline $\mathrm{H} 12 \mathrm{C}$ & 3677.28 & 1056.01 & 1692.8 & 110 \\
\hline H13A & 3308.06 & 517.27 & 3950.09 & 42 \\
\hline H13B & 3827.07 & 698.01 & 2979.69 & 42 \\
\hline H14A & 2779.13 & 1108.64 & 4856.85 & 37 \\
\hline H14B & 1794.82 & 1722.99 & 5168.71 & 37 \\
\hline $\mathrm{H} 15 \mathrm{~A}$ & 1604.58 & 194.4 & 4628.38 & 63 \\
\hline H15B & 614.46 & 817.86 & 4922.04 & 63 \\
\hline $\mathrm{H} 15 \mathrm{C}$ & 1238.83 & 196.07 & 5570.9 & 63 \\
\hline H17 & -2081.44 & 2778.59 & 5942.48 & 49 \\
\hline H18 & -2945.45 & 1336.43 & 6696.1 & 51 \\
\hline H19 & -1990.82 & 132.54 & 7334.14 & 49 \\
\hline $\mathrm{H} 22$ & 1329.93 & 2389.75 & 6431.75 & 43 \\
\hline $\mathrm{H} 23$ & 2182.99 & 1149.92 & 7136.23 & 56 \\
\hline $\mathrm{H} 24$ & 1397.19 & -310.13 & 7743.38 & 53 \\
\hline H029 & -439.14 & 7427.82 & 2029.83 & 119 \\
\hline $\mathrm{H} 29$ & 2305.02 & 5324.28 & -791.76 & 63 \\
\hline H30 & 618.16 & 5862.96 & -1028.58 & 73 \\
\hline H31 & -528.76 & 6521.61 & -161.8 & 86 \\
\hline
\end{tabular}




\begin{tabular}{|c|c|c|c|c|}
\hline H34 & 2446.76 & 6290.94 & 1441.42 & 68 \\
\hline H35 & 1213.28 & 7026 & 2256.83 & 94 \\
\hline H42 & 6113.21 & -912.53 & 925.23 & 72 \\
\hline H43 & 5177.96 & -1833.78 & 2197.38 & 67 \\
\hline H44 & 4893.55 & -1367.76 & 3370.03 & 75 \\
\hline H45 & 6675.49 & 1515.05 & 2358.22 & 41 \\
\hline H46 & 7765.68 & 2323.5 & 1102.14 & 51 \\
\hline H47 & 8050.58 & 1813.95 & -20.69 & 69 \\
\hline H52A & 7241.03 & 4699.88 & 2733.71 & 175 \\
\hline H52B & 7367.11 & 3608.29 & 2888.65 & 175 \\
\hline H52C & 6601.46 & 3991.1 & 3594.49 & 175 \\
\hline H54A & 4078.91 & 6868.21 & 3275.49 & 97 \\
\hline H54B & 3908.03 & 6905.95 & 2402.85 & 97 \\
\hline H54C & 4887.6 & 6333.45 & 2709.08 & 97 \\
\hline H56A & 4068.12 & 3396.07 & 6169.59 & 123 \\
\hline H56B & 3774.81 & 4282.31 & 5484.2 & 123 \\
\hline H56C & 5006.36 & 4036.3 & 5461.8 & 123 \\
\hline H13 & 7587.32 & 2237.47 & 3451.77 & 131 \\
\hline H57A & 8376.56 & 1831.06 & 4441.19 & 94 \\
\hline H57B & 7239.41 & 1448.49 & 5071.38 & 94 \\
\hline H57C & 7431.45 & 2538.37 & 4632.92 & 94 \\
\hline H1A_1 & 647.24 & -1739.29 & 8126.1 & 81 \\
\hline H1B_1 & -551.65 & -2080.08 & 8649.39 & 81 \\
\hline $\mathrm{H} 1 \mathrm{C} \_1$ & -10.77 & -1271.07 & 8806.8 & 81 \\
\hline H2A_1 & -777.26 & -762.37 & 6673.8 & 69 \\
\hline H2B_1 & -1083.1 & -1750.18 & 7361.46 & 69 \\
\hline $\mathrm{H} 2 \mathrm{C}_{-} 1$ & 150.51 & -1480.22 & 6892.03 & 69 \\
\hline H1A_2 & -1517.56 & 8325.93 & 1376.33 & 197 \\
\hline H1B_2 & -1984.95 & 8551.16 & 586.55 & 197 \\
\hline $\mathrm{H} 1 \mathrm{C} \_2$ & -718.43 & 8617.6 & 462.55 & 197 \\
\hline H2A_2 & -1613.67 & 5995.45 & 1008.65 & 200 \\
\hline H2B_2 & -2541.96 & 6729.39 & 829.29 & 200 \\
\hline $\mathrm{H} 2 \mathrm{C} \_2$ & -2297.93 & 6414.16 & 1717.27 & 200 \\
\hline H1A_3 & -1954.35 & 6545.4 & 2394.06 & 130 \\
\hline H1B_3 & -2854.88 & 6919.53 & 1906.94 & 130 \\
\hline $\mathrm{H} 1 \mathrm{C}_{-} 3$ & -2199.8 & 7629.88 & 2100.6 & 130 \\
\hline H2A_3 & -1864.76 & 8399.16 & 745.8 & 134 \\
\hline H2B_3 & -2412.08 & 7614.56 & 560.61 & 134 \\
\hline $\mathrm{H} 2 \mathrm{C} \_3$ & -1205.34 & 7946.78 & 53.87 & 134 \\
\hline H1A_4 & 5783.01 & 575.98 & -155.74 & 122 \\
\hline H1B_4 & 6476.51 & 255.38 & -923.88 & 122 \\
\hline $\mathrm{H} 1 \mathrm{C}_{-} 4$ & 6629.5 & 1275.86 & -899.78 & 122 \\
\hline $\mathrm{H} 2 \mathrm{~A} \_4$ & 8426.37 & 1142.38 & -1067.23 & 119 \\
\hline H2B_4 & 8415.73 & 125.97 & -1144.27 & 119 \\
\hline $\mathrm{H} 2 \mathrm{C} \_4$ & 8913.53 & 291.92 & -467.25 & 119 \\
\hline
\end{tabular}


Table 5.7. Atomic occupancies for all atoms that are not fully occupied in $\mathrm{Hg}_{3}(\mathbf{L})\left(\mathrm{CH}_{3} \mathrm{COO}\right)_{3}$

\begin{tabular}{|l|r|}
\hline Atom & Occupancy \\
\hline N1_2 & $0.61(3)$ \\
\hline C1_2 & $0.61(3)$ \\
\hline H1A_2 & $0.61(3)$ \\
\hline H1B_2 & $0.61(3)$ \\
\hline H1C_2 & $0.61(3)$ \\
\hline C2_2 & $0.61(3)$ \\
\hline H2A_2 & $0.61(3)$ \\
\hline H2B_2 & $0.61(3)$ \\
\hline H2C_2 & $0.61(3)$ \\
\hline N1_3 & $0.39(3)$ \\
\hline C1_3 & $0.39(3)$ \\
\hline H1A_3 & $0.39(3)$ \\
\hline H1B_3 & $0.39(3)$ \\
\hline H1C_3 & $0.39(3)$ \\
\hline C2_3 & $0.39(3)$ \\
\hline H2A_3 & $0.39(3)$ \\
\hline H2B_3 & $0.39(3)$ \\
\hline H2C_3 & $0.39(3)$ \\
\hline
\end{tabular}


Table 5.8. Crystal data and structure refinement for $\left[\mathrm{Hg}\left(\mathbf{L} . \mathrm{H}_{2}\right)_{2}\left(\mathrm{H}_{2} \mathrm{O}\right)\right]$

\begin{tabular}{|c|c|}
\hline Identification code & {$\left[\mathrm{Hg}\left(\mathbf{L} \cdot \mathrm{H}_{2}\right)_{2}\left(\mathrm{H}_{2} \mathrm{O}\right)\right]$} \\
\hline Empirical formula & $\mathrm{C}_{51} \mathrm{H}_{62} \mathrm{Hg}_{0.5} \mathrm{~N}_{6} \mathrm{O}_{7.5} \mathrm{~S}_{3}$ \\
\hline Formula weight & 1075.54 \\
\hline Temperature/K & 296.06 \\
\hline Crystal system & monoclinic \\
\hline Space group & $\mathrm{C} 2 / \mathrm{c}$ \\
\hline $\mathrm{a} / \AA$ & $35.824(3)$ \\
\hline $\mathrm{b} / \AA$ & $12.9928(9)$ \\
\hline $\mathrm{c} / \AA$ & $23.3652(17)$ \\
\hline$\alpha /^{\circ}$ & 90 \\
\hline$\beta /{ }^{\circ}$ & $105.892(2)$ \\
\hline$\gamma /{ }^{\circ}$ & 90 \\
\hline Volume $/ \AA^{3}$ & $10459.8(13)$ \\
\hline $\mathrm{Z}$ & 8 \\
\hline$\rho_{\text {calc }} \mathrm{g} / \mathrm{cm}^{3}$ & 1.366 \\
\hline$\mu / \mathrm{mm}^{-1}$ & 1.658 \\
\hline $\mathrm{F}(000)$ & 4464.0 \\
\hline Crystal size $/ \mathrm{mm}^{3}$ & $0.122 \times 0.116 \times 0.075$ \\
\hline Radiation & $\operatorname{MoK} \alpha(\lambda=0.71076)$ \\
\hline $2 \Theta$ range for data collection $/{ }^{\circ}$ & 6.106 to 53.018 \\
\hline Index ranges & $-44 \leq \mathrm{h} \leq 44,-16 \leq \mathrm{k} \leq 16,-29 \leq 1 \leq 29$ \\
\hline Reflections collected & 68747 \\
\hline Independent reflections & $10793\left[\mathrm{R}_{\text {int }}=0.2651, \mathrm{R}_{\text {sigma }}=0.2443\right]$ \\
\hline Data/restraints/parameters & $10793 / 0 / 632$ \\
\hline Goodness-of-fit on $\mathrm{F}^{2}$ & 0.910 \\
\hline Final $\mathrm{R}$ indexes $[\mathrm{I}>=2 \sigma(\mathrm{I})]$ & $\mathrm{R}_{1}=0.0795, \mathrm{w} \mathrm{R}_{2}=0.1416$ \\
\hline Final $\mathrm{R}$ indexes [all data] & $\mathrm{R}_{1}=0.2226, \mathrm{wR}_{2}=0.1936$ \\
\hline Largest diff. peak/hole / e $\AA^{-3}$ & $0.72 /-0.76$ \\
\hline
\end{tabular}


Table 5.9. Bond Lengths for $\left[\mathrm{Hg}\left(\mathbf{L} \cdot \mathrm{H}_{2}\right)_{2}\left(\mathrm{H}_{2} \mathrm{O}\right)\right]$

\begin{tabular}{|c|c|c|c|c|c|}
\hline \multicolumn{2}{|c|}{\begin{tabular}{|l|l|} 
Atom Atom \\
\end{tabular}} & \multirow{2}{*}{$\frac{\text { Length/Å }}{2.037(6)}$} & \multicolumn{2}{|c|}{\begin{tabular}{|l|l|} 
Atom Atom \\
\end{tabular}} & \multirow{2}{*}{$\begin{array}{c}\text { Length } / \AA \AA \\
1.528(11)\end{array}$} \\
\hline $\mathrm{Hg} 1$ & $\mathrm{~N} 1^{1}$ & & C7 & C8 & \\
\hline Hg1 & N1 & $2.037(6)$ & C8 & C9 & $1.514(12)$ \\
\hline $\mathrm{Hg} 1$ & O10A & $2.66(4)$ & $\mathrm{C} 10$ & C11 & $1.536(13)$ \\
\hline S1 & O1 & $1.427(6)$ & C13 & C14 & $1.517(12)$ \\
\hline S1 & $\mathrm{O} 2$ & $1.425(6)$ & C16 & C17 & $1.350(11)$ \\
\hline S1 & N1 & $1.588(6)$ & C16 & C27 & $1.379(11)$ \\
\hline S1 & C16 & $1.798(9)$ & C17 & C18 & $1.393(12)$ \\
\hline S2 & $\mathrm{O} 3$ & $1.424(8)$ & C18 & C19 & $1.325(13)$ \\
\hline S2 & $\mathrm{O} 4$ & $1.430(8)$ & C19 & $\mathrm{C} 20$ & $1.441(13)$ \\
\hline S2 & N2 & $1.606(7)$ & C20 & $\mathrm{C} 21$ & $1.425(13)$ \\
\hline S2 & C28 & $1.750(9)$ & C20 & C27 & $1.434(12)$ \\
\hline S3 & $\mathrm{O} 5$ & $1.418(7)$ & C21 & $\mathrm{C} 22$ & $1.370(16)$ \\
\hline S3 & O6 & $1.430(7)$ & C22 & $\mathrm{C} 23$ & $1.393(18)$ \\
\hline S3 & N3 & $1.601(7)$ & $\mathrm{C} 23$ & $\mathrm{C} 24$ & $1.379(15)$ \\
\hline S3 & C40 & $1.762(10)$ & C24 & $\mathrm{C} 27$ & $1.431(13)$ \\
\hline N1 & $\mathrm{C} 1$ & $1.477(9)$ & C28 & C29 & $1.385(12)$ \\
\hline $\mathrm{N} 2$ & $\mathrm{C} 12$ & $1.456(10)$ & C28 & C37 & $1.421(12)$ \\
\hline N3 & C15 & $1.457(10)$ & C29 & C30 & $1.393(13)$ \\
\hline N4 & $\mathrm{C} 21$ & $1.409(14)$ & C30 & C31 & $1.342(13)$ \\
\hline N4 & $\mathrm{C} 25$ & $1.439(14)$ & C31 & C32 & $1.425(13)$ \\
\hline N4 & $\mathrm{C} 26$ & $1.449(14)$ & C32 & C33 & $1.448(13)$ \\
\hline N5 & C33 & $1.380(13)$ & C32 & C37 & $1.433(13)$ \\
\hline N5 & C38 & $1.465(15)$ & C33 & C34 & $1.368(14)$ \\
\hline N5 & C39 & $1.436(14)$ & C34 & C35 & $1.385(15)$ \\
\hline N6 & C49 & $1.426(12)$ & C35 & C36 & $1.347(14)$ \\
\hline N6 & C50 & $1.446(16)$ & C36 & C37 & $1.393(12)$ \\
\hline N6 & C51 & $1.468(15)$ & C40 & C41 & $1.365(13)$ \\
\hline C1 & $\mathrm{C} 2$ & $1.506(10)$ & C40 & C45 & $1.435(12)$ \\
\hline $\mathrm{C} 2$ & C3 & $1.400(11)$ & C41 & C42 & $1.432(17)$ \\
\hline $\mathrm{C} 2$ & C7 & $1.408(11)$ & C42 & C43 & $1.325(17)$ \\
\hline C3 & C4 & $1.399(10)$ & C43 & C44 & $1.401(14)$ \\
\hline C3 & $\mathrm{C} 10$ & $1.502(11)$ & C44 & C45 & $1.428(12)$ \\
\hline C4 & C5 & $1.394(10)$ & C44 & C49 & $1.439(14)$ \\
\hline C4 & C12 & $1.507(10)$ & C45 & C46 & $1.391(12)$ \\
\hline C5 & C6 & $1.412(10)$ & C46 & C47 & $1.357(12)$ \\
\hline C5 & C13 & $1.519(10)$ & C47 & C48 & $1.391(13)$ \\
\hline C6 & C7 & $1.390(10)$ & C48 & C49 & $1.339(13)$ \\
\hline C6 & C15 & $1.499(11)$ & $\mathrm{O} 10$ & O10A & $0.96(10)$ \\
\hline
\end{tabular}

${ }^{1} 1-\mathrm{X},+\mathrm{Y}, 1 / 2-\mathrm{Z}$ 
Table 5.10. Bond Angles for $\left[\mathrm{Hg}\left(\mathbf{L} \cdot \mathrm{H}_{2}\right)_{2}\left(\mathrm{H}_{2} \mathrm{O}\right)\right]$

\begin{tabular}{|c|c|c|c|c|c|c|c|}
\hline \multicolumn{3}{|c|}{ Atom Atom Atom } & \multirow{2}{*}{$\begin{array}{c}\text { Angle }^{\circ} \\
174.1 \text { (4) }\end{array}$} & \multicolumn{3}{|c|}{ Atom Atom Atom } & \multirow{2}{*}{$\begin{array}{l}\text { Angle }^{\circ} \\
113.7(7)\end{array}$} \\
\hline $\mathrm{N} 1^{1}$ & $\mathrm{Hg} 1$ & N1 & & C14 & $\mathrm{C} 13$ & $\mathrm{C} 5$ & \\
\hline N1 & $\mathrm{Hg} 1$ & O10A & $89.8(9)$ & N3 & $\mathrm{C} 15$ & C6 & $108.9(7)$ \\
\hline $\mathrm{N} 1^{1}$ & $\mathrm{Hg} 1$ & O10A & $95.7(9)$ & $\mathrm{C} 17$ & $\mathrm{C} 16$ & S1 & $115.6(7)$ \\
\hline O1 & $\mathrm{S} 1$ & N1 & $112.6(4)$ & $\mathrm{C} 17$ & $\mathrm{C} 16$ & $\mathrm{C} 27$ & $121.4(9)$ \\
\hline O1 & S1 & C16 & $104.2(4)$ & $\mathrm{C} 27$ & $\mathrm{C} 16$ & $\mathrm{~S} 1$ & $122.5(8)$ \\
\hline $\mathrm{O} 2$ & S1 & $\mathrm{O} 1$ & $116.1(4)$ & C16 & $\mathrm{C} 17$ & $\mathrm{C} 18$ & $120.9(9)$ \\
\hline $\mathrm{O} 2$ & S1 & N1 & $107.1(4)$ & C19 & $\mathrm{C} 18$ & $\mathrm{C} 17$ & $120.8(10)$ \\
\hline $\mathrm{O} 2$ & S1 & $\mathrm{C} 16$ & $112.7(4)$ & $\mathrm{C} 18$ & C19 & $\mathrm{C} 20$ & $120.3(9)$ \\
\hline N1 & $\mathrm{S} 1$ & $\mathrm{C} 16$ & $103.5(4)$ & $\mathrm{C} 21$ & $\mathrm{C} 20$ & $\mathrm{C} 19$ & $119.7(10)$ \\
\hline $\mathrm{O} 3$ & S2 & $\mathrm{O} 4$ & $119.2(6)$ & $\mathrm{C} 21$ & $\mathrm{C} 20$ & $\mathrm{C} 27$ & $122.3(10)$ \\
\hline $\mathrm{O} 3$ & S2 & $\mathrm{N} 2$ & $109.5(5)$ & $\mathrm{C} 27$ & $\mathrm{C} 20$ & C19 & $117.8(8)$ \\
\hline O3 & S2 & $\mathrm{C} 28$ & $106.4(5)$ & $\mathrm{N} 4$ & $\mathrm{C} 21$ & $\mathrm{C} 20$ & $119.7(12)$ \\
\hline $\mathrm{O} 4$ & S2 & $\mathrm{N} 2$ & $105.3(5)$ & $\mathrm{C} 22$ & $\mathrm{C} 21$ & $\mathrm{~N} 4$ & $123.6(12)$ \\
\hline $\mathrm{O} 4$ & S2 & $\mathrm{C} 28$ & $108.6(5)$ & $\mathrm{C} 22$ & $\mathrm{C} 21$ & $\mathrm{C} 20$ & $116.7(12)$ \\
\hline $\mathrm{N} 2$ & S2 & $\mathrm{C} 28$ & $107.3(4)$ & $\mathrm{C} 21$ & $\mathrm{C} 22$ & $\mathrm{C} 23$ & $122.5(12)$ \\
\hline O5 & S3 & O6 & $119.8(5)$ & $\mathrm{C} 24$ & $\mathrm{C} 23$ & $\mathrm{C} 22$ & $122.1(13)$ \\
\hline O5 & S3 & N3 & $107.0(4)$ & $\mathrm{C} 23$ & $\mathrm{C} 24$ & $\mathrm{C} 27$ & $118.7(12)$ \\
\hline O5 & S3 & $\mathrm{C} 40$ & $109.9(4)$ & C16 & $\mathrm{C} 27$ & $\mathrm{C} 20$ & $118.4(9)$ \\
\hline O6 & S3 & N3 & $106.9(4)$ & C16 & $\mathrm{C} 27$ & $\mathrm{C} 24$ & $124.0(10)$ \\
\hline O6 & S3 & $\mathrm{C} 40$ & $105.7(5)$ & $\mathrm{C} 24$ & $\mathrm{C} 27$ & $\mathrm{C} 20$ & $117.7(9)$ \\
\hline N3 & S3 & $\mathrm{C} 40$ & $106.8(4)$ & $\mathrm{C} 29$ & $\mathrm{C} 28$ & $\mathrm{~S} 2$ & $116.7(8)$ \\
\hline S1 & N1 & $\mathrm{Hg} 1$ & $119.8(4)$ & $\mathrm{C} 29$ & $\mathrm{C} 28$ & C37 & $120.2(9)$ \\
\hline C1 & N1 & $\mathrm{Hg} 1$ & $119.3(5)$ & C37 & $\mathrm{C} 28$ & S2 & $123.0(7)$ \\
\hline C1 & N1 & S1 & $116.1(5)$ & $\mathrm{C} 28$ & $\mathrm{C} 29$ & $\mathrm{C} 30$ & $121.3(10)$ \\
\hline C12 & $\mathrm{N} 2$ & $\mathrm{~S} 2$ & $122.8(6)$ & C31 & C30 & $\mathrm{C} 29$ & $119.7(10)$ \\
\hline C15 & N3 & S3 & $121.9(6)$ & C30 & C31 & C32 & $122.3(10)$ \\
\hline C21 & $\mathrm{N} 4$ & $\mathrm{C} 25$ & $116.0(10)$ & C31 & C32 & C33 & $121.6(10)$ \\
\hline C21 & N4 & $\mathrm{C} 26$ & $115.9(11)$ & $\mathrm{C} 31$ & C32 & C37 & $118.4(9)$ \\
\hline C25 & N4 & $\mathrm{C} 26$ & $112.1(9)$ & C 37 & $\mathrm{C} 32$ & $\mathrm{C} 33$ & $120.1(10)$ \\
\hline C33 & N5 & C38 & $113.9(10)$ & N5 & C33 & C32 & $116.9(11)$ \\
\hline C33 & N5 & C39 & $114.7(11)$ & $\mathrm{C} 34$ & $\mathrm{C} 33$ & N5 & $126.5(11)$ \\
\hline C39 & N5 & C38 & $111.8(10)$ & C34 & C33 & C32 & $116.5(10)$ \\
\hline C49 & N6 & C50 & $113.9(10)$ & C33 & C34 & C35 & $122.3(11)$ \\
\hline C49 & N6 & $\mathrm{C} 51$ & $114.7(11)$ & C36 & C35 & C34 & $121.9(11)$ \\
\hline C50 & N6 & $\mathrm{C} 51$ & $112.5(12)$ & $\mathrm{C} 35$ & C36 & C37 & $120.2(11)$ \\
\hline N1 & $\mathrm{C} 1$ & $\mathrm{C} 2$ & $109.6(6)$ & $\mathrm{C} 28$ & C37 & C32 & $118.0(9)$ \\
\hline C3 & $\mathrm{C} 2$ & $\mathrm{C} 1$ & $118.4(7)$ & C36 & C37 & $\mathrm{C} 28$ & $123.2(10)$ \\
\hline C3 & $\mathrm{C} 2$ & C7 & $120.5(7)$ & $\mathrm{C} 36$ & C37 & $\mathrm{C} 32$ & $118.7(10)$ \\
\hline
\end{tabular}




\begin{tabular}{|c|c|c|c|c|c|c|c|}
\hline $\mathrm{C7}$ & $\mathrm{C} 2$ & $\mathrm{C} 1$ & $121.0(8)$ & $\mathrm{C} 41$ & $\mathrm{C} 40$ & S3 & $117.3(8)$ \\
\hline $\mathrm{C} 2$ & $\mathrm{C} 3$ & $\mathrm{C} 10$ & $119.5(7)$ & $\mathrm{C} 41$ & $\mathrm{C} 40$ & $\mathrm{C} 45$ & $120.6(10)$ \\
\hline C4 & $\mathrm{C} 3$ & $\mathrm{C} 2$ & $119.1(8)$ & $\mathrm{C} 45$ & $\mathrm{C} 40$ & S3 & $122.1(7)$ \\
\hline $\mathrm{C} 4$ & C3 & $\mathrm{C} 10$ & $121.4(8)$ & $\mathrm{C} 40$ & $\mathrm{C} 41$ & $\mathrm{C} 42$ & $119.6(11)$ \\
\hline C3 & $\mathrm{C} 4$ & $\mathrm{C} 12$ & $119.3(7)$ & $\mathrm{C} 43$ & $\mathrm{C} 42$ & C41 & $119.9(11)$ \\
\hline C5 & $\mathrm{C} 4$ & C3 & $120.8(7)$ & $\mathrm{C} 42$ & $\mathrm{C} 43$ & $\mathrm{C} 44$ & $123.2(12)$ \\
\hline C5 & $\mathrm{C} 4$ & $\mathrm{C} 12$ & $119.7(7)$ & $\mathrm{C} 43$ & $\mathrm{C} 44$ & $\mathrm{C} 45$ & $118.0(11)$ \\
\hline C4 & C5 & C6 & $119.8(7)$ & $\mathrm{C} 43$ & $\mathrm{C} 44$ & C49 & $122.8(11)$ \\
\hline C4 & C5 & C13 & $120.8(7)$ & $\mathrm{C} 45$ & $\mathrm{C} 44$ & C49 & $118.9(9)$ \\
\hline C6 & $\mathrm{C} 5$ & C13 & $119.4(7)$ & $\mathrm{C} 44$ & $\mathrm{C} 45$ & $\mathrm{C} 40$ & $118.1(9)$ \\
\hline $\mathrm{C} 5$ & C6 & $\mathrm{C} 15$ & $120.3(7)$ & $\mathrm{C} 46$ & $\mathrm{C} 45$ & $\mathrm{C} 40$ & $123.5(9)$ \\
\hline C7 & C6 & $\mathrm{C} 5$ & $119.8(7)$ & $\mathrm{C} 46$ & $\mathrm{C} 45$ & $\mathrm{C} 44$ & $118.4(9)$ \\
\hline C7 & C6 & $\mathrm{C} 15$ & $119.8(8)$ & $\mathrm{C} 47$ & $\mathrm{C} 46$ & $\mathrm{C} 45$ & $120.4(8)$ \\
\hline $\mathrm{C} 2$ & $\mathrm{C} 7$ & $\mathrm{C} 8$ & $120.5(7)$ & $\mathrm{C} 46$ & $\mathrm{C} 47$ & $\mathrm{C} 48$ & $121.8(9)$ \\
\hline C6 & $\mathrm{C} 7$ & $\mathrm{C} 2$ & $119.9(8)$ & C49 & $\mathrm{C} 48$ & $\mathrm{C} 47$ & $120.6(10)$ \\
\hline C6 & C7 & $\mathrm{C} 8$ & $119.6(8)$ & N6 & $\mathrm{C} 49$ & $\mathrm{C} 44$ & $116.7(11)$ \\
\hline C9 & $\mathrm{C} 8$ & $\mathrm{C} 7$ & $113.5(7)$ & $\mathrm{C} 48$ & $\mathrm{C} 49$ & N6 & $123.6(11)$ \\
\hline C3 & $\mathrm{C} 10$ & $\mathrm{C} 11$ & $113.0(8)$ & $\mathrm{C} 48$ & C49 & $\mathrm{C} 44$ & $119.7(9)$ \\
\hline $\mathrm{N} 2$ & $\mathrm{C} 12$ & $\mathrm{C} 4$ & $108.5(7)$ & $\mathrm{O} 10$ & $\mathrm{O} 10 \mathrm{~A}$ & $\mathrm{Hg} 1$ & $85(4)$ \\
\hline
\end{tabular}

\subsection{References}

(1) Renzoni, A.; Zino, F.; Franchi, E. Mercury Levels along the Food Chain and Risk for Exposed Populations. Environ. Res. 1998, 77, 68-72.

(2) Harris, H. H.; Pickering, I. J.; George, G. N. The Chemical Form of Mercury in Fish. Science, 2003, 301, 1203 LP-1203.

(3) Tchounwou, P. B.; Yedjou, C. G.; Patlolla, A. K.; Sutton, D. J. Heavy Metals Toxicity and the Environment. EXS 2012, 101, 133-164.

(4) Akagi, H.; Grandjean, P.; Takizawa, Y.; Weihe, P. Methylmercury Dose Estimation from Umbilical Cord Concentrations in Patients with Minamata Disease. Environ. Res. 1998, 77, 98-103.

(5) Cavalleri, A.; Gobba, F. Reversible Color Vision Loss in Occupational Exposure to Metallic Mercury. Environ. Res. 1998, 77, 173-177.

(6) Grandjean, P.; Weihe, P.; White, R. F.; Debes, F. Cognitive Performance of Children Prenatally Exposed to "Safe" Levels of Methylmercury. Environ. Res. 1998, 77, $165-172$.

(7) Henriksson, J.; Tjälve, H. Uptake of Inorganic Mercury in the Olfactory Bulbs via Olfactory Pathways in Rats. Environ. Res. 1998, 77, 130-140. 
(8) Mahaffey, K. R.; Mergler, D. Blood Levels of Total and Organic Mercury in Residents of the Upper St. Lawrence River Basin, Québec: Association with Age, Gender, and Fish Consumption. Environ. Res. 1998, 77, 104-114.

(9) Shenker, B. J.; Guo, T. L.; Shapiro, I. M. Low-Level Methylmercury Exposure Causes Human T-Cells to Undergo Apoptosis: Evidence of Mitochondrial Dysfunction. Environ. Res. 1998, 77, 149-159.

(10) Zhou, Y.; Ma, Z. Colorimetric Detection of Hg (II) by Au Nanoparticles Formed by $\mathrm{H}_{2} \mathrm{O}_{2}$ Reduction of $\mathrm{HAuCl}_{4}$ Using Au Nanoclusters as the Catalyst. Sensors Actuators B Chem. 2017, 241, 1063-1068.

(11) Tan, L.; Zhang, Y.; Qiang, H.; Li, Y.; Sun, J.; Hu, L.; Chen, Z. A Sensitive Hg(II) Colorimetric Sensor Based on Synergistic Catalytic Effect of Gold Nanoparticles and Hg. Sensors Actuators B Chem. 2016, 229, 686-691.

(12) Zhao, Y.; Gui, L.; Chen, Z. Colorimetric Detection of Hg (II) Based on TargetMediated Growth of Gold Nanoparticles. Sensors Actuators B Chem. 2017, 241, 262-267.

(13) Tian, K.; Siegel, G.; Tiwari, A. A Simple and Selective Colorimetric Mercury (II) Sensing System Based on Chitosan Stabilized Gold Nanoparticles and 2,6Pyridinedicarboxylic Acid. Mater. Sci. Eng. C 2017, 71, 195-199.

(14) Che, Y.; Wu, D.; Deng, C.; Liu, L.; Jia, D. 5-Bromoindole-3-Carboxaldehyde Ethylthiosemicarbazone for $\mathrm{Hg}(\mathrm{II})$ Sensing and Removal. Chem. Phys. Lett. 2016, 644, 171-175.

(15) Angupillai, S.; Hwang, J.-Y.; Lee, J.-Y.; Rao, B. A.; Son, Y.-A. Efficient Rhodamine-Thiosemicarbazide-Based Colorimetric/fluorescent "Turn-On" Chemodosimeters for the Detection of $\mathrm{Hg}$ (II) in Aqueous Samples. Sensors Actuators B Chem. 2015, 214, 101-110.

(16) Song, K.; Mo, J.; Lu, C. Hg(II) Sensing Platforms with Improved Photostability: The Combination of Rhodamine Derived Chemosensors and up-Conversion Nanocrystals. Spectrochim. Acta Part A Mol. Biomol. Spectrosc. 2017, 179, 125131.

(17) Wan, D.; Li, Y.; Zhu, P. A Series of Emission "turn-On" Probes Derived from Rhodamine for $\mathrm{Hg}$ (II) Recognition and Sensing: Synthesis, Characterization and Performance. Sensors Actuators B Chem. 2015, 221, 1271-1278.

(18) Nutiu, R.; Li, Y. Structure-Switching Signaling Aptamers. J. Am. Chem. Soc. 2003, $125,4771$.

(19) Jun, W.; Kai, R.; Beijing, H. Synthesis and Sensing Behavior of Fluorescence "turnOn" Chemosensors Based on Rhodamine for $\mathrm{Hg}(\mathrm{II})$ Detection. Sensors Actuators B Chem. 2016, 224, 465-477. 
(20) Ramette, R. W.; Sandell, E. B. Rhodamine B Equilibria. J. Am. Chem. Soc. 1956, $78,4872-4878$.

(21) Zhou, S.; Zhou, Z.-Q.; Zhao, X.-X.; Xiao, Y.-H.; Xi, G.; Liu, J.-T.; Zhao, B.-X. A Dansyl Based Fluorescence Chemosensor for $\mathrm{Hg}(\mathrm{II})$ and Its Application in the Complicated Environment Samples. Spectrochim. Acta Part A Mol. Biomol. Spectrosc. 2015, 148, 348-354.

(22) Srivastava, P.; Ali, R.; Razi, S. S.; Shahid, M.; Patnaik, S.; Misra, A. A Simple Blue Fluorescent Probe to Detect $\mathrm{Hg}$ (II) in Semiaqueous Environment by Intramolecular Charge Transfer Mechanism. Tetrahedron Lett. 2013, 54, 3688-3693.

(23) Wanichacheva, N.; Kumsorn, P.; Sangsuwan, R.; Kamkaew, A.; Lee, V. S.; Grudpan, K. A New Fluorescent Sensor Bearing Three Dansyl Fluorophores for Highly Sensitive and Selective Detection of $\mathrm{Hg}(\mathrm{II})$ Ions. Tetrahedron Lett. 2011, 52, 6133-6136.

(24) Li, H.-W.; Wang, B.; Dang, Y.-Q.; Li, L.; Wu, Y. A Highly Selective Fluorescent Sensor for Mercury Ions in Aqueous Solution: Detection Based on Target-Induced Aggregation. Sensors Actuators B Chem. 2010, 148, 49-53.

(25) Métivier, R.; Leray, I.; Valeur, B. Lead and Mercury Sensing by Calixarene-Based Fluoroionophores Bearing Two or Four Dansyl Fluorophores. Chem.- A Eur. J. 2004, 10, 4480-4490.

(26) Kilway, K. V; Siegel, J. S. Control of Functional Group Proximity and Direction by Conformational Networks: Synthesis and Stereodynamics of Persubstituted Arenes. Tetrahedron 2001, 57, 3615-3627.

(27) Software for the Integration of CCD Detector System Bruker Analytical X-ray Systems, Bruker axs, Madison, WI , 2013

(28) Sheldrick, G.M., Crystal structure refinement with ShelXL, Acta Cryst., 2015, C27, 3-8.

(29) Sheldrick, G.M., ShelXT-Integrated space-group and crystal-structure determination, Acta Cryst., 2015, A71, 3-8.

(30) O. V. Dolomanov and L. J. Bourhis and R. J. Gildea and J. A. K. Howard and H. Puschmann, Olex 2: A complete structure solution, refinement and analysis program, J. Appl. Cryst., 2009, 42, 339-341. 


\section{CHAPTER VI}

General Conclusions

In this work we have showed the role of ion pairing on the binding and sensing selectivity for different species by tris-pyrazole and tris-dansyl ion receptors, derived from 1,3,5-triethylbenzene. In Chapter II, we reported two tris-pyrazole fluorescent sensors for $\mathrm{NH}_{4}{ }^{+}$based on 1,3,5-triethylbenzene that show binding and sensing selectivity for $\mathrm{NH}_{4}^{+}$vs. $\mathrm{K}^{+}$. Non-linear regression analysis of the binding isotherms obtained gave a 1:1 association constant $\mathrm{K}_{\mathrm{a}}$ of $74000( \pm 900) \mathrm{M}^{-1}$ for the formation of $\mathbf{1} \cdot \mathrm{NH}_{4}{ }^{+}$and a $\mathrm{K}_{\mathrm{a}}$ of $15 \mathrm{M}^{-1}$ for the formation of $\mathbf{2} \mathrm{NH}_{4}{ }^{+}$which is almost four orders of magnitude lower than those of the dimethyl analog $\mathbf{1}$. This difference in binding cannot be simply explained by electronic and steric effects, as the cavity of the tris(diphenyl)pyrazole can comfortably accommodate the $\mathrm{NH}_{4}{ }^{+}$(unlike for $\mathbf{1}$ ) The role of ion pairing and solvation was revealed by X-ray and theoretical DFT studies. The X-ray structure of $\mathbf{2} \mathrm{NH}_{4}{ }^{+}$and DFT calculations for $\mathbf{1}, \mathbf{2}$ and their corresponding $\mathrm{NH}_{4}{ }^{+}$complexes provide consistent information related to the lack of ion pairing of $\mathrm{NH}_{4}{ }^{+}$with the $\mathrm{PF}_{6}^{-}$counteranion for 2 .

In Chapter III, we demonstrated a unique dual-host extraction-based ion-pair sensing paradigm using Förster Resonance Energy Transfer (FRET), showing selectivity for $\mathrm{NH}_{4} \mathrm{NO}_{3}$. The fluorescence emission of the $\mathrm{NH}_{4}{ }^{+}$sensor tris- $(3,5-$ dimethyl)pyrazole $(305-340 \mathrm{~nm})$, is compatible with the excitation wavelength of the dansyl fluorophore of the nitrate sensor 1,3,5-tris-(5-dimethylamino-1naphthalenesulfonamido)methyl]-2,4,6-triethylbenzene, thus resulting in FRET emission upon combined use of these two sensors for the $\mathrm{NH}_{4} \mathrm{NO}_{3}$ ion pair. Contact 
of dichloromethane solutions containing the two hosts with aqueous solutions of $\mathrm{NH}_{4} \mathrm{NO}_{3}\left(1.0 \times 10^{-5} \mathrm{M}\right.$ to $\left.1.0 \times 10^{-4} \mathrm{M}\right)$, resulted in FRET fluorescence enhancements at $510 \mathrm{~nm}$, with increasing concentrations of $\mathrm{NH}_{4} \mathrm{NO}_{3}$, while $\mathrm{NaNO}_{3}$, $\mathrm{KNO}_{3}, \mathrm{NaCl}$ and $\mathrm{KCl}$ showed only minimal fluorescence responses, under identical conditions. In Chapter IV, we exploited the ability of the tris-pyrazole to bind $\operatorname{Ln}(\mathrm{III})$ ions. Investigations of binding and sensing of different $\operatorname{Ln}(\mathrm{III})$ via fluorescence and ${ }^{1} \mathrm{H}-\mathrm{NMR}$ showed the same dependence of fluorescence responses on pyrazole substitution patterns that had been observed for $\mathrm{NH}_{4}{ }^{+}$, indicating the significant role of ion pairing for $\mathrm{Ln}(\mathrm{III})$ binding and fluorescence sensing. In Chapter V, the trisdansyl nitrate receptor $\mathrm{LH}_{3}$, was found to be an efficient $\mathrm{Hg}$ (II) fluorescent sensor. An X-ray crystal structure showed the ability of the trianionic version of this receptor to bind three $\mathrm{Hg}(\mathrm{II})$ atoms, also containing three $\mathrm{CH}_{3} \mathrm{COO}^{-}$counteranions. The X-ray crystal structure of the same receptor with $\mathrm{HgCl}_{2}$ showed a 2:1 complexation pattern, with one $\mathrm{Hg}$ atom complexed by two bis-deprotonated receptor molecules. 


\section{APPENDIX A}

\section{Ammonium Fluorescence Sensing by 1,3,5-Tris(4-methyl-2-oxazolinylmethyl)-2,4,6- triethylbenzene (1)}

Tosin M. Jonah and Konstantinos Kavallieratos

Department of Chemistry and Biochemistry and the Biomolecular Sciences Institute, Florida International University,11200 SW $8^{\text {th }}$ St, Miami, FL 33199, USA.

\section{A.1. Introduction}

The design and synthesis of selective ammonium receptors and sensors is of biological and environmental importance. Synthetic receptors for $\mathrm{NH}_{4}{ }^{+}$have found uses in measuring the urea and creatine levels and in environmental applications. ${ }^{1-3} \mathrm{NH}_{4}{ }^{+}$over $\mathrm{K}^{+}$selectivity is always a challenge due to the similarity in ionic radii between these ions (286 vs. 266 pm for $\mathrm{NH}_{4}{ }^{+}$vs $\mathrm{K}^{+}$, respectively). Several ammonium receptors have been reported ${ }^{4-7}$ that bind to ammonium via hydrogen bonding, including derivatives of crown ethers and nonactin. ${ }^{8}$ A highly sensitive and selective cage-type $\mathrm{NH}_{4}{ }^{+}$receptor based on cation- $\pi$ interaction and hydrogen bonding. ${ }^{9,14}$ This receptor is comparable to nonactin in terms of selectivity and sensitivity.Tripodal oxazolines have been shown to bind ammonium through hydrogen bonding and cation- $\pi$ interactions. ${ }^{9,10}$ These include a trimethyl oxazoline analog derived from 1,3,5-trimethylbenzene ${ }^{8,12,13}$ that showed selective fluorescence response at the $305-340 \mathrm{~nm}$ range $\left(\lambda_{\mathrm{exc}}=272 \mathrm{~nm}\right)$, for ammonium over $\mathrm{K}^{+}$, $\mathrm{Na}^{+}$, and $\mathrm{Mg}^{2+}$. 
Herein, we report a new oxazoline (1) receptor, based on the 1,3,5-triethylbenzene framework. The tris-oxazoline 1 , is selective for $\mathrm{NH}_{4}{ }^{+}$over $\mathrm{K}^{+}$. The binding constants by NMR titrations reveal remarkable binding strength and selectivity for $\mathrm{NH}_{4}{ }^{+}$over $\mathrm{K}^{+}$for $\mathbf{1}$.

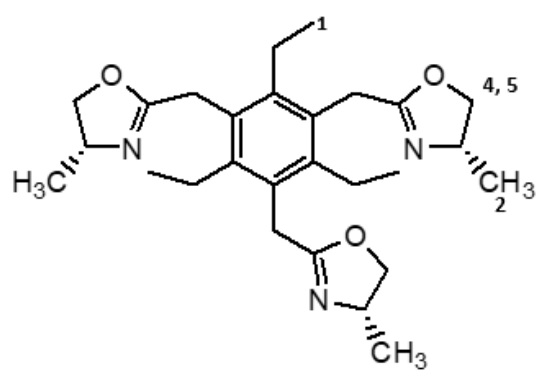

Figure A.1. Chemical structure of receptor 1

\section{A.2 Results and Discussion}

Compound 1 was prepared by modifications of previously reported methods. ${ }^{11,15}$ Fluorescence titrations of receptors with $\mathrm{NH}_{4} \mathrm{PF}_{6}$ at constant receptor concentration (1.0 x $\left.10^{-4} \mathrm{M}\right)$ were carried out in $\mathrm{CH}_{3} \mathrm{OH}$ for $\mathbf{1}(1: 1)$ for $\mathbf{2}$ and $\mathbf{3}\left(\lambda_{\mathrm{exc}}=272 \mathrm{~nm}\right)$. The results for tris-oxazoline 1 were comparable to the trimethyl analog reported in the literature with increase in fluorescence higher for $\mathrm{NH}_{4}{ }^{+} v s . \mathrm{K}^{+}$and $\mathrm{Na}^{+} .{ }^{13}$ The tris-(oxazoline) ammonium sensor 1 was prepared in good yields using modified versions of reported ${ }^{8}$ procedures for the trimethylbenzene analog (Scheme 1). 


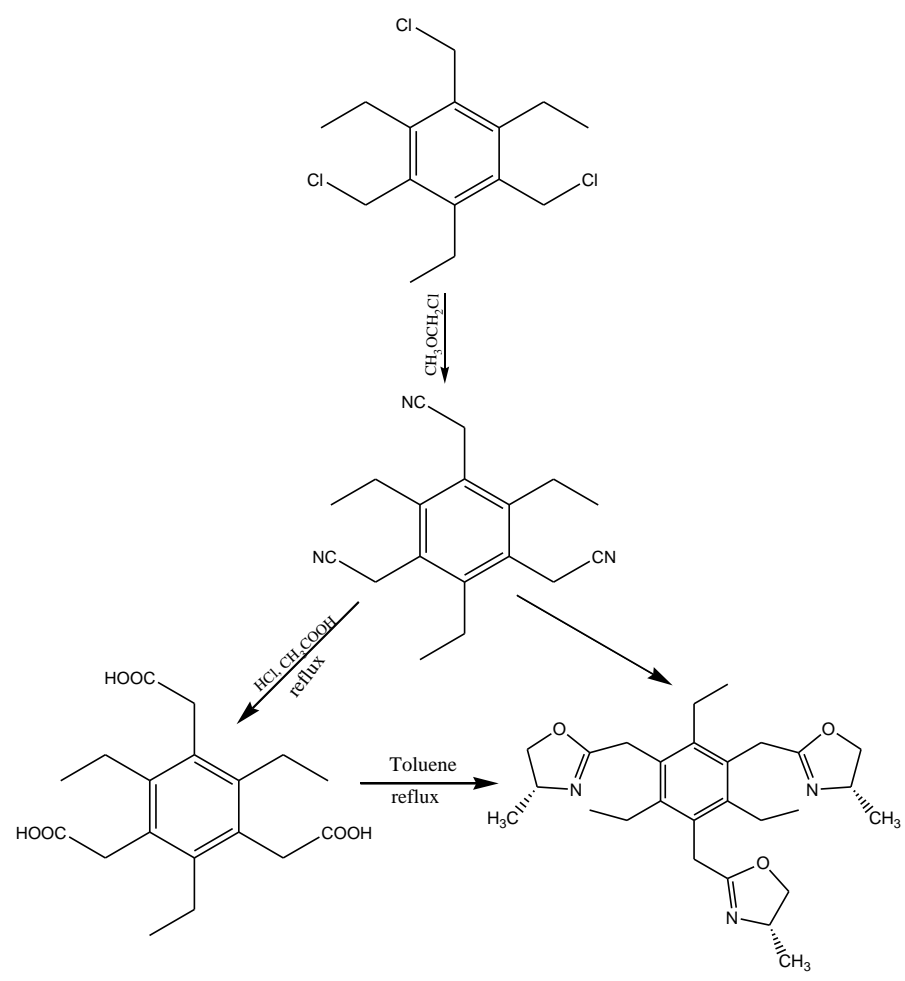

Scheme A. 1: Synthetic scheme for preparation of tris-(oxazoline) ammonium sensor 1.

Fluorescence titrations of 1 with $\mathrm{NH}_{4}{ }^{+} \mathrm{PF}_{6}{ }^{-}$and $\mathrm{K}^{+} \mathrm{PF}_{6}{ }^{-}$were carried out. Emission was measured using an excitation wavelength of $272 \mathrm{~nm}$. The fluorescence intensity increased gradually with increase in the amount of $\mathrm{NH}_{4}{ }^{+}$added (Figure A.2 and A.3) while a decrease in fluorescence intensity (quenching) was observed when $\mathbf{1}$ was titrated with $\mathrm{K}^{+} \mathrm{PF}_{6}^{-}$(figure A.4). 


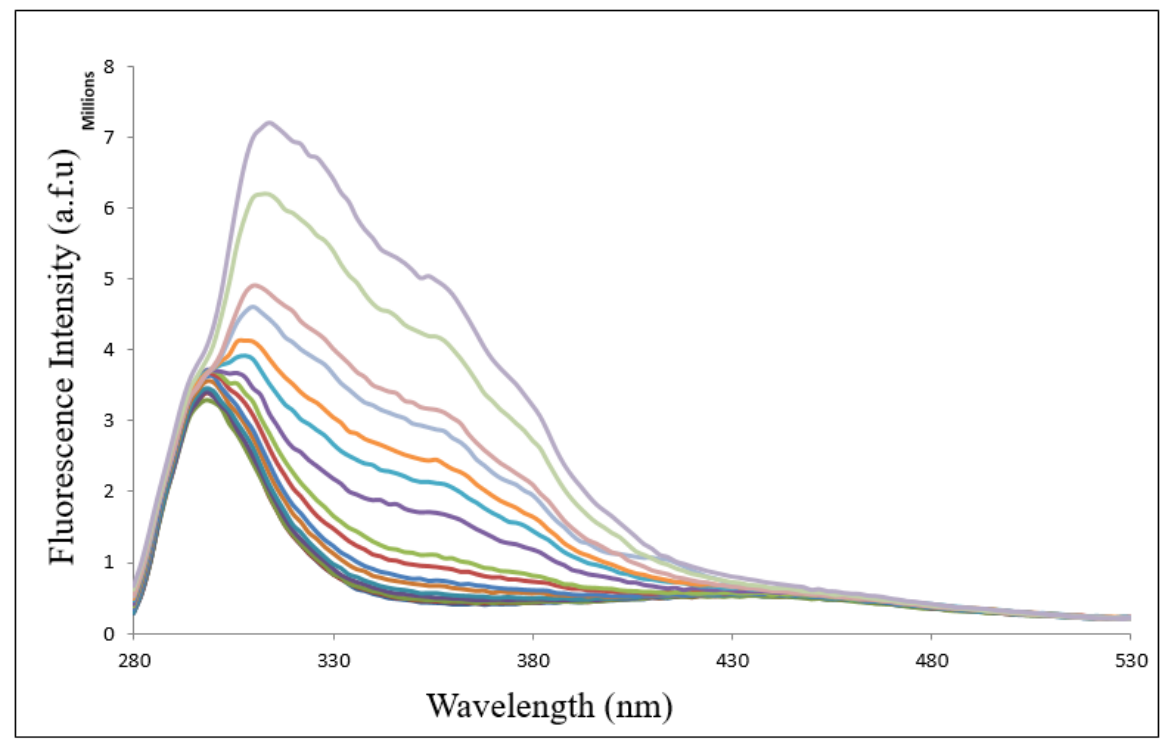

Figure A.2: Fluorescence Titration of 1 with $\mathrm{NH}_{4}{ }^{+} \mathrm{PF}_{6}{ }^{-}$in $\mathrm{CD}_{3} \mathrm{OD}\left(\lambda_{\text {exc }}=272 \mathrm{~nm}\right)$.

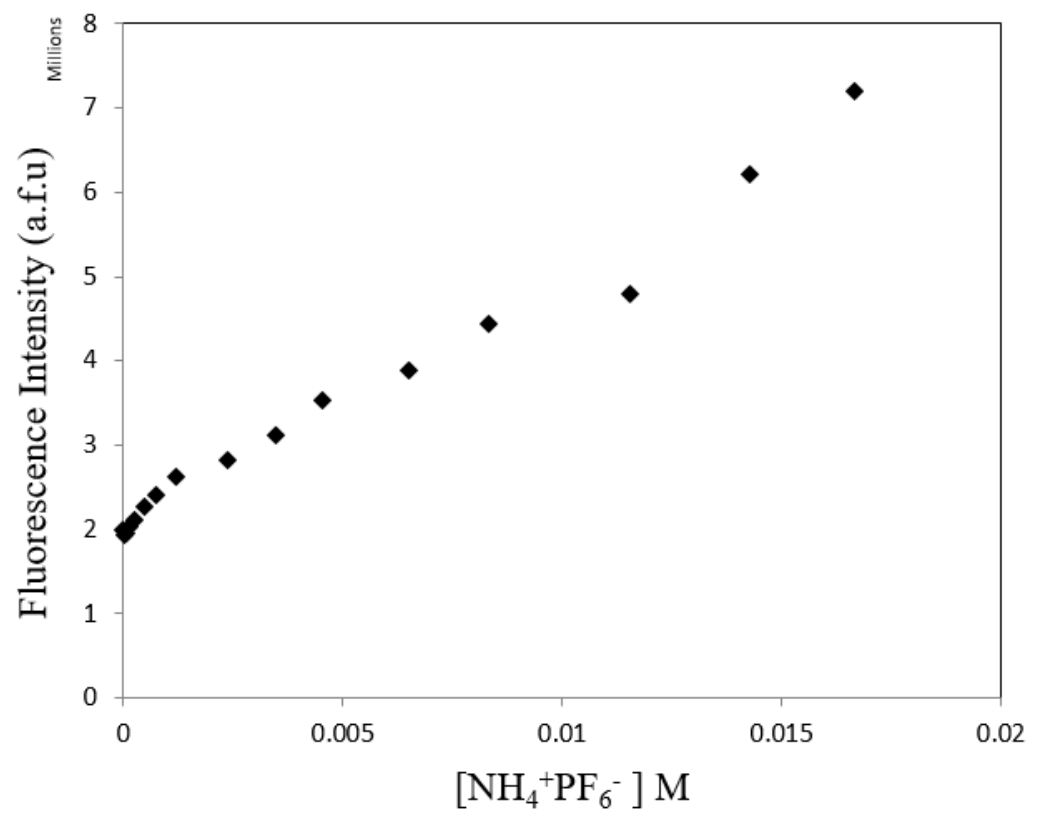

Figure A.3: Fluorescence Titration curve of 1 with $\mathrm{NH}_{4}{ }^{+} \mathrm{PF}_{6}{ }^{-}\left(\lambda_{\text {exc }}=272 \mathrm{~nm}\right)$ 


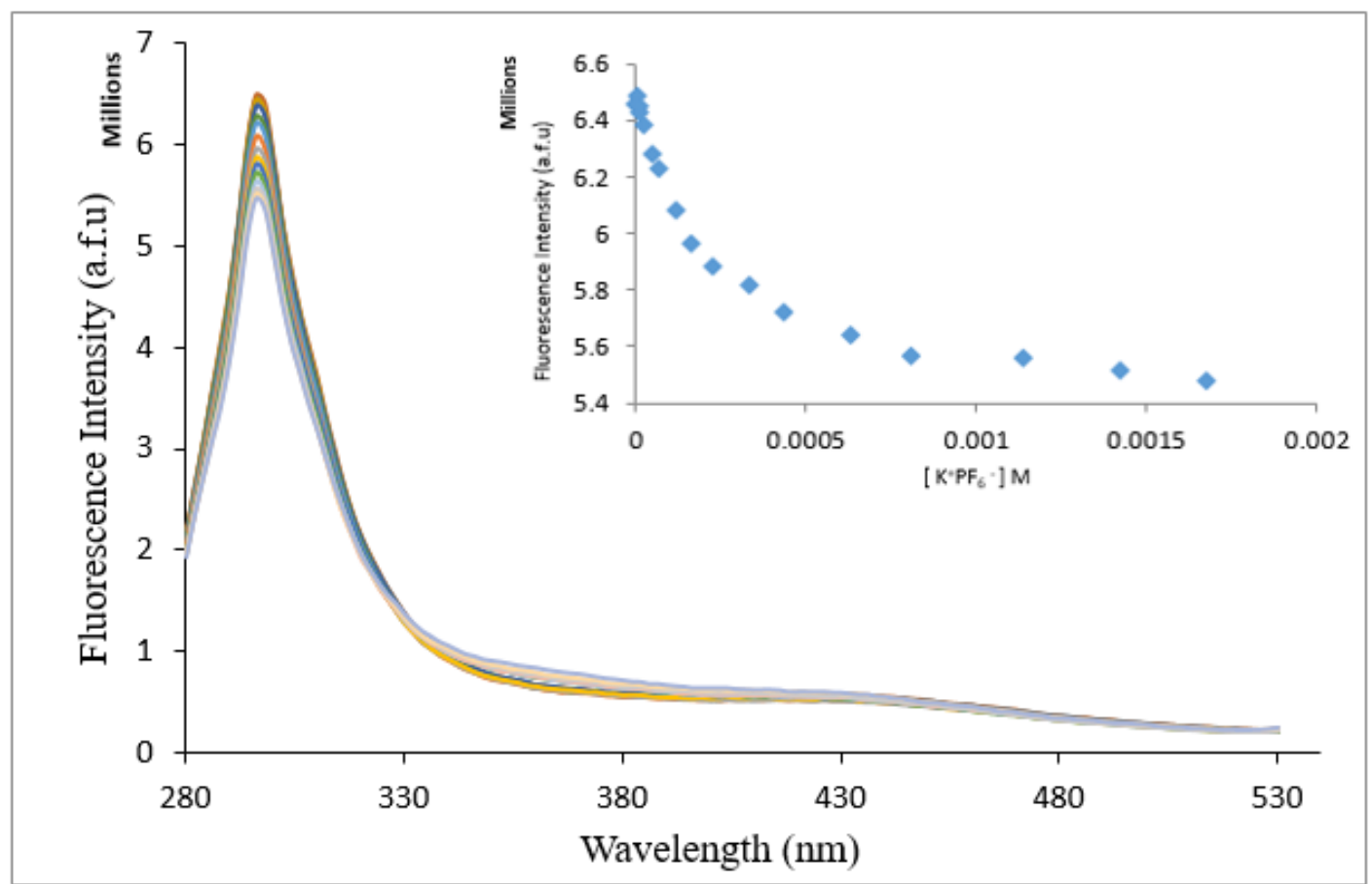

Figure A.4: Fluorescence titration curve of 1 with $\mathrm{K}^{+} \mathrm{PF}_{6}^{-}\left(\lambda_{\text {exc }}=272 \mathrm{~nm}\right)$.

The $\mathrm{NH}_{4}{ }^{+}$binding properties of receptor 1 were investigated by ${ }^{1} \mathrm{H}-\mathrm{NMR}$ titrations in $\mathrm{CD}_{3} \mathrm{OD}$ by with $\mathrm{NH}_{4}{ }^{+} \mathrm{PF}_{6}$. Downfield shifts of the oxazolinyl proton resonance were observed, indicating cation binding via hydrogen bonding (Figure A.5). The electron cloud above and below the plane of the ring circulates in reaction to the external field so as to generate an opposing field at the center of the ring and a supporting field at the edge of the ring. Regions in which the induced field supports or adds to the external field are said to be deshielded, because a slightly weaker external field will bring about resonance for nuclei in such areas. While regions in which the induced field opposes the external field are termed shielded because an increase in the applied field is needed for resonance. 
The benzylic $\mathrm{CH}_{3}$ and $\mathrm{CH}_{2}$ also showed some slight observable upfield shifts. This upfield shield seen in the benzylic $\mathrm{CH}_{3}$ and $\mathrm{CH}_{2}$ may be because the cation- $\pi$ interactions disturb the delocalization of the benzene $\pi$ electrons which subsequently results to a decrease in their deshielding effects. Association constants for the formation of 1:1 complexes, $\mathrm{K}_{\mathrm{a}}$, were determined by non-linear regression analysis using the 1:1 binding isotherm (Eq. 1), to be $737 \mathrm{M}^{-1}$ for $1 . \mathrm{NH}_{4}{ }^{+}$while a $\mathrm{K}_{\mathrm{a}}$ of $72 \mathrm{M}^{-1}$ was obtained for $1 . \mathrm{K}^{+}$. The continuous variation method (Job Plot) by ${ }^{1} \mathrm{H}-\mathrm{NMR}$ gave a 1:1 binding stoichiometry for 1. $\mathrm{NH}_{4}{ }^{+}$(Figure A.7).

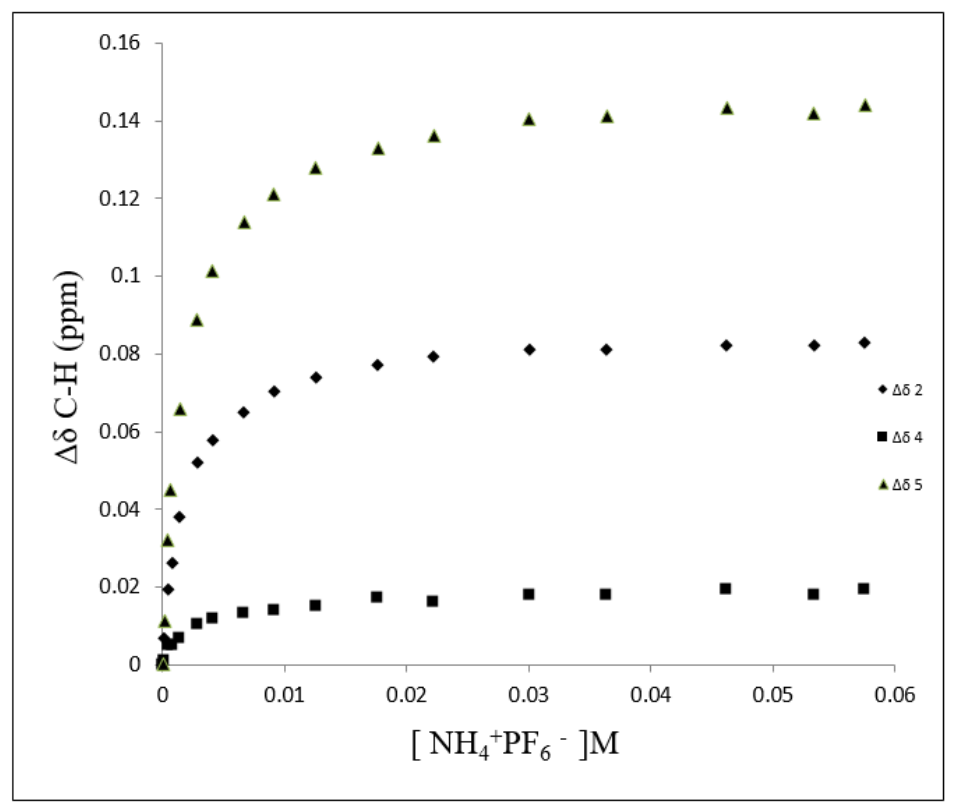

Figure A.5. ${ }^{1} \mathrm{H}-\mathrm{NMR}$ titration plot of 1 with $\mathrm{NH}_{4}{ }^{+} \mathrm{PF}_{6}{ }^{-}$in $\mathrm{CD}_{3} \mathrm{OD}$. The concentration of 1 was kept constant at $2 \mathrm{mM}$. 


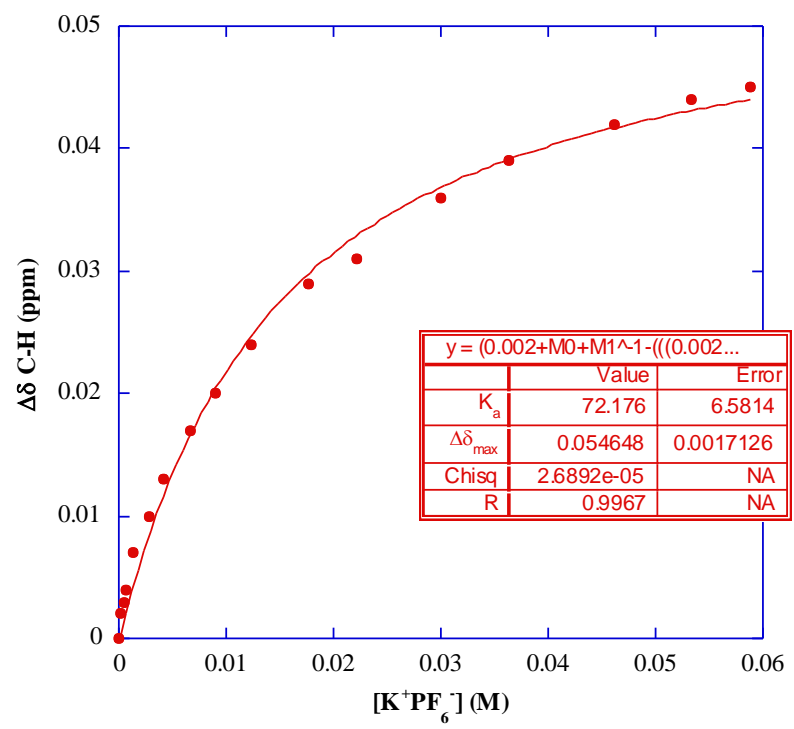

Figure A.6. ${ }^{1} \mathrm{H}-\mathrm{NMR}$ titration plot of 1 with $\mathrm{K}^{+} \mathrm{PF}_{6}{ }^{-}$in $\mathrm{CD}_{3} \mathrm{OD}$. The concentration of $\mathbf{1}$ was kept constant at $2 \mathrm{mM}$.

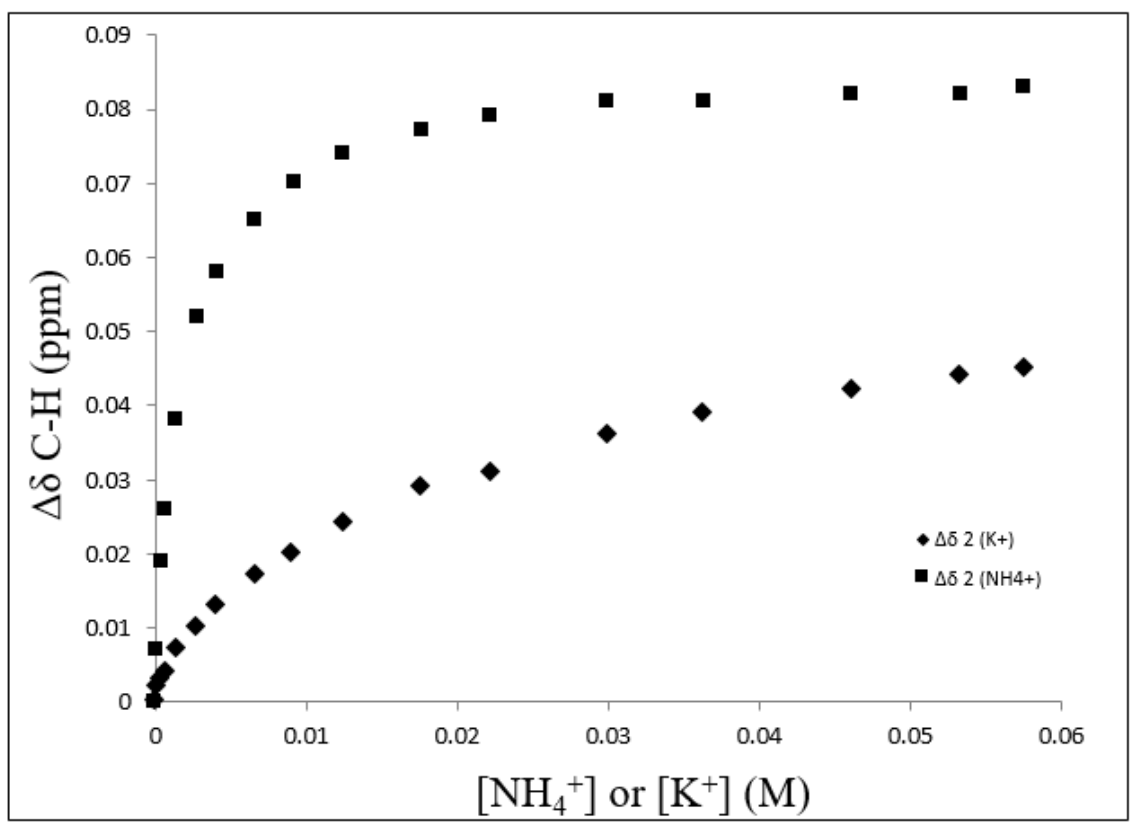

Figure A.7. ${ }^{1} \mathrm{H}-\mathrm{NMR}$ titration plot showing the binding of $\mathrm{NH}_{4}{ }^{+}$over $\mathrm{K}^{+}$by $\mathbf{1}$ in $\mathrm{CD}_{3} \mathrm{OD}$ 


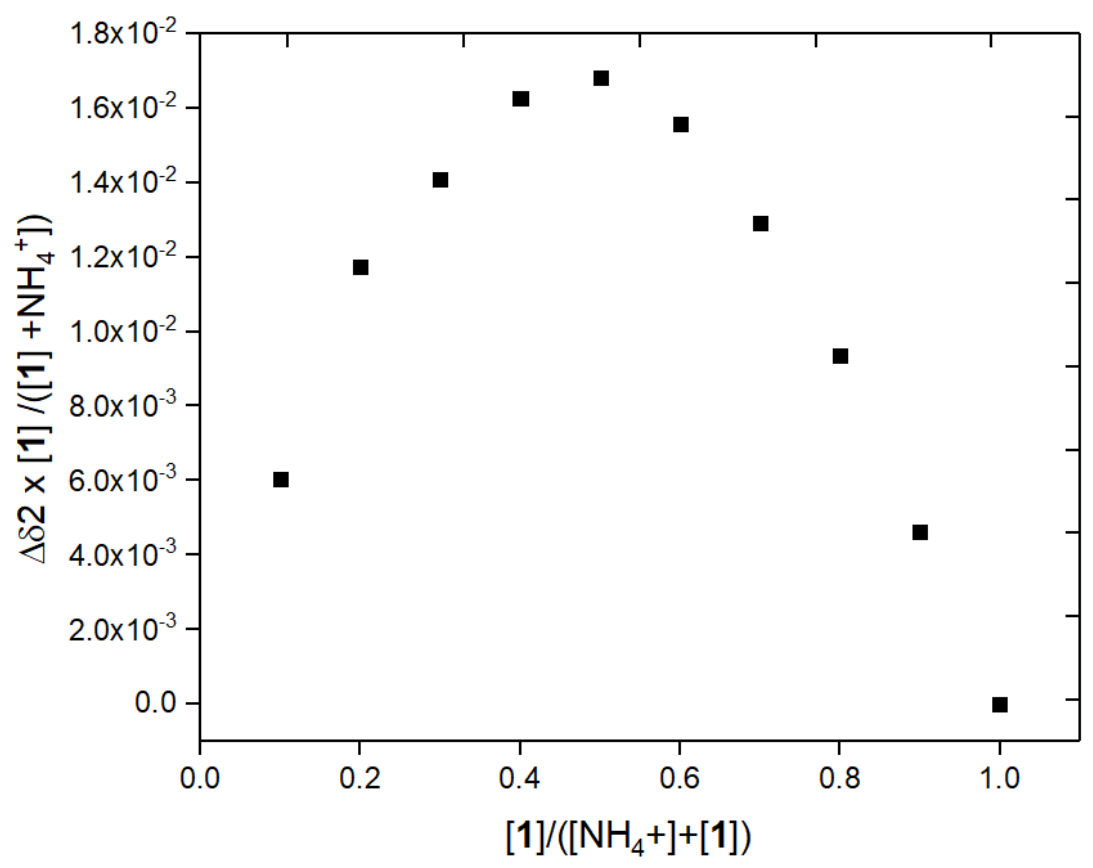

Figure A.8. Job plot of $\mathbf{1}$ with $\mathrm{NH}_{4}{ }^{+} \mathrm{PF}_{6}{ }^{-}$in $\mathrm{CD}_{3} \mathrm{OD}$. $0.002 \mathrm{M}$ Stock solutions of $\mathbf{1}$ and $\mathrm{NH}_{4}{ }^{+} \mathrm{PF}_{6}{ }^{-}$were used.

In an effort to obtain single crystals of the complex between 1,3,5-Tris(4-methyl-2oxazolinylmethyl)-2,4,6-triethylbenzene (1) and $\mathrm{NH}_{4} \mathrm{PF}_{6}$, we instead obtained RGR534_a, a doubly deprotonated 2,4,6-triethylbenzene-1,3,5-triacetic acid bound to an ammonium cation at the carboxylate end and a protonated alaninol (protonated at the amine nitrogen), forming two H-bonds to the carboxylate oxygen atoms (Figure A.9). The triacetic acid is doubly deprotonated to compensate the two positive charges imposed by the ammonium and alaninol. The strong interaction between the cations and the acid is indicated by the numerous strong H-bonds as shown in table A1. The ammonium cation is also bound by a cation- $\pi$ interaction, (N-H... $\pi$-centroid 3.150(6) $\AA$ ) (Figure A.9) 

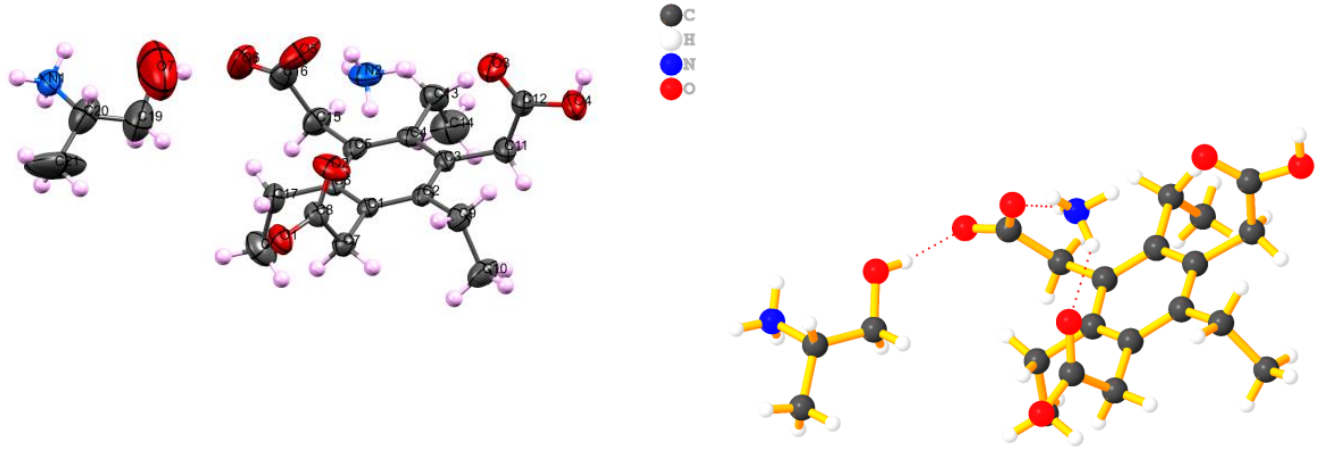

Figure A.9: 50\% probability ORTEP Thermoellipsoid (left) and PLATO (right) representation of the crystal structure of 2,4,6-triethylbenzene-1,3,5-triacetic acid, with $\mathrm{NH}_{4}{ }^{+}$and alaninol, showing the $\mathrm{NH}_{4}{ }^{+}$binding to tricarboxylic acid interactions via $\mathrm{H}-$ bonding and cation- $\pi$ interactions.

As it can be seen in Figure A.10, a supramolecular network of alternate hydrophilic and hydrophobic layers is formed through a series of hydrogen bonds, cation- $\pi$ interactions and hydrophobic interactions.

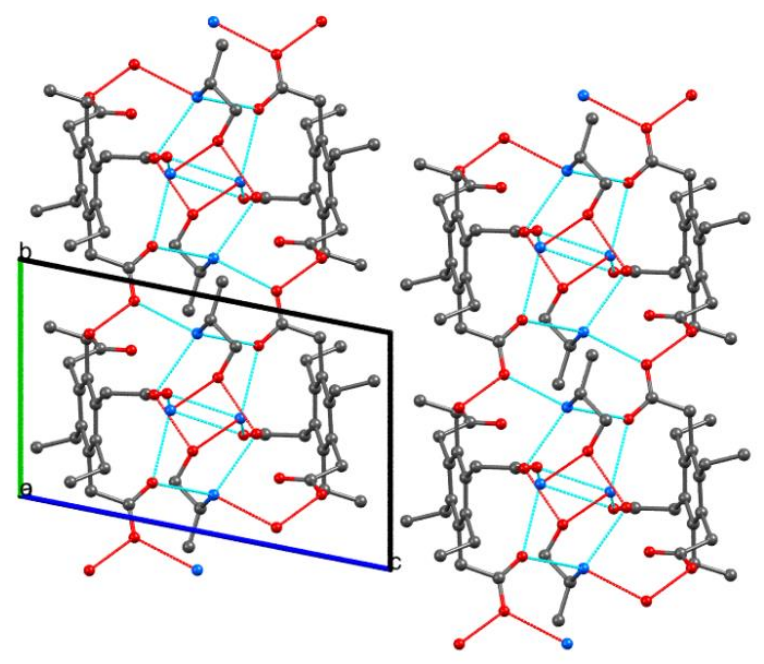

Figure A.10: Packing diagram of the crystal structure of the alaninol/ $/ \mathrm{NH}_{4}{ }^{+} / 2,4,6-$ triethylbenzene-1,3,5-triacetic acid, showing alternate layers of hydrophilic H-bonding networks and organic networks stabilized by hydrophobic interactions and crystal packing 
Table A.1: Hydrogen Bond information for RGR534_a.

\begin{tabular}{|c|c|}
\hline Compound & RGR534_a \\
\hline Formula & $\mathrm{C}_{21} \mathrm{H}_{36} \mathrm{~N}_{2} \mathrm{O}_{7}$ \\
\hline$D_{\text {calc. }} / \mathrm{g} \mathrm{cm}^{-3}$ & 1.239 \\
\hline$\mu / \mathrm{mm}^{-1}$ & 0.092 \\
\hline Formula Weight & 428.52 \\
\hline Color & colorless \\
\hline Shape & plate \\
\hline Size $/ \mathrm{mm}^{3}$ & $0.14 \times 0.12 \times 0.02$ \\
\hline$T / \mathrm{K}$ & $298(2)$ \\
\hline Crystal System & triclinic \\
\hline Space Group & $\mathrm{P}-1$ \\
\hline$a / \AA$ & $9.4528(5)$ \\
\hline$b / \AA$ & $9.9700(6)$ \\
\hline$c / \AA$ & $14.0679(8)$ \\
\hline$\alpha /^{\circ}$ & $99.453(2)$ \\
\hline$\beta /^{\circ}$ & $90.982(2)$ \\
\hline$\left.\gamma\right|^{\circ}$ & $117.938(2)$ \\
\hline $\mathrm{V} / \AA^{3}$ & $1148.64(11)$ \\
\hline$Z$ & 2 \\
\hline$Z^{\prime}$ & 1 \\
\hline Wavelength/Å & 0.710760 \\
\hline Radiation type & $\mathrm{MoK}_{\alpha}$ \\
\hline$\Theta_{\min } /^{\circ}$ & 2.953 \\
\hline$\Theta_{\max } /^{\circ}$ & 26.421 \\
\hline Measured Refl. & 25721 \\
\hline Independent Refl. & 4710 \\
\hline Reflections Used & 2751 \\
\hline$R_{\text {int }}$ & 0.0592 \\
\hline Parameters & 294 \\
\hline Restraints & 1 \\
\hline Largest Peak & 0.689 \\
\hline Deepest Hole & -0.465 \\
\hline GooF & 1.038 \\
\hline$w R_{2}$ (all data) & 0.2844 \\
\hline$w R_{2}$ & 0.2494 \\
\hline$R_{1}$ (all data) & 0.1753 \\
\hline$R_{1}$ & 0.1081 \\
\hline
\end{tabular}




\begin{tabular}{lllccrl}
\hline $\mathbf{D}$ & $\mathbf{H}$ & $\mathbf{A}$ & $\mathbf{d}(\mathbf{D}-\mathbf{H}) / \AA$ & $\mathbf{d}(\mathbf{H}-\mathbf{A}) / \mathbf{A}$ & $\mathbf{d}(\mathbf{D}-\mathbf{A}) / \AA$ & $\mathbf{D}-\mathbf{H}-\mathbf{A} / \mathbf{d e g}$ \\
\hline $\mathrm{O} 4$ & $\mathrm{H} 4$ & $01^{1}$ & 0.82 & 1.80 & $2.594(5)$ & 163.4 \\
$\mathrm{~N} 2$ & $\mathrm{H} 2 \mathrm{~A}$ & $\mathrm{O} 2$ & $0.91(8)$ & $2.08(7)$ & $2.839(7)$ & $140(6)$ \\
$\mathrm{N} 2$ & $\mathrm{H} 2 \mathrm{D}$ & $\mathrm{O} 5$ & $0.81(2)$ & $2.02(2)$ & $2.823(9)$ & $172(7)$ \\
$\mathrm{N} 1$ & $\mathrm{H} 1 \mathrm{C}$ & $\mathrm{O1}^{2}$ & 0.89 & 1.911 & $2.747(5)$ & 155.7 \\
$\mathrm{~N} 1$ & $\mathrm{H} 1 \mathrm{~B}$ & $\mathrm{O1}^{3}$ & 0.889 & 2.013 & $2.827(7)$ &
\end{tabular}

\section{A.3. EXPERIMENTAL SECTION}

\section{A.3.1. Material and Methods}

All materials (purchased from Aldrich Chemical Co., ACROS Organics, or Alfa Aesar) were standard reagent grade and were used without further purification. ${ }^{1} \mathrm{H}$ and ${ }^{13} \mathrm{C}$ NMR spectra were recorded on a 400 Bruker NMR spectrometer and were referenced, using the residual solvent resonances. All chemical shifts, $\delta$, are reported in ppm.

\section{A.3.2. Synthesis of 1,3,5- Tris (4-methyl-2- oxazolinylmethyl)-2,4,6 triethylbenzene.(1)}

$380 \mathrm{mg}$ of 2,4,6-triethylbenzene-1,3,5-triacetic acid was dissolved in $40 \mathrm{~mL}$ of anhydrous toluene and the system was purged with nitrogen and solution heated to reflux. After $5 \mathrm{mins}$, a solution of $240 \mathrm{mg}$ of alaninol in $5 \mathrm{~mL}$ toluene was added. The solution was left to reflux for $48 \mathrm{~h}$. After $48 \mathrm{~h}$, the reaction was allowed to cool and the solvent was evaporated to give a cream colored solid $(0.49 \mathrm{~g}, 1.1 \mathrm{mmol}, 40 \%) .{ }^{1} \mathrm{H}$ NMR $\left(\mathrm{CH}_{3} \mathrm{OD}\right) \delta$, $1.13(9 \mathrm{H}, \mathrm{t}, J=7.6 \mathrm{~Hz}), 1.16(9 \mathrm{H}, \mathrm{d}), 2.59(6 \mathrm{H}, \mathrm{q}, J=7.6 \mathrm{~Hz}), 3.73(1 \mathrm{H}, \mathrm{m}), 3.45(3 \mathrm{H}, \mathrm{d}$ ), $3.56(3 \mathrm{H}, \mathrm{d}), 3.66(3 \mathrm{H}, \mathrm{s})$.

\section{A.3.3. Fluorescence Spectroscopy}

The fluorescence emission was measured using an excitation wavelength of 272 $\mathrm{nm}$, a measurement increment of $0.5 \mathrm{~nm}$, and integration time of $0.1 \mathrm{~s}$, excitation slit width 
of $10 \mathrm{~nm}$ and emission slit width of $5 \mathrm{~nm}$. Experiments were run using solutions of $\left(5 \times 10^{-}\right.$ ${ }^{5} \mathrm{M}$ ) in $\mathrm{CH}_{3} \mathrm{OH} / \mathrm{CH}_{2} \mathrm{Cl}_{2}$ 1:10 (solution A) which were titrated with solutions of $\mathrm{NH}_{4}{ }^{+} \mathrm{PF}_{6}{ }^{-}$ $\left(5 \times 10^{-3} \mathrm{M}\right)$ and $\left(5 \times 10^{-5} \mathrm{M}\right)$ in $\mathrm{CH}_{3} \mathrm{OH} / \mathrm{CH}_{2} \mathrm{Cl}_{2} 1: 10$ (solution B). In a typical experiment, $2.5 \mathrm{~mL}$ of solution A was added to the fluorescence cuvette and solution B was added in increments until a total of $1000 \mu \mathrm{L}$ was added. The fluorescence intensity at $298 \mathrm{~nm}$ was monitored and recorded. The same procedure was repeated for $\mathrm{K}^{+} \mathrm{PF}_{6}{ }^{-}$and $\mathrm{Na}^{+} \mathrm{PF}_{6}{ }^{-}$.

\section{A.3.4. ${ }^{1} \mathrm{H}-\mathrm{NMR}$ Titrations of 1 with $\mathrm{NH}_{4}{ }^{+} \mathrm{PF}_{6}{ }^{-}$and $\mathrm{K}^{+} \mathrm{PF}_{6}$.}

The association constants for the formation of cation-receptor complexes were determined by titration of solutions of $1\left(2 \times 10^{-3} \mathrm{M}\right)$ in $\mathrm{CD}_{3} \mathrm{OD}$ (solution $\mathrm{A}$ ) with $1 \times 10^{-1}$ M of $\mathrm{NH}_{4}{ }^{+} \mathrm{PF}_{6}{ }^{-}$(solution B). Solution B was prepared by dilutions with solution A, thus keeping a constant concentration of $\mathbf{1}$ upon titration of solution A with solution B. In a typical experiment, solution A $(0.700 \mathrm{~mL})$ was placed in an NMR tube. Solution B was added in increments until a total of $950 \mu \mathrm{L}$ was added. The chemical shift changes were monitored, with the results plotted and fitted to the 1:1 binding isotherm (Eq.1) using nonlinear regression analysis:

$$
\left.\Delta \delta=\delta_{\text {obs }}-\delta_{2}=\left([\mathbf{R}]_{\mathrm{t}}+\left[\mathrm{X}^{-}\right]_{\mathrm{t}}+\mathrm{K}_{\mathrm{a}}^{-1}-\left(\left(\left([\mathbf{R}]_{\mathrm{t}}+\left[\mathrm{X}^{-}\right]_{\mathrm{t}}+\mathrm{K}_{\mathrm{a}}^{-1}\right)^{2}-4\left[\mathrm{X}^{-}\right]_{\mathrm{t}}[\mathbf{R}]_{\mathrm{t}}\right)^{1 / 2}\right)\right) \Delta \delta_{\max }\right)
$$

$/\left(2[\mathbf{R}]_{\mathrm{t}}\right)$

\section{A.3.5. Continuous Variation Method (Jobs plots):}

Stock solutions of the receptors $1(0.002 \mathrm{M})$ and $\mathrm{NH}_{4}{ }^{+} \mathrm{PF}_{6}^{-}(0.002 \mathrm{M})$ in $\mathrm{CD}_{3} \mathrm{OD}$ were prepared. Ten NMR tubes were filled with $500 \mu 1$ solutions of the host and guest in the following volume ratios (in $\mu 1) .500: 0,450: 50,400: 100,350: 150,300: 200,250: 250,200$ :

300,150:350, 100:400, 50:450. ${ }^{1} \mathrm{H}-\mathrm{NMR}$ spectra were recorded and jobs plot was obtained 
by plotting against $[\mathbf{L}] /\left(\left[\mathrm{NH}_{4}+\right]+[\mathbf{L}]\right)$ (where $\mathbf{L}$ is receptor $\left.\mathbf{1}\right)$. Jobs plot curve maxima at mol. fraction of 0.5 were observed for host:guest indicating a 1:1 complex stoichiometry.

\section{A.4. Conclusion}

We have synthesized $\quad 1,3,5-\quad$ Tris(4-methyl-2- oxazolinylmethyl)-2,4,6triethylbenzene.(1) that is selective for $\mathrm{NH}_{4}{ }^{+}$over $\mathrm{K}^{+}$. The binding constants by NMR titrations reveal remarkable binding strength and selectivity for $\mathrm{NH}_{4}{ }^{+}$over $\mathrm{K}^{+}$for $\mathbf{1}$.

\section{A.5. References}

1. Munshi, M. K.; Gade S. M.; Rane V. H. ; Kelkar A. A. : RSC Advances, 2014, 4, 32127-32133.

2. Bianchi, A; Browman-James, K; Garcia-Espania, E. Supramolecular Chemistry of Anions, Wiley, New York, 1997.

3. Evans, N. H.; Rahman, H.; Davis, J. J.; Beer, P. D. Anal. Bioanal. Chem. 2012, 402, $1739-1748$.

4. Cafeo, G.; Gattuso, G.; Kohnke,F. H.; Notti, A.; Occhipinti, S.; Pappalardo, S.; Parisi, M. F Angew. Chem. Int. Ed. 2002, 41, 2122-2126.

5. Mc Connell, A.J.; Beer, P.D. Angew. Chem. Int. Ed., 2012, 51, 5050-5061.

6. Kim, S. K.; Sessler, J. L. Chem. Soc. Rev, 2010, 39, 3784-3809.

7. Cort,A. D. Supramolecular chemistry: From Molecules to Nanomaterials, Wiley, New York, 2012.

8. Ahn, K.H., Kim, S.G., Jung, J., Kim, K.H., Kim, J., Chin, J., \& Kim, K. Chem. Lett., 2000, 29, 170-171.

9. Wanichacheva, N., Kumsorn, P., Sangsuwan, R., Kamkaew, A., Lee, V. S., \& Grudpan, K. Tetrahedron. Lett., 2011, 52, 6133-6136.

10. Bhatt, K. D., Gupte, H. S., Makwana, B. A., Vyas, D. J., Maity, D., \& Jain, V. K. J. Fluoresc., 2012, 22, 1493-1500.

11. Currie, R. Spectroscopic, Electrochemical and Mass Spectrometric Investigation of 
Anion Binding by Tripodal Molecular Receptors. Florida International University, 2005 .

12. Currie, R., Pau A., Espetia O. D., and Kavallieratos K., Anion Binding Properties and Extraction effects of Fluorescent Dansylamide Receptors derived from Tris(2aminoethyl)amine and 1,3,5-Tris(aminomethyl)-2,4,6-triethylbenzene. Manuscript in preparation.

13. Caygill, J. S., et. al., Current Trends in Explosive Detection Techniques. Talanta 2012, 15 . 
VITA

\section{TOSIN MOBOLAJI JONAH}

Born in Ile-Ife, Nigeria

Fall 2008

B.S. in Biochemistry

Ladoke Akintola University, Ogbomosho, Oyo State, Nigeria.

Fall 2016

M.Sc. in Forensic Science

Florida International University, Miami, FL, USA

Fall 2017

PhD Candidate (expected graduation Dec 2017)

Florida International University, Miami, FL, USA

Dissertation title: SELECTIVE SENSING OF IONS AND ION

PAIRS OF ENVIRONMENTAL AND FORENSIC

SIGNIFICANCE

Advisor: Konstantinos Kavallieratos, Ph.D.

2016

Doctoral Acquisition Award

Florida International University, Miami, FL

\section{PUBLICATIONS AND PRESENTATIONS}

Tosin M. Jonah, Logesh Mathivathanan, Raphael G. Raptis, Konstantinos Kavallieratos. Remarkably Selective $\mathrm{NH}_{4}{ }^{+}$Binding and Fluorescence Sensing by Tripodal Tris(pyrazolyl) Receptors Derived from 1,3,5-Triethylbenzene; Structural and Theoretical Insights on the Role of Ion Pairing, New Journal of Chemistry, 2017, 41, 14835-14838.

Konstantinos Kavallieratos, Evgen V. Govor, Megan Twomey, Vasileios A. Anagnostopoulos, Tosin M. Jonah, Alexander N. Morozov, Alexander M. Mebel, Raphael G. Raptis: Tripodal Sulfonamide and Pyrazolyl Ligands for Extraction and Sensing of Lanthanides and Actinides. Proceedings of GLOBAL 2017 September 24-29, 2017 - Seoul (Korea).

Tosin M. Jonah, Logesh Mathivathanan, Shambhu Kandel, Raphael G. Raptis, Konstantinos Kavallieratos: Tripodal pyrazole ligands and analogs for selective ammonium and actinide extraction and sensing. 253 ${ }^{\text {rd }}$ ACS National Meeting \& Exposition, San Francisco, California, April, 2017. 
Tosin M. Jonah; Richild Currie; Konstantinos Kavallieratos: Towards selective ion-pair sensing based on anion and cation complexation and co-extraction: Dual-host combinations of fluorescent sensors for ammonium and nitrate. 251st ACS National Meeting \& Exposition, San Diego, California, March, 2016.

Konstantinos Kavallieratos, Evgen V. Govor, Tosin M. Jonah, Shambhu Kandel, Raphael G. Raptis: Tripodal Sulfonamides and Pyrazoles for An(III) Coordination and Extraction. Separation Science and Technology Conference, Gatlinburg, TN, October, 2016

Tosin M. Jonah; Cynthia Cortes; Richild Currie; Konstantinos Kavallieratos: Dual-host combinations of fluorescent sensors for ammonium and nitrate based on anion and cation complexation and co-extraction for selective ion-pair sensing. Florida Annual Meeting and Exposition, May, 2016.

Jessica S. Duchene; Amanda M. Howett; Tosin M. Jonah; Konstantinos Kavallieratos; Towards a dual-host approach for sensing of ammonium nitrate and other explosive salts: Intermolecular interactions between the dansyl fluorophore and anions lead to fluorescence enhancements. $247^{\text {th }}$ National spring meeting of American Chemical Society, Vol, 247, 2014 